National Water-Quality Assessment Project

\title{
Groundwater-Quality and Select Quality-Control Data from the National Water-Quality Assessment Project, January 2017 through December 2019
}

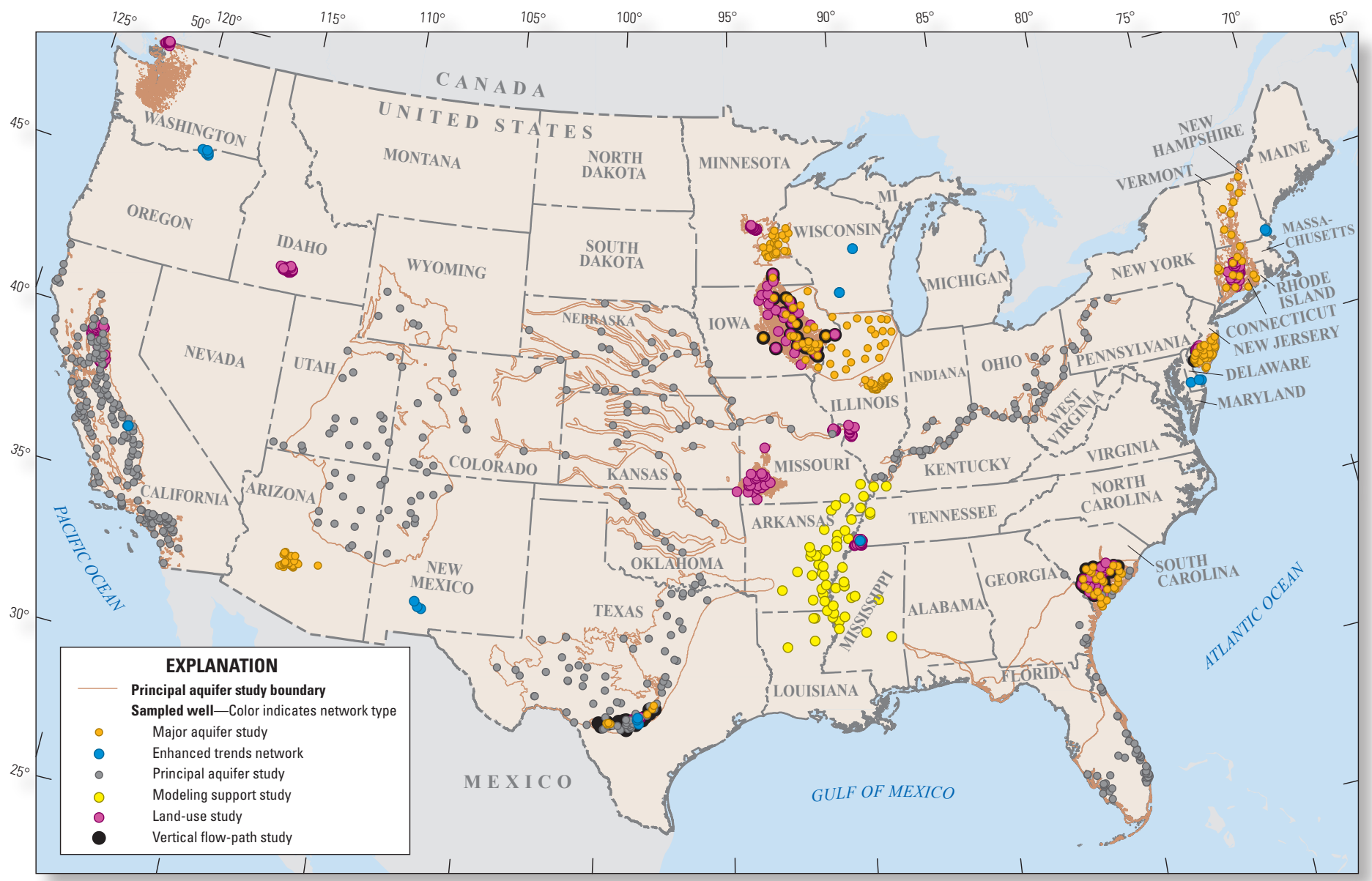

Data Series 1136 



\section{Groundwater-Quality and Select Quality-Control Data from the National Water-Quality Assessment Project, January 2017 through December 2019}

By James A. Kingsbury, Laura M. Bexfield, Terri Arnold, MaryLynn Musgrove, Melinda L. Erickson, James R. Degnan, Anthony J. Tesoriero, Bruce D. Lindsey, and Kenneth Belitz

National Water-Quality Assessment Project

Data Series 1136 


\section{U.S. Geological Survey, Reston, Virginia: 2021}

For more information on the USGS - the Federal source for science about the Earth, its natural and living resources, natural hazards, and the environment—visit https://www.usgs.gov or call 1-888-ASK-USGS.

For an overview of USGS information products, including maps, imagery, and publications, visit https://store.usgs.gov/.

Any use of trade, firm, or product names is for descriptive purposes only and does not imply endorsement by the U.S. Government.

Although this information product, for the most part, is in the public domain, it also may contain copyrighted materials as noted in the text. Permission to reproduce copyrighted items must be secured from the copyright owner.

Suggested citation:

Kingsbury, J.A., Bexfield, L.M., Arnold, T., Musgrove, M., Erickson, M.L., Degnan, J.R., Tesoriero, A.J., Lindsey, B.D., and Belitz, K., 2021, Groundwater-quality and select quality-control data from the National Water-Quality Assessment Project, January 2017 through December 2019: U.S. Geological Survey Data Series 1136, 97 p., https://doi.org/ 10.3133/ds1136.

Associated data for this publication:

Kingsbury, J.A., Sharpe, J.B., Bexfield, L.M., Arnold, T.L., Musgrove, M., Erickson, M.L., Degnan, J.R., Tesoriero, A.J., Lindsey, B.D., and Belitz, K., 2020, Datasets of groundwater-quality and select quality-control data from the National Water-Quality Assessment Project, January 2017 through December 2019 (ver. 1.1, January 2021): U.S. Geological Survey data release, https://doi.org/10.5066/PgXATXV1.

U.S. Geological Survey, 2020, USGS water data for the Nation: U.S. Geological Survey National Water Information System database, https://doi.org/10.5066/F7P55KJN.

ISSN 2327-638X (online) 


\section{Foreword}

Sustaining the quality of the Nation's water resources and the health of our diverse ecosystems depends on the availability of sound water-resources data and information to develop effective, science-based policies. Effective management of water resources also brings more certainty and efficiency to important economic sectors. Taken together, these actions lead to immediate and long-term economic, social, and environmental benefits that make a difference to the lives of the almost 400 million people projected to live in the United States by 2050.

In 1991, Congress established the National Water-Quality Assessment (NAWQA) Project to address where, when, why, and how the Nation's water quality has changed, or is likely to change in the future, in response to human activities and natural factors. Since then, NAWOA has been a leading source of scientific data and knowledge used by national, regional, State, and local agencies to develop science-based policies and management strategies to improve and protect water resources used for drinking water, recreation, irrigation, energy development, and ecosystem needs (https://water.usgs.gov/nawqa/applications/). Plans for the third decade of NAWQA (2013-23) address priority water-quality issues and science needs identified by NAWQA stakeholders, such as the Advisory Committee on Water Information and the National Research Council, and are designed to meet increasing challenges related to population growth, increasing needs for clean water, and changing land-use and weather patterns.

NAWQA is assessing the quality of groundwater used for public and domestic drinking-water supply. NAWQA obtains samples from public-supply wells, domestic wells, and shallow monitoring wells and analyzes those samples for a large number of chemical constituents. These data are used to assess the suitability of the resource for human consumption, as well as to evaluate changes in groundwater quality over a variety of time scales. Groundwater quality also is assessed at multiple scales: locally, regionally, and nationally. Groundwater-quality data collected by the NAWQA Project during each year are published in annual data series reports. This report, the fifth in the series, combines groundwater-quality data collected at 983 sites to provide a summary of groundwater quality in selected aquifers across the Nation during the sampling period. All NAWQA reports are available online at https://water.usgs.gov/nawqa/bib/.

We hope this publication will provide you with insights and information to meet your waterresource needs and will foster increased citizen awareness and involvement in the protection and restoration of our Nation's waters. The information in this report is intended primarily for those interested or involved in resource management and protection, conservation, regulation, and policymaking at the regional and national levels.

Dr. Donald W. Cline Associate Director for Water

U.S. Geological Survey 



\section{Contents}

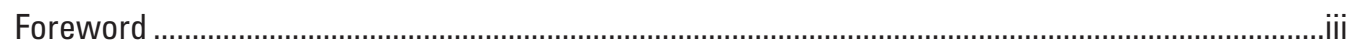

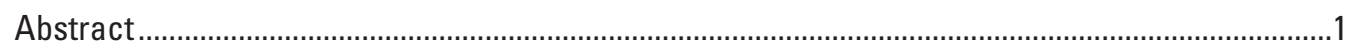

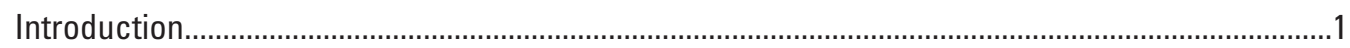

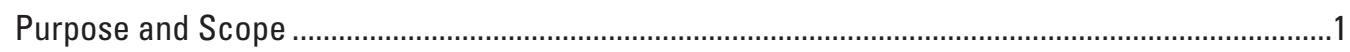

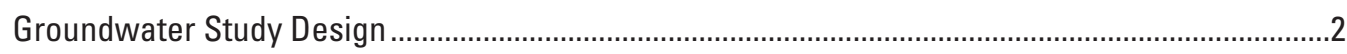

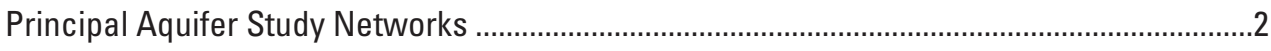

Colorado Plateaus Principal Aquifer Study Network (coplpas1).....................................4

Edwards-Trinity Aquifer System Principal Aquifer Study Network (edtrpas1).................4

Stream-Valley Aquifers Principal Aquifer Study Network 1 (strvpas1) ..........................12

Stream-Valley Aquifers Principal Aquifer Study Network 2 (strvpas2) ...........................12

Surficial Aquifer System Principal Aquifer Study Network (surfpas1)...........................13

California Coastal Basin Aquifers Principal Aquifer Study Network (cacbpas1) ...........13

Central Valley Aquifer System Principal Aquifer Study Network (cvalpas1)..................14

Decadal Trends Networks—Land-Use Study Networks ........................................................14

Connecticut, Housatonic, and Thames River Basins Urban Land-Use Study Network (connlusrc1) .....................................................................................14

Eastern lowa Basins Agricultural Land-Use Study Network (eiwaluscr1) .....................27

Long Island-New Jersey Coastal Drainages Urban Land-Use Study Network

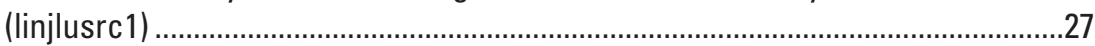

Mississippi Embayment Urban Land-Use Study Network (miselusrc 1) ..........................27

Ozark Plateaus Agricultural Land-Use Study Network (ozrklusag2a) .............................27

Puget Sound Drainages Agricultural Land-Use Study Network (pugtluscr1) ................28

Sacramento River Basin Agricultural Land-Use Study Network (sacrluscr1) ...............28

Sacramento River Basin Urban Land-Use Study Network (sacrlusrc1) .........................28

Santee River Basin and Coastal Drainages Agricultural Land-Use Study

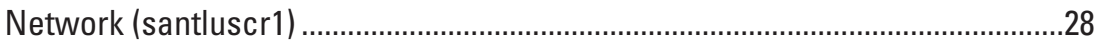

South-Central Texas Urban Land-Use Study Network (sctxlusrc1) ..............................28

Upper Mississippi River Basin Agricultural Land-Use Study Network (umisluscr1) ....29

Upper Snake River Basin Agricultural Land-Use Study Network (usnkluscr3) ..............29

Decadal Trends Networks — Major Aquifer Study Networks..............................................2

Central Arizona Basins Major Aquifer Study Network (cazbsus1a) ..............................29

Connecticut, Housatonic, and Thames River Basins Major Aquifer Study Network (connsus2) ..........................................................................................3

Eastern lowa Basins Major Aquifer Study Network (eiwasus2) ......................................39

Long Island-New Jersey Coastal Drainages Major Aquifer Study Network

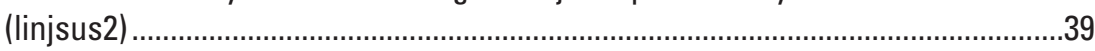

Lower Illinois River Basin Major Aquifer Study Network (lirbsus1)...............................39

Santee River Basin and Coastal Drainages Major Aquifer Study Network

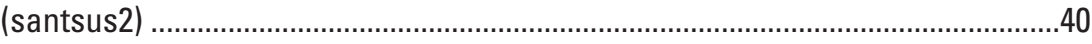

South-Central Texas Major Aquifer Study Network (sctxsus1) ....................................40

Upper Illinois River Basin Major Aquifer Study Network (uirbsus3)................................40

Upper Mississippi River Basin Major Aquifer Study Network (umissus3)......................40

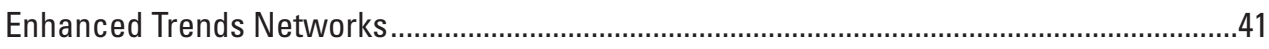

Columbia Plateau Enhanced Trends Network (clptetn1) .................................................41 
Central Valley Enhanced Trends Network (cvaletn1) ....................................................44

Rio Grande Aquifer System Enhanced Trends Network (rgaqetn1)...............................44

Edwards-Trinity Aquifer System Enhanced Trends Network (edtretn1).........................44

Glacial Aquifer System Enhanced Trends Network (glacetn1)........................................4

Mississippi Embayment Aquifer System Enhanced Trends Network (metxetn1) ...........44

Northern Atlantic Coastal Plain Enhanced Trends Network (nacpetn1).........................45

New England Crystalline-Rock and Glacial Aquifer System Enhanced Trends

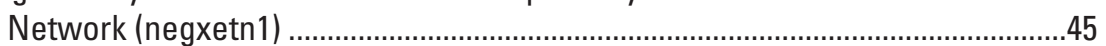

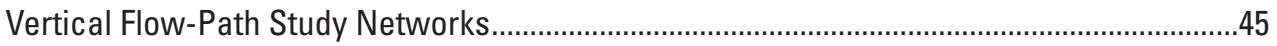

Edwards-Trinity Aquifer System Vertical Flow-Path Study Network (edtrvfps1)............45

Floridan and Surficial Aquifer System Vertical Flow-Path Study Network

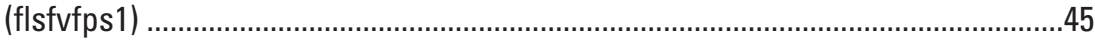

Glacial Aquifer System Vertical Flow-Path Study Network (glacvfps2)........................50

Northern Atlantic Coastal Plain Aquifer System Vertical Flow-Path Study

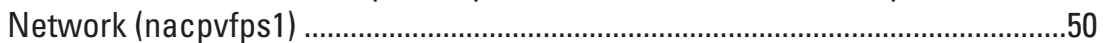

Modeling Support Study Networks .......................................................................................50

Mississippi Embayment Aquifer System Modeling Support Study Network

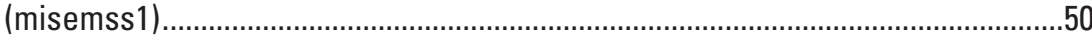

Mississippi River Valley Alluvial Aquifer Modeling Support Study Networks

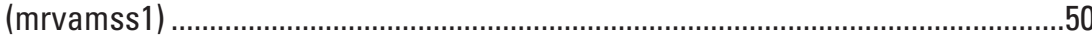

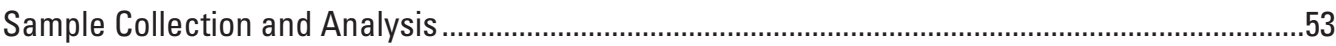

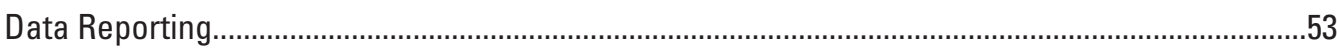

Quality-Assurance and Quality-Control Methods ………............................................................5

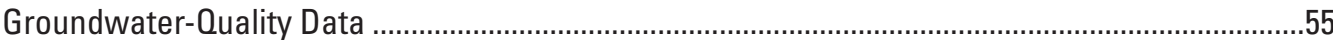

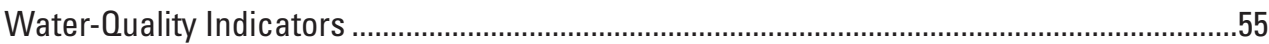

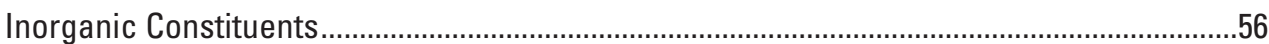

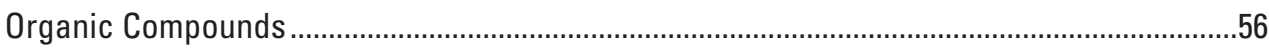

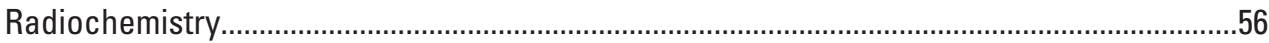

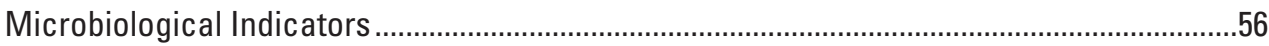

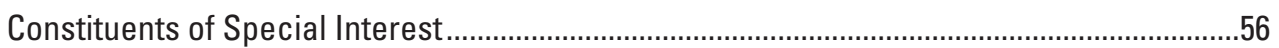

Summary

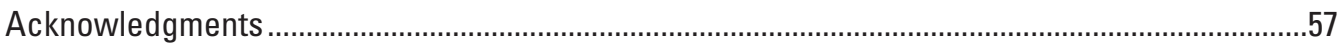

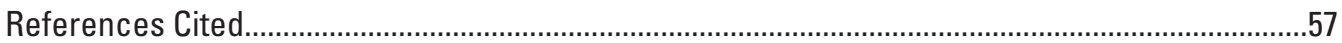

Appendix 1. Information Contained in Previous Reports in This Series.......................................64

Appendix 2. Well Depth and Open Interval by Study Network .....................................................65

Appendix 3. Well Identification Numbers and Reports Containing Sample Results for Wells in the California Coastal Basin Aquifers and Central Valley Aquifer System

Principal Aquifer Study Networks ...................................................................................

Appendix 4. High-Frequency Data from Enhanced Trends Networks............................................71

Appendix 5. Quality-Control Data and Analysis ………................................................................. 


\section{Figures}

1. Map showing groundwater study networks and wells sampled as part of the U.S. Geological Survey National Water-Quality Assessment Project for which water-quality data are included in this report. 3

2. Map showing study area and wells sampled as part of the Colorado Plateaus aquifers principal aquifer study network for the U.S. Geological Survey National Water-Quality Assessment Project...

3. Map showing study area and wells sampled as part of the Edwards-Trinity aquifer system principal aquifer study network for the U.S. Geological Survey National Water-Quality Assessment Project.

4. Map showing study area and wells sampled as part of the stream-valley aquifers principal aquifer study network 1 for the U.S. Geological Survey National Water-Quality Assessment Project.

5. Map showing study area and wells sampled as part of the stream-valley aquifers principal aquifer study network 2 for the U.S. Geological Survey National Water-Quality Assessment Project.

6. Map showing study area and wells sampled as part of the surficial aquifer system principal aquifer study network for the U.S. Geological Survey National Water-Quality Assessment Project

7. Maps showing study area and wells sampled as part of the California Coastal Basin aquifers principal aquifer study network for the U.S. Geological Survey National Water-Quality Assessment Project.

8. Map showing study area and wells sampled as part of the Central Valley aquifer system principal aquifer study network for the U.S. Geological Survey National Water-Quality Assessment Project

9. Map showing study area and wells sampled as part of the Connecticut, Housatonic, and Thames River Basins urban land-use study network near Hartford, Connecticut, for the U.S. Geological Survey National Water-Quality Assessment Project

10. Map showing study area and wells sampled as part of the Eastern lowa Basins agricultural land-use study network for the U.S. Geological Survey National Water-Quality Assessment Project

11. Map showing study area and wells sampled as part of the Long Island-New Jersey coastal drainages urban land-use study network near Glassboro, New Jersey, for the U.S. Geological Survey National Water-Quality Assessment Project ....17

12. Map showing study area and wells sampled as part of the Mississippi Embayment urban land-use study network near Memphis, Tennessee, for the U.S. Geological Survey National Water-Quality Assessment Project.

13. Map showing study area and wells sampled as part of the Ozark Plateaus agricultural land-use study network for the U.S. Geological Survey National Water-Quality Assessment Project

14. Map showing study area and wells sampled as part of the Puget Sound drainages agricultural land-use study network for the U.S. Geological Survey National Water-Quality Assessment Project.

15. Map showing study area and wells sampled as part of the Sacramento River Basin agricultural land-use study network for the U.S. Geological Survey National Water-Quality Assessment Project

16. Map showing study area and wells sampled as part of the Sacramento River Basin urban land-use study network near Sacramento, California, for the U.S. Geological Survey National Water-Quality Assessment Project 
17. Map showing study area and wells sampled as part of the Santee River Basin and coastal drainages agricultural land-use study network for the U.S.

Geological Survey National Water-Quality Assessment Project.

18. Map showing study area and wells sampled as part of the South-Central Texas urban land-use study network near San Antonio, Texas, for the U.S. Geological Survey National Water-Quality Assessment Project.

19. Map showing study area and wells sampled as part of the Upper Mississippi River Basin agricultural land-use study network for the U.S. Geological Survey National Water-Quality Assessment Project.

20. Map showing study area and wells sampled as part of the Upper Snake River Basin aquifer system agricultural land-use study network for the U.S. Geological Survey National Water-Quality Assessment Project. .26

21. Map showing study area and wells sampled as part of the Central Arizona Basins major aquifer study network for the U.S. Geological Survey National Water-Quality Assessment Project

22. Map showing study area and wells sampled as part of the Connecticut, Housatonic, and Thames River Basins major aquifer study network for the U.S. Geological Survey National Water-Quality Assessment Project....

23. Map showing study area and wells sampled as part of the Eastern lowa Basins major aquifer study network for the U.S. Geological Survey National Water-Quality Assessment Project

24. Map showing study area and wells sampled as part of the Long Island-New Jersey coastal drainages major aquifer study network for the U.S. Geological Survey National Water-Quality Assessment Project.

25. Map showing study area and wells sampled as part of the Lower Illinois River Basin major aquifer study network for the U.S. Geological Survey National Water-Quality Assessment Project

26. Map showing study area and wells sampled as part of the Santee River Basin and coastal drainages major aquifer study network for the U.S. Geological Survey National Water-Quality Assessment Project.

27. Map showing study area and wells sampled as part of the South-Central Texas major aquifer study network for the U.S. Geological Survey National Water-Quality Assessment Project

28. Map showing study area and wells sampled as part of the Upper Illinois River Basin major aquifer study network for the U.S. Geological Survey National Water-Quality Assessment Project

29. Map showing study area and wells sampled as part of the Upper Mississippi River Basin major aquifer study network for the U.S. Geological Survey National Water-Quality Assessment Project.

30. Maps showing study areas and wells sampled in the western United States as part of the enhanced trends networks for the U.S. Geological Survey National Water-Quality Assessment Project

31. Maps showing study areas and wells sampled in the eastern United States as part of the enhanced trends networks for the U.S. Geological Survey National Water-Quality Assessment Project

32. Map showing study area and wells sampled as part of the Edwards-Trinity aquifer system vertical flow-path study network for the U.S. Geological Survey National Water-Quality Assessment Project.

33. Map showing study area and wells sampled as part of the Floridan and surficial aquifer system vertical flow-path study network for the U.S. Geological Survey National Water-Quality Assessment Project. 
34. Map showing study area and wells sampled as part of the glacial aquifer system vertical flow-path study network for the U.S. Geological Survey

National Water-Quality Assessment Project

35. Map showing study area and wells sampled as part of the Northern Atlantic Coastal Plain aquifer system vertical flow-path study network for the U.S.

Geological Survey National Water-Quality Assessment Project

36. Map showing study area and wells sampled as part of the Mississippi Embayment aquifer system modeling support study network for the U.S. Geological Survey National Water-Quality Assessment Project

37. Map showing study area and wells sampled as part of the Mississippi River Valley alluvial aquifer modeling support study network for the U.S. Geological Survey National Water-Quality Assessment Project.

\section{Conversion Factors}

U.S. customary units to International System of Units

\begin{tabular}{|c|c|c|}
\hline Multiply & By & To obtain \\
\hline \multicolumn{3}{|c|}{ Length } \\
\hline foot $(\mathrm{ft})$ & 0.3048 & meter $(\mathrm{m})$ \\
\hline mile (mi) & 1.609 & kilometer $(\mathrm{km})$ \\
\hline \multicolumn{3}{|c|}{ Area } \\
\hline square mile $\left(\mathrm{mi}^{2}\right)$ & 2.590 & square kilometer $\left(\mathrm{km}^{2}\right)$ \\
\hline \multicolumn{3}{|c|}{ Flow rate } \\
\hline foot per day (ft/d) & 0.3048 & meter per day $(\mathrm{m} / \mathrm{d})$ \\
\hline cubic foot per second $(\mathrm{ft} 3 / \mathrm{s})$ & 0.02832 & cubic meter per second $\left(\mathrm{m}^{3} / \mathrm{s}\right)$ \\
\hline gallon per minute (gal/min) & 0.06309 & liter per second $(\mathrm{L} / \mathrm{s})$ \\
\hline million gallons per day (Mgal/d) & 0.04381 & cubic meter per second $\left(\mathrm{m}^{3} / \mathrm{s}\right)$ \\
\hline \multicolumn{3}{|c|}{ Radioactivity } \\
\hline picocurie per liter $(\mathrm{pCi} / \mathrm{L})$ & 0.037 & becquerel per liter $(\mathrm{Bq} / \mathrm{L})$ \\
\hline
\end{tabular}

International System of Units to U.S. customary units

\begin{tabular}{lccc}
\hline & Multiply & By & To obtain \\
\hline & Length & & \\
\hline kilometer $(\mathrm{km})$ & 0.6214 & mile (mi) & \\
\hline
\end{tabular}

Temperature in degrees Fahrenheit $\left({ }^{\circ} \mathrm{F}\right)$ may be converted to degrees Celsius $\left({ }^{\circ} \mathrm{C}\right)$ as follows:

$$
{ }^{\circ} \mathrm{C}=\left({ }^{\circ} \mathrm{F}-32\right) / 1.8 \text {. }
$$

\section{Datum}

Vertical coordinate information is referenced to either the North American Vertical Datum of 1988 (NAVD 88) or the National Geodetic Vertical Datum of 1929 (NGVD 29) and is specified in tables where vertical datum is reported. 


\section{Supplemental Information}

Specific conductance is given in microsiemens per centimeter at 25 degrees Celsius $\left(\mu \mathrm{S} / \mathrm{cm}\right.$ at $\left.25^{\circ} \mathrm{C}\right)$.

Concentrations of chemical constituents in water are given in either milligrams per liter $(\mathrm{mg} / \mathrm{L})$ or micrograms per liter $(\mu \mathrm{g} / \mathrm{L})$.

Activities for radioactive constituents in water are given in picocuries per liter (pCi/L).

This report contains Chemical Abstracts Service (CAS) Registry Numbers ${ }^{\circledR}$, which are a Registered Trademark of the American Chemical Society. The CAS recommends the verification of the CAS Registry Numbers through CAS Client Services ${ }^{M}$.

\section{Abbreviations}

\begin{tabular}{ll} 
DL & detection limit \\
DOC & dissolved organic carbon \\
EPA & U.S. Environmental Protection Agency \\
ETN & enhanced trends network \\
GAMA-PBP & Groundwater Ambient Monitoring and Assessment Program Priority \\
HBSL & Basin Project \\
HHB & health-based screening level \\
HHBP & human-health benchmark \\
LUS & human-health benchmark for pesticides \\
MAS & land-use study \\
MSS & major aquifer study \\
NAWQA & modeling support study \\
NWOL & National Water-Quality Assessment \\
PAS & National Water Quality Laboratory \\
OC & principal aquifer study \\
RSD & quality control \\
SD & relative standard deviation \\
SMCL & standard deviation \\
SSL & secondary maximum contaminant level \\
SSMDC & sample-specific critical level \\
USGS & sample-specific minimum detectable concentration \\
VFPS & U.S. Geological Survey \\
VOC & vertical flow-path study \\
& volatile organic compound \\
\hline
\end{tabular}




\title{
Groundwater-Quality and Select Quality-Control Data from the National Water-Quality Assessment Project, January 2017 through December 2019
}

\author{
By James A. Kingsbury, Laura M. Bexfield, Terri Arnold, MaryLynn Musgrove, Melinda L. Erickson, \\ James R. Degnan, Anthony J. Tesoriero, Bruce D. Lindsey, and Kenneth Belitz
}

\begin{abstract}
Groundwater-quality environmental data were collected from 983 wells as part of the National Water-Quality Assessment Project of the U.S. Geological Survey National Water Quality Program and are included in this report. The data were collected from six types of well networks: principal aquifer study networks, which are used to assess the quality of groundwater used for public water supply; land-use study networks, which are used to assess land-use effects on shallow groundwater quality; major aquifer study networks, which are used to assess the quality of groundwater used for domestic supply; enhanced trends networks, which are used to evaluate the time scales during which groundwater quality changes; vertical flow-path study networks, which are used to evaluate changes in groundwater quality from shallow to deeper depths; and modeling support studies, which are used to provide data to support groundwater modeling. Groundwater samples were analyzed for many water-quality indicators and constituents, including major ions, nutrients, trace elements, volatile organic compounds, pesticides, radionuclides, microbiological indicators, and some constituents of special interest (arsenic speciation, hexavalent chromium [chromium (VI)], and perchlorate). These groundwater-quality data, along with data from quality-control samples, are tabulated in this report and in an associated data release. Data for microbiological indicators for samples collected in 2016 are included in the companion data release.
\end{abstract}

\section{Introduction}

The National Water-Quality Assessment (NAWQA) Project of the U.S. Geological Survey (USGS) National Water Quality Program was fully implemented in 1991 and operates in about 10-year-long cycles. The NAWQA Project began its third cycle of studies in 2013. The NAWQA Project was designed to describe current water-quality conditions of the Nation's freshwater streams, rivers, and aquifers; to describe how water quality is changing with time; to improve understanding of the natural and human factors that affect water quality; to forecast future water-quality conditions; and to assess effects of water-quality stressors on aquatic ecosystems (Rowe and others, 2010, 2013).

The NAWQA Project groundwater assessments focus on the quality of groundwater used for public and domestic drinking-water supply; groundwater susceptibility to degradation; effects of natural and human factors on source, transport, and flux of contaminants to and within aquifers; groundwaterquality contributions to surface-water quality; and current and historical management practices relative to groundwater quality. Groundwater quality is studied at multiple scales: locally, regionally, and nationally. The primary regional scale at which groundwater data are collected during the third cycle of the NAWQA Project is the scale of the principal aquifers (Burow and Belitz, 2014). A principal aquifer is defined as a regionally extensive aquifer or aquifer system that has the potential to be used as a source of potable water. Principal aquifers were selected for assessment based on their national ranking as sources of water used for public supply (Arnold and others, 2016a).

Groundwater-quality data collected by the NAWQA Project each year are published in data series reports. The first four reports and associated data releases in this series published available data from samples collected May 2012 through December 2013 (Arnold and others, 2016a, b), January through December 2014 (Arnold and others, 2017a, b), January through December 2015 (Arnold and others, 2018a, b), and January through December 2016 (Arnold and others, 2020a, b). In appendix 1, table 1.1 lists the networks that are described in this report and are described in previous reports in this series.

\section{Purpose and Scope}

The purpose of this report is to describe the networks for which groundwater-quality samples were collected from 2017 to 2019 as part of the third cycle of NAWQA Project 
studies. Types of constituents analyzed include the following: water-quality indicators, major and minor ions, nutrients, volatile organic compounds (VOCs), pesticides, radionuclides, microbiological indicators, and select constituents of special interest (arsenic speciation, hexavalent chromium [chromium (VI)], and perchlorate). The water-quality data are presented in tables formatted as tab-delimited American Standard Code for Information Interchange text files, which may be imported into spreadsheet, database, or statistical software for manipulation and analysis. These water-quality data tables are publicly available from a data release (Kingsbury and others, 2020). The data release includes data collected primarily during 2017 and 2018. It also includes data for 10 networks sampled in 2019 and microbiological indicator results for one network with wells sampled in 2016 and 2017.

\section{Groundwater Study Design}

Groundwater-quality samples were collected from wells that were organized into networks (fig. 1) for study purposes. A network is a group of wells that have been selected for sampling based on specific hydrogeologic conditions, land use, or other design criteria. Many networks have wells that were sampled in multiple decadal sampling periods; however, if a network well was damaged or destroyed or had too little water, or the current owner would not permit sampling, then that well was not resampled during this sampling period. Maps and tables in this report and in Kingsbury and others (2020) have well identification numbers assigned by the NAWQA Project to identify the wells; because some wells could not be resampled, some networks do not have consecutively numbered NAWQA Project identification numbers. As used on maps showing network-specific information (figs. 2-37), the identification numbers are shown either as numbers only (the numeric part of the NAWQA well identification number; table 1 in Kingsbury and others, 2020) or a combination of numbers and letters that indicate a particular well within the network. For a few networks, some wells fall outside of areas delineated for the network. In some cases, they are outside the study area because the boundaries are based on national-scale spatial data and local aquifer or land-use boundaries may differ. In some cases, the local land use may not be accurately classified at the national scale. Although a well may be outside the published study area boundary, it will still be in the aquifer and the designated land use for the network. The NAWQA well identification numbers listed in table 1 of Kingsbury and others (2020) are a combination of the network name and the NAWQA Project identification number. Data from six primary types of groundwater study networks are presented in this report (fig. 1): principal aquifer study (PAS), land-use study (LUS), major aquifer study (MAS), enhanced trends networks (ETNs), vertical flow-path study (VFPS), and modeling support study (MSS).
Wells in PAS, LUS, and MAS networks were selected randomly using an equal-area grid to divide the study area of each network (Scott, 1990). The equal-area grid method allows for evaluation of constituent concentrations at a regional scale (Belitz and others, 2010). For LUS networks, random potential sampling locations in each grid cell were generated by a software program (Scott, 1990), and monitoring wells were subsequently installed as near to the randomly selected locations as possible. Study areas for LUS networks included the areal extents of the primary aquifer that underlie a specific land use (for example, orchard) of interest. For MAS and PAS networks, one well per grid cell was randomly selected from a population of existing domestic or publicsupply wells (Scott, 1990; Gilliom and others, 1995). For PAS networks, if no public-supply well was available within a grid cell (for example, because permission to sample could not be obtained), an additional well was selected within an adjacent grid cell, not to exceed four wells in two adjacent grid cells. Equal-area grids used for network design are shown only on figures relating to PAS networks because the grids are not available for LUS or MAS networks designed during the first two decades of sampling.

The ETN, VFPS, and MSS wells were selected from existing networks where possible. The ETN wells are in hydrogeologic settings where changes in hydrologic conditions, land use, or contaminant inputs are expected to be reflected quickly in groundwater (less than 10 years). The VFPS wells were "nested" wells with various depths collocated in a selected area to represent vertical gradients of groundwater flow to enhance the understanding of how contaminants move through aquifers over timespans of more than a decade. The MSS wells were selected to provide key data to support specific modeling goals.

\section{Principal Aquifer Study Networks}

The PAS networks consist of public-supply wells, and water is sampled from the part of the aquifer used for the public drinking-water supply (Burow and Belitz, 2014). The PAS networks were designed to focus on public-supply wells that tap deeper groundwater than typical domestic-supply wells. Data are collected over principal aquifers rather than targeting smaller areas, which was done for the MAS networks. The data collected from these networks can be used to characterize the deep groundwater, thus completing a three-dimensional picture of groundwater quality and complementing previous NAWQA studies (Burow and Belitz, 2014). Public-supply wells are generally the deepest wells sampled. Wells in PAS networks are sampled once to assess groundwater-quality conditions in the study areas. The extents of PAS network areas are based on the USGS (2003) map of principal aquifers and may be modified in some areas, as described in this report. Data from the following PAS networks are included in this report: Colorado Plateaus PAS network (coplpas1; fig. 2), Edwards-Trinity aquifer system PAS network 


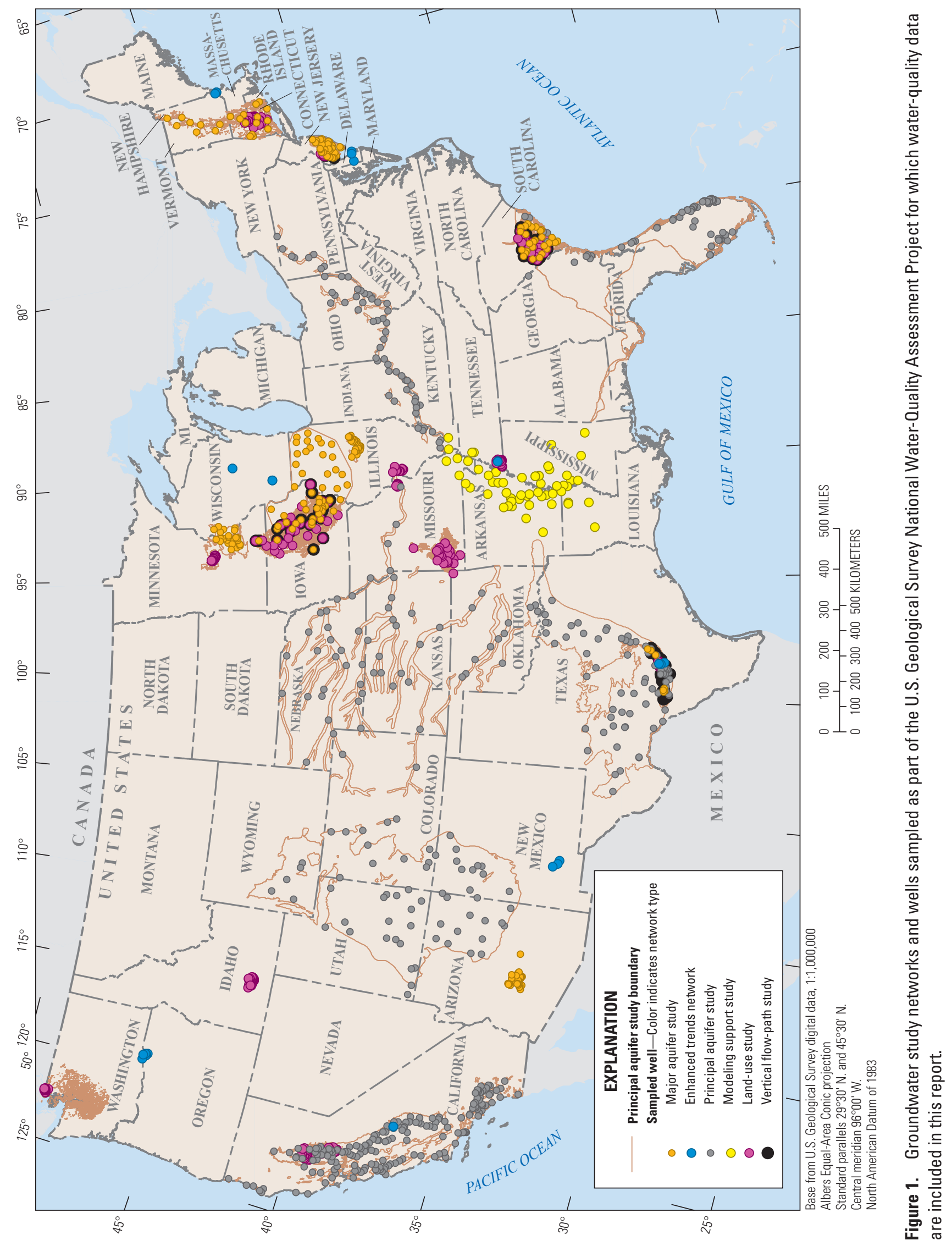


(edtrpas1; fig. 3), stream-valley aquifers PAS network 1 (strvpas1; fig. 4), stream-valley aquifers PAS network 2 (strvpas2; fig. 5), and surficial aquifer PAS network (surfpas1; fig. 6). Two additional PAS networks have been constructed from wells that are part of an ambient groundwater monitoring project in California (USGS, 2020b): the California Coastal Basin aquifers PAS network (cacbpas1; fig. 7) and the Central Valley aquifer system PAS (cvalpas1; fig. 8).

\section{Colorado Plateaus Principal Aquifer Study Network (coplpas1)}

The Colorado Plateaus aquifers underlie an area of about 141,000 square miles $\left(\mathrm{mi}^{2}\right)$, which has a population of about 1.2 million people (U.S. Census Bureau, 2010). The aquifer ranks 28th in the Nation as a source of groundwater for public supply, with about 102 million gallons per day (Mgal/d) withdrawn for public supply in 2000 (Maupin and Barber, 2005). The aquifers underlie parts of southwestern Wyoming, eastern Utah, western Colorado, northwestern New Mexico, and northeastern Arizona. Most of the land overlying these aquifers has natural cover (97 percent) with relatively small areas of pasture and agricultural land (1.9 percent) and urban and other developed land (1 percent) (Homer and others, 2015).

The coplpas1 consists of several regional aquifers: Uinta-Animas, Mesaverde, Dakota-Glen Canyon, and the Coconino-De Chelly aquifers consisting of Tertiary- to Permian-age rocks (Davidson, 1979; Robson and Banta, 1995; Glover and others, 1998). The aquifers are each within several formations, primarily sandstones within conglomerate, siltstone, and shale layers with varying degrees of lithification. The sedimentary rocks making up these aquifers are thousands of feet thick, offset by faults, variably uplifted, or subsided.

The coplpas 1 consists of 60 public-supply wells (fig. 2). Because parts of the region are sparsely populated, and public-supply wells are not evenly distributed, the study area was delineated by creating 12.4-mile buffers around existing public-supply wells. An equal-area grid was then created within the area defined by all the buffer areas (fig. 2). Each well was selected from a 60-cell equal-area grid that extended across the aquifer system. The wells ranged from 100 to 3,636 feet (ft) in depth, with a median of $565 \mathrm{ft}$ (appendix 2, table 2.1). Open intervals were generally about $10-1,790 \mathrm{ft}$ (appendix 2, table 2.2). Samples were collected during June and December 2017.

\section{Edwards-Trinity Aquifer System Principal Aquifer Study Network (edtrpas1)}

The Edwards-Trinity aquifer system underlies an area of about $78,000 \mathrm{mi}^{2}$, from west Texas to southeastern Oklahoma. The aquifer system is an important water source with primary water use for public supply and irrigation. About $411 \mathrm{Mgal} / \mathrm{d}$ were withdrawn for public supply in 2000, which ranks the aquifer 11th in the Nation as a source of groundwater for public supply (Maupin and Barber, 2005). About 11 million people live in the area overlying the aquifer system, including the urban areas of Dallas-Fort Worth, Austin, and San Antonio, Texas. Land use overlying the aquifer system is composed primarily of natural land cover (including rangeland; 81 percent) and agricultural land (12 percent) with relatively small areas of urban and other developed land (7 percent) (Homer and others, 2015).

The Edwards-Trinity aquifer system is composed of three aquifers of Cretaceous-age carbonate and clastic rocks, which are described in detail by Ryder (1996) and George and others (2011) and summarized here: from west to east, the aquifers are the Edwards-Trinity aquifer, the Edwards aquifer, and the Trinity aquifer. The Edwards aquifer overlies and is in part hydraulically connected to the Trinity aquifer, whereas the Trinity and Edwards-Trinity aquifers are stratigraphically equivalent in part and are hydraulically connected in places (Ryder, 1996). The climate of the region is highly variable with mean annual precipitation decreasing from east to west by an order of magnitude.

The Edwards-Trinity aquifer-locally referred to as the Edwards-Trinity (Plateau) aquifer - extends across much of the southwestern part of Texas and is composed of Edwards Group limestone and dolomite in the upper part and Trinity Group sands in the lower part. Irrigation is the primary water use for the Edwards-Trinity aquifer. The Edwards-Trinity aquifer area consists of flat to rolling plains that are dissected in places, forming steep-walled canyons. The aquifer area is bounded on the west by mountain ranges. The aquifer slopes generally to the south and southeast, and regional groundwater flow is to the southeast. Recharge occurs by direct precipitation on the land surface where the aquifer is unconfined; in the deeper zones, the aquifer is confined.

The Edwards aquifer-locally referred to as the Edwards (Balcones Fault Zone) aquifer-consists of partially dissolved and highly permeable limestone of the Georgetown Formation and the Edwards Group. The aquifer is present in a narrow band ranging from about 4 to 30 miles wide and 240 miles long and is coincident with the Balcones Fault Zone, along which the aquifer dips steeply to the south and southeast. Faulting resulted in a series of blocks of Edwards aquifer rocks that are partially to completely offset and divide the unconfined and confined parts of the aquifer (Maclay and Small, 1983). Geographically, the Edwards aquifer covers the smallest area of the three aquifers of the Edwards-Trinity aquifer system (fig. 3) but is the most productive, and public supply is its primary water use. The Edwards aquifer is one of the most productive aquifers in the Nation (Sharp and Banner, 1997) and is the primary water supply for the city of San Antonio; it is a designated sole-source aquifer (U.S. Environmental Protection Agency [EPA], 2018). Recharge to the Edwards aquifer occurs primarily by streamflow losses across the fault zone and by direct infiltration on the recharge zone or by leakage from the underlying Trinity aquifer. Regional groundwater flow is to the east and 


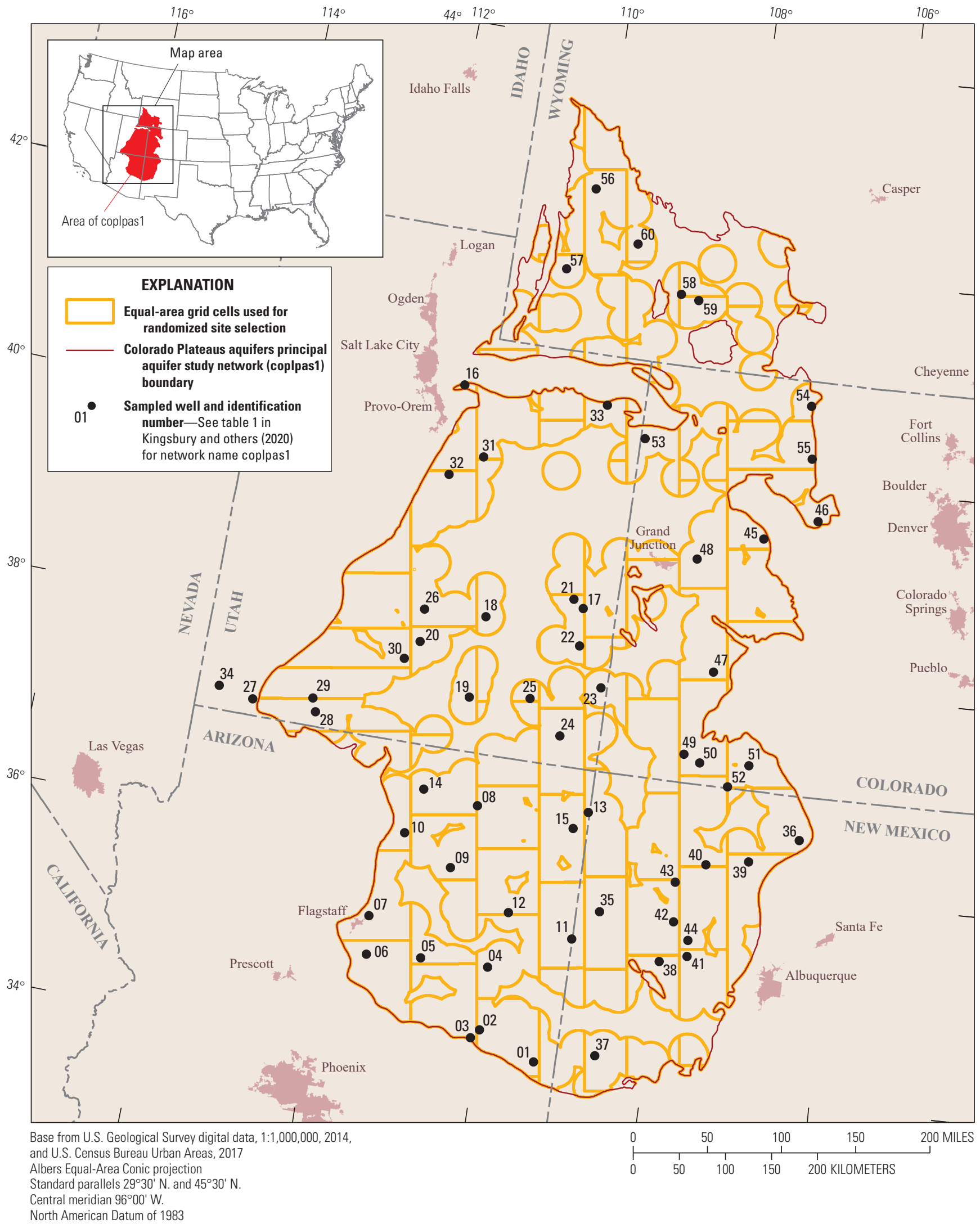

Figure 2. Study area and wells sampled as part of the Colorado Plateaus aquifers principal aquifer study network (coplpas1) for the U.S. Geological Survey National Water-Quality Assessment Project. 


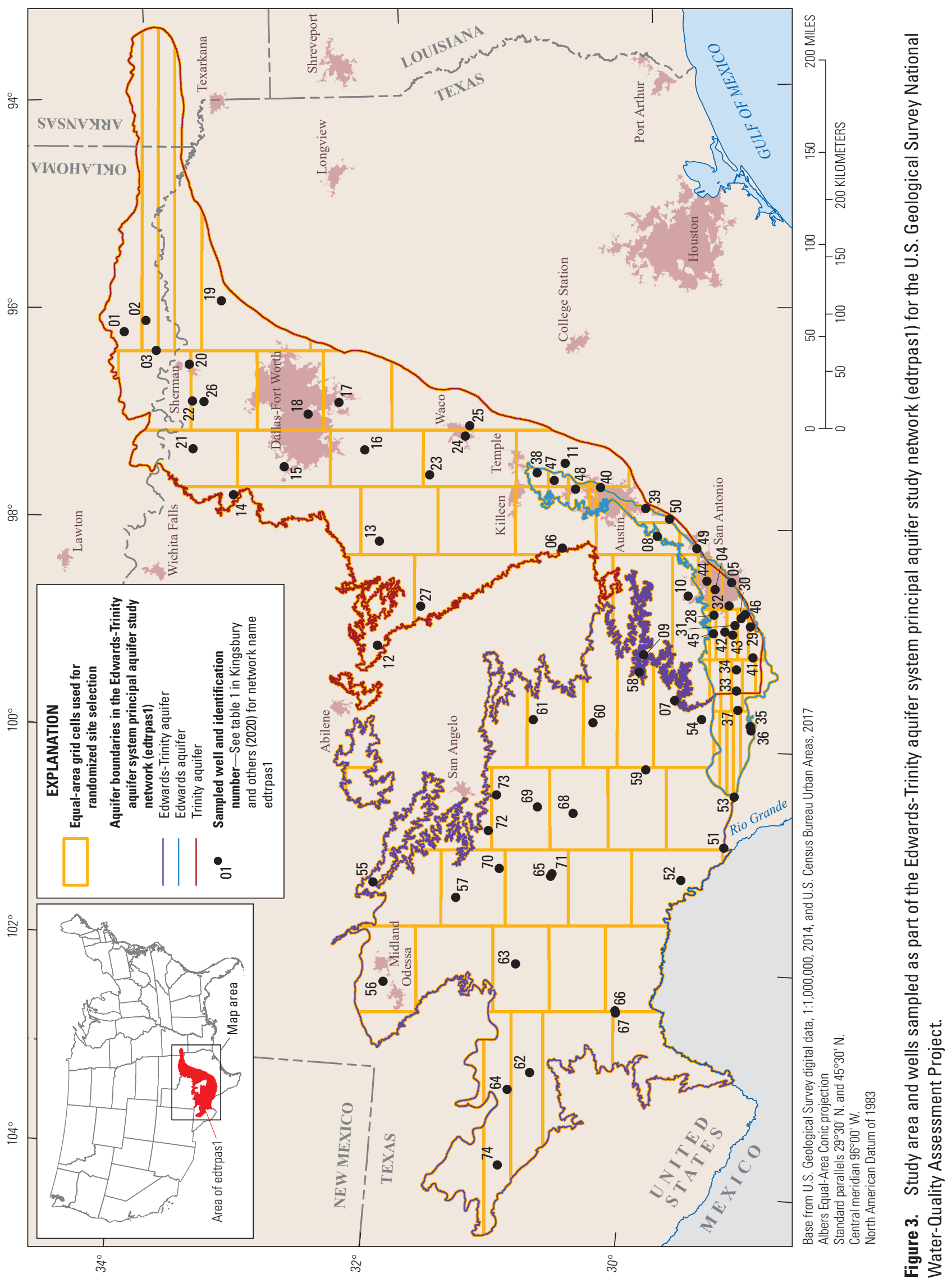




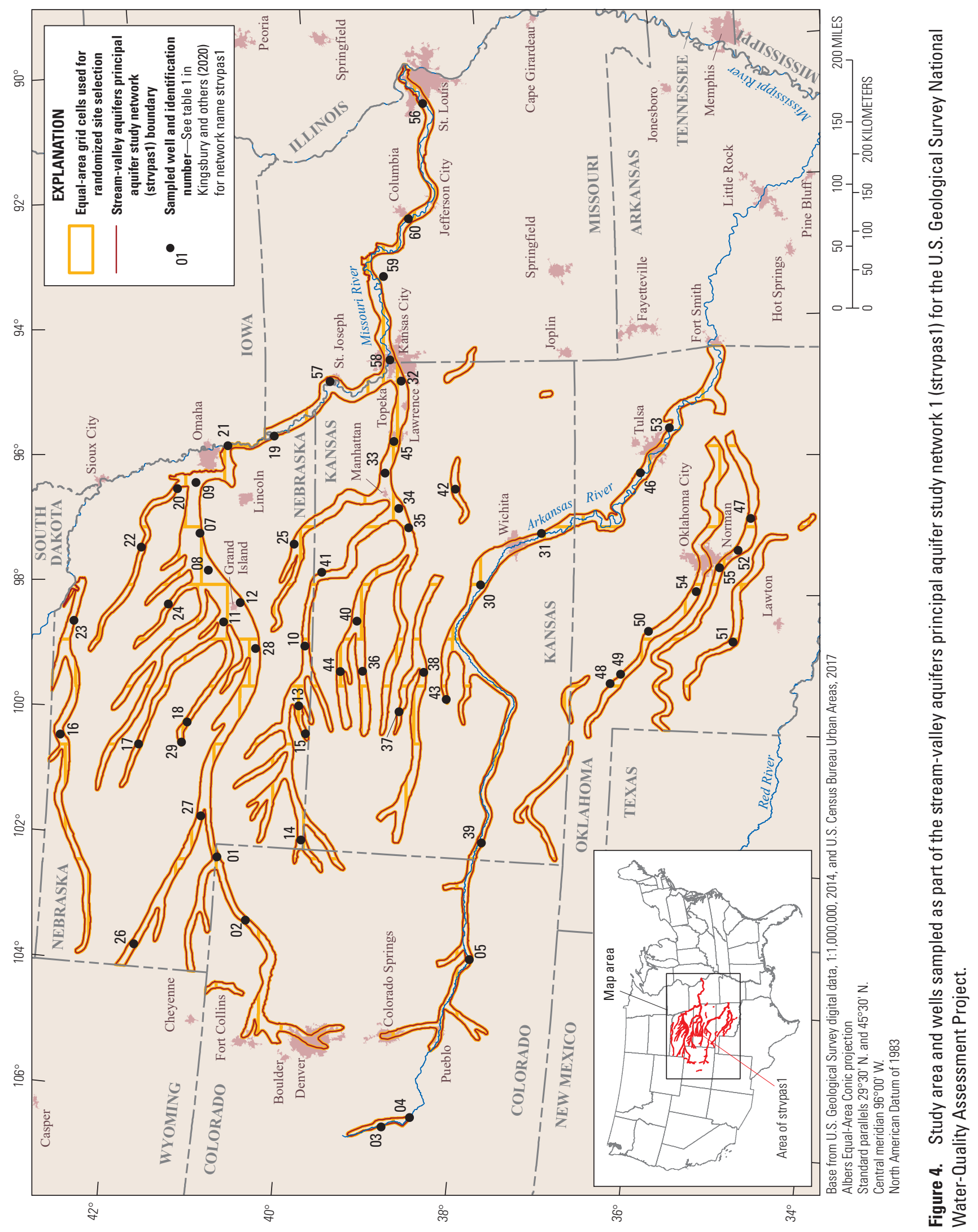




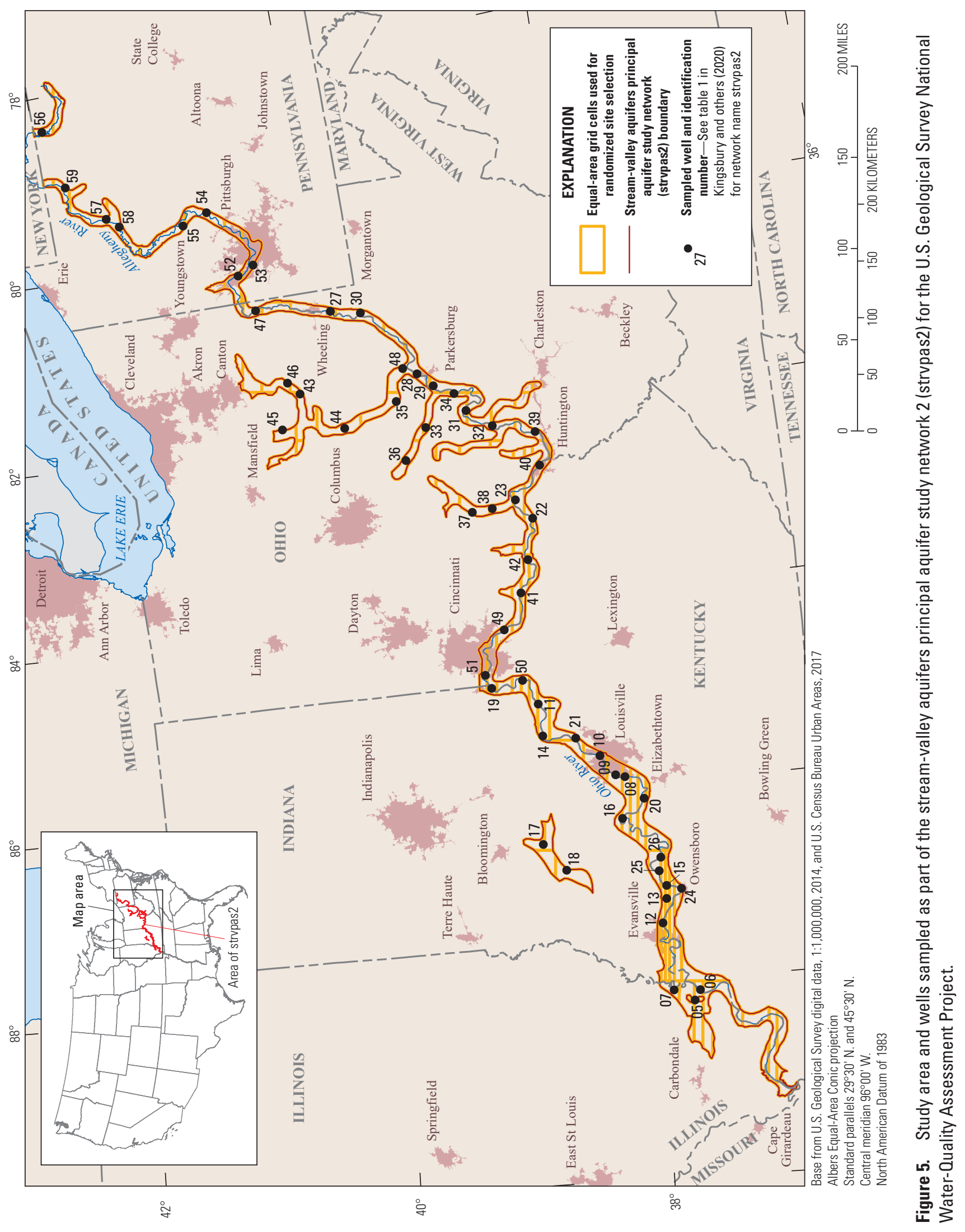




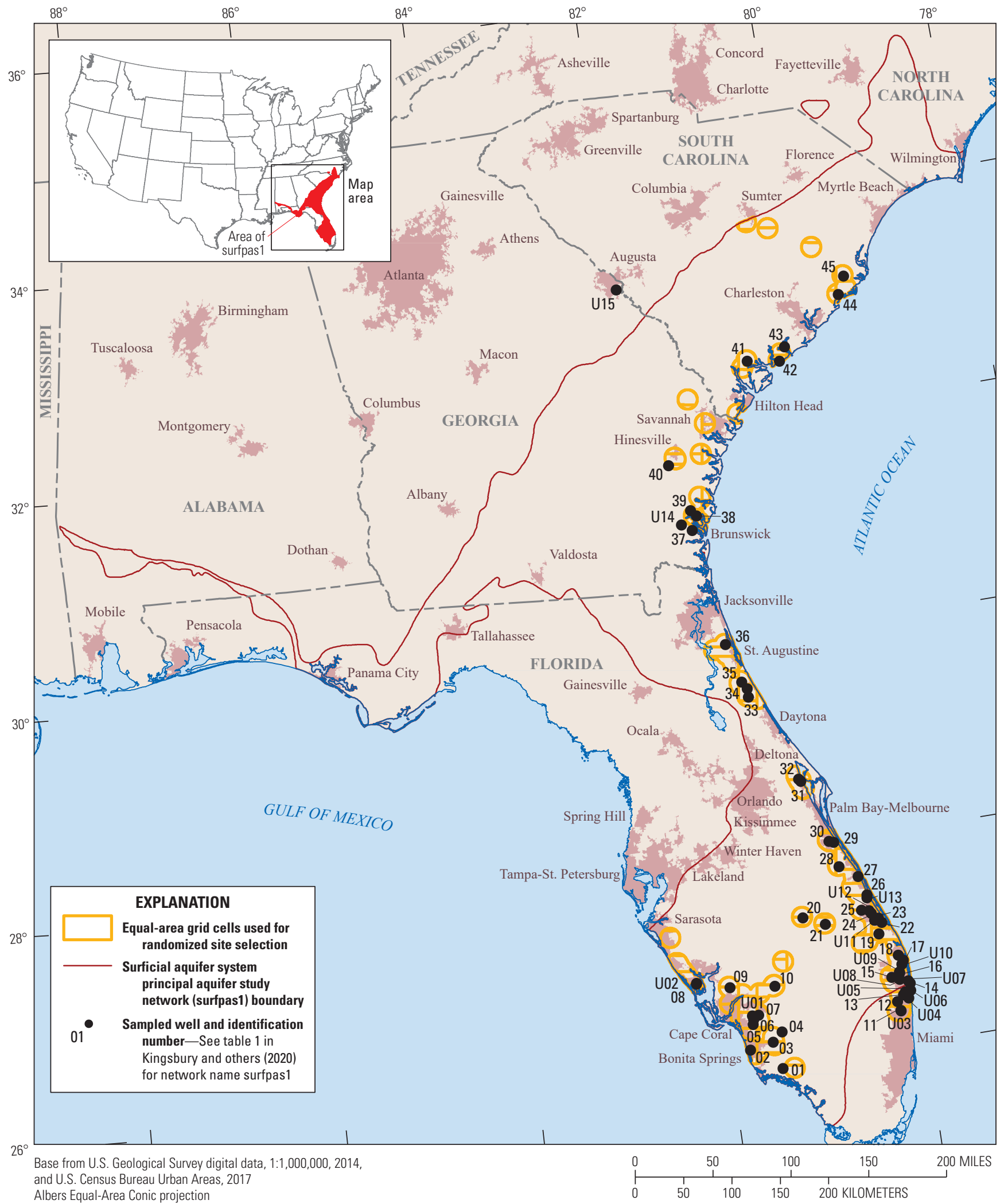

Albers Equal-Area Conic projection

Standard parallels $29^{\circ} 30^{\prime} \mathrm{N}$. and $45^{\circ} 30^{\prime} \mathrm{N}$.

Central meridian $96^{\circ} 00^{\prime} \mathrm{W}$.

North American Datum of 1983

Figure 6. Study area and wells sampled as part of the surficial aquifer system principal aquifer study network (surfpas1) for the U.S. Geological Survey National Water-Quality Assessment Project. 


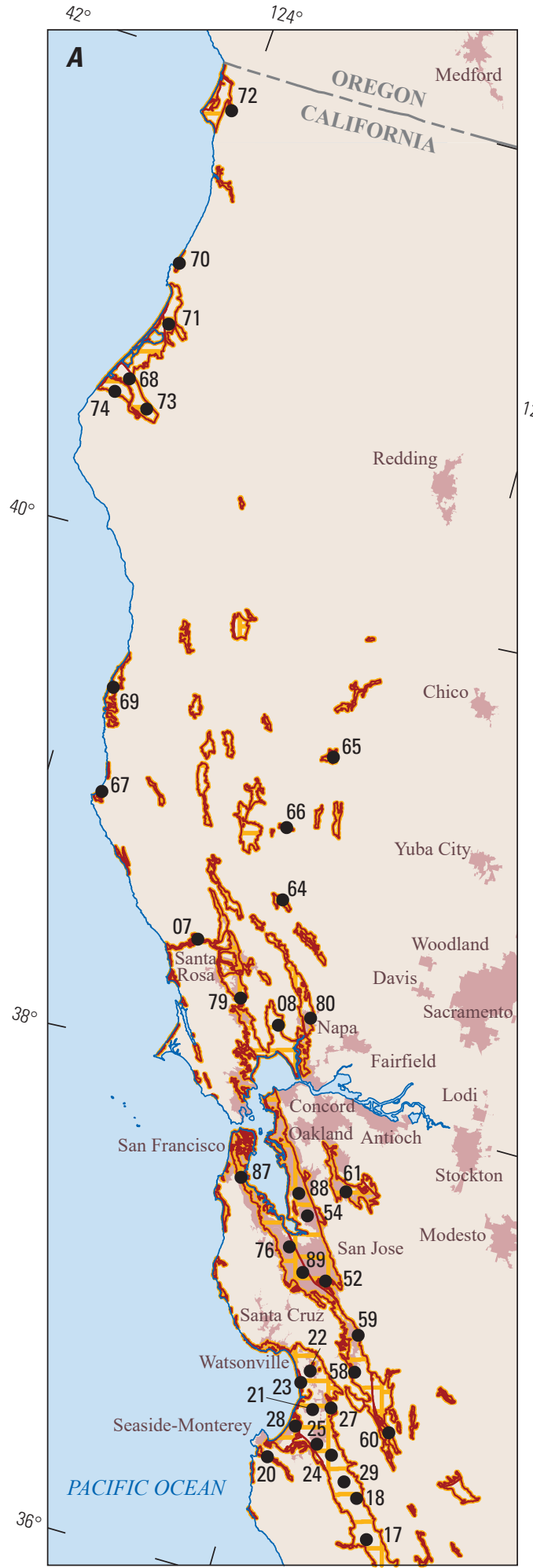

Base from U.S. Geological Survey digital data, 1:1,000,000, 2014, and U.S. Census Bureau Urban Areas, 2017

Albers Equal-Area Conic projection

Standard parallels $29^{\circ} 30^{\prime} \mathrm{N}$. and $45^{\circ} 30^{\prime} \mathrm{N}$.

Central meridian $96^{\circ} 00^{\prime} \mathrm{W}$.

North American Datum of 1983

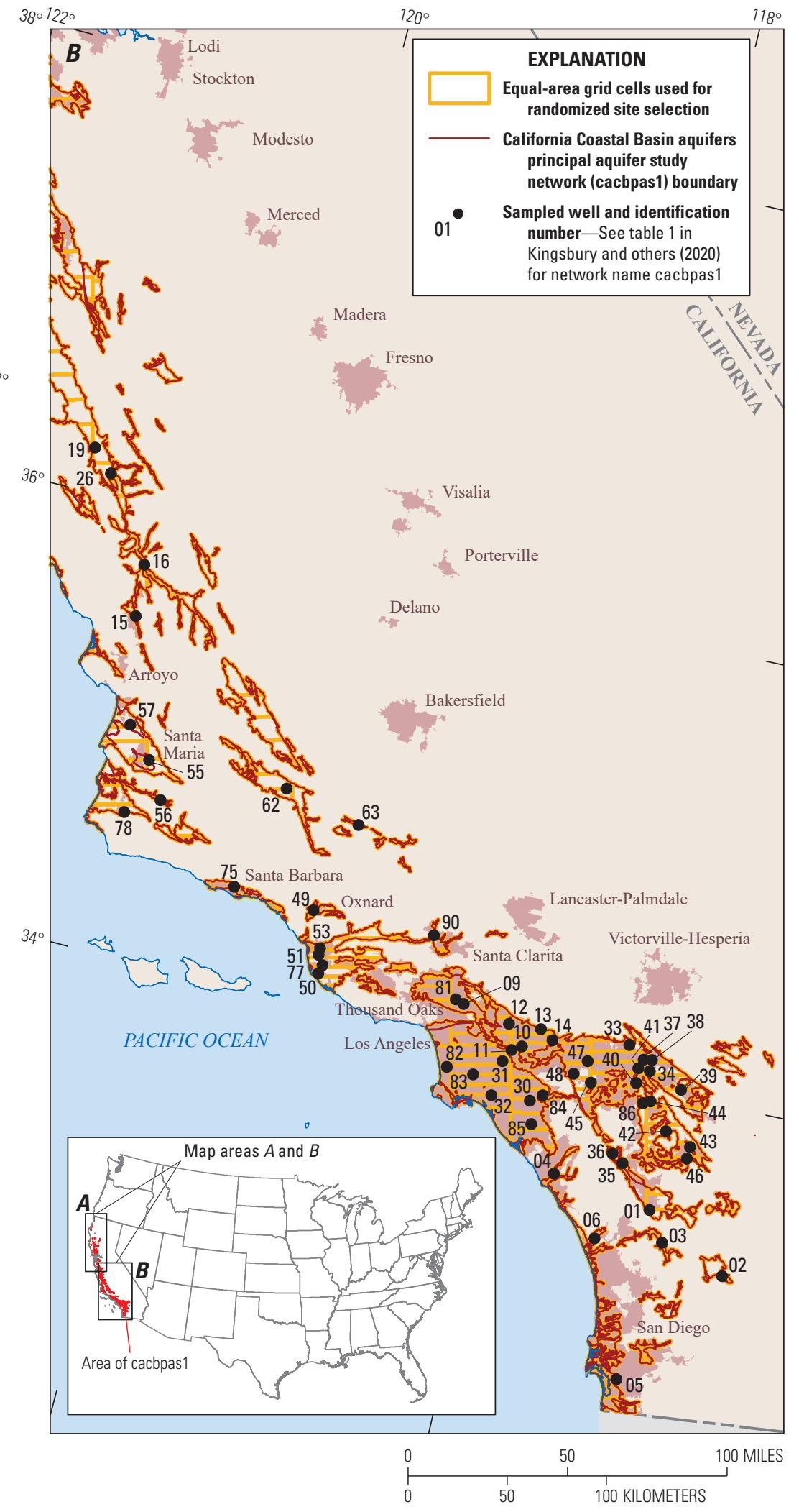

Figure 7. Study area and wells sampled as part of the California Coastal Basin aquifers principal aquifer study network (cacbpas1) for the U.S. Geological Survey National Water-Quality Assessment Project. 


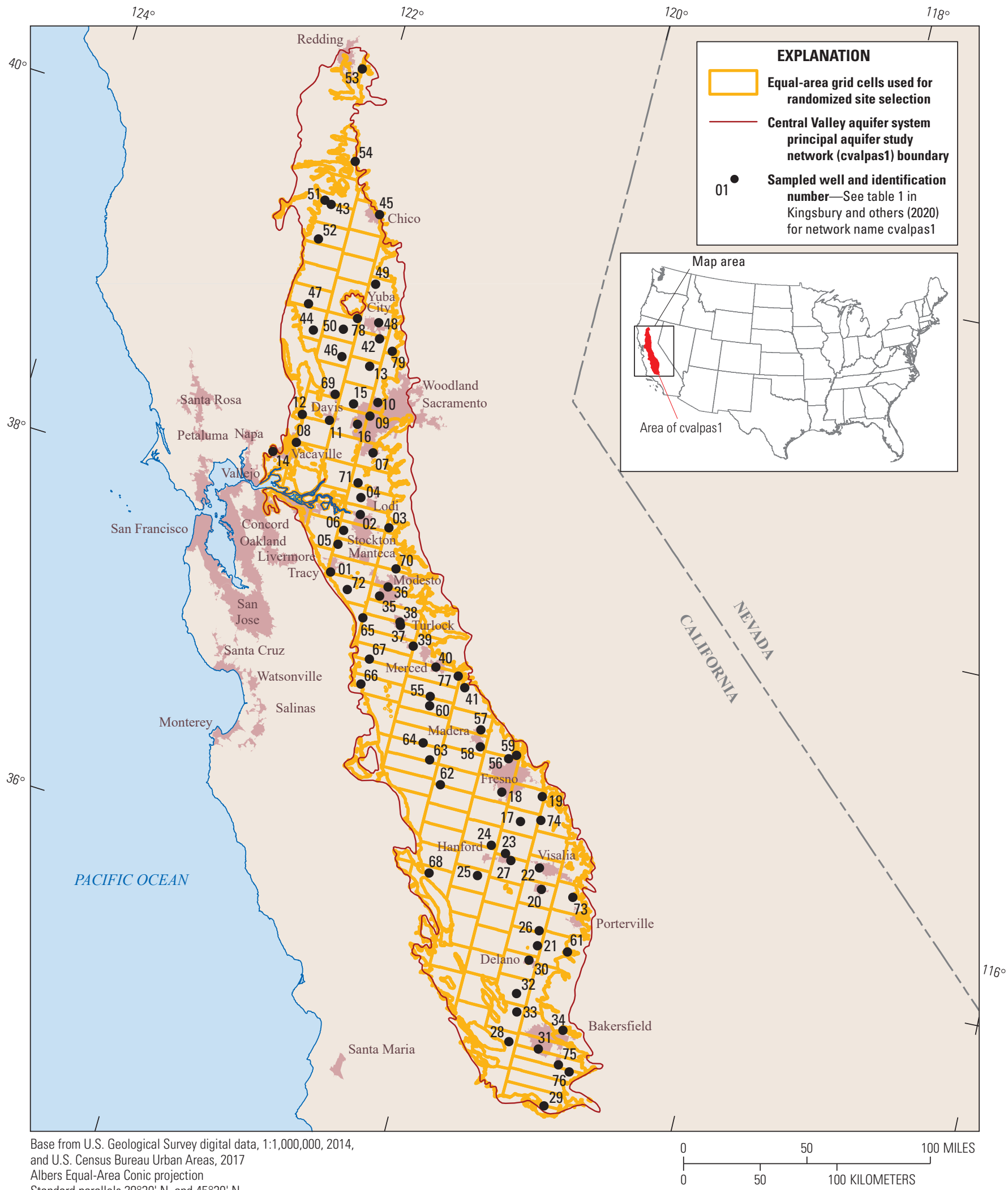

Standard parallels $29^{\circ} 30^{\prime} \mathrm{N}$. and $45^{\circ} 30^{\prime} \mathrm{N}$.

Central meridian $96^{\circ} 00^{\prime} \mathrm{W}$.

North American Datum of 1983

Figure 8. Study area and wells sampled as part of the Central Valley aquifer system principal aquifer study network (cvalpas1) for the U.S. Geological Survey National Water-Quality Assessment Project. 
northeast. Natural discharge occurs through large springs, which provide habitat for several threatened and endangered species (Texas State University, 2020).

The Trinity aquifer extends across much of central and northeastern Texas into southeastern Oklahoma in an arcuate band about 550 miles long. The Trinity aquifer consists of interbedded sandstone, sand, limestone, and shale. The Trinity aquifer is composed of several smaller aquifers that are locally referred to differently in different parts of its extent; it is commonly called the Antlers aquifer in Oklahoma. The Trinity aquifer's primary use is public supply, and its importance increases north of Austin; it is one of the most extensive and highly used groundwater resources in Texas, and large water level declines have occurred in some parts of the aquifer. The aquifer dips to the south and southeast and is unconfined where the formations outcrop, becoming confined downdip. The aquifer is characterized by large vertical variability and is often described by division into an upper, middle, and lower Trinity aquifer. Recharge is primarily from infiltration of rainfall; some recharge also occurs where streams lose water to the aquifer. Natural discharge occurs to many small (less than 10 cubic feet per second) springs.

The Edwards-Trinity aquifer system PAS network (edtrpas1; fig. 3) includes 74 public-supply wells distributed across the extent of the three individual aquifers; wells were selected using three 25-cell equal-area grids, one for each of the three aquifers (only 24 wells were sampled in the Edwards-Trinity aquifer) (fig. 3). Samples were collected between November 2016 and August 2017. Wells ranged in depth from about 25 to $3,200 \mathrm{ft}$ deep, with a median well depth of about $400 \mathrm{ft}$ (appendix 2, table 2.1). Open intervals ranged from about 15 to $490 \mathrm{ft}$ (appendix 2, table 2.2).

\section{Stream-Valley Aquifers Principal Aquifer Study Network 1 (strvpas1)}

Stream-valley aquifers are not represented on the USGS principal aquifer map (USGS, 2003); however, Sargent and others (2008) compiled water use from these aquifers and delineated alluvial deposits in the valleys along major rivers and streams that compose these aquifers. Stream-valley aquifers rank as the 12th largest provider of groundwater for public supply in the Nation, so the NAWQA Project sampled selected parts of these aquifers based on withdrawals for public supply.

The stream-valley aquifers sampled for this study underlie an area of about $41,200 \mathrm{mi}^{2}$ in the sedimentary deposits of the Arkansas, Missouri, and Red River drainages. About 4.5 million people live in the area overlying these aquifers, and about $167 \mathrm{Mgal} / \mathrm{d}$ were withdrawn for public supply in 2000 (Sargent and others, 2008). The study area includes parts of five States (Oklahoma, Nebraska, Kansas, Missouri, and Colorado). Most of the area overlying the aquifer is undeveloped (54 percent). Agricultural land use makes up about 39 percent and urban land use makes up about
7 percent of the study area. Major cities in the study area include Omaha, Nebraska; Kansas City, Missouri; and Tulsa, Oklahoma.

The stream-valley aquifers are associated with the sand and gravel deposits in the valleys of the stream or river that typically is hydraulically connected to the aquifers (Miller and Appel, 1997); consequently, these aquifers usually are only as much as a few miles wide but can extend over long distances (Ryder, 1996). These aquifers typically are no more than $100 \mathrm{ft}$ thick, but along some of the large rivers may be as much as $160 \mathrm{ft}$ thick (Miller and Appel, 1997). The groundwater in these aquifers usually is unconfined or under water-table conditions; however, locally, where coarse-grained sediments are overlain by low permeable silt or clay, confined conditions may exist (Miller and Appel, 1997). Recharge to the aquifer is from infiltration of precipitation and drainage of surface water from the streams and rivers adjacent to these aquifers (Ryder, 1996; Miller and Appel, 1997).

Groundwater quality in these stream-valley aquifers was evaluated by sampling 59 public-supply wells randomly distributed in an equal-area grid (strvpas1; fig. 4). The wells ranged from about 30 to $200 \mathrm{ft}$ deep, with a median depth of $82 \mathrm{ft}$ (appendix 2, table 2.1). Samples were collected between June and September 2018.

\section{Stream-Valley Aquifers Principal Aquifer Study Network 2 (strvpas2)}

The stream-valley aquifers sampled for this study underlie an area of about 9,600 $\mathrm{mi}^{2}$ in the sedimentary deposits of the Ohio and Allegheny River drainages and parts of a few large tributaries (fig. 5). About 2.8 million people live in the area overlying these aquifers, and about $200 \mathrm{Mgal} / \mathrm{d}$ were withdrawn for public supply in 2000 (Sargent and others, 2008). The study area includes parts of six States (Illinois, Kentucky, Indiana, Ohio, West Virginia, and Pennsylvania). Most of the area overlying the aquifer is undeveloped (60 percent). Agricultural land use makes up about 27 percent and urban land use makes up about 13 percent of the study area. Major cities in the study area include Pittsburg, Pennsylvania; Charleston, West Virginia; Cincinnati, Ohio; and Louisville, Kentucky.

The stream-valley aquifers are within the Holocene-age sand and gravel deposited as alluvium along the valleys of major streams. Some of these sediments are reworked glacial deposits that were eroded and transported downstream, and they are associated with rivers such as the Allegheny and Ohio Rivers that have their headwaters in glaciated areas (Trapp and Horn, 1997). The stream-valley aquifers are associated with the sand and gravel deposits in the valleys of the stream or river that typically is hydraulically connected to the aquifers (Trapp and Horn, 1997). Groundwater in the stream-valley aquifers commonly is under water-table, or unconfined, conditions but confined conditions occur in places where clay or silt make up local confining units (Lloyd and Lyke, 1995). 
Recharge to the aquifer is from infiltration of precipitation and drainage of surface water from the streams and rivers adjacent to these aquifers (Lloyd and Lyke, 1995; Trapp and Horn, 1997).

Groundwater quality in these stream-valley aquifers was evaluated by sampling 55 public-supply wells randomly distributed in an equal-area grid (strvpas2; fig. 5). The wells ranged from about 45 to $135 \mathrm{ft}$ deep, with a median depth of $80 \mathrm{ft}$ (appendix 2, table 2.1). Samples were collected between June and September 2019.

\section{Surficial Aquifer System Principal Aquifer Study Network (surfpas1)}

The surficial aquifer system underlies an area of about 63,600 $\mathrm{mi}^{2}$ in parts of Alabama, South Carolina, Georgia, and Florida. About 14 million people live in the area overlying this aquifer (U.S. Census Bureau, 2010), and about $270 \mathrm{Mgal} / \mathrm{d}$ were withdrawn for public supply in 2015 (Lovelace and others, 2020). The aquifer was ranked 16th in withdrawals for public supply (Maupin and Barber, 2005). Much of the area overlying the aquifer is wetlands, forest, and open water (71 percent). Agricultural land use makes up about 18 percent and urban land use makes up about 11 percent of the study area. The part of the surficial aquifer system sampled for this study was defined by creating 10-kilometer buffer areas around water supply wells and equal-area grids for the aggregated buffers in parts of Florida, Georgia, and South Carolina (fig. 6). Major cities in or near the study area include Savannah, Georgia; Hilton Head, South Carolina; and Palm Beach and Fort Meyers, Florida, among many additional communities.

The sediments that make up the surficial aquifer system include unconsolidated Miocene- to Holocene-age sand and gravel as well as shelly sand and shell deposits (Miller, 1990). These sediments make up nine geologic formations in Florida but are complexly interbedded lenses such that all the formations are not present at a given location (Miller, 1990). In Georgia and South Carolina, the surficial aquifer system consists of undifferentiated Pleistoceneage terrace deposits and Holocene sand deposits (Miller, 1990). The surficial aquifer system typically is less than $100 \mathrm{ft}$ thick, but it thickens to the south in Florida where it is as much as $400 \mathrm{ft}$ thick (Miller, 1990). Groundwater in the surficial aquifer system is mostly unconfined, but locally, fine-grained deposits can result in semiconfined to confined conditions.

Groundwater quality in the surficial aquifer system was evaluated by sampling 45 spatially-distributed (randomized) public-supply wells (Scott, 1990) sampled for the purposes of assessing groundwater quality at a regional scale, and 15 additional wells sampled for the purposes of understanding the factors affecting groundwater quality (surfpas1; fig. 6).
The wells ranged from about 20 to $270 \mathrm{ft}$ deep, with a median depth of $108 \mathrm{ft}$ (appendix 2, table 2.1). Samples were collected between June and November 2019.

\section{California Coastal Basin Aquifers Principal Aquifer Study Network (cacbpas1)}

The California Coastal Basin aquifers extend along much of the length of California's coast and underlie about $10,200 \mathrm{mi}^{2}$ in groundwater basins within the coastal mountains. The study area includes coastal and inland basins (fig. 7) with a population of about 21 million people (U.S. Census Bureau, 2010). This aquifer is ranked fourth in the amount of groundwater used for public supply with about $960 \mathrm{Mgal} / \mathrm{d}$ withdrawn in 2015 (Lovelace and others, 2020). Land use in the study area is about 34-percent urban, 54-percent undeveloped land, and 12-percent agricultural (Homer and others, 2015). The cities of Los Angeles, San Diego, San Francisco, and Oakland and many other communities overlie this aquifer system.

The California Coastal Basin aquifers consist of more than 100 individual basin-fill aquifers in depressions between the mountains that are along California's western coast (Planert and Williams, 1995). The basins are filled with marine and alluvial sedimentary deposits, as much as tens of thousands of feet thick in some basins, but most of the freshwater resources are in the upper thousand feet or so of unconsolidated to semiconsolidated sand and gravels derived from the surrounding mountains. The hydrology and lithology of each basin differ (Planert and Williams, 1995), but two or more aquifers separated by confining units commonly are present (California Department of Water Resources, 2015).

The California Coastal Basin aquifers PAS network (cacbpas1; fig. 7) includes 90 public-supply wells distributed across the extent of the aquifer system. Wells were selected using an area grid that extended across the extent of the aquifer system. This network was designed by the NAWQA Project using the same approach as the other PAS networks; however, the network was constructed using a subset of wells that were sampled as part of the California Groundwater Ambient Monitoring and Assessment Program Priority Basin Project (GAMA-PBP), a cooperative project between the USGS and the California State Water Resources Control Board (Belitz and others, 2003, 2015). These data are comparable to NAWQA data because the GAMA-PBP was designed using a similar framework, and data were collected using the same field and analytical methods as used by the NAWQA Project. Data for samples collected by GAMA-PBP between 2004 and 2017 are available from USGS (2018), and the data also have been published in a series of data series reports (appendix 3, table 3.1). Wells in the cacbpas 1 ranged from 50 to $1,950 \mathrm{ft}$ deep, with a median well depth of $500 \mathrm{ft}$ (appendix 2, table 2.1). 


\section{Central Valley Aquifer System Principal Aquifer Study Network (cvalpas1)}

The Central Valley aquifer system underlies an area of about 20,000 $\mathrm{mi}^{2}$ in central California. It lies between the Cascade Range to the north, the Sierra Nevada mountains to the east, the Klamath Mountains and Coast Ranges to the west, and the Tehachapi Mountains to the south (fig. 8). About 6.8 million people reside in areas overlying this aquifer system (U.S. Census Bureau, 2010). Groundwater is an important source of drinking water in the Central Valley, and withdrawals for public supply were about $524 \mathrm{Mgal} / \mathrm{d}$ in 2015 (Lovelace and others, 2020). This aquifer system was ranked sixth in withdrawals for public supply (Maupin and Barber, 2005). Large amounts of groundwater also are used for irrigation with a total of about $11,100 \mathrm{Mgal} / \mathrm{d}$ for all uses withdrawn in 2015 (Lovelace and others, 2020) within this nationally important agricultural region. Land use in the area overlying the Central Valley aquifer system is primarily agricultural (60 percent) and natural land cover (29 percent) with a moderate amount (11 percent) of urban and other developed land (Homer and others, 2015). Sacramento, Fresno, and Bakersfield are among the largest urban areas overlying this aquifer system (fig. 8).

The lithologies that are included in the mountain ranges surrounding the Central Valley include igneous and metamorphic rock. The tens of thousands of feet of sediments that make up the Central Valley aquifer system include deposits from the weathering of the surrounding mountains and marine sediments that were deposited when the valley was covered by the Pacific Ocean (Planert and Williams, 1995). The upper sediments (about 1,000 ft) are the primary water-bearing units and are the result of stream deposition from erosion of the surrounding mountains when sea level declined. The sediments that make up the Central Valley aquifer system include sand and gravel, but substantial amounts of fine-grained material (silts and clays) result in hydrologic conditions that include unconfined, semiconfined, and confined flow (Planert and Williams, 1995).

The Central Valley aquifer system PAS network (cvalpas1; fig. 8) includes 79 public-supply wells distributed across the extent of the aquifer system. Wells were selected using a 120-cell equal-area grid (16,300 $\left.\mathrm{mi}^{2}\right)$ across most of the extent of the aquifer system. This network also is constructed from a subset of wells that are a part of the California GAMA-PBP, a cooperative project between the USGS and the California State Water Resources Control Board. Samples were collected between 2005 and 2016 at these wells, and the data for these samples have been published in a series of data series reports (appendix 3, table 3.1). The data also are available from USGS (2018). Wells in the cvalpas1 ranged from about 80 to $1,500 \mathrm{ft}$ deep, with a median well depth of about $400 \mathrm{ft}$ (appendix 2, table 2.1).

\section{Decadal Trends Networks-Land-Use Study Networks}

The LUS networks are designed to facilitate analysis of land-use effects on shallow groundwater quality. Wells in LUS networks are sampled once per decade to assess temporal trends in water quality. Most of the LUS networks were sampled in the 1990s and again in the 2000s (USGS, 2020a). The samples collected during the period described in this report represent the third decadal sampling for most of these networks. Wells in LUS networks typically are shallow and screened near the water table to allow sampling of recently recharged groundwater that may demonstrate chemical characteristics indicative of the surrounding land use. The LUS areas are determined by the intersection of areal extents of the primary aquifer and a targeted overlying land use (Lapham and others, 1995). Data from the following LUS networks are included in this report: Connecticut, Housatonic, and Thames River Basins urban LUS network (connlusrc1; fig. 9) near Harford, Connecticut; Eastern Iowa Basins agricultural LUS network (eiwaluscr1; fig. 10); Long Island-New Jersey coastal drainages urban LUS network (linjlusrc1; fig. 11) near Glassboro, New Jersey; Mississippi Embayment urban LUS network (miselusrc1; fig. 12) near Memphis, Tennessee; Ozark Plateaus agricultural LUS network (ozrklusag2a; fig. 13); Puget Sound drainages agricultural LUS network (pugtluscr1; fig. 14); Sacramento River Basin agricultural LUS network (sacrluscr1; fig. 15); Sacramento River Basin urban LUS network (sacrlusrc1; fig. 16); Santee River Basin and coastal drainages agricultural LUS network (santluscr1; fig. 17); South Central Texas urban LUS network (sctxlusrc1; fig. 18) near San Antonio, Texas; Upper Mississippi River Basin agricultural LUS network (umisluscr1; fig. 19); and Upper Snake River Basin agricultural LUS network (usnkluscr3; fig. 20).

\section{Connecticut, Housatonic, and Thames River Basins Urban Land-Use Study Network (connlusrc1)}

The Connecticut, Housatonic, and Thames River Basins urban LUS network (connlusrc1; fig. 9) was used to characterize the quality of shallow groundwater in surficial glacial aquifers within urban areas of the study unit in Connecticut and southwestern Massachusetts. The Pleistocene- to Holocene-age surficial aquifers are composed of unconsolidated glacial and fluvial deposits, which are thickest in buried bedrock valleys. Precambrian to early Mesozoic bedrock underlies the glacial aquifer. Typical yields of wells in glacial aquifers are 10 to 400 gallons per minute (Olcott, 1995), and the glacial aquifer supplies groundwater for drinking water and other uses. Urban development, including residential, commercial, and other developed land uses, is predominant, with small agricultural and forest areas. The study area covers about $230 \mathrm{mi}^{2}$. 


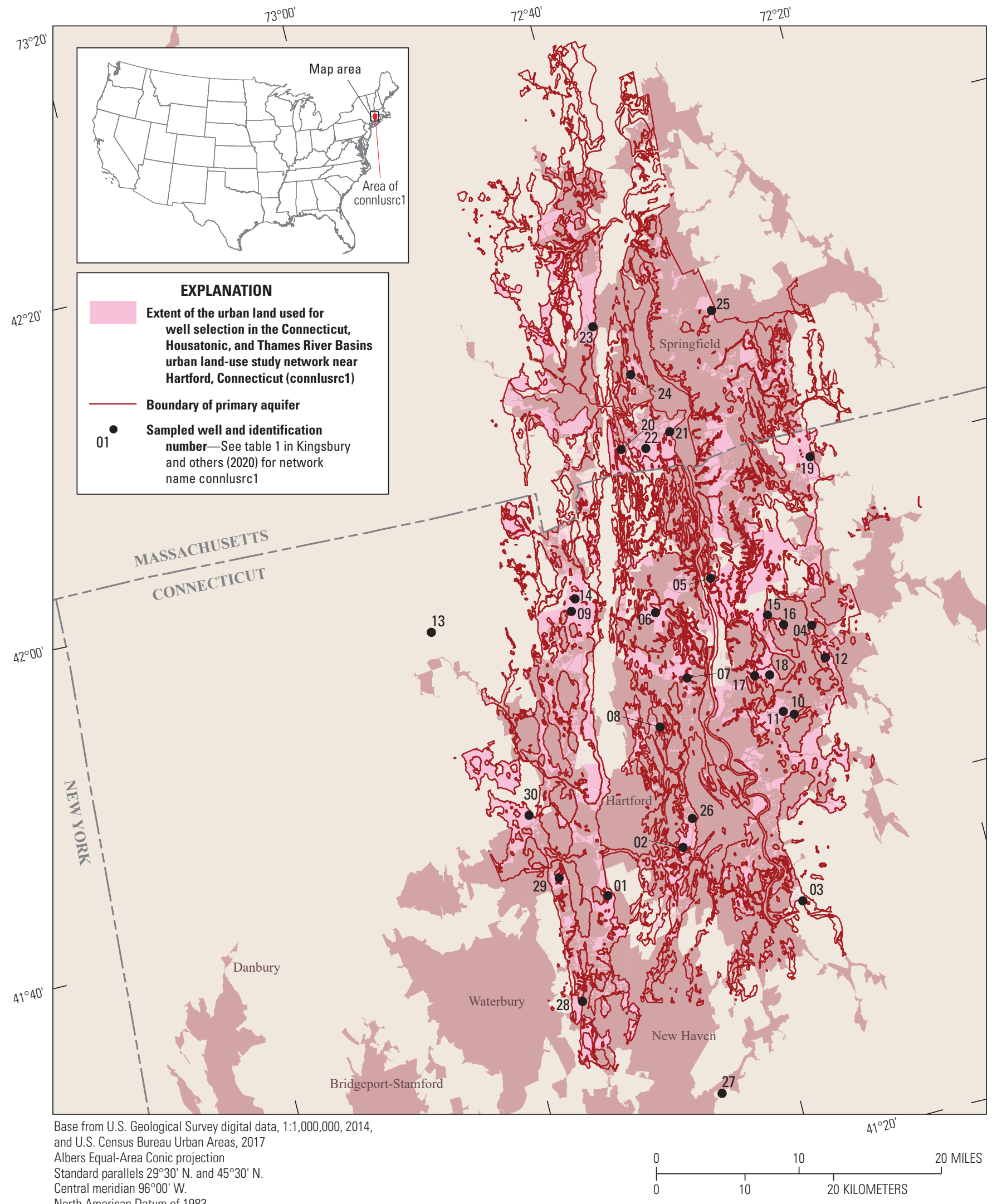

Figure 9. Study area and wells sampled as part of the Connecticut, Housatonic, and Thames River Basins urban land-use study network (connlusrc1) near Hartford, Connecticut, for the U.S. Geological Survey National Water-Quality Assessment Project. 


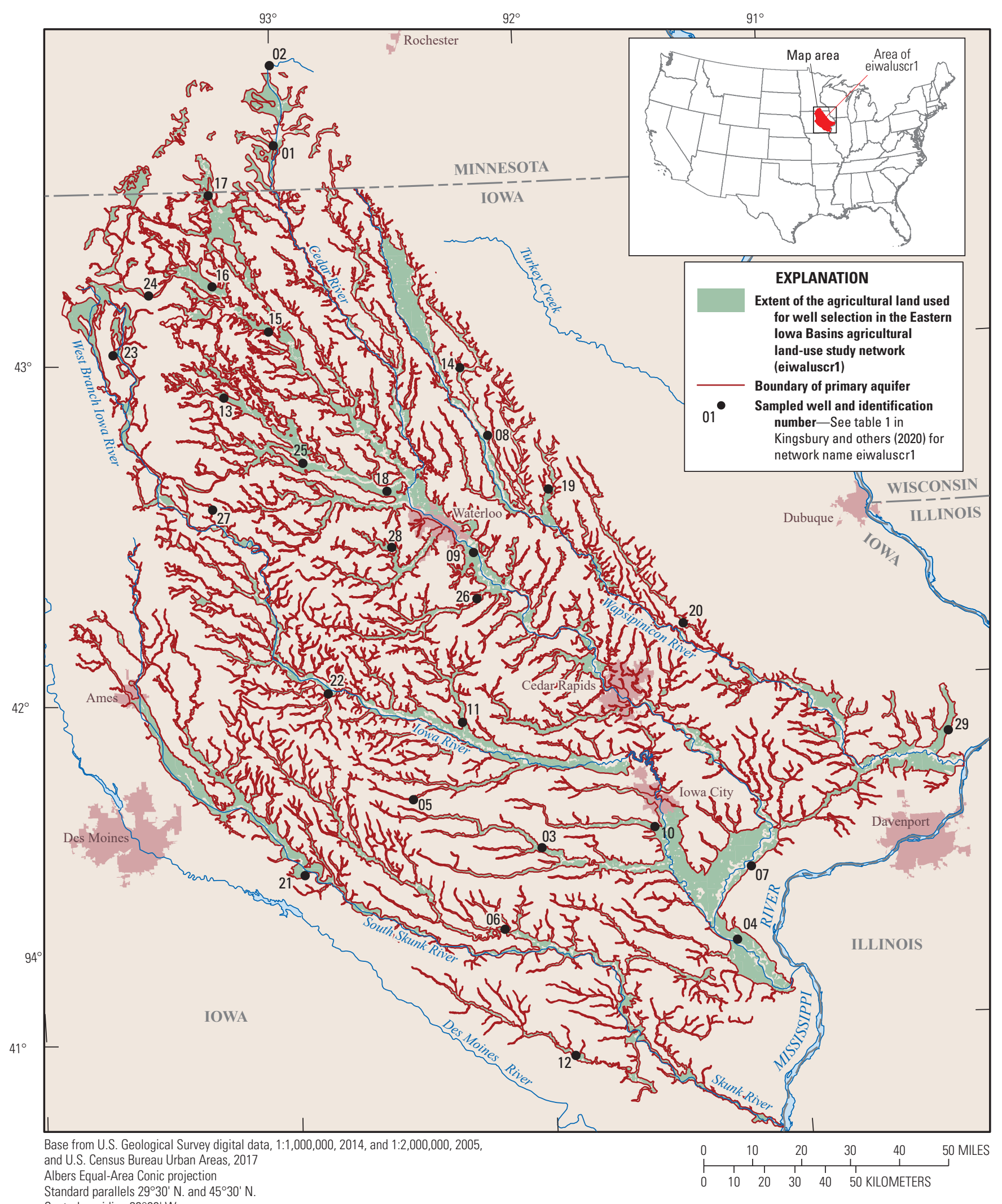

Standard parallels $29^{\circ} 30^{\prime} \mathrm{N}$. and $45^{\circ} 30^{\prime} \mathrm{N}$.

Central meridian $96^{\circ} 00^{\prime} \mathrm{W}$.

North American Datum of 1983

Figure 10. Study area and wells sampled as part of the Eastern lowa Basins agricultural land-use study network (eiwaluscr1) for the U.S. Geological Survey National Water-Quality Assessment Project. 


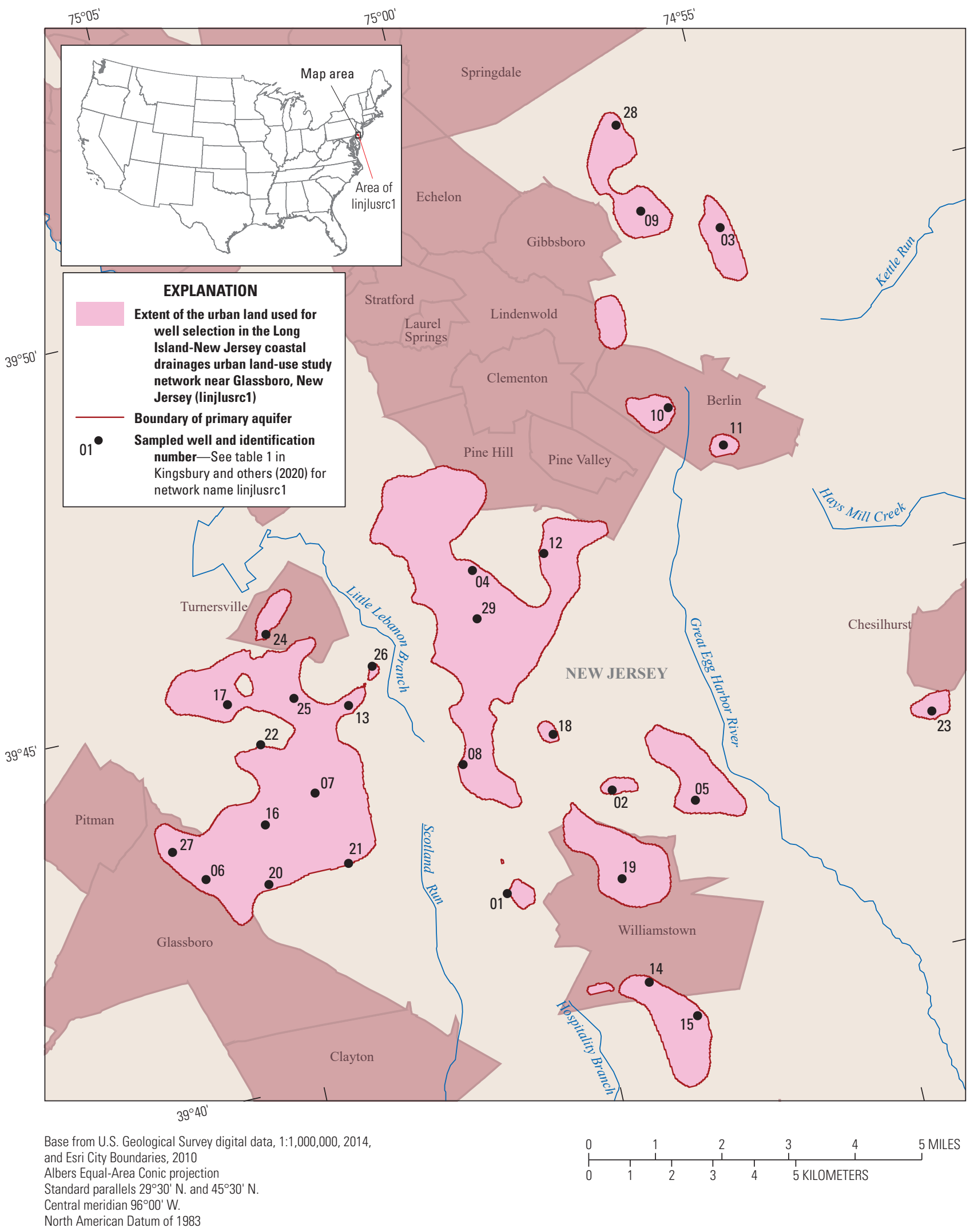

Figure 11. Study area and wells sampled as part of the Long Island-New Jersey coastal drainages urban land-use study network (linjlusrc1) near Glassboro, New Jersey, for the U.S. Geological Survey National Water-Quality Assessment Project. 


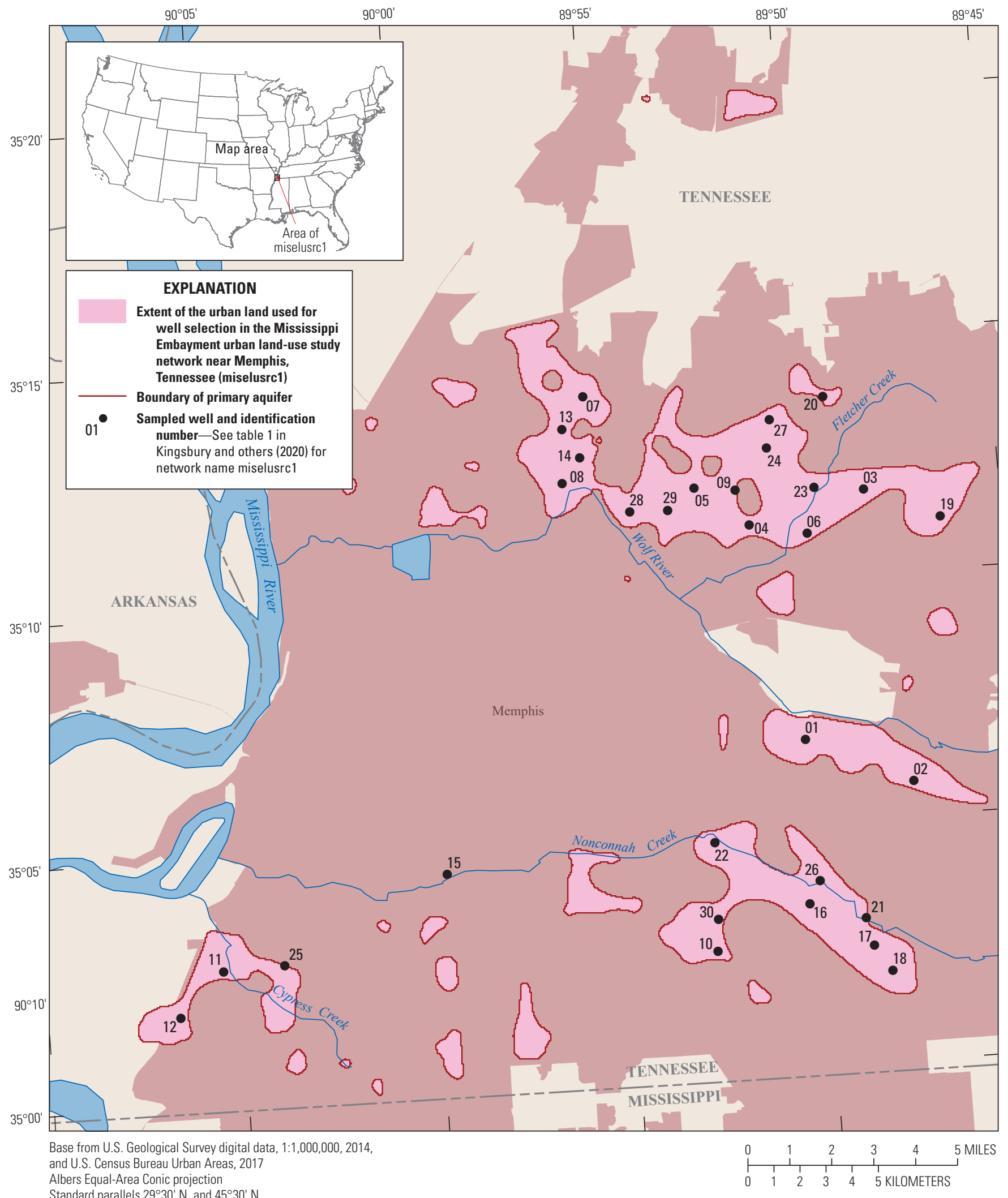

Standard parallels

Central meridian $96^{\circ} 00^{\prime} \mathrm{W}$.

North American Datum of 1983

Figure 12. Study area and wells sampled as part of the Mississippi Embayment urban land-use study network (miselusrc1) near Memphis, Tennessee, for the U.S. Geological Survey National Water-Quality Assessment Project. 


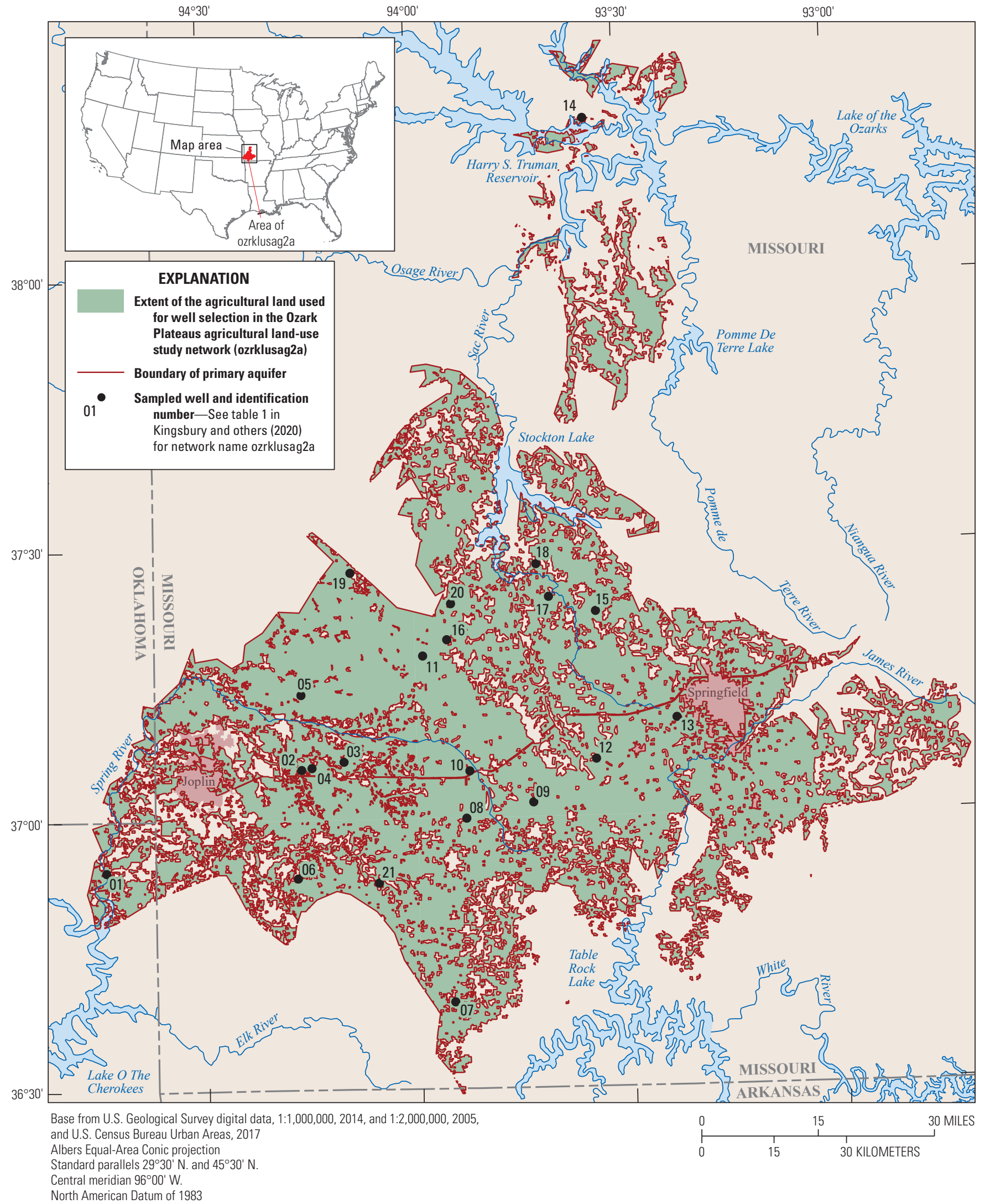

Figure 13. Study area and wells sampled as part of the Ozark Plateaus agricultural land-use study network (ozrklusag2a) for the U.S. Geological Survey National Water-Quality Assessment Project. 


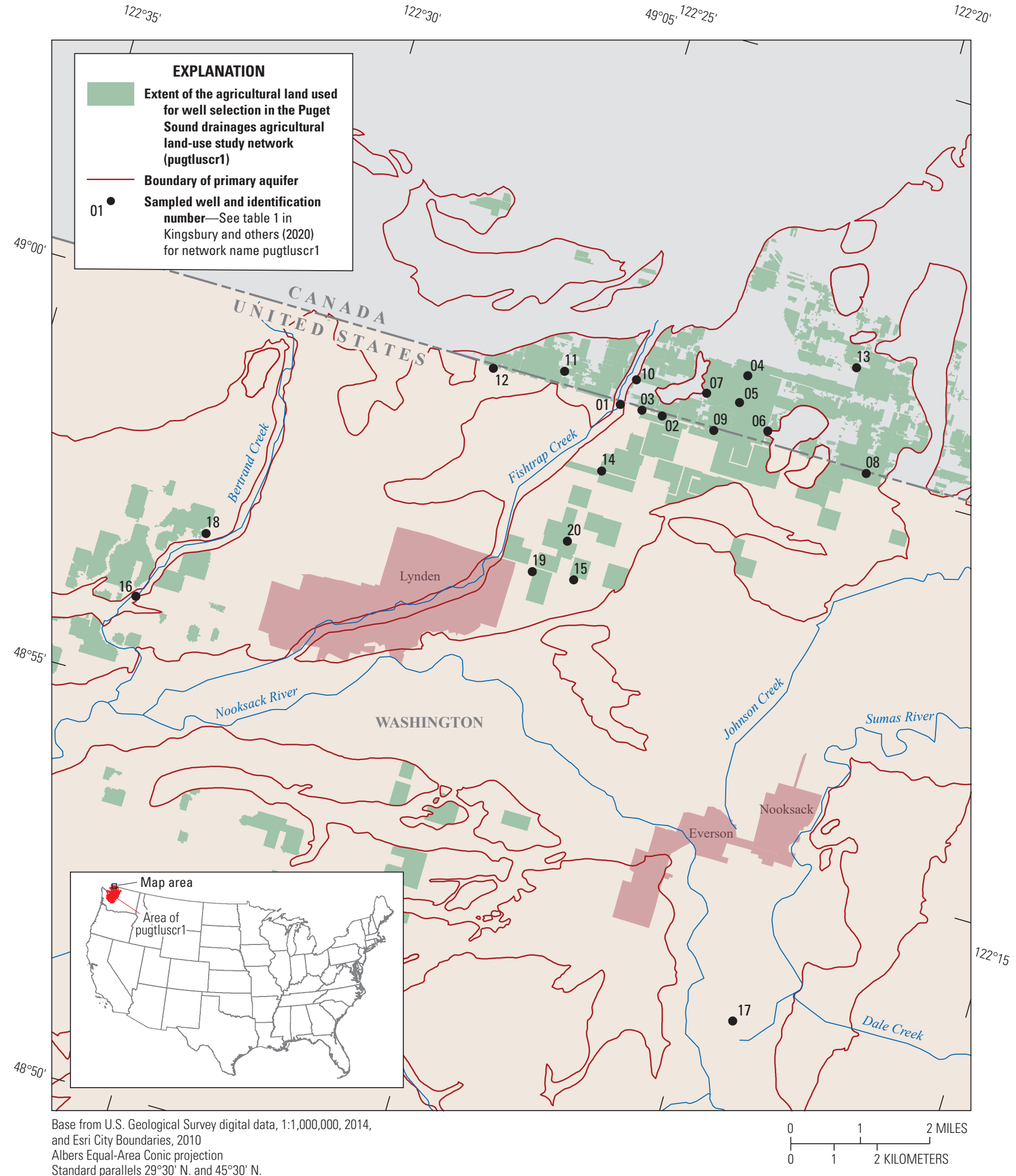

Standard parallels $29^{\circ} 30^{\prime} \mathrm{N}$. and $45^{\circ} 30^{\prime} \mathrm{N}$.

Central meridian $96^{\circ} 00^{\prime} \mathrm{W}$.

North American Datum of 1983

Figure 14. Study area and wells sampled as part of the Puget Sound drainages agricultural land-use study network (pugtluscr1) for the U.S. Geological Survey National Water-Quality Assessment Project. 


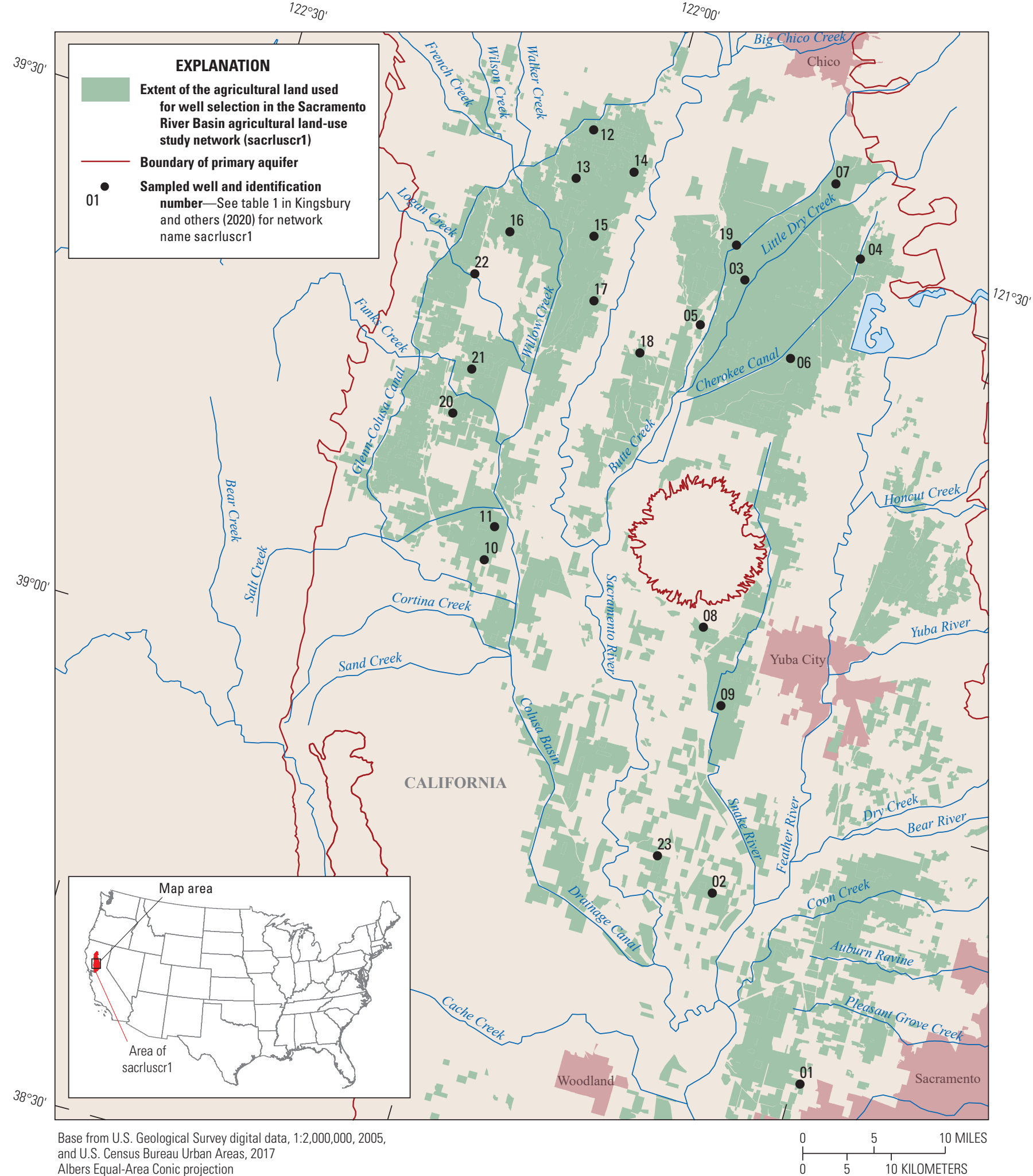

and U.S. Census Bureau Urban Areas, 2017

Standard parallels $29^{\circ} 30^{\prime} \mathrm{N}$. and $45^{\circ} 30^{\prime} \mathrm{N}$.

Central meridian $96^{\circ} 00^{\prime} \mathrm{W}$.

North American Datum of 1983

Figure 15. Study area and wells sampled as part of the Sacramento River Basin agricultural land-use study network (sacrluscr1) for the U.S. Geological Survey National Water-Quality Assessment Project. 


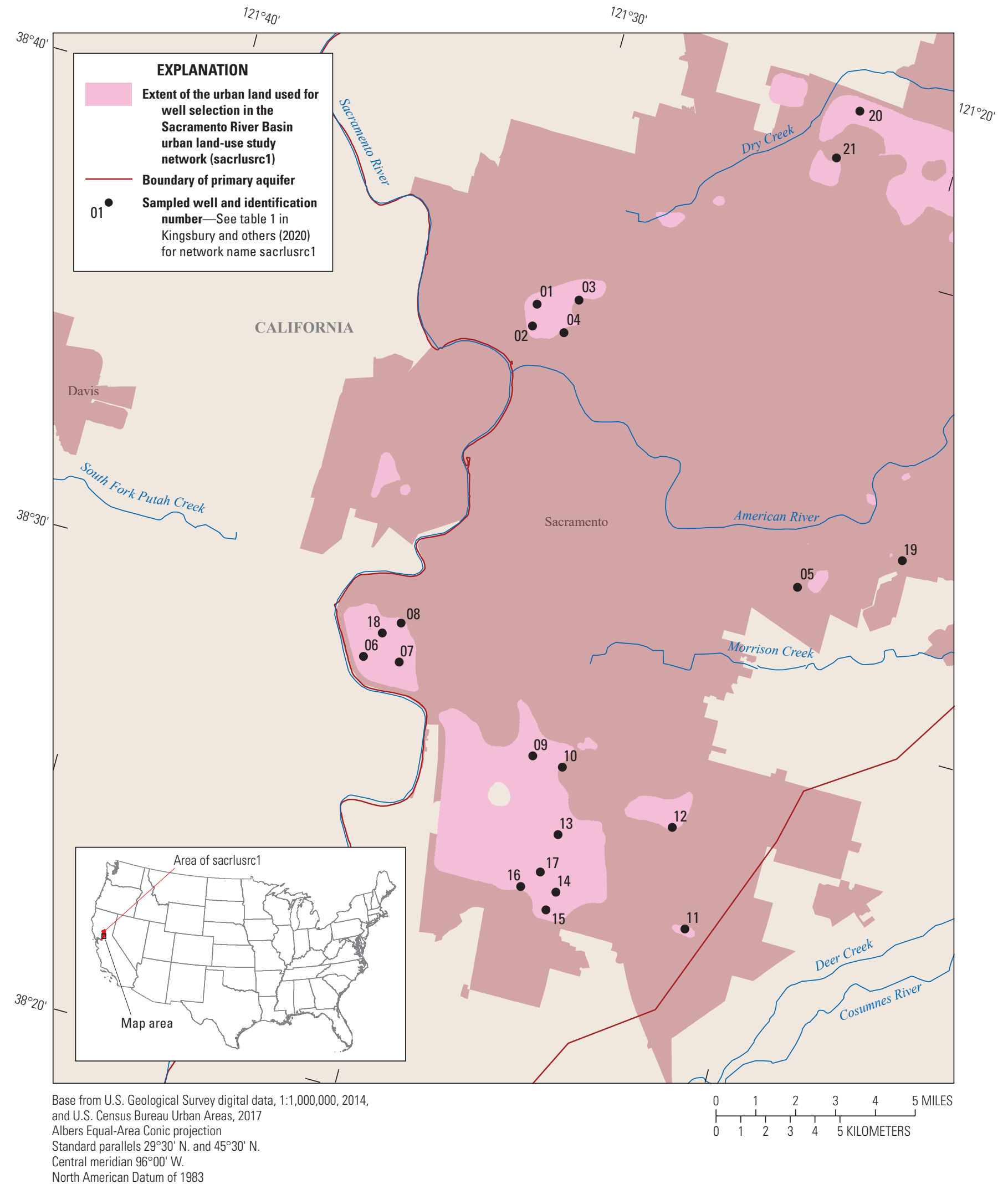

Figure 16. Study area and wells sampled as part of the Sacramento River Basin urban land-use study network (sacrlusrc1) near Sacramento, California, for the U.S. Geological Survey National Water-Quality Assessment Project. 


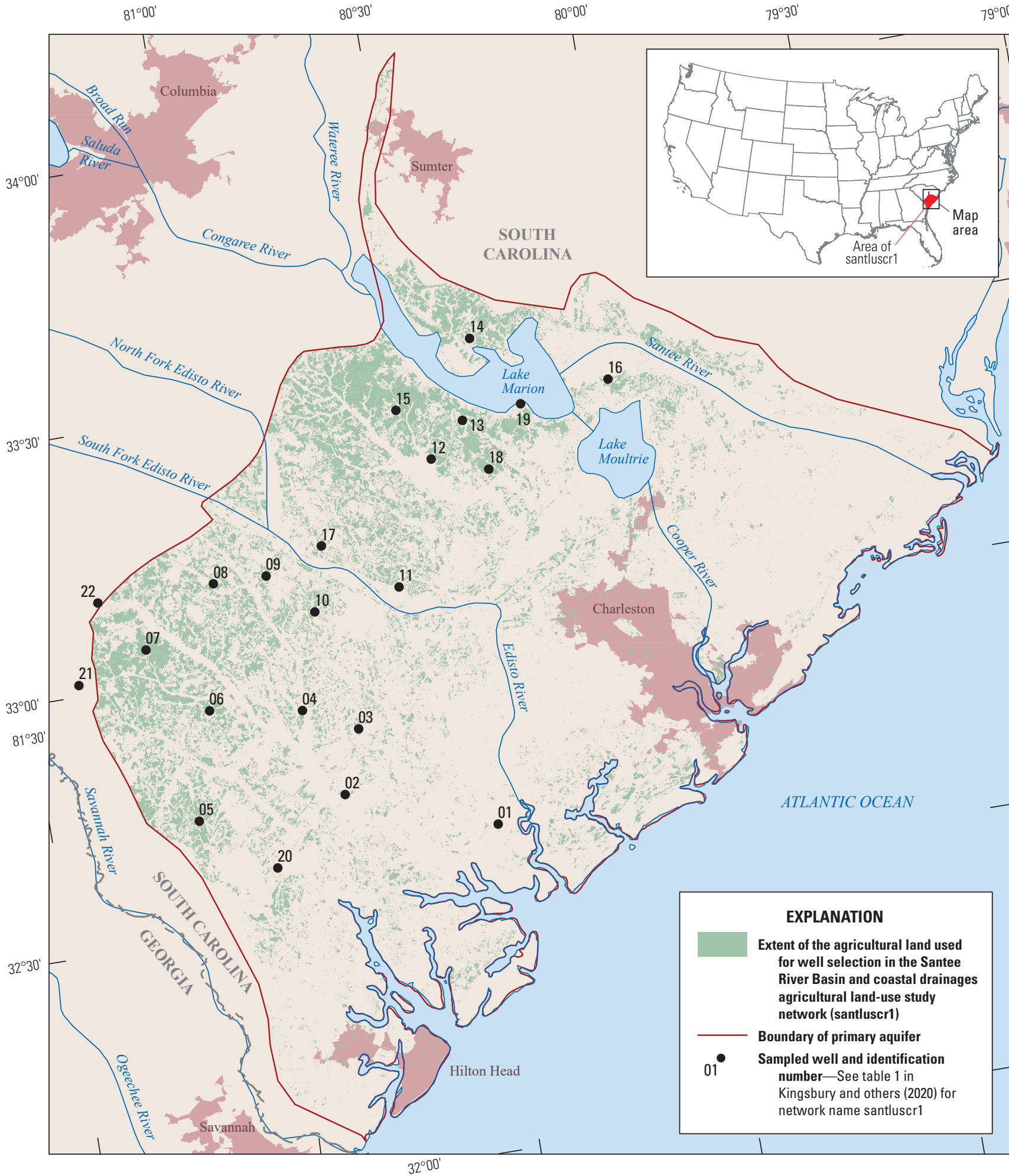

Base from U.S. Geological Survey digital data, 1:1,000,000, 2014, and 1:10,000,000, 2014 U.S. Census Bureau Urban Areas, 2017 Albers Equal-Area Conic projection

Standard parallels $29^{\circ} 30^{\prime} \mathrm{N}$. and $45^{\circ} 30^{\prime} \mathrm{N}$.

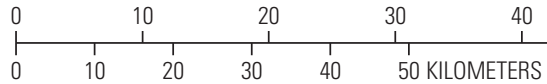

50 MILES

Central meridian $96^{\circ} 00^{\prime} \mathrm{W}$.

North American Datum of 1983

Figure 17. Study area and wells sampled as part of the Santee River Basin and coastal drainages agricultural land-use study network (santluscr1) for the U.S. Geological Survey National Water-Quality Assessment Project. 


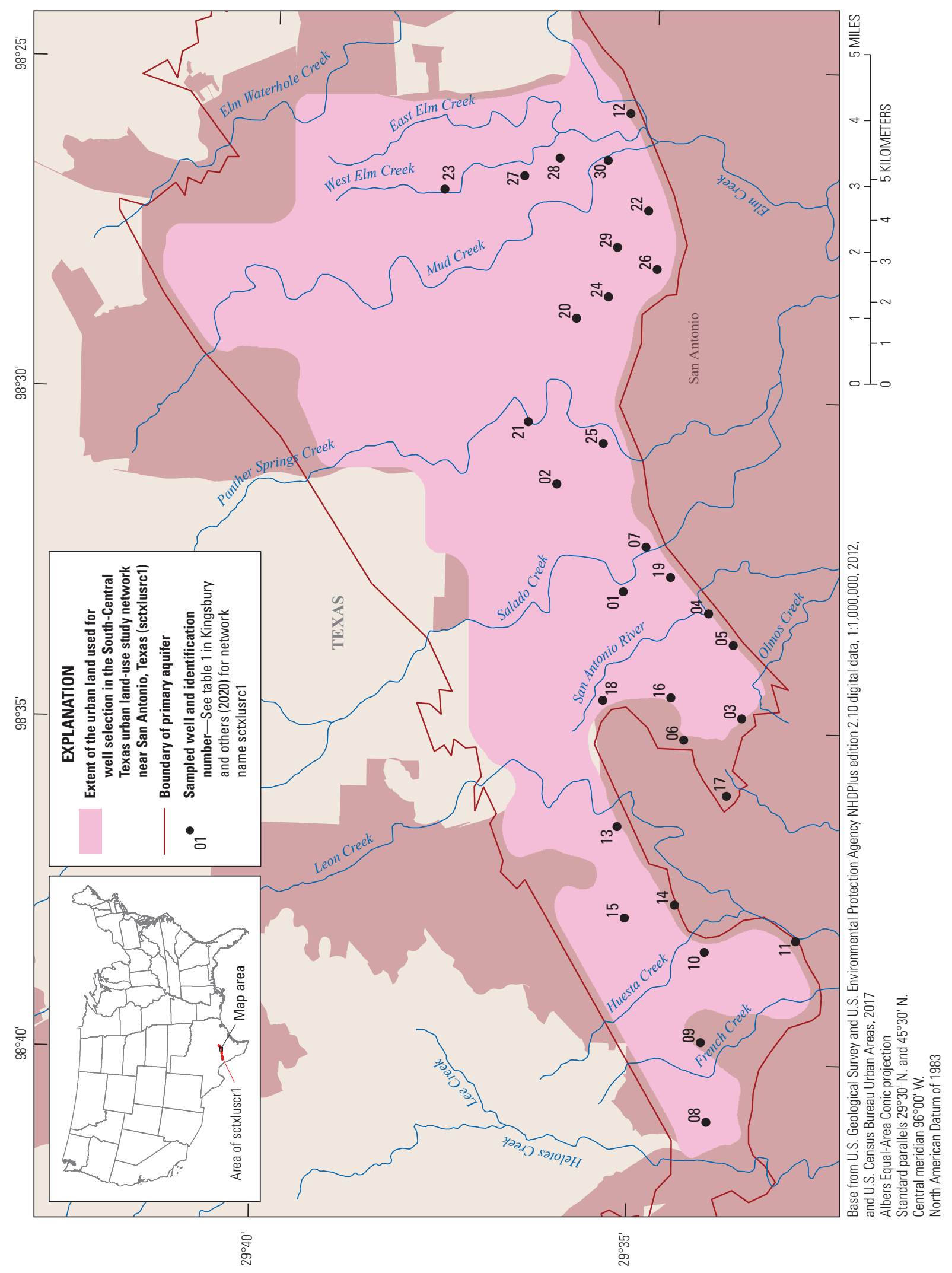

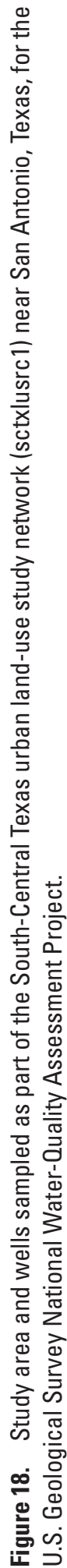




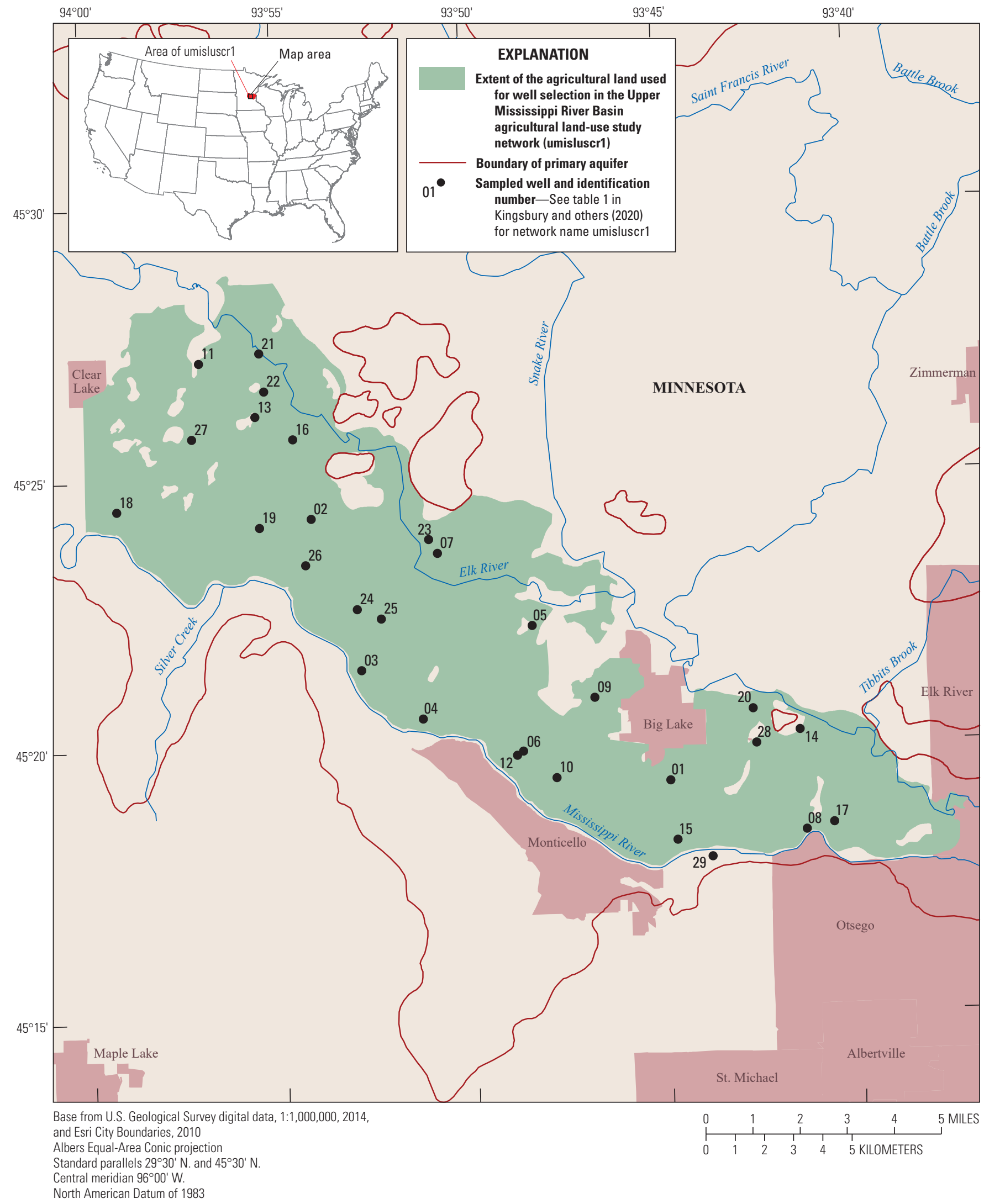

Figure 19. Study area and wells sampled as part of the Upper Mississippi River Basin agricultural land-use study network (umisluscr1) for the U.S. Geological Survey National Water-Quality Assessment Project. 


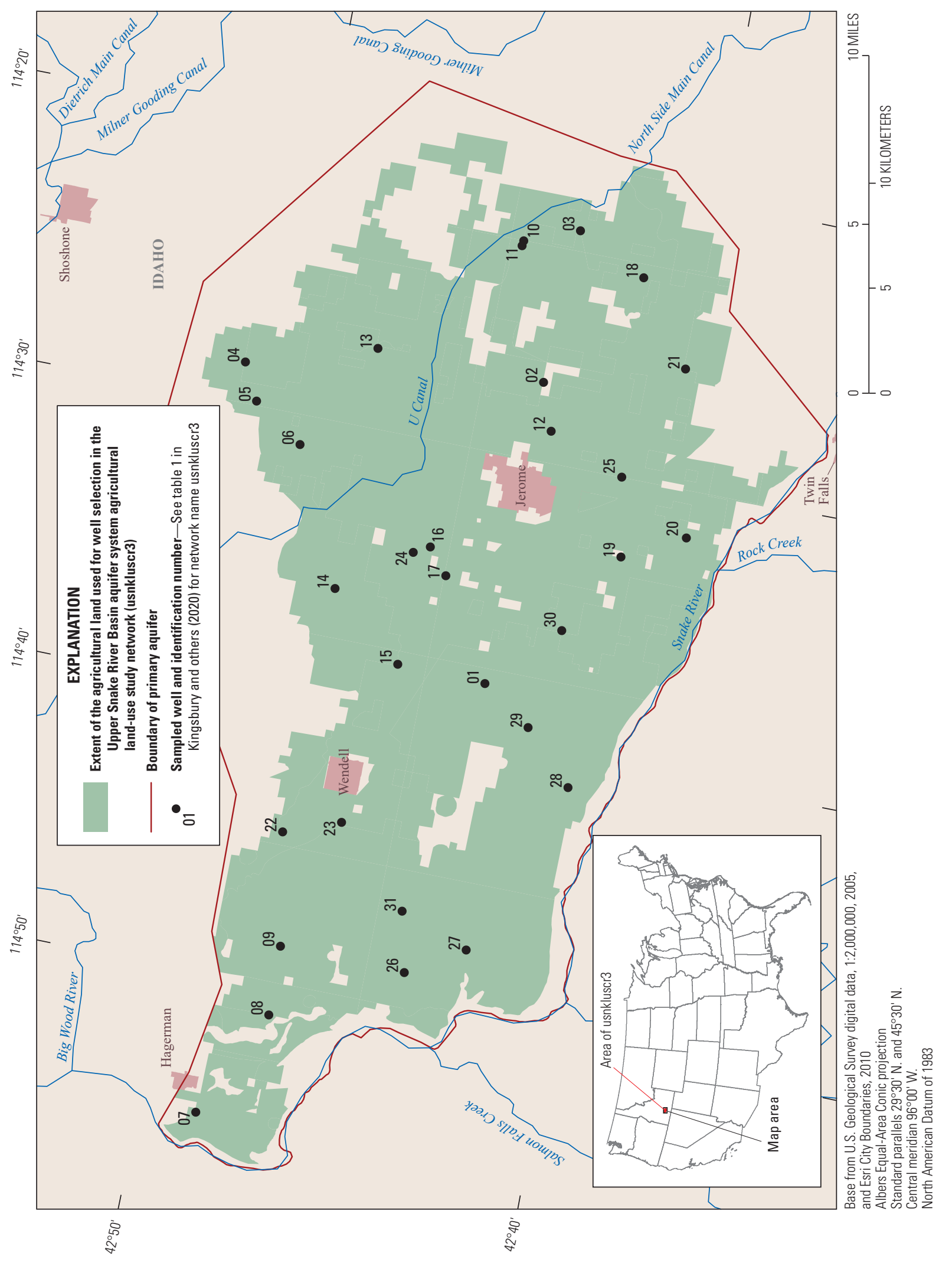

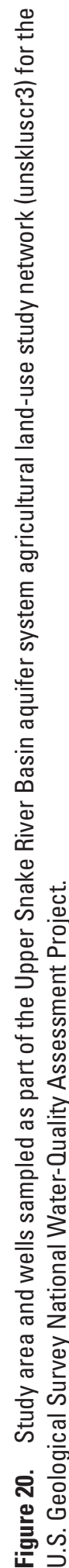


The connlusrc 1 consists of 30 shallow monitoring wells completed immediately below the water table at depths from 8 to $70 \mathrm{ft}$, with a median of $20 \mathrm{ft}$ (appendix 2, table 2.1). Open intervals were 2-5 ft (appendix 2, table 2.2). Samples for the current phase of monitoring were collected April through September 2017, and these data are presented in Kingsbury and others (2020). Wells from the connlusrc1 network were previously sampled in 2003 (USGS, 2020a).

\section{Eastern lowa Basins Agricultural Land-Use Study Network (eiwaluscr1)}

The Eastern Iowa Basins agricultural LUS network (eiwaluscr1; fig. 10) was used to assess the quality of shallow groundwater in alluvial stream-valley aquifers in the Wapsipinicon, Cedar, Iowa, and Skunk River Basins, tributaries to the Mississippi River. Surficial alluvial deposits are present in Holocene-age river valleys and commonly consist of 30 to $100 \mathrm{ft}$ of unconsolidated sands and gravels interbedded with silts and clays (Steinhilber and Horick, 1970; Wahl and others, 1978; Olcott, 1992). The surficial permeable sands and gravels, shallow depth to the water table, and the absence of confining units make the study unit alluvial aquifers susceptible to contamination from land-use activities. Surficial alluvial aquifers and Quaternary-age buried-channel and glacial-outwash deposits supply a substantial part of groundwater used in the study area. The study area covers about 3,600 $\mathrm{mi}^{2}$, and row-crop agriculture is the dominant land use (Savoca and others, 2000).

The eiwaluscr1 consists of 29 shallow monitoring wells completed immediately below the water table at depths from 12 to $28 \mathrm{ft}$, with a median of $18 \mathrm{ft}$ (appendix 2, table 2.1). Open intervals were all $5 \mathrm{ft}$ (appendix 2, table 2.2). Samples for the current phase of monitoring were collected May through August 2017, and these data are presented in Kingsbury and others (2020). Wells from the eiwaluscr1 network were previously sampled in 1998 and 2007 (USGS, 2020a).

\section{Long Island-New Jersey Coastal Drainages Urban Land-Use Study Network (linjlusrc1)}

The Long Island-New Jersey coastal drainages urban LUS network (linjlusrc1; fig. 11) was designed to characterize urban land-use effects on shallow groundwater quality in an area overlying the Northern Atlantic Coastal Plain aquifer system in the Glassboro, N.J., area. The Long Island-New Jersey coastal drainages aquifer system (linjlusrc1 is in the southern end) underlies an area of about $6,000 \mathrm{mi}^{2}$ (Stackelberg and Ayers, 1994) and is home to about 15 million people in parts of New York and New Jersey (Ayers and others, 2000) and the cities of New York, New York, and Trenton, N.J., overlying the aquifer system. The Northern Atlantic Coastal Plain aquifer system consists of unconsolidated to partly consolidated sediments that range in age from Early Cretaceous to Holocene (Trapp and Horn, 1997; Masterson and others, 2013; Denver and others, 2014). The sedimentary layers thicken and deepen toward the Atlantic Coast, where they reach a maximum thickness of about $10,000 \mathrm{ft}$.

The linjlusrc1 consists of 29 monitoring wells completed in the unconfined surficial Kirkwood-Cohansey aquifer system in the 400-mi2 Glassboro study area in southern New Jersey (Ayers and others, 2000). Wells were completed at depths from 14 to $71 \mathrm{ft}$, with a median of $29 \mathrm{ft}$ (appendix 2, table 2.1), and open intervals were generally 2-10 ft (appendix 2, table 2.2). Wells from the linjluscr1 network were previously sampled in 1996 and 2005 (USGS, 2020a). Samples for the current phase of monitoring were collected during August and November 2017.

\section{Mississippi Embayment Urban Land-Use Study Network (miselusrc1)}

The Mississippi Embayment urban LUS network (miselusrc1; fig. 12) was designed to characterize the quality of shallow groundwater in the areas developed since about the 1980s in Memphis, Tenn. The study area includes about $47 \mathrm{mi}^{2}$. Most of the wells were completed in the terrace deposits aquifer, a water-table aquifer that is separated by a lower confining unit from the Memphis aquifer, the primary source of drinking water. The terrace deposits consist of unconsolidated Pliocene- to Pleistocene-age sand and gravel and generally are about $100 \mathrm{ft}$ thick (Parks, 1990). In the eastern part of the study area, the terrace deposits are dry where the confining unit is thin or absent, and wells were completed in the upper part of the Memphis aquifer.

The miselusrc 1 consists of 30 shallow monitoring wells with depths that range from 33 to $124 \mathrm{ft}$, with a median of $66 \mathrm{ft}$ (appendix 2, table 2.1). Open intervals for most of the wells were $10 \mathrm{ft}$ (appendix 2, table 2.2). Wells from the miselusrc1 network were previously sampled in 1997 and 2006 (USGS, 2020a). Samples for the current phase of monitoring were collected April through June 2017, and these data are presented in Kingsbury and others (2020).

\section{Ozark Plateaus Agricultural Land-Use Study Network (ozrklusag2a)}

The Ozark Plateaus agricultural LUS network (ozrklusag2a; fig. 13) was designed to characterize the effects of agricultural activities on groundwater in a karst aquifer system in southwestern Missouri and northwestern Arkansas. The study area covers about 3,300 $\mathrm{mi}^{2}$. The Ozark Plateaus aquifer system consists of three regional aquifers that are separated by confining units (Miller and Appel, 1997; Renken, 1998). The primary lithologies of the geologic formations making up the aquifers are limestone and dolomite. Wells in this network are 
primarily in the uppermost Springfield aquifer and the intermediate Ozark aquifer, which are the primary water-bearing units in this aquifer system.

The ozrklusag2a consists of 21 (primarily) domestic wells with depths ranging from 45 to $585 \mathrm{ft}$, with a median of $200 \mathrm{ft}$ (appendix 2, table 2.1). Open intervals generally were not available for wells in this network (appendix 2, table 2.2). Wells from the ozrklusag2a network were previously sampled in 1995 and 2007 (USGS, 2020a).Samples for the current phase of monitoring were collected during June and July 2017.

\section{Puget Sound Drainages Agricultural Land-Use Study Network (pugtluscr1)}

The Puget Sound drainages agricultural LUS network (pugtluscr1; fig. 14) was designed to characterize the effects of agriculture on shallow groundwater quality in a part of the glacial aquifer system. The study area of $12 \mathrm{mi}^{2}$ is part of the Puget Sound lowlands in northern Whatcom County in northern Washington (United States) and southwestern British Columbia (Canada). The unconfined Fraser aquifer, composed of coarse-grained glacial sediments, underlies the study area and is overlain by intensive row crops, particularly raspberry fields (Inkpen and others, 2000).

The pugtluscr1 network includes 20 wells (predominantly monitoring wells) that were sampled in July and August 2018. The wells range in depth from 18 to $96 \mathrm{ft}$ (median of $29 \mathrm{ft}$ ) with small open intervals from 3 to $10 \mathrm{ft}$ (median of $5 \mathrm{ft}$ ). Wells in the pugtluscr1 network were previously sampled in 1998 and 2006 (USGS, 2020a).

\section{Sacramento River Basin Agricultural Land-Use Study Network (sacrluscr1)}

The Sacramento River Basin agricultural LUS network (sacrluscr1; fig. 15) was designed to characterize shallow groundwater quality underlying agricultural land use in the rice growing regions of the central part of the Sacramento Valley, which is in the northern part of the Central Valley aquifer system of California. The study area includes about $860 \mathrm{mi}^{2}$. The Sacramento Valley groundwater basin is dominated by agricultural land use with rice as the largest crop acreage, which is primarily irrigated using surface water; rice pesticides have been previously detected in surface water and groundwater (Dawson, 2001; Bennett and others, 2011). The Sacramento River Basin is a structural trough surrounded by the Sierra Nevada, Cascade, and Coast Ranges mountains and is composed of their eroded sediments (Dawson, 2001).

The sacrluscr 1 network includes 23 monitoring wells that were sampled in July 2017. The wells range in depth from 29 to $50 \mathrm{ft}$ (appendix 2, table 2.1) with a small open interval of $5 \mathrm{ft}$ (appendix 2, table 2.2). Wells in the sacrluscr1 network were previously sampled in 1997 and 2006 (USGS, 2020a).

\section{Sacramento River Basin Urban Land-Use Study Network (sacrlusrc1)}

The Sacramento River Basin urban LUS network (sacrlusrc1; fig. 16) was designed to characterize shallow groundwater quality in the northern part of the Central Valley aquifer system of California, specifically in the southeastern Sacramento Valley. The study area is about $38 \mathrm{mi}^{2}$ and is overlain by primarily residential areas developed between 1975 and 1993 in the Sacramento metropolitan area (Shelton, 2005). The hydrogeologic framework consists of heterogeneous alluvial deposits eroded from the Sierra Nevada mountain ranges to the east and the Coast Ranges to the west (Bennett and others, 2011). Shallow groundwater in this area is thought to be hydraulically connected to surface water used for public supply (Domagalski and others, 1998).

The sacrlusrc1 network includes 21 monitoring wells that range in depth from 37 to $166 \mathrm{ft}$ (median of $71 \mathrm{ft}$ ). The wells have small open intervals ranging from 5 to $15 \mathrm{ft}$, with a median of $10 \mathrm{ft}$. The network was sampled in August 2017. Wells in the sacrlusrc1 network were previously sampled in 1998 and 2005 (USGS, 2020a).

\section{Santee River Basin and Coastal Drainages Agricultural Land-Use Study Network (santluscr1)}

The Santee River Basin and coastal drainages agricultural LUS network (santluscr1; fig. 17), with a study area of about $970 \mathrm{mi}^{2}$, was designed to characterize groundwater quality underlying agricultural land use in the surficial aquifer system in the South Carolina coastal plain. The aquifer is relatively thin, generally $50 \mathrm{ft}$ or less in thickness, and is composed of sandy marine terrace deposits of Pleistocene and Holocene age (Miller, 1990).

The santluscr 1 network includes 22 monitoring wells that range in depth from 13 to $30 \mathrm{ft}$, with a median of $18 \mathrm{ft}$ (appendix 2, table 2.1). Open intervals for these wells are between 5 and $15 \mathrm{ft}$, with most of them having 5 -ft open intervals (appendix 2, table 2.2). Samples for the current phase of monitoring were collected during July and November 2018.

\section{South-Central Texas Urban Land-Use Study Network (sctxlusrc1)}

The South-Central Texas urban LUS network (sctxlusrc1; fig. 18), with a study area of about $60 \mathrm{mi}^{2}$, was designed to characterize groundwater quality in parts of the unconfined Edwards aquifer with residential and commercial land use near San Antonio, Tex. The Edwards aquifer-locally referred to as the Edwards (Balcones Fault Zone) aquifer-consists of partially dissolved and highly permeable limestone of the Georgetown Formation and the Edwards Group. 
The sctxlusrc1 network includes 30 monitoring wells that range in depth from 180 to $320 \mathrm{ft}$ (median of $261 \mathrm{ft}$ ) (appendix 2, table 2.1). Open intervals range from about 60 to $120 \mathrm{ft}$, with a median of $80 \mathrm{ft}$ (appendix 2, table 2.2). Samples for the current phase of monitoring were collected from October to December 2017. Wells from the sctxlusrc1 network were previously sampled in 1998 and 2006 (USGS, 2020a).

\section{Upper Mississippi River Basin Agricultural Land-Use Study Network (umisluscr1)}

The Upper Mississippi River Basin agricultural LUS network (umisluscr1; fig. 19) was used to characterize the quality of groundwater in the Anoka Sand Plain aquifer within an agricultural area of the Upper Mississippi study unit. The part of the Anoka Sand Plain aquifer that underlies the study area consists primarily of terrace deposits and, to a lesser extent, floodplain alluvium (Ruhl and others, 2000). Deposits generally range in thickness from 15 to $115 \mathrm{ft}$. Medium to coarse sand is interbedded with thin layers of clay, silt, silty sand, and gravel (Helgesen and Lindholm, 1977; Lindholm, 1980). The depth to the water table is shallow and hydraulic conductivity is high (50 to as much as 1,000 feet per day; Anderson, 1993), making the aquifer vulnerable to land-surface sources of contamination. Surficial aquifers, buried sand and gravel aquifers, and underlying bedrock aquifers in the study area are used for drinking water and irrigation (Andrews and others, 1998). In previous decadal sampling events, the land use in the study area was predominantly row-crop agricultural. Current (2011) land use (Homer and others, 2015) has changed to only about 50 -percent agricultural, and the remainder is urban or residential. The study area covers about $1,700 \mathrm{mi}^{2}$.

The umisluscr 1 consists of 29 shallow monitoring wells completed immediately below the water table at depths from 8 to $63 \mathrm{ft}$, with a median of $25 \mathrm{ft}$ (appendix 2, table 2.1). Open intervals generally were $5 \mathrm{ft}$ (appendix 2, table 2.2). Samples for the current phase of monitoring were collected May through August 2018, and these data are presented in Kingsbury and others (2020). Wells from the umisluscr1 network were previously sampled in 1998 and 2006 (USGS, 2020a).

\section{Upper Snake River Basin Agricultural Land-Use Study Network (usnkluscr3)}

The Upper Snake River Basin agricultural LUS network (usnkluscr3; fig. 20), with a study area of about $270 \mathrm{mi}^{2}$, was designed to characterize groundwater quality underlying agricultural land use in the East Snake River Plain aquifer in the Upper Snake River Basin in southern Idaho. The aquifer is composed of a series of Quaternary basalt flows that are vesicular and broken and able to transmit large volumes of water (Whitehead, 1992). The study area is characterized by a history of elevated nitrate concentrations in groundwater and is predominantly an area of groundwater-sourced irrigated agriculture (Rupert, 1997; Skinner and Donato, 2003).

The usnkluscr3 network includes 31 wells, mostly used for domestic supply. The wells range in depth from 55 to $600 \mathrm{ft}$ (median of $223 \mathrm{ft}$ ) (appendix 2, table 2.1) with a large range of open intervals (from 15 to $450 \mathrm{ft}$ ), with a median of $120 \mathrm{ft}$ (appendix 2, table 2.2). Samples for the current phase of monitoring were collected during June 2017. Wells in this network were previously sampled in 1994 and 2005 (USGS, 2020a).

\section{Decadal Trends Networks-Major Aquifer Study Networks}

The MAS networks were designed to characterize the water quality of the resource used for domestic supply. The MAS networks generally consist of domestic-supply wells but also may include public-supply or other types of wells. Domestic-supply wells typically draw groundwater from shallower depths of the aquifer than do public-supply wells. Additionally, domestic-supply wells tend to draw smaller volumes of water from the aquifer than do public-supply wells. The MAS areas are determined by the areal extent of the primary aquifer and physiography and are designed to assess the condition of groundwater quality in the most heavily used aquifer in the study areas during the first decade of sampling (Koterba and others, 1995; Lapham and others, 1995). Wells in MAS networks are sampled once per decade to assess temporal trends in water quality. Most of the MAS networks were sampled in the 1990s and again in the 2000s (USGS, 2020a). The samples collected during the period described in this report represent the third decadal sampling for most of these networks. Data from the following MAS networks are included in this report: Central Arizona Basins MAS network (cazbsus 1a; fig. 21); Connecticut, Housatonic, and Thames River Basins MAS network (connsus2; fig. 22); Eastern Iowa Basins MAS network (eiwasus2; fig. 23); Long Island-New Jersey coastal drainages MAS network (linjsus2; fig. 24); Lower Illinois River Basin MAS network (lirbsus1; fig. 25); Santee River Basin and coastal drainages MAS network (santsus2; fig. 26); South-Central Texas MAS network (sctxsus1; fig. 27), Upper Illinois River Basin MAS network (uirbsus3; fig. 28), and the Upper Mississippi River Basin MAS network (umissus3; fig. 29).

\section{Central Arizona Basins Major Aquifer Study Network (cazbsus1a)}

The Central Arizona Basins MAS network (cazbsus1a; fig. 21) was designed to characterize the quality of groundwater in part of the Basin and Range basin-fill aquifers. The study area of about 1,000 $\mathrm{mi}^{2}$ encompasses urban and agricultural land uses on the western side of Phoenix, Arizona, in the West Salt River Valley in the Basin and Range lowlands. Phoenix 


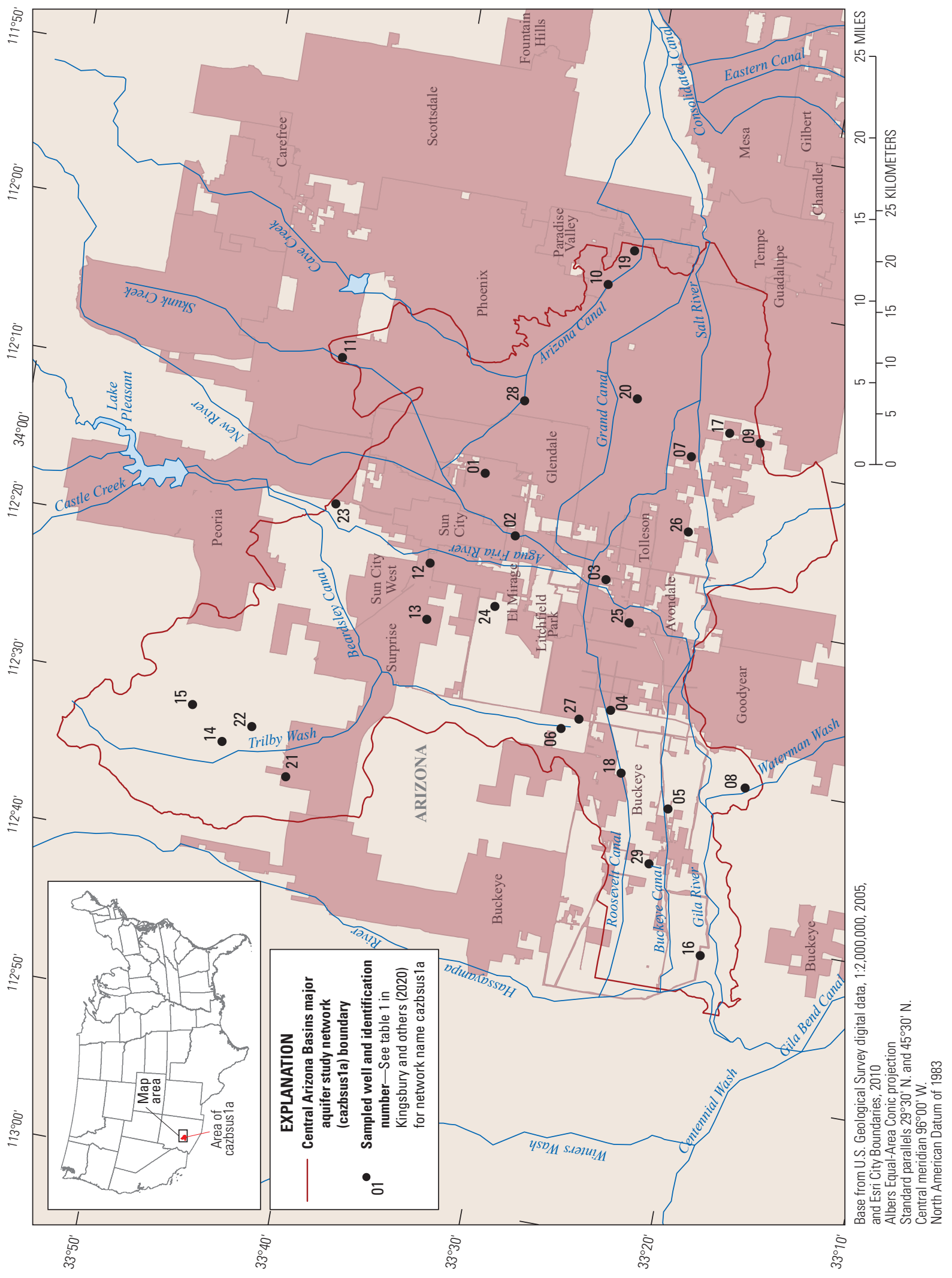

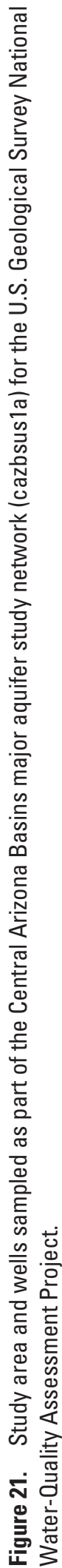




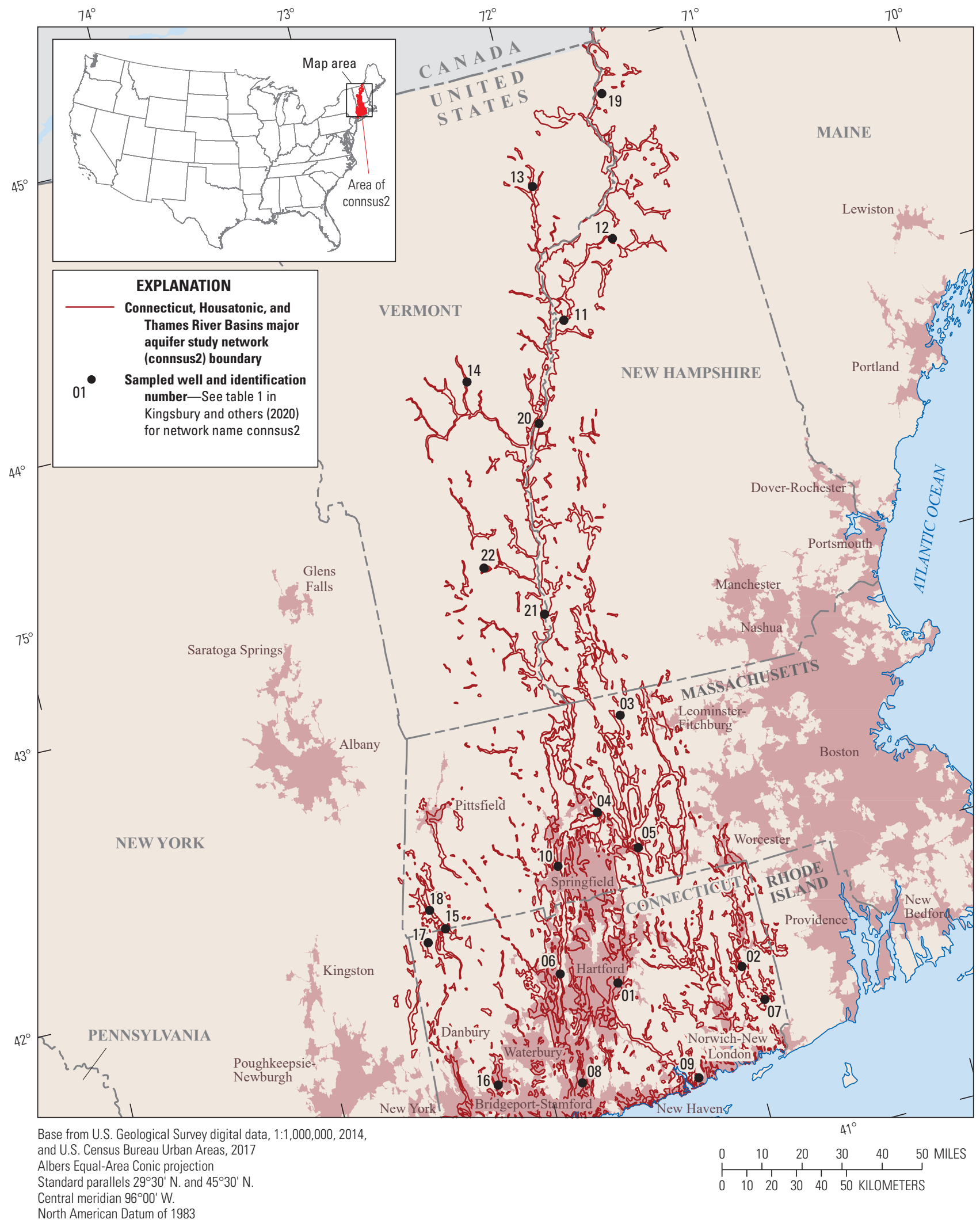

Figure 22. Study area and wells sampled as part of the Connecticut, Housatonic, and Thames River Basins major aquifer study network (connsus2) for the U.S. Geological Survey National Water-Quality Assessment Project. 


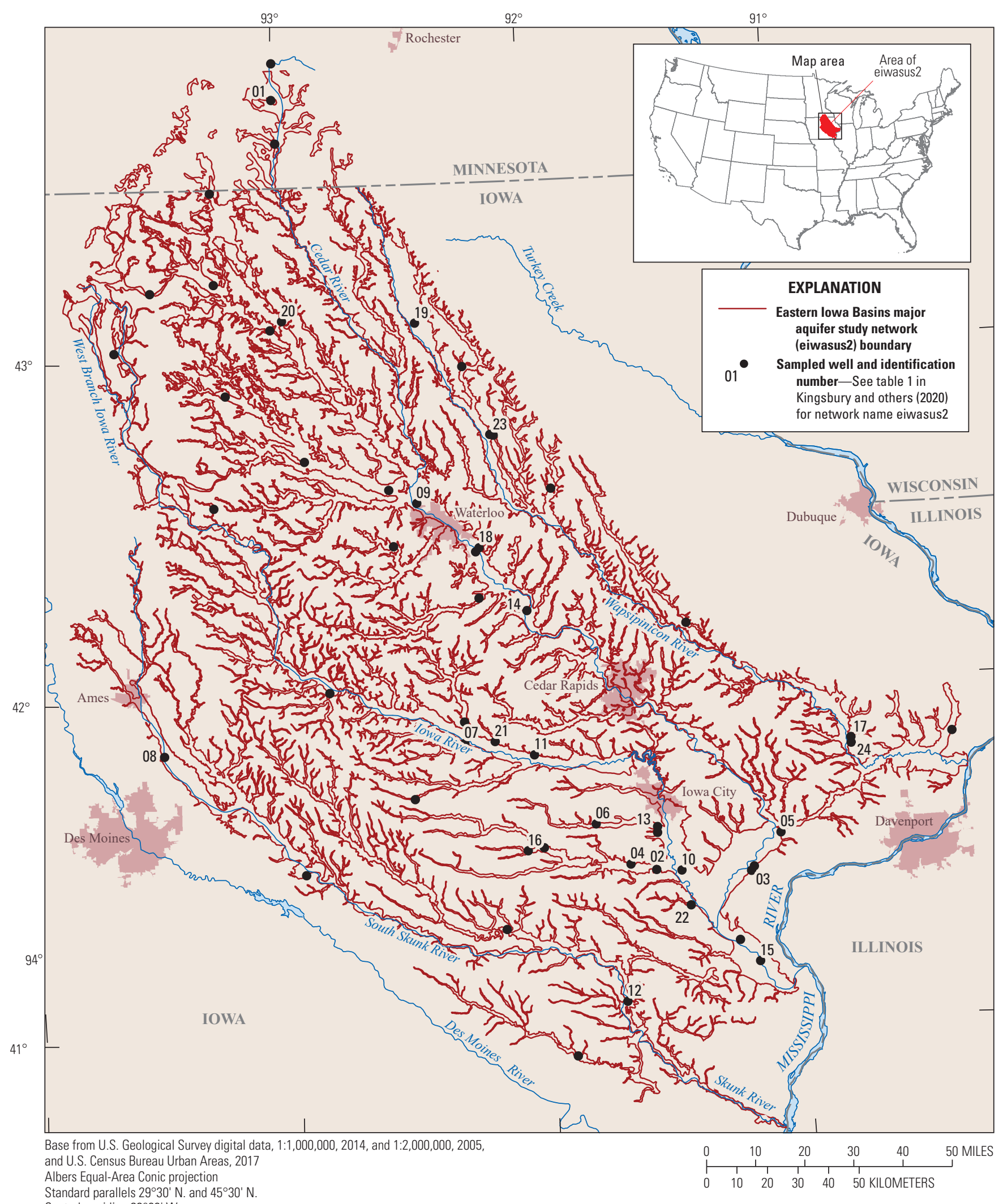

Standard parallels $29^{\circ} 30^{\prime} \mathrm{N}$. and $45^{\circ} 30^{\prime} \mathrm{N}$.

Central meridian $96^{\circ} 00^{\prime} \mathrm{W}$.

Figure 23. Study area and wells sampled as part of the Eastern lowa Basins major aquifer study network (eiwasus2) for the U.S. Geological Survey National Water-Quality Assessment Project. 


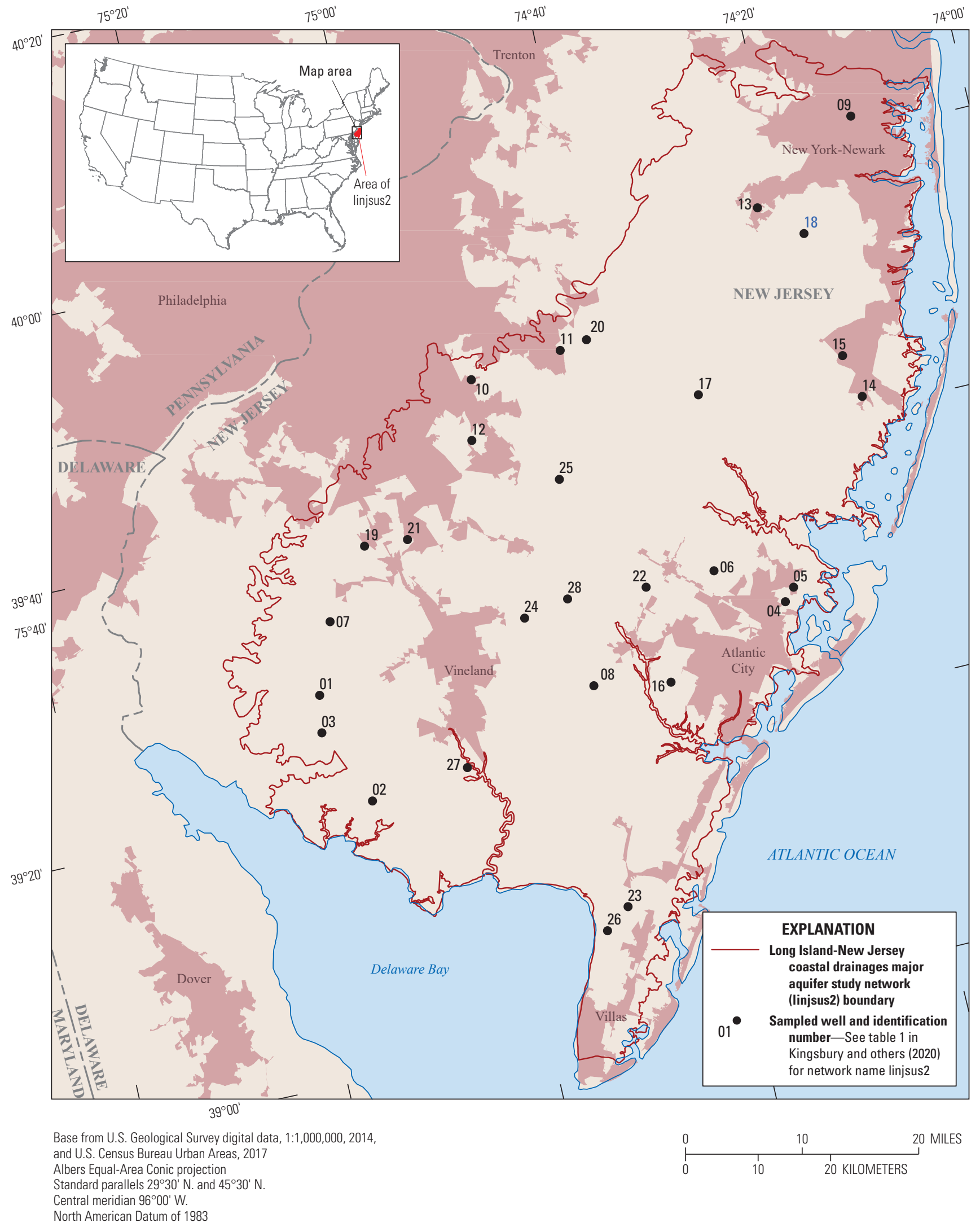

Figure 24. Study area and wells sampled as part of the Long Island-New Jersey coastal drainages major aquifer study network (linjsus2) for the U.S. Geological Survey National Water-Quality Assessment Project. 


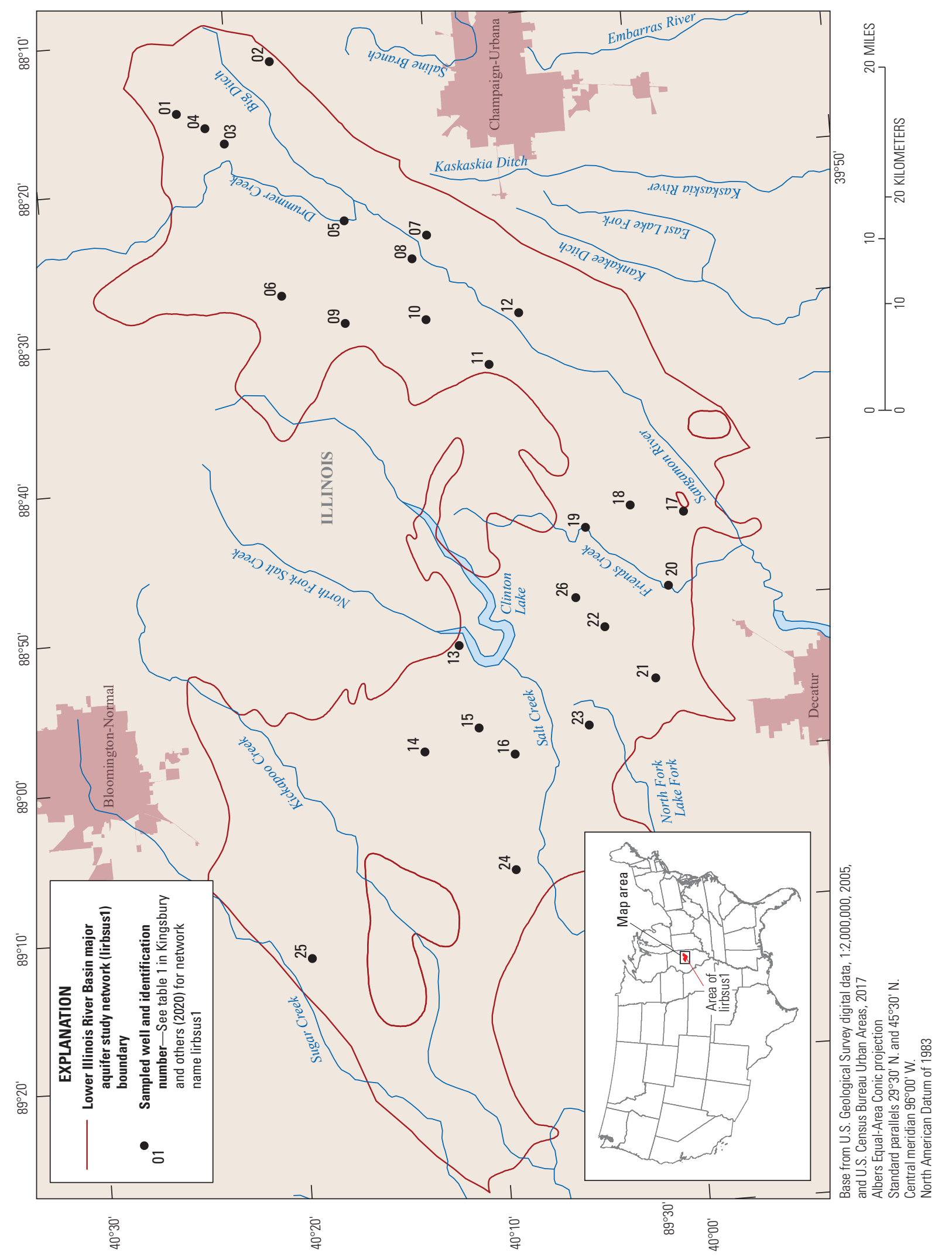

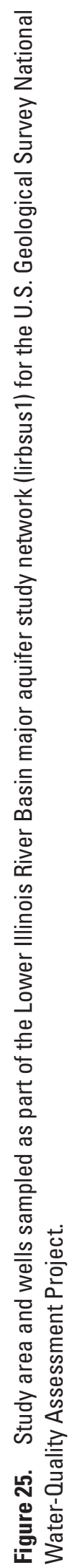




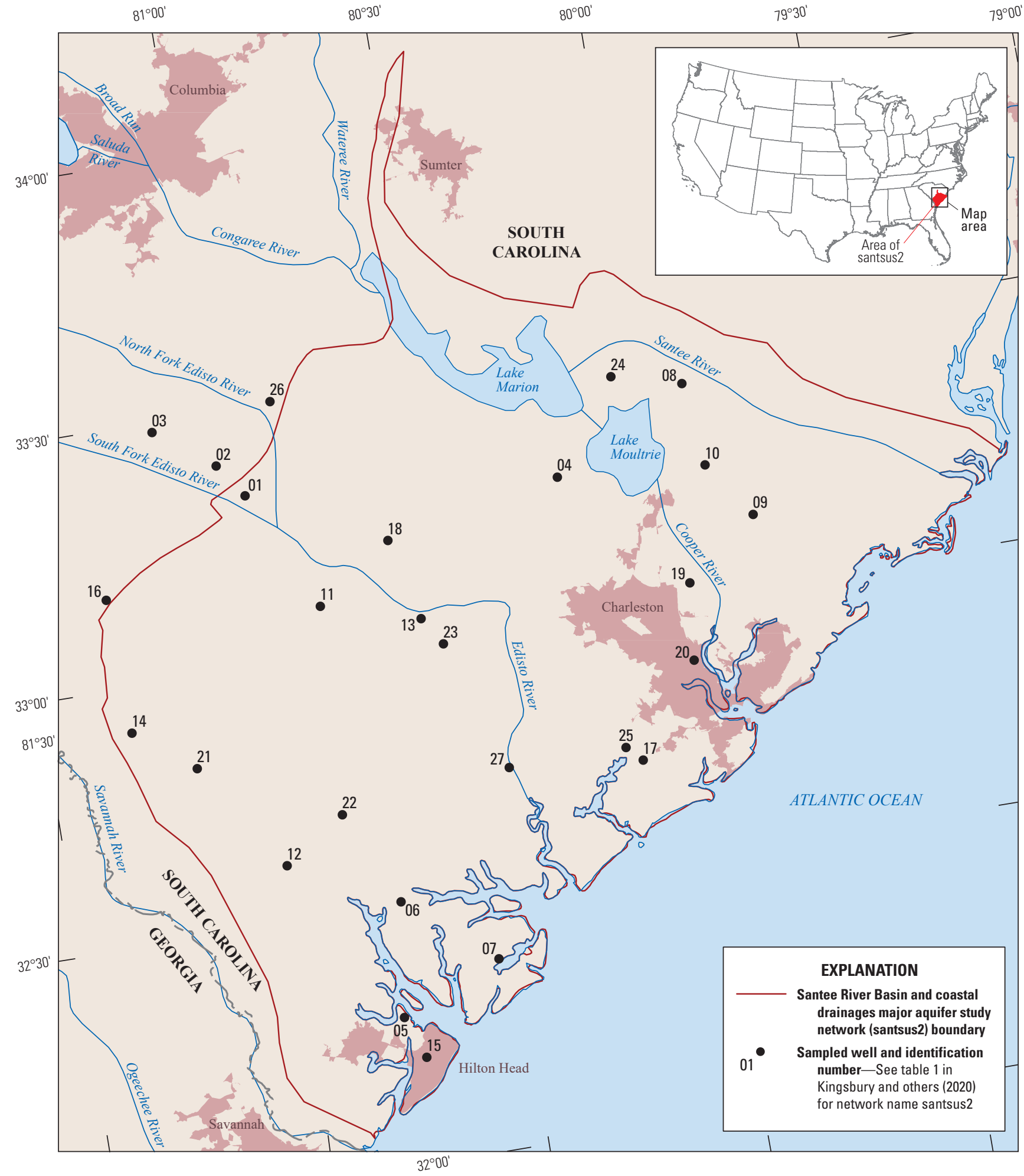

Base from U.S. Geological Survey digital data, 1:1,000,000, 2014, and 1:10,000,000, 2014 U.S. Census Bureau Urban Areas, 2017 Albers Equal-Area Conic projection

Standard parallels $29^{\circ} 30^{\prime} \mathrm{N}$. and $45^{\circ} 30^{\prime} \mathrm{N}$.

Central meridian $96^{\circ} 00^{\prime} \mathrm{W}$.

North American Datum of 1983

Figure 26. Study area and wells sampled as part of the Santee River Basin and coastal drainages major aquifer study network (santsus2) for the U.S. Geological Survey National Water-Quality Assessment Project. 


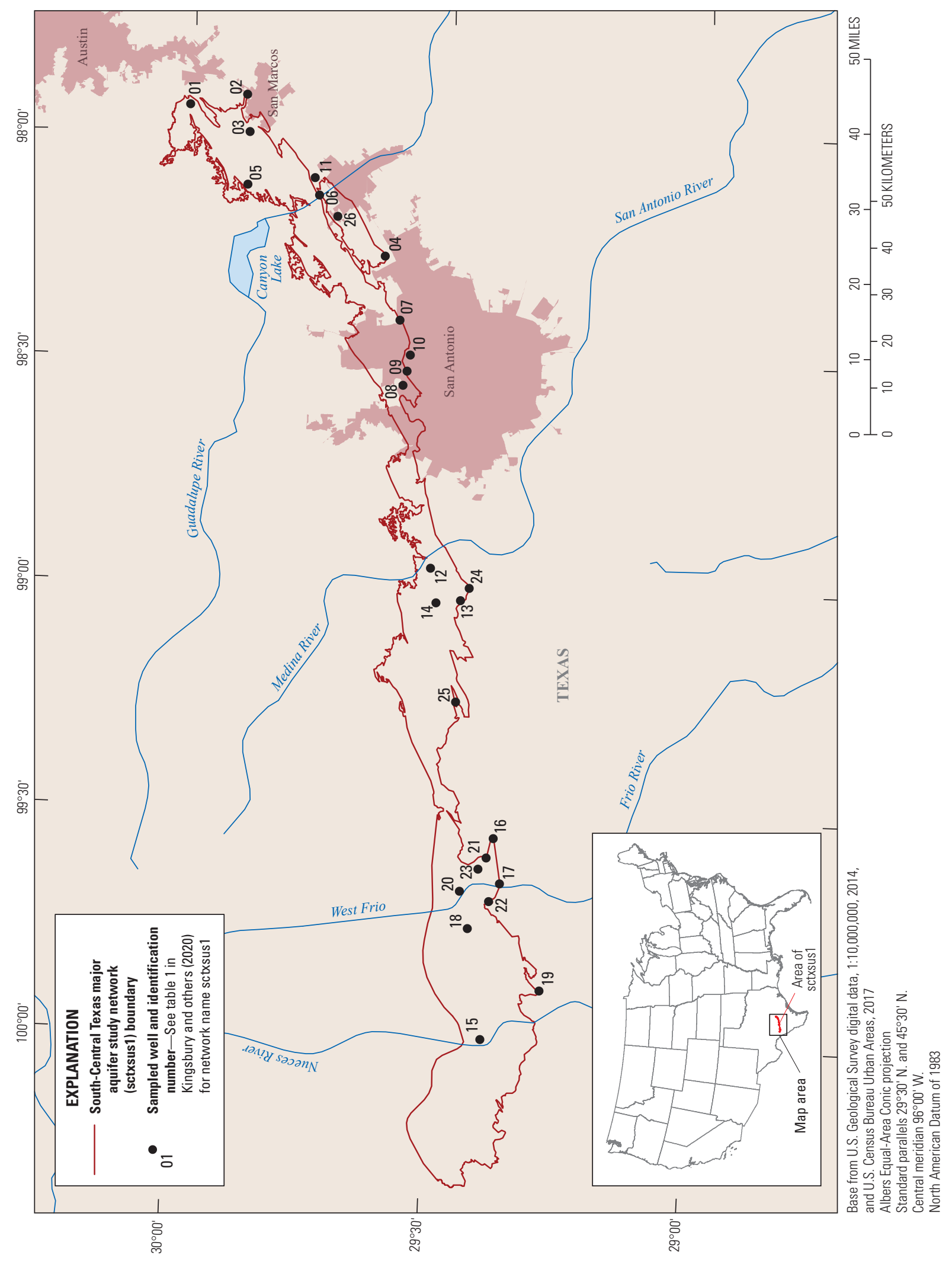

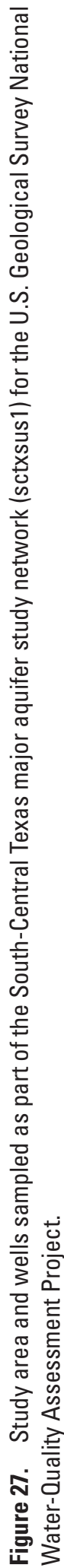




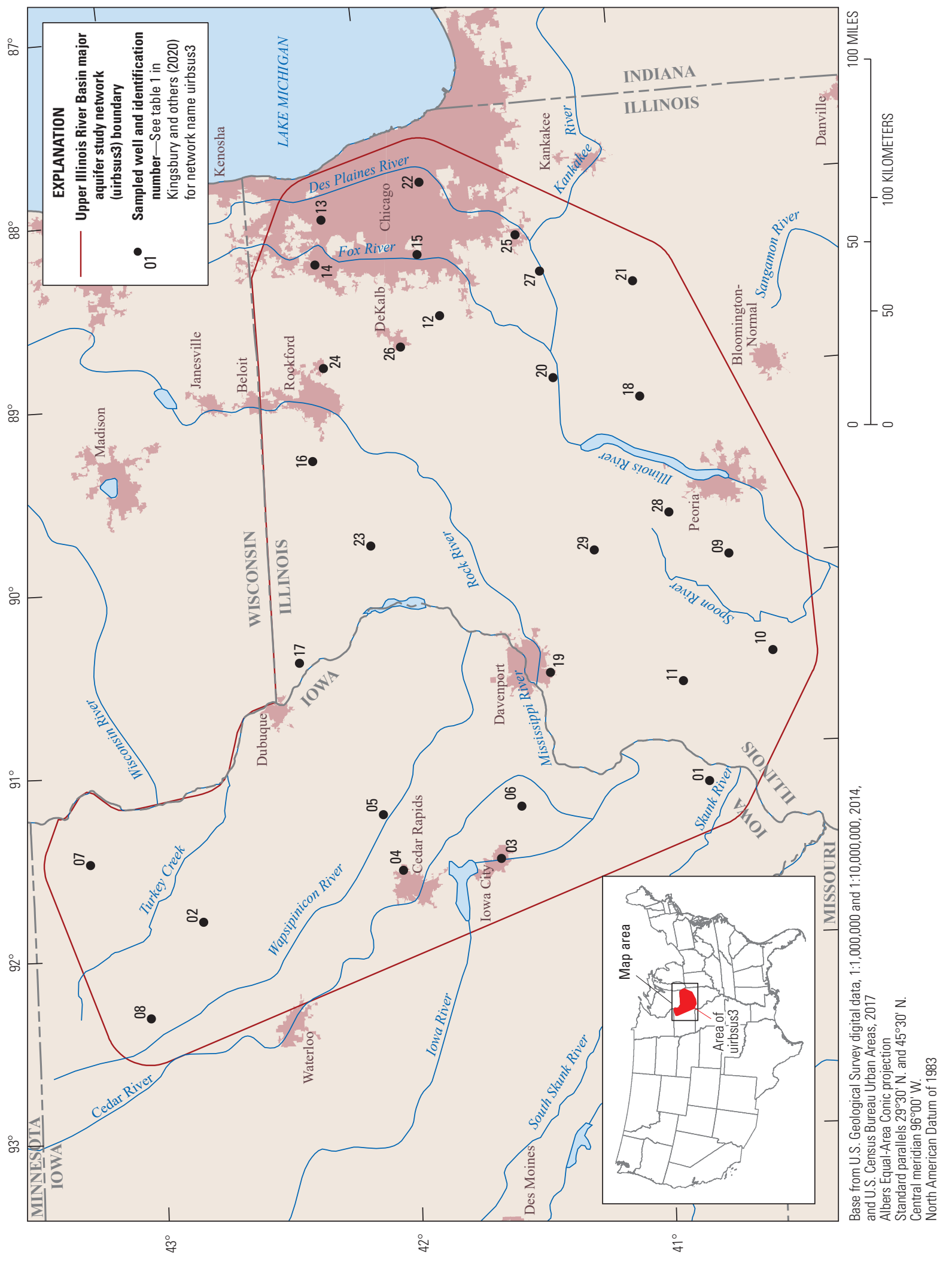

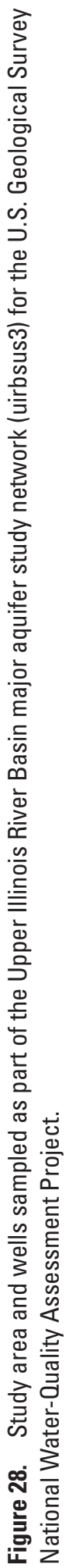




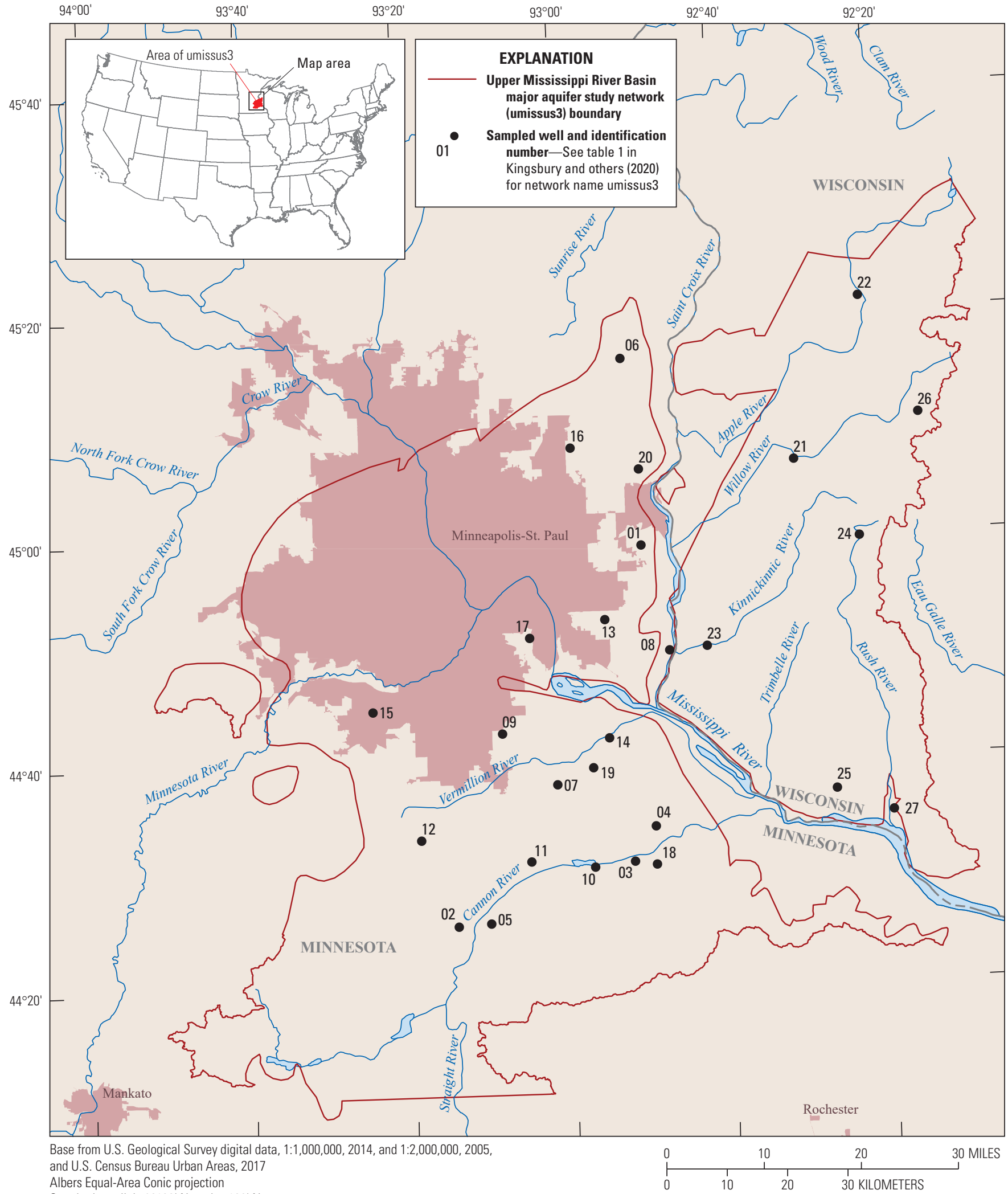

Albers Equal-Area Conic projection

Standard parallels $29^{\circ} 30^{\prime} \mathrm{N}$. and $45^{\circ} 30^{\prime} \mathrm{N}$.

Central meridian $96^{\circ} 00^{\prime} \mathrm{W}$.

North American Datum of 1983

Figure 29. Study area and wells sampled as part of the Upper Mississippi River Basin major aquifer study network (umissus3) for the U.S. Geological Survey National Water-Quality Assessment Project. 
was the fastest growing city in the United States during the 1990s, and remains so currently, with concentrated population growth that relies on surface water and groundwater for water supply (Cordy and others, 2000; U.S. Census Bureau, 2019). The Basin and Range lowlands consist of deep, broad alluvial basins separated by mountain ranges. The basins are filled with thick deposits of gravel, sand, silt, and clay and, in places, include interbedded evaporites and volcanic rocks (Anderson and others, 1992). Agriculture and urban development have altered sources of recharge and discharge to the basin-fill aquifer in the West Salt River Valley, with resulting groundwater-level declines in some areas (Edmonds and Gellenbeck, 2002).

The cazbsus1a network includes 29 wells, mostly used for domestic supply. The wells range in depth from 100 to $1,200 \mathrm{ft}$ (median of $520 \mathrm{ft}$ ) with a large range of open intervals from 4 to $763 \mathrm{ft}$ (median of $69 \mathrm{ft}$ ). Wells in the cazbsus1a network were previously sampled in 1997 and 2008 (USGS, 2020a).

\section{Connecticut, Housatonic, and Thames River Basins Major Aquifer Study Network (connsus2)}

The Connecticut, Housatonic, and Thames River Basins MAS network (connsus2; fig. 22) was used to characterize the quality of groundwater in glacial aquifers used for domestic supply. The Pleistocene- to Holocene-age surficial aquifers sampled are composed of unconsolidated glacial and fluvial deposits, which are thickest in buried bedrock valleys. Precambrian to early Mesozoic bedrock underly the glacial aquifer. Typical yields of wells in glacial aquifers are 10 to 400 gallons per minute (Olcott, 1995), and the glacial aquifer supplies groundwater for drinking water and other uses. Land use is primarily undeveloped forest in the northern part of the study area and becomes increasingly urban (residential, commercial, and other developed land uses) to the south. The study area covers about 2,640 $\mathrm{mi}^{2}$.

The connsus 2 consists of 22 domestic-supply wells completed in glacial aquifers at depths ranging from 16 to $273 \mathrm{ft}$, with a median of $110 \mathrm{ft}$ (appendix 2, table 2.1). Open intervals typically are 3 to $7 \mathrm{ft}$ (appendix 2, table 2.2). Samples for the current phase of monitoring were collected April through July 2017, and these data are presented in Kingsbury and others (2020). Wells from the connsus2 network were previously sampled in 2002 (USGS, 2020a).

\section{Eastern lowa Basins Major Aquifer Study Network (eiwasus2)}

The Eastern Iowa Basins MAS network (eiwasus2; fig. 23) was used to characterize the quality of groundwater in alluvial stream-valley aquifers used for domestic water supply primarily in Iowa. The study area includes the Wapsipinicon, Cedar, Iowa, and Skunk River Basins, tributaries to the Mississippi River. Surficial alluvial deposits are present in
Holocene-age river valleys and commonly consist of 30 to $100 \mathrm{ft}$ of unconsolidated sands and gravels interbedded with silts and clays (Steinhilber and Horick, 1970; Wahl and others, 1978; Olcott, 1992). The surficial permeable sands and gravels, the shallow depth to the water table, and the absence of confining units make these alluvial aquifers susceptible to contamination from land-use activities. Surficial alluvial aquifers and Quaternary-age buried-channel and glacial-outwash deposits supply a substantial part of groundwater used in the study area, including drinking-water supply. Row-crop agriculture is the dominant land use in the study unit (Savoca and others, 2000). The study area covers about $4,300 \mathrm{mi}^{2}$.

The eiwasus 2 consists of 24 domestic-supply wells with depths from 14 to $196 \mathrm{ft}$, with a median of $72 \mathrm{ft}$ (appendix 2, table 2.1). Open intervals ranged from 4 to $20 \mathrm{ft}$ (appendix 2, table 2.2). Samples for the current phase of monitoring were collected May through October 2017, and these data are presented in Kingsbury and others (2020). Wells from the eiwasus2 network were previously sampled in 1998 and 2007 (USGS, 2020a).

\section{Long Island-New Jersey Coastal Drainages Major Aquifer Study Network (linjsus2)}

The Long Island-New Jersey coastal drainages MAS network (linjsus2; fig. 24) was designed to assess the water quality in the unconfined surficial Kirkwood-Cohansey aquifer system. The linjsus 2 study area covers about $2,600 \mathrm{mi}^{2}$ in New Jersey and includes the linjlusrc1 LUS network described previously. The Kirkwood-Cohansey aquifer consists of unconsolidated gravel, sand, silt, and clay of Miocene age. These sediments thicken toward the coast to as much as $300 \mathrm{ft}$ thick (Pope and others, 2012).

The linjsus 2 consists of 28 domestic-supply wells that range in depth from 38 to $175 \mathrm{ft}$, with a median of $100 \mathrm{ft}$ (appendix 2, table 2.1), and open intervals were generally 5-10 ft (appendix 2, table 2.2). Samples for the current phase of monitoring were collected during June and October 2018, and these data are presented in Kingsbury and others (2020). Wells from the linjsus 2 network were previously sampled in 1998 and 2006 (USGS, 2020a).

\section{Lower Illinois River Basin Major Aquifer Study Network (lirbsus1)}

The Lower Illinois River Basin MAS network (lirbsus1; fig. 25) was designed to characterize the water quality within the deep glacial deposits in buried bedrock valleys in the Mahomet Buried Bedrock Valley aquifer system in the Bloomington Ridged Till Plain. The valley deposits are composed primarily of pre-Illinoian-age glacial sediments and are overlain by Wisconsinan glacial deposits at the surface. Confining clays and silts in the Wisconsinan-age, Illinoian, and pre-Illinoian till overlying the deep glacial sediment aquifer are commonly greater than $100 \mathrm{ft}$ thick (Morrow, 2001). 
This aquifer system is the largest source of groundwater for irrigation, industrial, and municipal water supplies in eastcentral Illinois. At least 40 municipalities and water districts withdraw water from these aquifers (Kempton and others, 1991). Most of the area is overlain by agricultural land use, with small areas of forest, urban, and miscellaneous land use. The study area covers about $1,000 \mathrm{mi}^{2}$.

The lirbsus 1 consists of 26 domestic-supply wells completed in glacial aquifers at depths from 200 to $365 \mathrm{ft}$, with a median of $249 \mathrm{ft}$ (appendix 2, table 2.1). Open intervals were generally 4-11 ft (appendix 2, table 2.2). Samples for the current phase of monitoring were collected during May through August 2018, and these data are presented in Kingsbury and others (2020). Wells from the lirbsus 1 network were previously sampled in 1996 and 2007 (USGS, 2020a).

\section{Santee River Basin and Coastal Drainages Major Aquifer Study Network (santsus2)}

The Santee River Basin and coastal drainages aquifer system has a spatial extent of $24,000 \mathrm{mi}^{2}$, where about 3.5 million people live in North and South Carolina (Hughes and others, 2000). Most of the groundwater in the Santee River Basin and coastal drainages aquifer system is withdrawn from three aquifers: (1) the Piedmont aquifer, (2) the Sand Hills aquifer, and (3) the Floridan aquifer. Groundwater in the Piedmont aquifer occurs in fractures in the crystalline rocks, and the Sand Hills aquifer is an unconfined surficial aquifer. The Floridan aquifer system consists of Tertiary-aged carbonate rock sequences, which thicken and become more confined toward the coast like the Northern Atlantic Coastal Plain aquifers (Miller, 1986). Depending on location, the Floridan aquifer system can be under confined, semiconfined, or unconfined conditions. Recharge to the Upper Floridan aquifer primarily is in outcrop areas, and the general direction of groundwater flow is in all directions from the inland outcrop areas toward the coasts (Miller, 1986). Land use in the study consists primarily of agriculture, undeveloped forests, and urban areas (Arnold and others, 2018a).

The Santee River Basin and coastal drainages MAS network (santsus2; fig. 26) includes an area of about 7,300 $\mathrm{mi}^{2}$ and consists of 27 domestic-supply wells in the Floridan aquifer at the downgradient (southeast) end of the Santee River Basin near Charleston, S.C. This network was designed to sample water supplies that are intermediate in depth and used for domestic supply or monitoring. Wells were completed at depths from 93 to $1,125 \mathrm{ft}$, with a median of $170 \mathrm{ft}$

(appendix 2, table 2.1), and had open intervals between 5 and $421 \mathrm{ft}$ (appendix 2, table 2.2). Samples for the current phase of monitoring were collected during June and November 2018, and these data are presented in Kingsbury and others (2020). Wells from the santsus 2 network were previously sampled in 1998 and 2006 (USGS, 2020a).

\section{South-Central Texas Major Aquifer Study Network (sctxsus1)}

The South-Central Texas MAS network (sctxsus1; fig. 27) was established to assess the water quality primarily in the unconfined part of the San Antonio segment of the Edwards aquifer. The sctxsus 1 study area covers about $1,090 \mathrm{mi}^{2}$ and includes the area associated with the sctxlusrc1 network (described previously). The Edwards aquifer, a karst aquifer, is one of the most productive aquifers in the Nation (Sharp and Banner, 1997) and is the primary water supply for the city of San Antonio.

The sctxsus 1 consists of 26 primarily domestic and public-supply wells. The wells range from 80 to $600 \mathrm{ft}$ deep (appendix 2, table 2.1), with a median depth of about $360 \mathrm{ft}$. Open intervals range from 1 to about $460 \mathrm{ft}$ (appendix 2, table 2.2). Samples for the current phase of monitoring were collected from March through June 2018, and these data are reported here. Wells from the sctxsus 1 network were previously sampled in 1996 and 2006 (USGS, 2020a).

\section{Upper Illinois River Basin Major Aquifer Study Network (uirbsus3)}

The Upper Illinois River Basin MAS network (uirbsus3; fig. 28) was designed to characterize water quality in the Cambrian-Ordovician aquifer, which is an important source of water for domestic and public supply in Illinois. The Cambrian-Ordovician aquifer is overlain by Quaternary-age unconsolidated aquifers and Silurian-Devonian-age bedrock aquifers (Friedel, 1998). Regional groundwater flow is generally from west to east; intermediate and local flow is spatially variable throughout the study area (Friedel, 1998). The Cambrian-Ordovician aquifer consists of numerous alternating layers of sandstone, limestone, and dolomite. On a regional scale, the layers of Cambrian and Ordovician strata are hydraulically interconnected and act as a single aquifer (Visocky and others, 1985). Land use in the study area consists primarily of agriculture, undeveloped forests, and urban areas. The study area covers about $31,000 \mathrm{mi}^{2}$.

The uirbsus 3 consists of 29 public-supply wells completed in the bedrock aquifer at depths from about 570 to $2,500 \mathrm{ft}$, with a median of $1,500 \mathrm{ft}$ (appendix 2, table 2.1). Open intervals were 206-1,494 ft (appendix 2, table 2.2). Samples for the current phase of monitoring were collected during May through August 2017, and these data are presented in Kingsbury and others (2020). Wells from the uirbsus3 network were previously sampled in 2007 (USGS, 2020a).

\section{Upper Mississippi River Basin Major Aquifer Study Network (umissus3)}

The Upper Mississippi River Basin MAS network (umissus3; fig. 29) was designed to characterize water quality in the Prairie du Chien-Jordan aquifer, which is the primary source 
of groundwater for domestic wells and public water supplies in the Minneapolis/St. Paul Twin Cities metropolitan area (Fong and others, 1998). The study unit area has 50 to $450 \mathrm{ft}$ of glacial and alluvial deposits overlying as much as $1,000 \mathrm{ft}$ of Precambrian- to Devonian-age sedimentary strata (Bloomgren and others, 1989; Meyer and Hobbs, 1989). Under the Twin Cities metropolitan area, these sedimentary bedrock units fill a concave depression known as the Twin Cities Basin. The Prairie du Chien-Jordan aquifer consists of as much as $335 \mathrm{ft}$ of fractured sandy dolomite of the Ordovician-age Prairie du Chien Group and the underlying quartz sandstone of the Cambrian-age Jordan Sandstone. The aquifer in the Prairie du Chien Group and the Jordan Sandstone are hydraulically connected and have traditionally been considered a single aquifer (Delin and Woodward, 1984; Young, 1992a, b). The Prairie du Chien-Jordan aquifer is the principal source of water for public-supply wells in suburban areas of the Twin Cities metropolitan area and also is the primary source of water for domestic wells inside and outside of the Twin Cities metropolitan area in the study area. Land use in the study consists primarily of agriculture, undeveloped forests, and urban areas. The study area covers about $4,100 \mathrm{mi}^{2}$.

The umissus 3 consists of 27 domestic-supply wells completed in the Prairie du Chien-Jordan aquifer at depths from 66 to $380 \mathrm{ft}$, with a median of $180 \mathrm{ft}$ (appendix 2, table 2.1). Open intervals ranged from 1 to $190 \mathrm{ft}$ (appendix 2, table 2.2). Samples for the current phase of monitoring were collected during July and August 2018, and these data are presented in Kingsbury and others (2020). Wells from the umissus3 network were previously sampled in 1996 and 2007 (USGS, 2020a).

\section{Enhanced Trends Networks}

An ETN consists of a small number of wells (typically two to four) that are sampled to evaluate the time scales during which groundwater quality changes. Such changes might result from seasonal or annual variability in recharge, discharge, or contaminant loading (Rowe and others, 2013). These networks are within decadal trend networks and are designed to collect high-frequency data that can be used to better understand the factors that cause variability in groundwater quality and to aid in interpreting long-term trends for the decadal networks. Data from eight ETNs are included in this report (figs. 30 and 31): Central Valley ETN (cvaletn1), Columbia Plateau ETN (clptetn1), EdwardsTrinity aquifer system ETN (edtretn1), glacial aquifer system ETN (glacetn1), Mississippi Embayment aquifer system ETN (metxetn1), Northern Atlantic Coastal Plain ETN (nacpetn1), New England crystalline-rock and glacial aquifer system ETN (negxetn1), and the Rio Grande aquifer system ETN (rgaqetn1).
Wells in an ETN are instrumented for high-frequency measurement of selected parameters, and they periodically have discrete measurements of additional parameters (USGS, 2020c). The parameters measured at a high frequency differ among wells and networks but generally include parameters like temperature, dissolved oxygen, $\mathrm{pH}$, and specific conductance. Data collected at a high frequency for wells in the ETNs are available online; links to the data are provided in appendix 4, table 4.1 .

For periodic discrete sampling, the ETNs are divided into two groups of four networks that are sampled on a 4-year alternating cycle. Four networks are sampled about once every 2 months for 4 years, whereas the other four networks are sampled annually. After the first 4-year period, the sampling frequency switches; the networks that were sampled every 2 months during the first period are sampled annually, and the other four networks are sampled every 2 months. Water-quality data from the discrete sampling during 2017-19 are included in Kingsbury and others (2020).

\section{Columbia Plateau Enhanced Trends Network (clptetn1)}

The Columbia Plateau ETN (clptetn1; fig. 30A, B) in the Columbia Plateau aquifer system was designed to investigate questions about how groundwater quality differs between the shallow basin-fill (unconsolidated deposits) aquifers and the deeper, underlying basaltic-rock aquifers and how water quality varies along the flow paths. The environmental setting of clptetn 1 previously was described in Arnold and others $(2017 \mathrm{a}, \mathrm{b})$ and is not repeated in this report.

The clptetn 1 is made up of wells that represent different positions within the regional groundwater-flow system at different depths. Well CLPTETN1-01 is a shallow (80 ft), domestic well in the sand and gravel aquifer. Well CLPTETN1-04 is a deep $(1,116 \mathrm{ft})$, long-screened (926-1,100 ft) supply well that is open to the basaltic-rock aquifers; this well is about 20 mi south of the Columbia River and is the most proximal of the three wells. Well CLPTETN1-05 is a shallow to moderate depth (170 ft) industrial well, cased to $144 \mathrm{ft}$ also in the sand and gravel aquifer.

Wells CLPTETN1-02 and CLPTETN1-03 were sampled as part of the clptetn1 in 2014 (Arnold and others, 2017a, b); however, because of issues with sample quality and sampling access, these wells are no longer included in the clptetn1. Well CLPTETN1-01 also was sampled in 2014 (Arnold and others, 2017a, b). Wells CLPTETN1-01, CLPTETN1-04, and CLPTETN1-06 were sampled in 2015, and the data were reported in Arnold and others (2018a, b). Well CLPTETN1-06 was not resampled in 2016 because access to the well was denied; well CLPTETN1-05 was sampled instead. Wells CLPTETN1-01, CLPTETN1-04, and CLPTETN1-05 were sampled in 2017 through 2019, and the data are in Kingsbury and others (2020). 


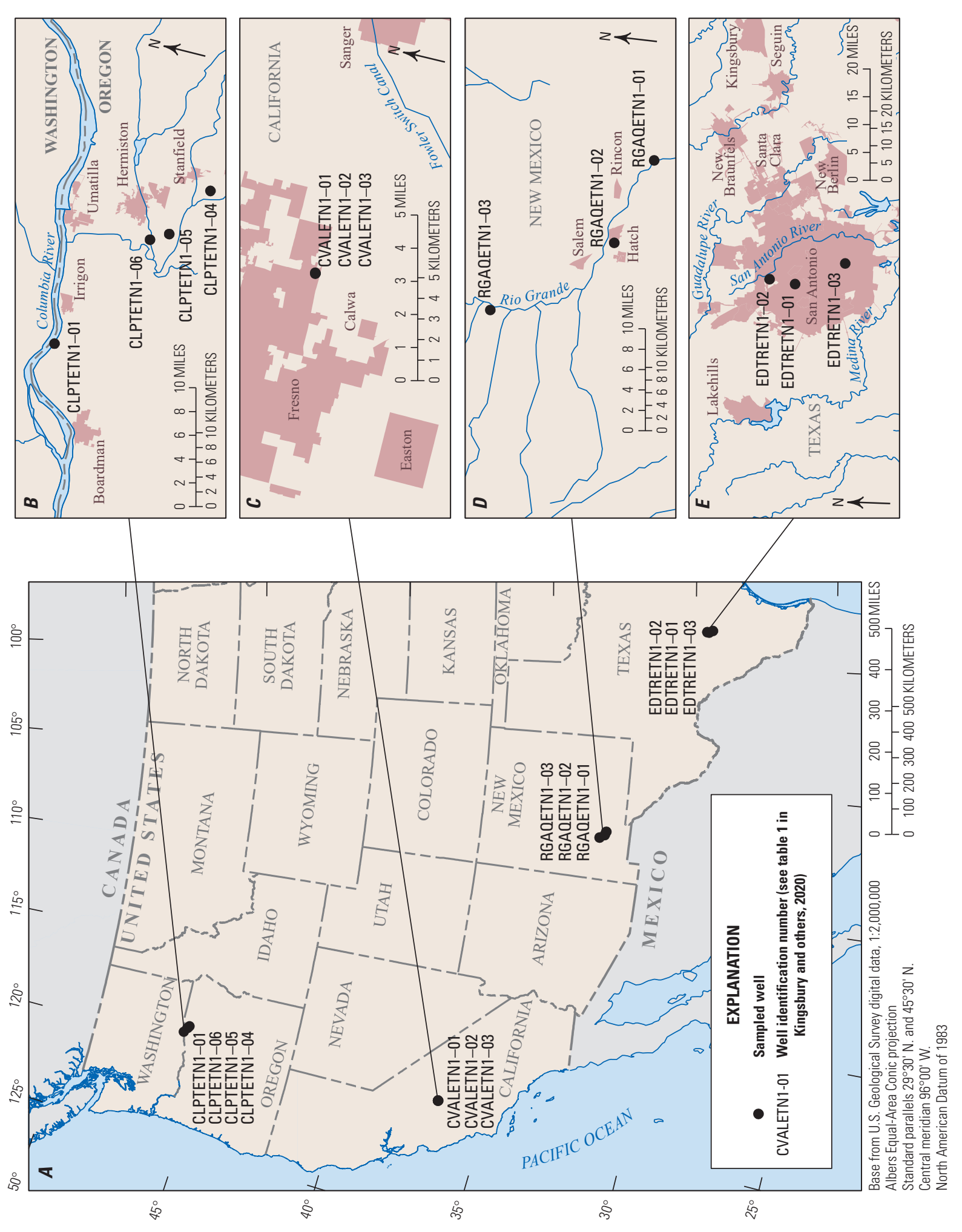

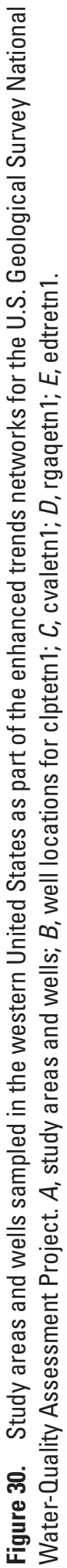




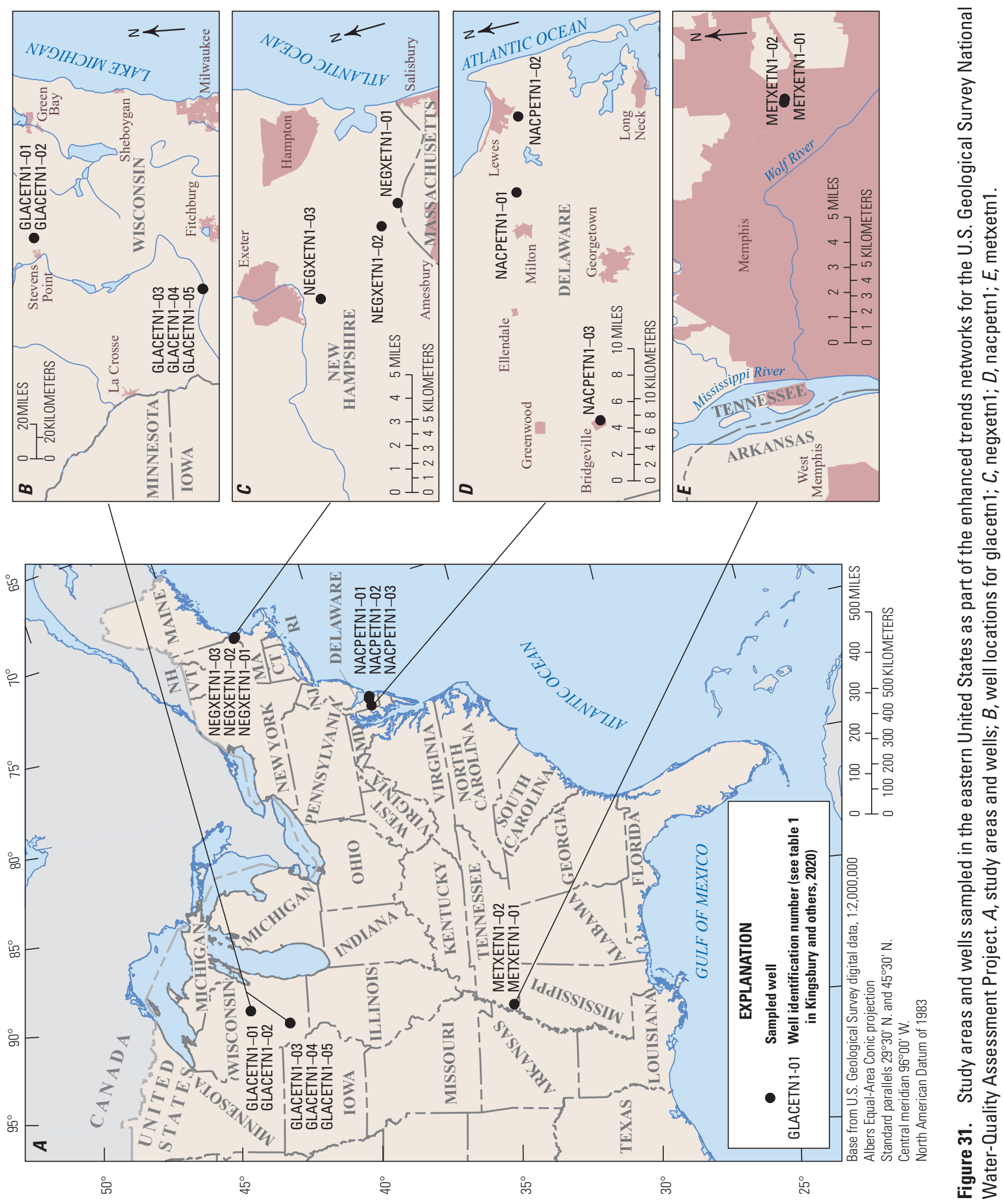




\section{Central Valley Enhanced Trends Network (cvaletn1)}

The Central Valley ETN (cvaletn1; fig. 30A, C) in the Central Valley aquifer system is intended to aid in the understanding of the subsurface movement of groundwater constituents (in some cases, contaminants from land-use practices) between the shallow and deep parts of the aquifer system. The environmental setting of cvaletn 1 previously was described in Arnold and others $(2017 \mathrm{a}, \mathrm{b})$ and is not repeated in this report.

The cvaletn 1 is made up of three wells that represent different depths in the regional aquifer. Two wells are relatively shallow (CVALETN1-02, $320 \mathrm{ft}$ deep; CVALETN1-03, $234 \mathrm{ft}$ deep), and one well is relatively deep (CVALETN1-01, $620 \mathrm{ft}$ deep). All three wells in the cvaletn 1 were sampled previously in 2013 (Arnold and others, 2016a, b), 2014 (Arnold and others, 2017a, b), 2015 (Arnold and others, 2018a, b), and 2016 (Arnold and others, 2020a, b). Data from samples collected from 2017 to 2019 are included in Kingsbury and others (2020).

\section{Rio Grande Aquifer System Enhanced Trends Network (rgaqetn1)}

The Rio Grande aquifer system ETN (rgaqetn1; fig. $30 A, D$ ) provides the opportunity to study temporal variability in the water quality of shallow groundwater affected by irrigation, river water infiltration, and variable hydrologic conditions in an arid climate. The environmental setting of rgaqetn 1 previously was described in Arnold and others $(2017 \mathrm{a}, \mathrm{b})$ and is not repeated in this report.

The rgaqetn 1 consists of three wells completed in the valley fill at different depths: two shallow wells that are screened across the water table (RGAQETN1-01, $23 \mathrm{ft}$ deep; RGAQETN1-03, $22 \mathrm{ft}$ deep) and one deeper well (RGAQETN1-02, $60 \mathrm{ft}$ deep). The wells were sampled as part of the rgaqetn 1 in 2014 (Arnold and others, 2017a, b), 2015 (Arnold and others, 2018a, b), and again in 2016 (Arnold and others, $2020 \mathrm{a}, \mathrm{b})$. Two samples were collected at these wells in 2017 (May and November), and the wells were sampled about every other month between January 2018 and May 2019. Results for 2017 to 2019 are included in Kingsbury and others (2020).

\section{Edwards-Trinity Aquifer System Enhanced Trends Network (edtretn1)}

The Edwards-Trinity aquifer system ETN (edtretn1; fig. $30 \mathrm{~A}, \mathrm{E}$ ) was designed to evaluate temporal variability in groundwater quality in a dynamic karst aquifer. The environmental setting of edtretn 1 previously was described in Arnold and others $(2017 \mathrm{a}, \mathrm{b})$ and is not repeated in this report.

There are three wells in the edtretn 1 that are along an approximately north-to-south aquifer transect within the San Antonio metropolitan area (fig. 30E). One well is in the upgradient, unconfined recharge zone, and two wells are downgradient in the confined zone. The upgradient well (EDTRETN1-02) is $300 \mathrm{ft}$ deep and open to the aquifer along the bottom $80 \mathrm{ft}$ of its depth. The downgradient wells are $550 \mathrm{ft}$ (EDTRETN1-01) and 1,550 ft (EDTRETN1-03) deep and are open to the aquifer throughout their length below the confined zone. The farthest downgradient well (EDTRETN1-03) is close to the southern boundary of the aquifer. Wells in the edtretn 1 were first sampled as part of the edtretn 1 in 2013 (Arnold and others, 2016a, b) and were sampled again in 2014 (Arnold and others, 2017a, b), 2015 (Arnold and others, 2018a, b), and 2016 (Arnold and others 2020a, b). During 2017, the wells were sampled approximately bimonthly from January through October 2017. These wells were sampled one time in 2018 and 2019, and these data are included in Kingsbury and others (2020). In 2017 , these wells were sampled as part of the edtrpas 1 network (EDTRETN1-01, EDTRETN1-03) and the sctxlusrc1 (EDTRETN1-02).

\section{Glacial Aquifer System Enhanced Trends Network (glacetn1)}

The glacial aquifer system ETN (glacetn1; fig. 31A, B) was designed to identify the temporal variability and magnitude of observed changes in groundwater quality in agricultural areas of the glacial aquifer system. The environmental setting of glacetn1 previously was described in Arnold and others $(2017 \mathrm{a}, \mathrm{b})$ and is not repeated in this report.

The glacetn 1 consists of five wells distributed in two locations. A location in central Wisconsin has two monitoring wells: GLACETN1-01 (83 ft deep) and GLACETN1-02 (34.5 ft deep). A location in southwestern Wisconsin has three wells: monitoring wells GLACETN1-03 (50 ft deep) and GLACETN1-04 (89 ft deep) and public-supply well GLACETN1-05 (125 ft deep). All wells in the glacetn1 were sampled in 2016, and these data are included in Kingsbury and others (2020). Wells GLACETN1-01 and GLACETN1-02 have been sampled every year since 2014 and GLACETN1-03, GLACETN1-04, and GLACETN1-05 every year since 2015 (Arnold and others, 2017a, b, 2018a, b, 2020b). Between August 2017 and May 2019, bimonthly samples were collected at these wells, except for GLACETN1-04. Results for the four wells sampled are included in Kingsbury and others (2020).

\section{Mississippi Embayment Aquifer System Enhanced Trends Network (metxetn1)}

The Mississippi Embayment aquifer system ETN (metxetn1; fig. 31A, E) was designed to study how water quality in shallow and deep parts of the regional aquifer changes in response to changing hydrologic conditions and pumping. The environmental setting of metxetn 1 previously was described in Arnold and others (2017a, b) and is not repeated in this report. 
The metxetn1 consists of one well in the shallow aquifer (METXETN1-02, $90 \mathrm{ft}$ deep) and one well in the Memphis aquifer (METXETN1-01, $624 \mathrm{ft}$ deep). The wells were first sampled as part of the metxetn1 in 2013 (Arnold and others, 2016a, b) and again in 2014 (Arnold and others, 2017a, b) and 2015 (Arnold and others, 2018a, b). Sampling in 2016 was approximately bimonthly, and these data are included in (Arnold and others, 2020a, b). Four samples were collected at these wells during 2017, and annual samples were collected in 2018 and 2019. The data for these six samples are included in Kingsbury and others (2020).

\section{Northern Atlantic Coastal Plain Enhanced Trends Network (nacpetn1)}

The Northern Atlantic Coastal Plain ETN (nacpetn1; fig. $31 A, D$ ) in the Northern Atlantic Coastal Plain aquifer system provides an opportunity to study the movement of contaminants from the land surface downward into aquifers and the effects of recharge and pumping on the temporal variability of water quality. The environmental setting of nacpetn 1 previously was described in Arnold and others (2017a, b) and is not repeated in this report.

The nacpetn 1 network has three wells that are across southern Delaware in different parts of the flow system at different depths. Well NACPETN1-03 (119 ft deep) is a publicsupply well in southwestern Delaware near the center of the Delmarva Peninsula. Well NACPETN1-02 (139 ft deep) also is a public-supply well, one of several supply wells for a coastal town. Well NACPETN1-01 is a shallow monitoring well ( $22 \mathrm{ft}$ ) that is surrounded locally by agricultural land use. All three wells in the nacpetn1 were sampled once in 2014 (Arnold and others, 2017a, b), once in August 2015 (Arnold and others, 2017a, b), and approximately bimonthly during 2016 (Arnold and others, 2020a, b). Bimonthly samples were collected between August 2017 and May 2019, and those results are included in Kingsbury and others (2020).

\section{New England Crystalline-Rock and Glacial Aquifer System Enhanced Trends Network (negxetn1)}

The New England crystalline-rock and glacial aquifer system ETN (negxetn1; fig. 31A,C) provides the opportunity to study the temporal variability of contaminants in groundwater from geologic sources as well as contaminants from manmade sources with changing inputs. The environmental setting of negxetn 1 previously was described in Arnold and others $(2017 \mathrm{a}, \mathrm{b})$ and is not repeated in this report.

The negxetn 1 consists of three wells at different depths. Two of the wells are public-supply wells, one completed in glacial sediments (NEGXETN1-01, $83 \mathrm{ft}$ deep) and the other one completed in the crystalline-rock aquifer (NEGXETN1-02, $492 \mathrm{ft}$ deep), and are in the southern part of the network area. The third well is a domestic-supply well in the northern part (NEGXETN1-03, $176 \mathrm{ft}$ deep). Wells in the negxetn1 were sampled in 2014 (Arnold and others, 2017a, b) and again in 2015 (Arnold and others, 2018a, b). The wells were sampled bimonthly January through November 2016 (Arnold, and others 2020a, b). During 2017, five samples were collected at these wells between January and September, and annual samples were collected in May of 2018 and 2019. Results for these samples are presented in Kingsbury and others (2020).

\section{Vertical Flow-Path Study Networks}

VFPS networks are designed to evaluate changes in groundwater quality over longer periods of time than the ETN and decadal trends networks (LUS and MAS networks) by sampling wells that are along inferred flow paths. The wells in a VFPS network are selected from public, domestic, or monitoring wells and are located so that there is a representation of wells at different depths within a study area. Evaluating vertical gradients of groundwater age and contaminant concentrations facilitates the understanding of changes in groundwater quality over periods of time greater than 10 years. VFPS networks generally are sampled once. Data from the EdwardsTrinity aquifer system VFPS (edtrvfps1, fig. 32), Floridan and surficial aquifer system VFPS (flsfvfps1, fig. 33), glacial aquifer system VFPS (glacvfps2, fig. 34), and Northern Atlantic Coastal Plain aquifer system VFPS (nacpvfps1, fig. 35) are included in Kingsbury and others (2020).

\section{Edwards-Trinity Aquifer System Vertical Flow-Path Study Network (edtrvfps1)}

The Edwards-Trinity aquifer system VFPS network (edtrvfps1; fig. 32) was designed to add a groundwater age framework to results from networks in the San Antonio segment of the Edwards aquifer described previously in this report in the sections about the sctxsus1 and sctxlusrc1 networks. The edtrvfps 1 network consists of 25 wells near the city of San Antonio. Of the wells, 20 are part of the sctxsus 1 network (described earlier in this report) and range in depth from 80 to $600 \mathrm{ft}$ (median of $425 \mathrm{ft}$ ); the additional 5 wells are public-supply wells completed in the deeper confined part of the aquifer (depths range from 660 to 2,700 ft, with a median of $870 \mathrm{ft}$ ). Samples for the VFPS were collected from March to May 2018, and the data are available in Kingsbury and others (2020).

\section{Floridan and Surficial Aquifer System Vertical Flow-Path Study Network (flsfvfps1)}

The Floridan and surficial aquifer system VFPS network (flsfvfps1; fig. 33) was designed to add an age framework to results from decadal networks in these aquifer systems to help address questions of changes in water quality over 


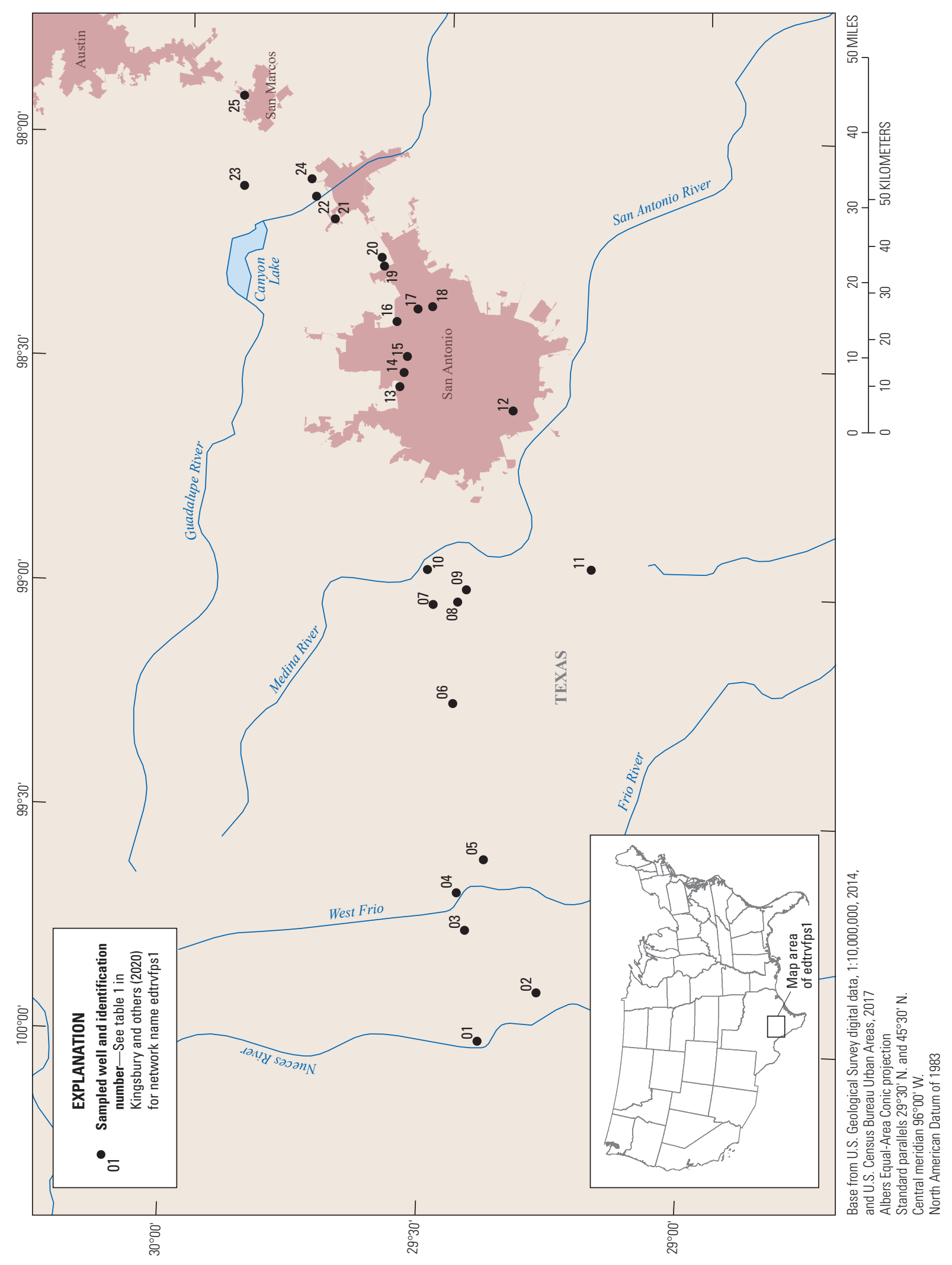

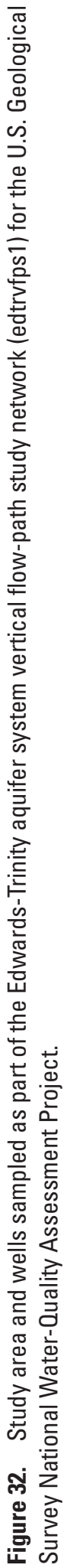




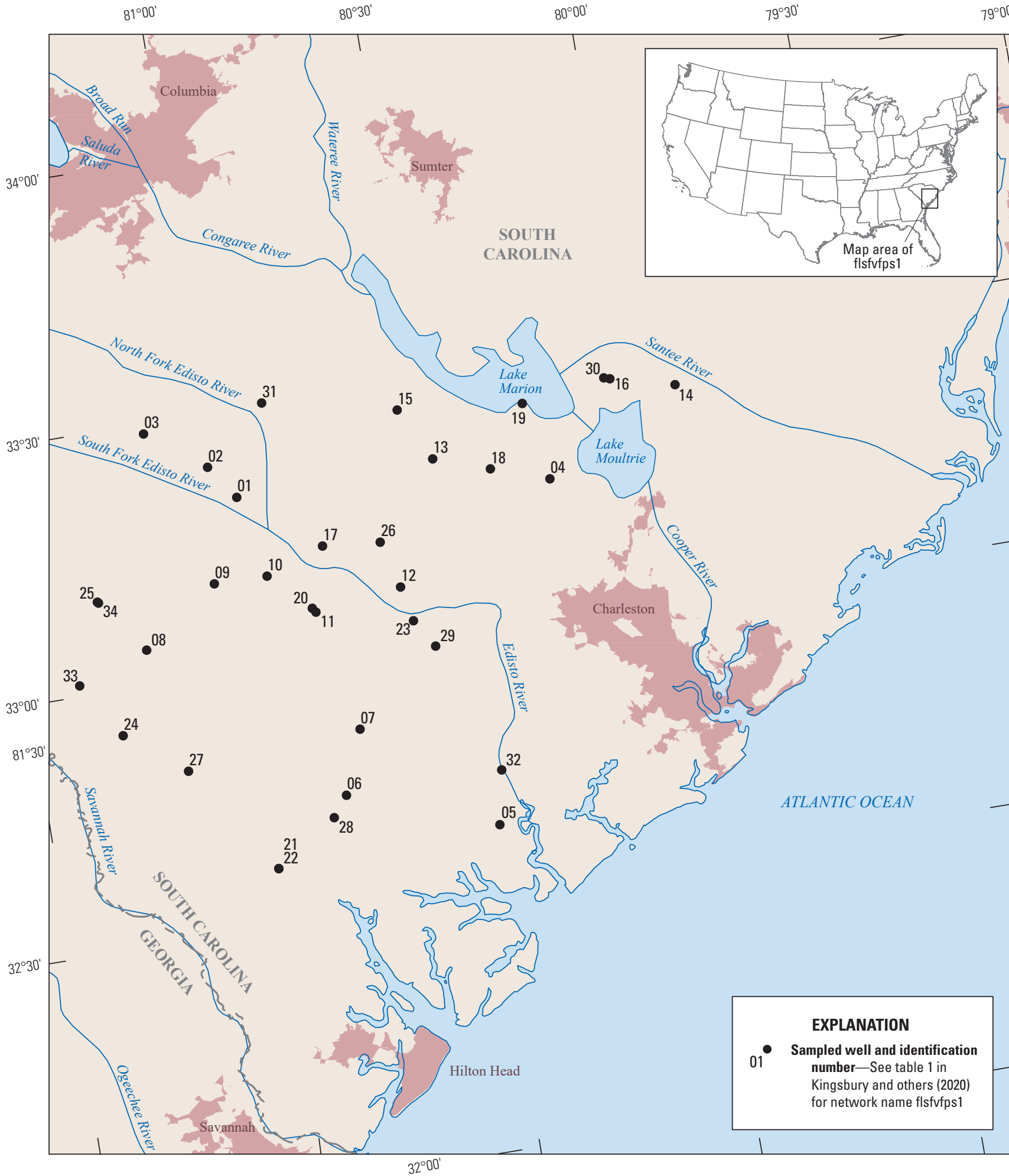

Base from U.S. Geological Survey digital data, 1:1,000,000, 2014, and 1:10,000,000, 2014 U.S. Census Bureau Urban Areas, 2017 Albers Equal-Area Conic projection

Standard parallels $29^{\circ} 30^{\prime} \mathrm{N}$. and $45^{\circ} 30^{\prime} \mathrm{N}$.

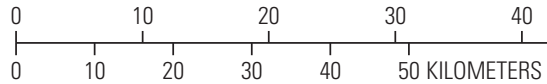
50 MILES

Central meridian $96^{\circ} 00^{\prime} \mathrm{W}$.

North American Datum of 1983

Figure 33. Study area and wells sampled as part of the Floridan and surficial aquifer system vertical flow-path study network (flsfvfps1) for the U.S. Geological Survey National Water-Quality Assessment Project. 


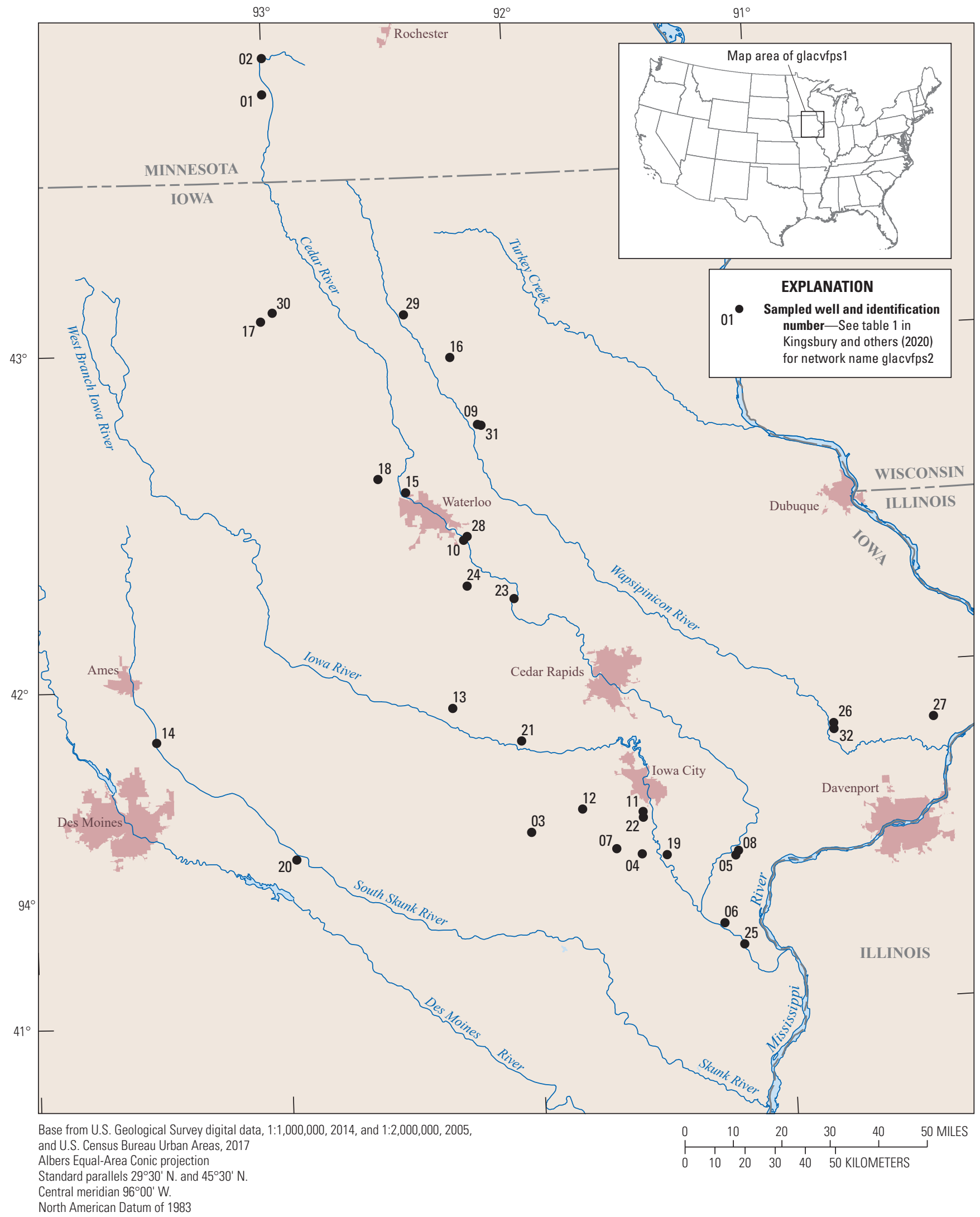

Figure 34. Study area and wells sampled as part of the glacial aquifer system vertical flow-path study network (glacvfps2) for the U.S. Geological Survey National Water-Quality Assessment Project. 


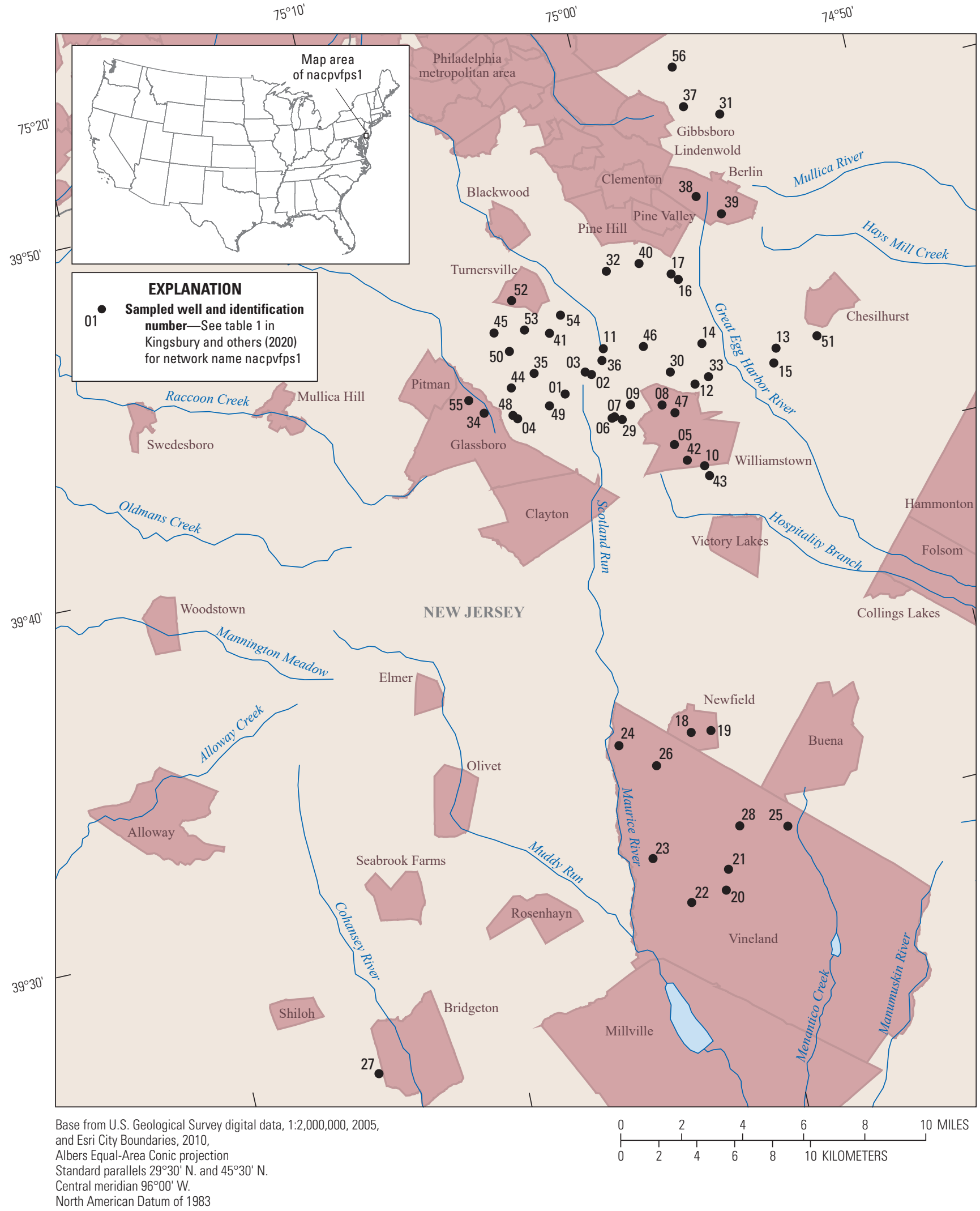

Figure 35. Study area and wells sampled as part of the Northern Atlantic Coastal Plain aquifer system vertical flow-path study network (nacpvfps1) for the U.S. Geological Survey National Water-Quality Assessment Project. 
time. The flsfvfps 1 network is a group of 34 wells that is a combination of wells from the santluscr1 and santsus 2 networks described earlier in this report. The wells in this network are completed at various depths ranging from about 13 to $1,125 \mathrm{ft}$ (appendix 2, table 2.1). The wells were open to these aquifers across intervals of 5 to about $370 \mathrm{ft}$, but most (75 percent) were open across intervals of less than $40 \mathrm{ft}$ (appendix 2, table 2.2). Samples for the VFPS were collected June-November 2018, and these data are available in Kingsbury and others (2020).

\section{Glacial Aquifer System Vertical Flow-Path Study Network (glacvfps2)}

The glacial aquifer system VFPS network (glacvfps2; fig. 34) was designed to add an age framework to results from decadal networks in the glacial aquifer system to help describe changes in water quality over time. The glacvfps 2 network is a group of 32 wells that is a combination of 14 wells from the eiwaluscr 1 network and 18 wells from the eiwasus 2 network described earlier in this report. Wells range in depth from about 12 to $196 \mathrm{ft}$ (appendix 2, table 2.1). The wells were open to the aquifer across intervals of 4 to $20 \mathrm{ft}$, but most were open across intervals of less than $10 \mathrm{ft}$ (appendix 2, table 2.2). Samples for the VFPS were collected May-October 2017, and the data are available in Kingsbury and others (2020).

\section{Northern Atlantic Coastal Plain Aquifer System Vertical Flow-Path Study Network (nacpvfps1)}

The Northern Atlantic Coastal Plain aquifer system VFPS (nacpvfps1; fig. 35) is in the unconfined surficial KirkwoodCohansey aquifer system and was designed to add an age framework to results from decadal networks in the Northern Atlantic Coastal Plain aquifer system to help address questions of changes in water quality over time in the Glassboro, N.J., area. The nacpvfps 1 network consists of 28 monitoring wells that are part of the linjlusrc1 urban land-use network previously described in this report (ranging in depth from about 15 to $70 \mathrm{ft}$ ). An additional 28 public-supply wells also are part of this network and are deeper, ranging from about 70 to $180 \mathrm{ft}$ in depth (appendix 2, table 2.1). The monitoring wells are typically open to the aquifer across 2-ft intervals, and the public-supply wells have open intervals from 15 to $60 \mathrm{ft}$ (appendix 2, table 2.2). Samples were collected from June to November 2017, and the data are available in Kingsbury and others (2020).

\section{Modeling Support Study Networks}

MSS networks are used to support modeling efforts where more data are needed to calibrate a model. They are designed based on a specific need so that each is somewhat unique in its design. Typically, these networks are sampled one time to provide data for the model. Data from the Mississippi Embayment aquifer system MSS network (misemss 1; fig. 36) and the Mississippi River Valley alluvial aquifer MSS network (mrvamss1; fig. 37) are included Kingsbury and others (2020).

\section{Mississippi Embayment Aquifer System Modeling Support Study Network (misemss1)}

The Mississippi Embayment aquifer system MSS network (misemss 1; fig. 36) in the Mississippi River Valley in parts of Arkansas, Mississippi, Tennessee, Louisiana, and Kentucky was designed to collect additional reductionoxidation (redox) sensitive and trace-element constituent data in support of the predictive modeling studies in the Mississippi Embayment aquifer system. The Mississippi Embayment aquifer system consists of thick beds of primarily unconsolidated sand with interbedded layers of silt and clay. A regional upper confining layer, present throughout much of the study area, separates Mississippi Embayment aquifers from the overlying Mississippi River Valley alluvial aquifer. In the study area, the aquifers are part of a thick sequence of sediments that were deposited in a broad structural trough; the aquifers generally dip toward the Mississippi River and thicken in the downdip direction (Renken, 1998). The network consists primarily of public-supply wells that range in depth from 42 to 1,500 ft below land surface (appendix 2, table 2.1). Samples for the model support study were collected August-November 2018, and the data are available in Kingsbury and others (2020).

\section{Mississippi River Valley Alluvial Aquifer Modeling Support Study Networks (mrvamss1)}

The Mississippi River Valley alluvial aquifer MSS (mrvamss1, fig. 37) was designed to collect water-quality data in support of machine-learning model predictions of selected water-quality constituents in this aquifer. Specifically, this network was sampled to broaden the spatial distribution of data for inorganic constituents such as manganese and arsenic and field parameters such as specific conductance, $\mathrm{pH}$, and dissolved oxygen. The Mississippi River Valley alluvial aquifer underlies the Mississippi River Valley, which is a broad, flat floodplain. The aquifer is made up of sand and gravel deposits of Quaternary age that typically are between 25 and $150 \mathrm{ft}$ thick and is a major source of water for irrigation in the region. The upper part of the alluvial plain is made up of fine-grained deposits that represent an upper confining unit that is commonly 20 to $30 \mathrm{ft}$ thick (Renken, 1998). The network consists primarily of 39 wells that range in depth from 30 to $236 \mathrm{ft}$ (appendix 2, table 2.1). Samples for the model support study were collected between July and December 2018, and the data are available in Kingsbury and others (2020). 


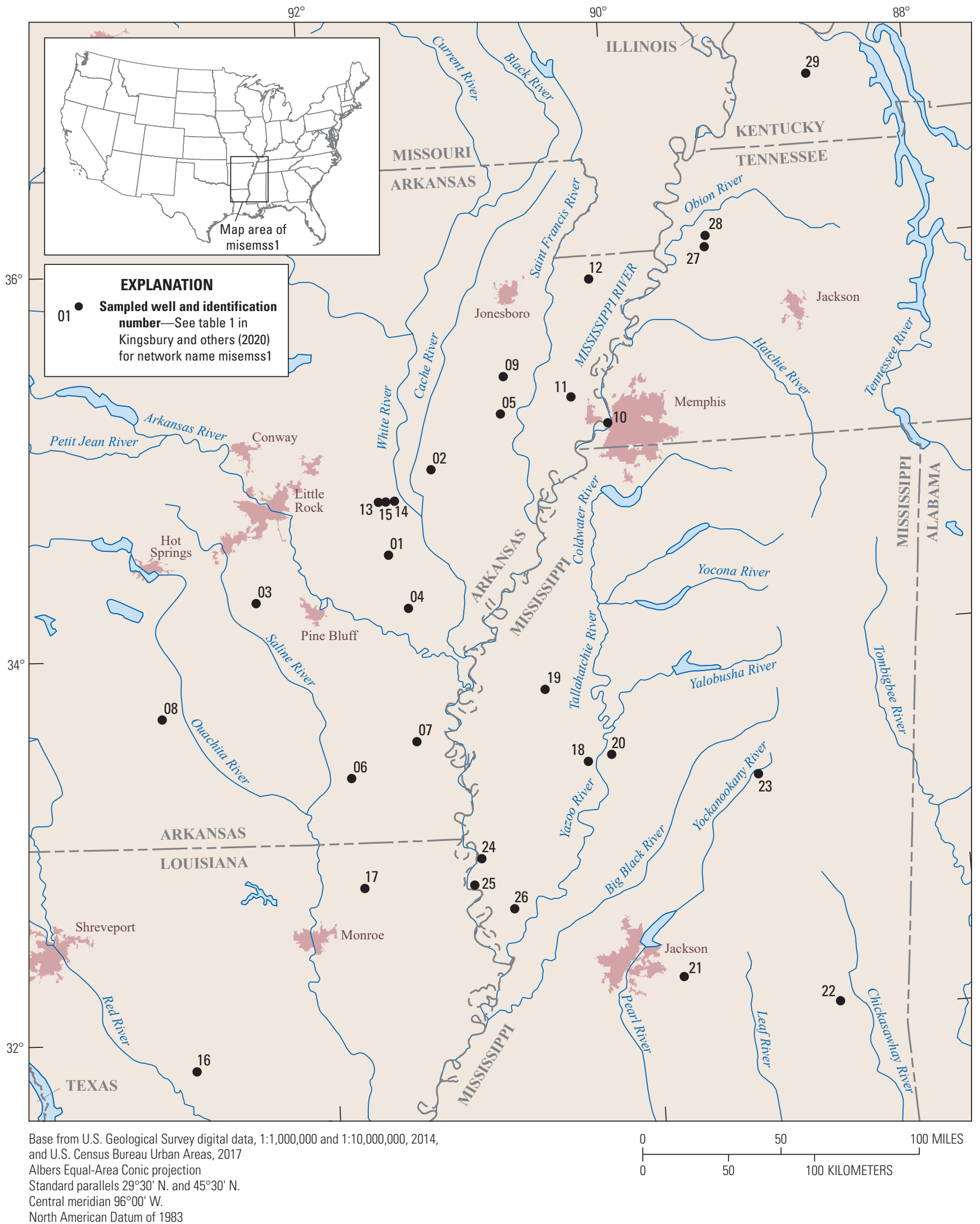

Figure 36. Study area and wells sampled as part of the Mississippi Embayment aquifer system modeling support study network (misemss1) for the U.S. Geological Survey National Water-Quality Assessment Project. 


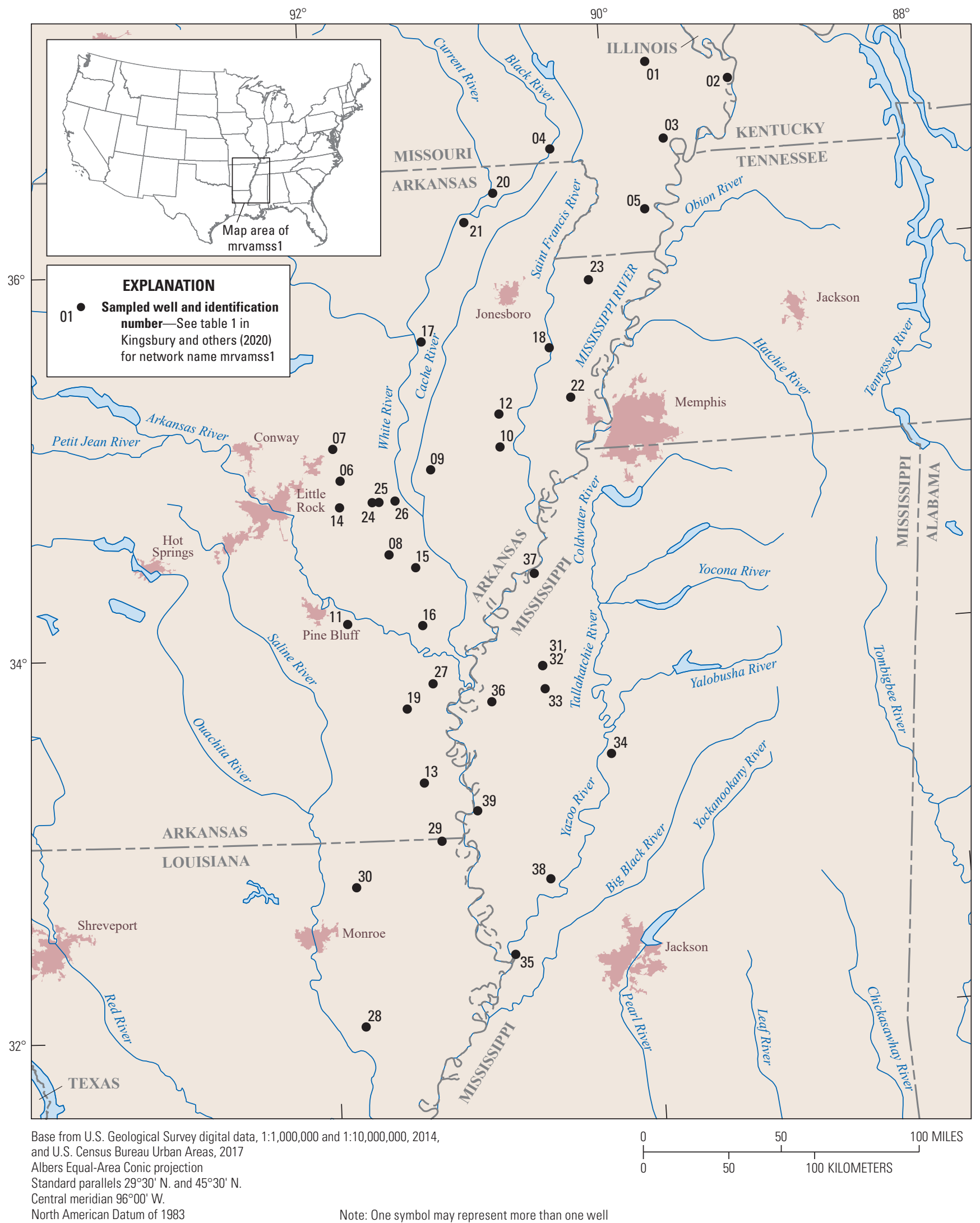

Figure 37. Study area and wells sampled as part of the Mississippi River Valley alluvial aquifer modeling support study network (mrvamss1) for the U.S. Geological Survey National Water-Quality Assessment Project. 


\section{Sample Collection and Analysis}

Water-quality data from samples collected at 983 wells (fig. 1) are available in Kingsbury and others (2020). Groundwater samples were collected and processed using methods designed to yield samples that were representative of environmental conditions, minimally affected by contamination, and consistent nationwide (Koterba and others, 1995; Lapham and others, 1995; USGS, variously dated). All samples were collected at the wellhead (the point at which the groundwater exits the well near land surface) or as close to the wellhead as possible. This location was selected so that samples were collected before any treatment or blending potentially could alter constituent concentrations. Samples were collected and processed using prescribed protocols described in Koterba and others (1995), Lapham and others (1995), and the USGS National Field Manual (USGS, variously dated). Samples were analyzed at the USGS National Water Quality Laboratory (NWQL) in Denver, Colorado, for water-quality indicators, nutrients and dissolved organic carbon (DOC), major and minor ions, trace elements, VOCs, pesticides, radon radiochemistry, and one item of special interest, arsenic speciation. Three radionuclide constituent concentrations (radium-224, radium-226, and radium-228) were analyzed by ALS Environmental in Fort Collins, Colo. Microbiological indicators (total coliforms, Escherichia coli [E. coli] and Enterococci, and somatic and F-specific coliphage) were analyzed at the USGS Ohio Water Microbiology Laboratory in Columbus, Ohio. Perchlorate concentrations were analyzed by Weck Laboratories, Inc., in Industry, California. Hexavalent chromium concentrations were analyzed by the USGS Trace Metal Laboratory in Boulder, Colo. Strontium isotopes were analyzed by the Metal and Metalloid Isotope Research Laboratory in Menlo Park, Calif.

The constituents for which samples were collected are listed in table 2 of Kingsbury and others (2020) and are organized by constituent class, constituent primary uses and sources, analytical schedules and sampling period, analytical method references, USGS parameter codes, comparison thresholds, reporting levels for the sampling period, number of analyses, and the table in which the data for the constituent class are provided. The reporting levels provided are for the samples collected during 2017 to 2019. Reporting levels for earlier data are documented in Arnold and others (2016b, 2017a, 2018a, 2020b). Analytical schedules are groups of constituents for which laboratory analysis is requested. The USGS parameter code identifies the constituents, and the method reference indicates the laboratory method used to analyze the samples. The reported concentration of a constituent can be evaluated using the comparison threshold value. Of the comparison thresholds listed in table 2 of Kingsbury and others (2020), only the secondary maximum contaminant level is not health based.

In addition to discrete water-quality samples that are collected periodically, the ETN wells also are instrumented to measure basic water-quality parameters at a high frequency during specific periods throughout each day. Each well is instrumented with a water-quality sonde that contains temperature, specific conductance, $\mathrm{pH}$, and dissolved oxygen probes. Some wells also are instrumented to measure nitrate. The sonde sits in a flow-through chamber that receives groundwater flow from near the wellhead. Measurements of the basic water-quality parameters are made when the well is pumping and groundwater is flowing through the system, which may range from 1 to 24 hours per day. Water-quality data are recorded by the sonde at different intervals, from 2 minutes to 12 hours, depending on the network. The water-quality data are transmitted to a data-collection platform where the data are stored and transmitted to the USGS National Water Information System (USGS, 2020d) database by the Geostationary Operational Environmental Satellite network. The high-frequency data are reviewed, corrected, and approved according to recommendations for publishing continuous water-quality records (Wagner and others, 2006).

\section{Data Reporting}

Laboratories use specified values, referred to as reporting levels, in reporting results determined during analysis of water samples. Different reporting levels are used depending on the constituent and the laboratory method used to analyze the sample. Concentrations not measured above a certain threshold concentration for that constituent are reported as less than the reporting level; these are censored data.

Reporting levels are defined differently by the NWQL for inorganic and organic constituents. Inorganic constituents (major ions, nutrients, and trace elements) for samples analyzed between 2017 and 2019 are each reported using a reporting level that is equivalent to the detection limit (DL). The DL is the smallest concentration that can be measured and reported with 99-percent confidence that the concentration is greater than zero, which means a less than or equal to 1-percent chance of a false positive (Williams and others, 2015). The DLs used for inorganic and organic constituents generally were determined using the DQCALC method described in Williams and others (2015); this is indicated as DLDQC in table 2 of Kingsbury and others (2020). However, for a few constituents that have commonly been detected in laboratory blank samples, the DLs were determined using an approach that calculates a DL directly from blank data (Williams and others, 2015); this is indicated as DLBLNK in table 2 of Kingsbury and others (2020). Organic constituents (VOCs and pesticides) are each reported using a reporting level that typically is about twice, but may be more than twice, the DL (Williams and others, 2015); this is indicated by RLDQC in table 2 of Kingsbury and others (2020) when calculated from a DL determined using the DQCALC method. This approach to setting the reporting level is estimated to limit the chance of incorrectly reporting the constituent as absent to less than or equal to 1 percent (Williams and others, 
2015). In other words, there is at least a 99-percent confidence that the constituent really is absent from the sample when it is reported relative to the reporting level. The reporting levels are used for reporting analytical results for VOCs and pesticides to allow for the robust analysis and interpretation of detection frequencies. The NWQL uses information-rich analytical methods such as gas chromatography or high-performance liquid chromatography for these constituents and often provides results that indicate the presence of these constituents at concentrations less than their reporting levels, and even at concentrations less than their DLs.

A few constituents are reported using minimum reporting levels (MRLs). The MRLs are calculated according to the EPA definition of an MRL, described previously as the minimum concentration of a substance that can be measured and reported with 99-percent confidence that the value is greater than zero (Oblinger Childress and others, 1999). A minimum reporting level is a reporting level that is chosen by the laboratory.

Radionuclides are reported using units of radioactive activity (picocuries per liter) rather than concentration. Reporting levels for these constituents are based on the sample-specific critical level $\left(\mathrm{ssL}_{\mathrm{c}}\right)$ or sample-specific minimum detectable concentrations (ssMDCs) (McCurdy and others, 2008). The $\mathrm{ssL}_{\mathrm{c}}$ and ssMDC are calculated for each sample from parameter values used during the actual analysis of the sample. The ssLc and ssMDC are analogous to the $\mathrm{DL}$ and reporting level, respectively. The $\mathrm{ssL}_{\mathrm{c}}$ is defined as the smallest measured activity that indicates detection of the radionuclide, with no more than a 5-percent chance of a false positive detection (EPA, 2004). The specified probability associated with a critical level can vary, but it is typically 5 percent for radionuclides. Like the DL, the $s s_{\mathrm{c}}$ is a reporting level that is based on a specified probability of false positive errors; that is, incorrectly reporting that the radionuclide is present. The ssMDC, like the reporting level, is a reporting level that is based on a specified probability of false negative errors; that is, failing to report that the radionuclide is present. The ssMDC is defined as the activity at which there is a 5-percent chance of a false negative error and typically is about two times greater than the $\mathrm{ssL}_{\mathrm{c}}$ (McCurdy and others, 2008).

Concentrations less than DLs, and concentrations between DLs and reporting levels, are reported without any qualifiers. Concentrations less than DLs or between DLs and reporting levels can be identified by comparing the reported concentrations with the DLs and reporting levels listed by compound in table 2 of Kingsbury and others (2020). It is important to note that there is greater uncertainty associated with values less than DLs (regarding risk of false positive errors or inaccurate detections) and with values less than reporting levels (regarding risk of false negative values or inaccurate nondetections) than with values that are greater than DLs, reporting levels, or both.

The data presented in the associated data release (Kingsbury and others, 2020) are current as of the date of retrieval (April 2, 2020) from the National Water Information
System (USGS, 2020d). Results included in this data release had the status of either "reviewed and accepted" or "presumed satisfactory" in the National Water Information System. The well information and water-quality data presented in this report and the associated data release were reviewed by USGS personnel and subsequently verified by coauthors who are responsible for tracking the data.

\section{Quality-Assurance and Quality-Control Methods}

The quality-assurance plan for NAWQA Project groundwater samples was derived from previous NAWQA Project cycles of study (Koterba and others, 1995) and the USGS National Field Manual (USGS, variously dated). About 14 percent of samples collected during any period are for data quality assurance and quality control (QC). Types of QC samples include equipment blanks, source solution blanks, field blanks, replicates, field spikes, and laboratory spikes. Data and results from statistical analysis of blank QC samples are presented in appendix 5 (tables 5.1 and 5.2).

Blanks are used to test for bias from an unintentional introduction of contamination to environmental samples. Equipment blanks are used to test if equipment is clean and free of contamination. Source solution blanks are used to test if the water used for the blank sample is free of contamination. Field blanks are used to test for contamination that may be introduced during sample collection, processing, handling, and analysis. Field blanks also are used to test for contamination from the environment around where the sample was collected. Replicates are samples that are collected at the same time and using the same method as the environmental sample. Replicates measure the variability of determining a concentration in samples that should be almost identical. Spiked samples are used to measure the performance of analytical methods on an environmental water sample. A sample can be spiked in the field or the laboratory.

The number and type of QC samples planned for each network study depend on the number of wells sampled, the number of sampling teams that are involved in the sampling, and the constituents for which samples will be analyzed, as described in the following criteria:

- Equipment blanks are collected for nutrients, trace elements, and VOCs at the quantity of one blank for each team sampling the network.

- Source solution blanks are collected for nutrients, trace elements, and VOCs at the quantity of one blank for each team sampling the network. The VOCs have additional source solution blanks that are collected with each field blank. 
- Field blanks are collected for major ions, nutrients, DOC, trace elements, and pesticides at the quantity of 1 blank for every 15 wells sampled or 1 blank for each team sampling the network (whichever results in a greater number of blanks). Field blanks are collected for VOCs at the quantity of 1 blank for every 10 wells sampled or 1 blank for each team sampling the network (whichever results in a greater number of blanks).

- Replicate samples are collected for major ions, nutrients, DOC, trace elements, VOCs, and radionuclides at the quantity of 1 replicate for every 30 wells sampled. Replicate samples are collected for pesticides at the quantity of 1 replicate for every 15 wells.

- Field spikes are collected for pesticides at the quantity of 1 spike sample for every 30 wells sampled.

- Laboratory spikes are collected for VOCs and trace elements at the quantity of 1 spike sample for every 30 wells sampled.

Statistical analysis of QC sample data can be used to evaluate the variability or bias of the data, sampling and sample handling procedures, and laboratory and (or) field methods and to ensure the environmental assessment samples represent true groundwater chemistry. The QC sample data provided in Kingsbury and others (2020) include water quality for blank QC samples collected between January 2017 and December 2019 in association with the environmental sample data and a few results from earlier sampling periods that were not previously published. Data from the 2012-13 sampling period are presented in Arnold and others (2016a, b), data from the 2014 sampling period are presented in Arnold and others (2017a, b), data from the 2015 sampling period are presented in Arnold and others (2018a, b), and data from the 2016 sampling period are presented in Arnold and others (2020a, b).

\section{Groundwater-Quality Data}

Groundwater-quality data from 983 wells are included in the accompanying data release (table 1 of Kingsbury and others, 2020). Samples were analyzed for 383 constituents (table 2 of Kingsbury and others, 2020); however, not all wells were sampled for all constituents. Results of analyses are presented in tables 3-14 of Kingsbury and others (2020), which are organized by constituent class: water-quality indicators (table 3); nutrients and DOC (table 4); major and minor ions (table 5); trace elements (table 6); VOCs (table 7); pesticides (table 8); radiochemistry (table 9); microbiological indicators (table 10); and special-interest constituents, including arsenic speciation (table 11), hexavalent chromium (table 12), perchlorate (table 13), and strontium isotopes (table 14). The constituents for which samples were analyzed and the table in which the data are presented are listed in table 2 of Kingsbury and others (2020). Comparative benchmarks (thresholds) listed in that table provide context for evaluating the constituent concentration data in terms of human health and other characteristics relevant for drinking-water use. Several types of thresholds are listed. The EPA maximum contaminant levels are legally enforceable drinking-water standards that specify the maximum permissible level of a constituent that can be delivered to a user of a public water system. The EPA humanhealth benchmarks for pesticides (HHBPs) are nonenforceable screening levels for evaluating if a pesticide concentration in drinking-water sources may indicate a potential humanhealth risk (EPA, 2012). The HHBPs include benchmarks for cancer and noncancer health effects (EPA, 2013). The USGS health-based screening levels are nonenforceable benchmarks for constituents that do not have maximum contaminant levels or HHBPs that can be used to evaluate if constituent concentrations may indicate a potential human-health concern (Toccalino, 2007; Norman and others, 2018). Like EPA HHBPs, USGS health-based screening levels are categorized in terms of cancer and noncancer health effects.

The groundwater-quality data from January 2017 to December 2019 are presented in the format of tab-delimited American Standard Code for Information Interchange text files and are available for download from Kingsbury and others (2020), including complete metadata files that describe the contents of each text file. The data may be imported into spreadsheet, database, or statistical software for manipulation and analysis. The data available in Kingsbury and others (2020) are referenced as tables 1-14 and appendix tables 5.11-5.20.

\section{Water-Quality Indicators}

Water-quality indicators include water temperature, dissolved oxygen, specific conductance, $\mathrm{pH}$, alkalinity, carbonate and bicarbonate (calculated from alkalinity), and turbidity (table 3 of Kingsbury and others, 2020). Water-quality indicators are measured in the field when the other water samples are collected (USGS, variously dated), and $\mathrm{pH}$ and specific conductance sometimes also are measured in the laboratory.

Water-quality indicators provide basic information about the general quality and geochemical conditions of the water. Dissolved oxygen is the concentration of oxygen dissolved in the water and is an indicator of reduction-oxidation (redox) conditions in the aquifer. Measurements of $\mathrm{pH}$ indicate the acidity or basicity of water. Dissolved oxygen and $\mathrm{pH}$ are important controls on the chemical reactions that can happen in water. Specific conductance is a measure of how well the water conducts electricity and indicates the relative amount of dissolved solids in the water. Alkalinity, carbonate, and bicarbonate indicate the hardness of water and are related to $\mathrm{pH}$. Turbidity is a measure of the suspended solids in the water. 


\section{Inorganic Constituents}

Inorganic constituents are most commonly naturally present in groundwater. Groundwater samples were analyzed for the following inorganic constituent classes: major and minor ions, nutrients and DOC, and trace elements (including metals; tables 4-6 of Kingsbury and others, 2020).

Nutrients include nitrogen and phosphorus compounds and DOC. Data for ammonia, nitrate plus nitrite, nitrite, total nitrogen, and phosphorus measured as orthophosphate are presented in table 4 of Kingsbury and others (2020). Nutrients are present naturally, but nutrient concentrations also are affected by human activities such as farming and wastewater disposal (Hem, 1985). Nitrogen was measured as total nitrogen and as the individual nitrogen species of nitrite, nitrate, and ammonia. Nutrient concentrations can affect the quality of groundwater for use as drinking water.

Major and minor ions are cations and anions that can be dissolved in water from geologic materials. Concentrations of major and minor ions can be used to classify water into different types (Hem, 1985; Hiscock, 2005). Waters with similar ion concentrations commonly have similar history, recharge areas, climate, mineralogy, and residence time (Güler and others, 2002). Some major ions can affect the quality of water for drinking and other uses. Groundwater samples were analyzed for 10 major and minor ions and total dissolved solids (table 5 of Kingsbury and others, 2020).

Trace elements consist of metals that are usually present in the environment in small quantities (Hem, 1985). Trace elements commonly are dissolved in water from geologic materials, but concentrations of these elements also can be affected by human activities such as mining. Many trace elements can affect the quality of groundwater for use as drinking water. Groundwater samples were analyzed for 22 trace elements (table 6 of Kingsbury and others, 2020).

\section{Organic Compounds}

Organic compounds are man-made chemicals and include VOCs and pesticides. VOCs are chemicals that tend to evaporate into the air and are in a variety of substances including disinfectants, solvents, paint, fumigants, asphalt, and fuel additives (Zogorski and others, 2006). Pesticides are chemical compounds used to control plant or insect pests and include fungicides, herbicides, and insecticides (Gilliom and others, 2006). Many VOCs and pesticides, if present, can affect the quality of groundwater used for drinking water. Groundwater samples were analyzed for 85 VOCs and 225 pesticides (tables 7 and 8 of Kingsbury and others, 2020).

\section{Radiochemistry}

Radiochemical constituents include radionuclides and measurements of radioactivity. Radionuclides are chemical constituents that are produced naturally by the decay of radioactive parent elements such as uranium and thorium. Sources of radionuclides in groundwater are geologic material such as rocks and soils (Hem, 1985). Radionuclides and measurements of radioactivity are $\alpha$ radioactivity, $\beta$ radioactivity, radon (a dissolved gas), and several isotopes of radium (radium-224, radium-226, and radium-228) (table 9 of Kingsbury and others, 2020). Uranium, which also is a radionuclide, is included with trace elements (table 6 of Kingsbury and others, 2020) because uranium is measured in units of mass concentration rather than as units of radioactivity. In total, groundwater samples were analyzed for six radionuclides and measures of radioactivity.

\section{Microbiological Indicators}

Microbiological indicators include bacteria and viruses that may be indicative of fecal contamination or susceptibility to contamination in water resources (Myers and others, 2014). Indicators analyzed in groundwater samples included three types of bacteria: total coliforms, E. coli, and Enterococci (table 10 of Kingsbury and others, 2020). Total coliforms are common in the environment and their presence is not necessarily associated with fecal contamination, but it can be an indication of groundwater susceptibility to fecal contamination. In contrast, the presence of $E$. coli and commonly Enterococci indicate contamination (Myers and others, 2014). Somatic and F-specific coliphages are viruses that infect and replicate coliform bacteria, and their presence in groundwater can indicate the presence of bacteria and may indicate the presence of pathogenic viruses (Bushon, 2003).

\section{Constituents of Special Interest}

Several constituents of special interest were included for selected networks. Constituents of special interest were arsenic species (arsenate, arsenite, monomethylarsonate, and dimethylarsinate), which are derived from arsenic, hexavalent chromium, perchlorate, and strontium isotopes $(87 \mathrm{Sr} / 86 \mathrm{Sr})$ (tables 11-14 of Kingsbury and others, 2020). Arsenic and chromium are predominantly natural in origin but may have localized anthropogenic sources. Anthropogenic arsenic uses include metal and ore processing, glass production, fossil fuel combustion, wood preservatives, pesticides, semiconductor production, and pharmaceuticals (Garelick and others, 2008). Hexavalent chromium is chromium in the +6 oxidation state (six electrons lost from the atom) and is used in textile dyes, wood preservation, anticorrosive agents, and other surface coatings (Nriagu and Niebor, 1988). Geochemical conditions such as redox and $\mathrm{pH}$ affect the speciation of chromium and arsenic in groundwater (Hem, 1985). Most arsenic and chromium in groundwater is from geologic sources in rocks and soils. Perchlorate is an inorganic constituent used in rocket fuels, fireworks, safety flares, and other products; it is present in some fertilizers and may be present naturally at low concentrations in groundwater (Srinivasan and Sorial, 2009; 
Jackson and others, 2015). Strontium isotope variations in groundwater provide insight into the sources of dissolved constituents to groundwater and have been used to trace flow paths and mineral-solution reactions in soils and aquifer rocks (Banner, 2004).

\section{Summary}

As part of the third decadal cycle of the U.S. Geological Survey National Water-Quality Assessment Project, groundwater-quality data are being collected from well networks to assess water-quality conditions in the Nation's principal aquifers and investigate changes in groundwater-quality conditions in selected land use and hydrogeologic settings. Groundwater-quality data are published in annual data series reports, of which this report is the fifth in the series.

Groundwater-quality data from 983 wells were collected from 6 types of well networks: principal aquifer study networks, land-use study networks, major aquifer study networks, enhanced trends networks, vertical flow-path study networks, and modeling support studies. Within principal aquifer, land-use, and major aquifer study networks, study areas were divided into equal-area grids and wells were selected for sampling using a stratified random sampling design. The number of wells in principal aquifer networks ranged from about 40 to 60 wells per network for the studies included in this report. About 30 wells typically made up each land-use or major aquifer study network. Enhanced trends networks that were sampled in 2017 through 2019 consisted of two to five wells that were selected at locations within aquifers where temporal changes in groundwater quality might be expected. Four vertical flow-path study networks and two modeling support studies are described in this report.

Groundwater samples were analyzed for water-quality indicators and constituents, including nutrients, major and minor ions, trace elements, volatile organic compounds, pesticides, radiochemistry, microbiological indicators, and select special-interest constituents such as arsenic speciation, hexavalent chromium (chromium [VI]), and perchlorate. These groundwater-quality data are tabulated in an associated U.S. Geological Survey data release. Quality-control samples were collected during the collection of selected environmental samples, and data from blank quality-control samples also are included in this report. The data release includes data collected during 2017 through 2019 and includes samples from one network that were collected in 2016 .

\section{Acknowledgments}

Many people in addition to the authors participated in providing information for this report. Bryant Jurgens and Tyler Johnson (both with the U.S. Geological Survey) provided tools for data compilation.

\section{References Cited}

Anderson, H.W., Jr., 1993, Effects of agricultural and residential land use on ground-water quality, Anoka Sand Plain aquifer, east-central Minnesota: U.S. Geological Survey Water-Resources Investigations Report 93-4074, 62 p. [Also available at https://doi.org/10.3133/wri934074.]

Anderson, T.W., Freethey, G.W., and Tucci, P., 1992, Geohydrology and water resources of alluvial basins in south-central Arizona and parts of adjacent states: U.S. Geological Survey Professional Paper 1406-B, 67 p., 3 pls. [Also available at https://doi.org/10.3133/pp1406B.]

Andrews, W.J., Fong, A.L., Harrod, L., and Dittes, M.E., 1998, Water-quality assessment of part of the Upper Mississippi River Basin, Minnesota and Wisconsin-Ground-water quality in an urban part of the Twin Cities metropolitan area, Minnesota, 1996: U.S. Geological Survey WaterResources Investigations Report 97-4248, 54 p. [Also available at https://doi.org/10.3133/wri974248.]

Arnold, T.L., Bexfield, L.M., Musgrove, M., Erickson, M.L., Kingsbury, J.A., Degnan, J.R., Tesoriero, A.J., Kulongoski, J.T., and Belitz, K., 2020a, Groundwater-quality and select quality-control data from the National Water-Quality Assessment Project, January through December 2016, and previously unpublished data from 2013 to 2015: U.S. Geological Survey Data Series 1124, 135 p., accessed June 2020 at https://doi.org/10.3133/ds1124.

Arnold, T.L., Bexfield, L.M., Musgrove, M., Lindsey, B.D., Stackelberg, P.E., Barlow, J.R., DeSimone, L.A., Kulongoski, J.T., Kingsbury, J.A., Ayotte, J.D., Fleming, B.J., and Belitz, K., 2017a, Datasets from groundwaterquality data from the National Water-Quality Assessment Project, January through December 2014 and select qualitycontrol data from May 2012 through December 2014: U.S. Geological Survey data release, accessed March 28, 2018, at https://doi.org/10.5066/F7W0942N.

Arnold, T.L., Bexfield, L.M., Musgrove, M., Lindsey, B.D., Stackelberg, P.E., Barlow, J.R., DeSimone, L.A., Kulongoski, J.T., Kingsbury, J.A., Ayotte, J.D., Fleming, B.J., and Belitz, K., 2017b, Groundwater-quality data from the National Water-Quality Assessment Project, January through December 2014 and select quality-control data from May 2012 through December 2014: U.S. Geological Survey Data Series 1063, 83 p., accessed March 28, 2018, at https://doi.org/10.3133/ds1063.

Arnold, T.L., Bexfield, L.M., Musgrove, M., Stackelberg, P.E., Lindsey, B.D., Barlow, J.R., Kulongoski, J.T., and Belitz, K., 2018a, Datasets from groundwaterquality and select quality-control data from the National Water-Quality Assessment Project, January through December 2015 and previously unpublished data from 2013-2014: U.S. Geological Survey data release, accessed September 4, 2019, at https://doi.org/10.5066/F7XK8DHK. 
Arnold, T.L., Bexfield, L.M., Musgrove, M., Stackelberg, P.E., Lindsey, B.D., Kingsbury, J.A., Kulongoski, J.T., and Belitz, K., 2018b, Groundwater-quality and select qualitycontrol data from the National Water-Quality Assessment Project, January through December 2015, and previously unpublished data from 2013 to 2014: U.S. Geological Survey Data Series 1087, 67 p., accessed January 2020 at https://doi.org/10.3133/ds1087.

Arnold, T.L., DeSimone, L.A., Bexfield, L.M., Lindsey, B.D., Barlow, J.R., Kulongoski, J.T., Musgrove, M., Kingsbury, J.A., and Belitz, K., 2016a, Groundwater quality data from the National Water-Quality Assessment Project, May 2012 through December 2013: U.S. Geological Survey Data Series 997, 56 p., accessed March 28, 2018, at https://doi.org/10.3133/ds997.

Arnold, T.L., DeSimone, L.A., Bexfield, L.M., Lindsey, B.D., Barlow, J.R., Kulongoski, J.T., Musgrove, M., Kingsbury, J.A., and Belitz, K., 2016b, Groundwater quality data from the National Water Quality Assessment Project, May 2012 through December 2013: U.S. Geological Survey data release, accessed March 28, 2018, at https://doi.org/ 10.5066/F7HQ3X18.

Arnold, T.L., Sharpe, J.B., Bexfield, L.M., Musgrove, M., Erickson, M.L., Kingsbury, J.A., Degnan, J.R., Tesoriero, A.J., Kulongoski, J.T., and Belitz, K., 2020b, Datasets from groundwater-quality and select quality-control data from the National Water-Quality Assessment Project, January through December 2016, and previously unpublished data from 2013 to 2015: U.S. Geological Survey data release, accessed April 2020 at https://doi.org/ 10.5066/P9W4RR74.

Ayers, M.A., Kennen, J.G., and Stackelberg, P.E., 2000, Water quality in the Long Island-New Jersey coastal drainages, New York and New Jersey, 1996-98: U.S. Geological Survey Circular 1201, 40 p. [Also available at https://doi.org/10.3133/cir1201.]

Banner, J.L., 2004, Radiogenic isotopes-Systematics and applications to earth surface processes and chemical stratigraphy: Earth-Science Reviews, v. 65, no. 3-4, p. 141-194. [Also available at https://doi.org/10.1016/ S0012-8252(03)00086-2.]

Belitz, K., Dubrovsky, N.M., Burow, K., Jurgens, B., and Johnson, T., 2003, Framework for a ground-water quality monitoring and assessment program for California: U.S. Geological Survey Water-Resources Investigations Report 03-4166, 78 p. [Also available at https://doi.org/ 10.3133/wri034166.]
Belitz, K., Fram, M.S., and Johnson, T.D., 2015, Metrics for assessing the quality of groundwater used for public supply, CA, USA - Equivalent-population and area: Environmental Science \& Technology, v. 49, no. 14, p. 8330-8338. [Also available at https://doi.org/10.1021/acs.est.5b00265.]

Belitz, K., Jurgens, B., Landon, M.K., Fram, M.S., and Johnson, T., 2010, Estimation of aquifer scale proportion using equal area grids-Assessment of regional scale groundwater quality: Water Resources Research, v. 46, no. 11, art. W11550, 14 p, accessed March 15, 2017, at https://doi.org/10.1029/2010WR009321.

Bennett, G.L.V., Fram, M.S., and Belitz, K., 2011, Status of groundwater quality in the Southern, Middle, and Northern Sacramento Valley study units, 2005-08-California GAMA Priority Basin Project: U.S. Geological Survey Scientific Investigations Report 2011-5002, 120 p. [Also available at https://doi.org/10.3133/sir20115002.]

Bloomgren, B.A., Cleland, J.M., and Olsen, B.M., 1989, Depth to bedrock and bedrock topography, in Balaban, N.H., ed., 1989, Geologic atlas of Hennepin County, Minnesota: Minnesota Geological Survey, County Atlas Series, C $-4,9$ pls.

Burow, K.R., and Belitz, K., 2014, Groundwater studiesPrincipal aquifer surveys: U.S. Geological Survey Fact Sheet 2014-3024, 2 p., accessed January 4, 2016, at https://doi.org/10.3133/fs20143024.

Bushon, R.N., 2003, Fecal indicator viruses (3d ed.): U.S. Geological Survey Techniques of Water-Resources Investigations, book 9, chap. A, sec. 7.2, 22 p., accessed April 2020 at https://doi.org/10.3133/twri09A7.2.

California Department of Water Resources, 2015, California's groundwater update 2013-A compilation of enhanced content for California water plan update 2013: State of California, Natural Resources Agency, 90 p., accessed May 12, 2020, at https://cawaterlibrary.net/document/californiasgroundwater-update-2013-a-compilation-of-enhancedcontent-for-california-water-plan-update-2013/.

Cordy, G.E., Gellenbeck, D.J., Gebler, J.B., Anning, D.W., Coes, A.L., Edmonds, R.J., Rees, J.A.H., and Sanger, H.W., 2000, Water quality in the Central Arizona Basins, Arizona, 1995-98: U.S. Geological Survey Circular 1213, 38 p. [Also available at https://doi.org/10.3133/cir1213.]

Davidson, E.S., 1979, Summary appraisals of the Nation's ground-water resources - Lower Colorado region: U.S. Geological Survey Professional Paper 813-R, 23 p., 3 pls. [Also available at https://doi.org/10.3133/pp813R.] 
Dawson, B.J., 2001, Shallow ground-water quality beneath rice areas in the Sacramento Valley, California, 1997: U.S. Geological Survey Water-Resources Investigations Report 2001-4000, 33 p. [Also available at https://doi.org/ 10.3133/wri014000.]

Delin, G.N., and Woodward, D.G., 1984, Hydrogeologic setting and the potentiometric surfaces of regional aquifers in the Hollandale Embayment, southeastern Minnesota, 1970-80: U.S. Geological Survey Water-Supply Paper 2219, 56 p. [Also available at https://doi.org/10.3133/wsp2219.]

Denver, J.M., Ator, S.W., Fischer, J.M., Harned, D.C., Schubert, C., and Szabo, Z., 2014, The quality of our Nation's waters - Water quality in the Northern Atlantic Coastal Plain surficial aquifer system, Delaware, Maryland, New Jersey, New York, North Carolina, and Virginia, 1988-2009: U.S. Geological Survey Circular 1353, 88 p., accessed January 4, 2016, at https://doi.org/10.3133/cir 1353.

Domagalski, J.L., Knifong, D.L., MacCoy, D.E., Dileanis, P.D., Dawson, B.J., and Majewski, M.S., 1998, Water quality assessment of the Sacramento River Basin, CaliforniaEnvironmental setting and study design: U.S. Geological Survey Water-Resources Investigations Report 97-4254, 31 p. [Also available at https://doi.org/10.3133/wri974254.]

Edmonds, R.J., and Gellenbeck, D.J., 2002, Ground-water quality in the West Salt River Valley, Arizona 1996-98Relations to hydrogeology, water use, and land use: U.S. Geological Survey Water-Resources Investigation Report 2001-4126, 58p. [Also available at https://doi.org/10.3133/ wri014126.]

Fong, A.L., Andrews, W.J., and Stark, J.R., 1998, Waterquality assessment of part of the Upper Mississippi River Basin, Minnesota and Wisconsin-Ground-water quality in the Prairie du Chien-Jordan Aquifer, 1996: U.S. Geological Survey Water-Resources Investigations Report 98-4248, 45 p. [Also available at https://doi.org/10.3133/wri984248.]

Friedel, M.J., 1998, National Water-Quality Assessment Program-Upper Illinois River Basin: U.S. Geological Survey Fact Sheet 072-98, 4 p., accessed September 2019 at https://doi.org/10.3133/fs07298.

Garelick, H., Jones, H., Agnieszka, D., and Valsami-Jones, E., 2008, Arsenic pollution sources, in Garelick, H., and Jones, H., eds., Reviews of environmental contamination and toxicology-Arsenic pollution and remediation-An international perspective: New York, Springer-Verlag, Reviews of Environmental Contamination and Toxicology v. 197, p. $17-60$.
George, P.G., Mace, R.E., and Petrossian, R., 2011, Aquifers of Texas: Texas Water Development Board, Report 380, 172 p., accessed January 5, 2018, at http://www.twdb.texas.gov/ publications/reports/numbered_reports/doc/R380_ AquifersofTexas.pdf?d=5431.47.

Gilliom, R.J., Alley, W.M., and Gurtz, M.E., 1995, Design of the National Water-Quality Assessment ProgramOccurrence and distribution of water-quality conditions: U.S. Geological Survey Circular 1112, 33 p., accessed March 1, 2016, at https://doi.org/10.3133/cir1112.

Gilliom, R.J., Barbash, J.E., Crawford, C.G., Hamilton, P.A., and Martin, J.D., Nakagaki, N., Nowell, L.H., Scott, J.C., Stackelberg, P.E., Thelin, G.P., and Wolock, D.M., 2006, The quality of our Nation's waters - Pesticides in the Nation's streams and ground water, 1992-2001: U.S. Geological Survey Circular 1291, 172 p., accessed August 9, 2017, at https://doi.org/10.3133/cir1291.

Glover, K.C., Naftz, D.L., and Martin, L.J., 1998, Geohydrology of Tertiary rocks in the upper Colorado River basin in Colorado, Utah, and Wyoming, excluding the San Juan basin: U.S. Geological Survey Water-Resources Investigations Report 96-4105, 103 p. [Also available at https://doi.org/10.3133/wri964105.]

Güler, C., Thyne, G.D., McCray, J.E., and Turner, K.A., 2002, Evaluation of graphical and multivariate statistical methods for classification of water chemistry data: Hydrogeology Journal, v. 10, no. 4, p. 455-474. [Also available at https://doi.org/10.1007/s10040-002-0196-6.]

Helgesen, J.O., and Lindholm, G.F., 1977, Geology and water-supply potential of the Anoka Sand Plain aquifer, Minnesota: Minnesota Department of Natural Resources, Technical Paper No. 6, 17 p.

Hem, J.D., 1985, Study and interpretation of the chemical characteristics of natural water ( $3 \mathrm{~d}$ ed.): U.S. Geological Survey Water-Supply Paper 2254, 263 p., 3 pls. [Also available at https://doi.org/10.3133/wsp2254.]

Hiscock, K.M., 2005, Hydrogeology-Principles and practice: United Kingdom, Blackwell Publishing, 389 p.

Homer, C.G., Dewitz, J.A., Yang, L., Jin, S., Danielson, P., Xian, G.Z., Coulston, J., Herold, N.D., Wickham, J.D., and Megown, K., 2015, Completion of the 2011 National Land Cover Database for the conterminous United StatesRepresenting a decade of land cover change information: Photogrammetric Engineering and Remote Sensing, v. 81, no. 5, p. 345-354. 
Hughes, W.B., Abrahamsen, T.A., Maluk, T.L., Reuber, E.J., and Wilhelm, L.J., 2000, Water quality in the Santee River basin and coastal drainages, North and South Carolina, 1995-98: U.S. Geological Survey Circular 1206, 32 p. [Also available at https://doi.org/10.3133/cir1206.]

Inkpen, E.L., Tesoriero, A.J., Ebbert, J.C., Silva, S.R., and Sandstrom, M.W., 2000, Ground-water quality in regional, agricultural, and urban settings in the Puget Sound Basin, Washington and British Columbia, 1996-1998: U.S. Geological Survey Water-Resources Investigations Report 2000-4100, 66 p. [Also available at https://doi.org/ 10.3133/wri004100.]

Jackson, W.A., Böhlke, J.K., Andraski, B.J., Fahlquist, L., Bexfield, L., Eckardt, F.D., Gates, J.B., Davila, A.F., McKay, C.P., Rao, B., Sevanthi, R., Rajagopalan, S., Estrada, N., Sturchio, N., Hatzinger, P.B., Anderson, T.A., Orris, G., Betancourt, J., Stonestrom, D., Latorre, C., Li, Y., and Harvey, G.J., 2015, Global patterns and environmental controls of perchlorate and nitrate co-occurrence in arid and semi-arid environments: Geochimica et Cosmochimica Acta, v. 164, p. 502-522. [Also available at https://doi.org/10.1016/j.gca.2015.05.016.]

Kempton, J.P., Johnson, W.H., Heigold, P.C., and Cartwright, K., 1991, Mahomet Bedrock Valley in east-central IllinoisTopography, glacial drift stratigraphy, and hydrogeology, in Melhorn, W.N., and Kempton, J.P., eds., Geology and hydrogeology of the Teays-Mahomet Bedrock Valley System, 1991: Geological Society of America Special Paper 258, p. 91-124.

Kingsbury, J.A., Sharpe, J.B., Bexfield, L.M., Arnold, T.L., Musgrove, M., Erickson, M.L., Degnan, J.R., Tesoriero, A.J., Lindsey, B.D., and Belitz, K., 2020, Datasets of groundwater-quality and select quality-control data from the National Water-Quality Assessment Project, January 2017 through December 2019 (ver. 1.1, January 2021): U.S. Geological Survey data release, https://doi.org/10.5066/ P9XATXV1.

Koterba, M.T., Wilde, F.D., and Lapham, W.W., 1995, Groundwater data-collection protocols and procedures for the National Water-Quality Assessment ProgramCollection and documentation of water-quality samples and related data: U.S. Geological Survey Open-File Report 95-399, 114 p., accessed January 4, 2016, at https://doi.org/10.3133/ofr95399.

Lapham, W.W., Wilde, F.D., and Koterba, M.T., 1995, Ground-water data-collection protocols and procedures for the National Water-Quality Assessment ProgramSelection, installation, and documentation of wells, and collection of related data: U.S. Geological Survey OpenFile Report 95-398, 71 p., accessed January 4, 2016, at https://doi.org/10.3133/ofr95398.
Lindholm, G.F., 1980, Ground-water appraisal of sand plains in Benton, Sherburne, Stearns, and Wright Counties, central Minnesota: U.S. Geological Survey Water-Resources Investigations Report 80-1285, 103 p., 4 pls. [Also available at https://doi.org/10.3133/ofr801285.]

Lloyd, O.B., Jr., and Lyke, W.L., 1995, Ground water atlas of the United States - Segment 10, Illinois, Indiana, Kentucky, Ohio, Tennessee: U.S. Geological Survey Hydrologic Investigations Atlas 730-K, 30 p. [Also available at https://doi.org/10.3133/ha730K.]

Lovelace, J.K., Nielsen, M.G., Read, A.L., Murphy, C.J., and Maupin, M.A., 2020, Estimated groundwater withdrawals from principal aquifers in the United States, 2015: U.S. Geological Survey Circular 1464, 70 p. [Also available at https://doi.org/10.3133/cir1464.]

Maclay, R.W., and Small, T.A., 1983, Hydrostratigraphic subdivisions and fault barriers of the Edwards aquifer, southcentral Texas, USA, in Back, W., and LaMoreaux, P.E., eds., V.T. Stringfield Symposium-Processes in Karst hydrology: Journal of Hydrology, v. 61, no. 1-3, p. 127-146. [Also available at https://doi.org/10.1016/0022-1694(83)90239-1.]

Masterson, J.P., Pope, J.P., Monti, J., Jr., Nardi, M.R., Finkelstein, J.S., and McCoy, K.J., 2013, Hydrogeology and hydrologic conditions of the Northern Atlantic Coastal Plain aquifer system from Long Island, New York, to North Carolina (ver. 1.1, September 2015): U.S. Geological Survey Scientific Investigations Report 2013-5133, 76 p., accessed January 4, 2016, at https://doi.org/10.3133/sir2013 5133.

Maupin, M.A., and Barber, N.L., 2005, Estimated withdrawals from principal aquifers in the United States, 2000: U.S. Geological Survey Circular 1279, 46 p., accessed January 4, 2016, at https://doi.org/10.3133/cir1279.

McCurdy, D.E., Garbarino, J.R., and Mullin, A.H., 2008, Interpreting and reporting radiological water-quality data: U.S. Geological Survey Techniques and Methods, book 5, chap. B6, 33 p., accessed January 4, 2016, at https://doi.org/ 10.3133/tm5B6.

Meyer, G.N., and Hobbs, H.C., 1989, Surficial geology, in Balaban, N.H., ed., Geologic atlas of Hennepin County, Minnesota: Minnesota Geological Survey, County Atlas Series, C $-4,9$ pls.

Miller, J.A., 1986, Hydrogeologic framework of the Floridan aquifer system in Florida and in parts of Georgia, South Carolina, and Alabama: U.S. Geological Survey Professional Paper 1403-B, 91 p., 33 pls. [Also available at https://doi.org/10.3133/pp1403B.]

Miller, J.A., 1990, Ground water atlas of the United StatesSegment 6, Alabama, Florida, Georgia, South Carolina: U.S. Geological Survey Hydrologic Atlas 730-G, 28 p., accessed January 4, 2016, at https://doi.org/10.3133/ha730G. 
Miller, J.A., and Appel, C.L., 1997, Ground water atlas of the United States-Segment 3, Kansas, Missouri, Nebraska: U.S. Geological Survey Hydrologic Atlas 730-D, 24 p., accessed December 12, 2017, at https://doi.org/10.3133/ ha730D.

Morrow, W.S., 2001, Uranium and radon in ground water in the lower Illinois River Basin: U.S. Geological Survey Water-Resources Investigations Report 2001-4056, 29 p. [Also available at https://doi.org/10.3133/wri014056.]

Myers, D.N., Stoeckel, D.M., Bushon, R.N., Francy, D.S., and Brady A.M.G., 2014, Fecal indicator bacteria: U.S. Geological Survey Techniques of Water-Resources Investigations, book 9, chap. A, sec. 7.1, 73 p., accessed April 2020 at https://doi.org/10.3133/twri09A7.1.

Norman, J.E., Toccalino, P.L., and Morman, S.A., 2018, Health-based screening levels for evaluating water-quality data (2d ed.): U.S. Geological Survey National WaterQuality Assessment Program web page, accessed April 2020 at https://doi.org/10.5066/F71C1TWP.

Nriagu, J.O., and Niebor, E., eds., 1988, Chromium in the natural and human environments: New York, John Wiley \& Sons, $571 \mathrm{p}$.

Oblinger Childress, C.J., Forman, W.T., Connor, B.F., and Maloney, T.J., 1999, New reporting procedures based on long-term method detection levels and some considerations for interpretations of water-quality data provided by the U.S. Geological Survey National Water Quality Laboratory: U.S. Geological Survey Open-File Report 99-193, 19 p., accessed January 4, 2016, at https://doi.org/10.3133/ ofr99193.

Olcott, P.G., 1992, Ground water atlas of the United StatesSegment 9, Iowa, Michigan, Minnesota, Wisconsin: U.S. Geological Survey Hydrologic Atlas 730-J, 31 p. [Also available at https://doi.org/10.3133/ha730J.]

Olcott, P.G., 1995, Ground water atlas of the United StatesSegment 12, Connecticut, Maine, Massachusetts, New Hampshire, New York, Rhode Island, Vermont: U.S. Geological Survey Hydrologic Atlas 730-M, 28 p. [Also available at https://doi.org/10.3133/ha730M.]

Parks, W.S., 1990, Hydrogeology and preliminary assessment of the potential for contamination of the Memphis aquifer in the Memphis area, Tennessee: U.S. Geological Survey Water-Resources Investigations Report 90-4092, 39 p. [Also available at https://doi.org/10.3133/wri904092.]

Planert, M., and Williams, J.S., 1995, Ground water atlas of the United States-Segment 1, California, Nevada: U.S. Geological Survey Hydrologic Atlas 730-B, 28 p. [Also available at https://doi.org/10.3133/ha730B.]
Pope, D.A., Carleton, G.B., Buxton, D.E., Walker, R.L., Shourds, J.L., and Reilly, P.A., 2012, Simulated effects of alternative withdrawal strategies on groundwater flow in the unconfined Kirkwood-Cohansey aquifer system, the Rio Grande water-bearing zone, and the Atlantic City 800-foot sand in the Great Egg Harbor and Mullica River Basins, New Jersey: U.S. Geological Survey Scientific Investigations Report 2012-5187, 139 p., accessed February 2020 at https://doi.org/10.3133/sir20125187.

Renken, R.A., 1998, Ground water atlas of the United States-Segment 5, Arkansas, Louisiana, Mississippi: U.S. Geological Survey Hydrologic Atlas 730-F, 28 p. [Also available at https://doi.org/10.3133/ha730F.]

Robson, S.G., and Banta, E.R., 1995, Ground water atlas of the United States - Segment 2: Arizona, Colorado, New Mexico, Utah, U.S. Geological Survey Hydrologic Atlas 730-C, 32 p. [Also available at https://doi.org/ 10.3133/ha730C.]

Rowe, G.L., Jr., Belitz, K., Demas, C.R., Essaid, H.I., Gilliom, R.J., Hamilton, P.A., Hoos, A.B., Lee, C.J., Munn, M.D., and Wolock, D.W., 2013, Design of Cycle 3 of the National Water-Quality Assessment Program, 2013-23Part 2-Science plan for improved water-quality information and management: U.S. Geological Survey Open File Report 2013-1160, 110 p., accessed January 4, 2016, at https://doi.org/10.3133/ofr20131160.

Rowe, G.L., Jr., Belitz, K., Essaid, H.I., Gilliom, R.J., Hamilton, P.A., Hoos, A.B., Lynch, D.D., Munn, M.D., and Wolock, D.W., 2010, Design of Cycle 3 of the National Water-Quality Assessment Program, 2013-2023Part 1-Framework of water-quality issues and potential approaches: U.S. Geological Survey Open-File Report 2009-1296, 54 p., accessed January 4, 2016, at https://doi.org/10.3133/ofr20091296.

Ruhl, J.F., Fong, A.L., Hanson, P.E., and Andrews, W.J., 2000, Water-quality assessment of part of the Upper Mississippi River Basin, Minnesota and Wisconsin-Ground-water quality in an agricultural area of Sherburne County, Minnesota, 1998: U.S. Geological Survey Water-Resources Investigations Report 2000-4107, 33 p. [Also available at https://doi.org/10.3133/wri20004107.]

Rupert, M.G., 1997, Nitrate $\left(\mathrm{NO}_{2}+\mathrm{NO}_{3}-\mathrm{N}\right)$ in ground water of the Upper Snake River Basin, Idaho and Western Wyoming, 1991-95: U.S. Geological Survey Water-Resources Investigations Report 97-4174, 56 p. [Also available at https://doi.org/10.3133/wri974174.]

Ryder, P.D., 1996, Ground water atlas of the United StatesSegment 4, Oklahoma, Texas: U.S. Geological Survey Hydrologic Atlas 730-E, 30 p., accessed December 12, 2017, at https://doi.org/10.3133/ha730E. 
Sargent, B.P., Maupin, M.A., and Hinkle, S.R., 2008, Estimated withdrawals from stream-valley aquifers and refined estimated withdrawals from selected aquifers in the United States, 2000: U.S. Geological Survey Scientific Investigations Report 2008-5003, 71 p. [Also available at https://doi.org/10.3133/sir20085003.]

Savoca, M.E., Sadorf, E.M., Linhart, S.M., and Akers, K.K.B., 2000, Effects of land use and hydrogeology on the water quality of alluvial aquifers in eastern Iowa and southern Minnesota, 1997: U.S. Geological Survey Water-Resources Investigations Report 99-4246, 38 p. [Also available at https://doi.org/10.3133/wri994246.]

Scott, J.C., 1990, Computerized stratified random siteselection approaches for design of a ground-water-quality sampling network: U.S. Geological Survey WaterResources Investigations Report 90-4101, 109 p., accessed January 4, 2016, at https://doi.org/10.3133/wri904101.

Sharp, J.M., and Banner, J.L., 1997, The Edwards aquifer-A resource in conflict - Geological Society of America (GSA): Today, v. 7, p. 1-9.

Shelton, J.L., 2005, Assessment of shallow ground-water quality in recently urbanized areas of Sacramento, California, 1998: U.S. Geological Survey Scientific Investigations Report 2005-5148, 51 p., accessed March 2020 at https://doi.org/10.3133/sir20055148.

Skinner, K.D., and Donato, M.M., 2003, Probability of detecting elevated concentrations of nitrate in ground water in a six-county area of south-central Idaho: U.S. Geological Survey Water-Resources Investigations Report 2003-4143, 29 p., accessed February 2020 at https://doi.org/10.3133/ wri034143.

Srinivasan, R., and Sorial, G.A., 2009, Treatment of perchlorate in drinking water-A critical review: Separation and Purification Technology, v. 69, no. 1, p. 7-21. [Also available at https://doi.org/10.1016/j.seppur.2009.06.025.]

Stackelberg, P.E., and Ayers, M.A., 1994, National WaterQuality Assessment (NAWQA) Program, Long Island-New Jersey (LINJ) coastal drainages study unit: U.S. Geological Survey Fact Sheet 012-94, accessed December 2019 at https://doi.org/10.3133/fs01294.

Steinhilber, W.L., and Horick, P.J., 1970, Ground-water resources of Iowa, in Horick, P.J., ed., Water resources of Iowa: Iowa City, University Printing Service, p. 29-49.

Texas State University, 2020, Edwards Aquifer Research and Data Center-Threatened and endangered species in the Edwards aquifer system: Texas State University web page, accessed May 7, 2020, at https://www.eardc.txstate.edu/ Aquifer-Info/endangered.html.
Toccalino, P.L., 2007, Development and application of healthbased screening levels for use in water-quality assessments: U.S. Geological Survey Scientific Investigations Report 2007-5106, 12 p., accessed January 4, 2016, at https://doi.org/10.3133/sir20075106.

Trapp, H., Jr., and Horn, M.A., 1997, Ground water atlas of the United States-Segment 11, Delaware, Maryland, New Jersey, North Carolina, Pennsylvania, Virginia, West Virginia: U.S. Geological Survey Hydrologic Atlas 730-L, 24 p., accessed January 4, 2016, at https://doi.org/10.3133/ ha730L.

U.S. Census Bureau, 2010, Census of population and housing, 2010: U.S. Census Bureau digital data, accessed March 1, 2018, at https://www.census.gov/prod/www/ decennial.html.

U.S. Census Bureau, 2019, Fastest-growing cities primarily in the South and West: U.S. Census Bureau Press Release, May 23, 2019, accessed May 2020 at https://www.census.gov/newsroom/press-releases/2019/ subcounty-population-estimates.html.

U.S. Environmental Protection Agency, [EPA], 2004, Multiagency radiological laboratory analytical protocols manual (MARLAP) - Part II - Chapters 18-20, appendix G (volume III): U.S. Environmental Protection Agency, EPA 402-B-04-001C, accessed May 19, 2015, at https://nepi s.epa.gov/Exe/ZyPDF.cgi/P10094KI.PDF?Dockey= P10094KI.PDF.

U.S. Environmental Protection Agency, [EPA], 2012, Human health benchmarks for pesticides: U.S. Environmental Protection Agency, EPA 822-F-12-001, accessed May 19, 2015, at https://nepis.epa.gov/Exe/ZyPDF.cgi/ P100E60P.PDF?Dockey=P100E60P.PDF.

U.S. Environmental Protection Agency, [EPA], 2013, Human health benchmarks for pesticides-Updated 2013 technical document: U.S. Environmental Protection Agency, EPA 820-R-13-010, accessed May 19, 2015, at https://nepi s.epa.gov/Exe/ZyPDF.cgi/P100GRDJ.PDF?Dockey= P100GRDJ.PDF.

U.S. Environmental Protection Agency, 2018, Sole source aquifers for drinking water: U.S. Environmental Protection Agency web page, accessed January 9, 2018, at https://www.epa.gov/dwssa.

U.S. Geological Survey, [USGS], 2003, Principal aquifers of the 48 conterminous United States, Hawaii, Puerto Rico, and the U.S. Virgin Islands: U.S. Geological Survey, digital data, accessed January 4, 2016, at https://water.usgs.gov/ GIS/metadata/usgswrd/XML/aquifers_us.xml. 
U.S. Geological Survey, [USGS], 2018, USGS CA GAMAPBP groundwater-quality results-Assessment and trends: U.S. Geological Survey web page, accessed April 2020 at https://doi.org/10.5066/P91WJ2G1.

U.S. Geological Survey, [USGS], 2020a, Decadal change in groundwater quality: U.S. Geological Survey web page, accessed October 21, 2020, at https://nawqatrends.wim .usgs.gov/Decadal/.

U.S. Geological Survey, [USGS], 2020b, Groundwater Ambient Monitoring \& Assessment (GAMA): U.S. Geological Survey web page, accessed June 4, 2020, at https:/ca.water.usgs.gov/gama/.

U.S. Geological Survey, [USGS], 2020c, Rapid fluctuations in groundwater quality: U.S. Geological Survey web page, accessed October 21, 2020, at https://www.usgs.gov/ mission-areas/water-resources/science/rapid-fluctuationsgroundwater-quality?qt-science_center_objects $=0 \#$ qtscience_center_objects.

U.S. Geological Survey, [USGS], 2020d, USGS water data for the Nation: U.S. Geological Survey National Water Information System database, accessed April 2, 2020, at https://doi.org/10.5066/F7P55KJN.

U.S. Geological Survey, [USGS], variously dated, National field manual for the collection of water-quality data: U.S. Geological Survey Techniques of Water-Resources Investigations, book 9, chaps. A1-A9, accessed January 4, 2016, at https://pubs.water.usgs.gov/twri9A.

Visocky, A.P., Sherrill, M.G., and Cartwright, K., 1985, Geology, hydrology, and water quality of the Cambrian and Ordovician systems in northern Illinois: Illinois State Geological Survey, Cooperative Ground Water Report 10, 136 p.

Wagner, R.J., Boulger, R.W., Jr., Oblinger, C.J., and Smith, B.A., 2006, Guidelines and standard procedures for continuous water-quality monitors - Station operation, record computation, and data reporting: U.S. Geological Survey Techniques and Methods, book 1, chap. D3, 51 p., accessed January 4, 2016, at https://pubs.usgs.gov/tm/2006/tm1D3/.
Wahl, K.D., Ludvigson, G.A., Ryan, G.L., and Steinkampf, W.C., 1978, Water resources of east-central Iowa: Iowa Geological Survey Water Atlas 6, 91 p.

Whitehead, R.L., 1992, Geohydrologic framework of the Snake River Plain regional aquifer system, Idaho and eastern Oregon: U.S. Geological Survey Professional Paper 1408-B, 32 p., 6 pls. [Also available at https://doi.org/ 10.3133/pp1408B.]

Williams, T., Foreman, W.T., Decess, J., Reed-Parker, C., and Stevenson, D.L., 2015, Changes to National Water Quality Laboratory (NWQL) procedures used to establish and verify laboratory detection and reporting limits: U.S. Geological Survey, National Water Quality Laboratory Technical Memorandum 15.02, 21 p., accessed January 4, 2016, at https://nwql.usgs.gov/Public/tech_ memos/nwq1.2015-02.pdf.

Young, H.L., 1992a, Hydrogeology of the CambrianOrdovician aquifer system in the northern Midwest, United States, with a section on Ground-water quality, by D.I. Siegel: U.S. Geological Survey Professional Paper 1405-B, 99 p., 1 pl. [Also available at https://doi.org/10.3133/ pp1405B.]

Young, H.L., 1992b, Summary of ground-water hydrology of the Cambrian-Ordovician aquifer system in the northern Midwest, United States: U.S. Geological Survey Professional Paper 1405-A, 55 p. [Also available at https://doi.org/10.3133/pp1405A.]

Zogorski, J.S., Carter, J.M., Ivahnenko, T., Lapham, W.W., Moran, M.J., Rowe, B.L., Squillace, P.J., and Toccalino, P.L., 2006, The quality of our Nation's waters_-Volatile organic compounds in the Nation's ground water and drinking-water supply wells: U.S. Geological Survey Circular 1292, 101 p., accessed January 4, 2016, at https://doi.org/10.3133/cir1292. 


\section{Appendix 1. Information Contained in Previous Reports in This Series}

Table 1.1. Index of reports containing each network description [available for download at https://doi.org/10.3133/ds1136].

\section{References Cited}

Arnold, T.L., Bexfield, L.M., Musgrove, M., Erickson, M.L., Kingsbury, J.A., Degnan, J.R., Tesoriero, A.J., Kulongoski, J.T., and Belitz, K., 2020a, Groundwater-quality and select quality-control data from the National Water-Quality Assessment Project, January through December 2016, and previously unpublished data from 2013 to 2015: U.S. Geological Survey Data Series 1124, 135 p., accessed June 2020 at https://doi.org/10.3133/ds1124.

Arnold, T.L., Bexfield, L.M., Musgrove, M., Lindsey, B.D., Stackelberg, P.E., Barlow, J.R., DeSimone, L.A., Kulongoski, J.T., Kingsbury, J.A., Ayotte, J.D., Fleming, B.J., and Belitz, K., 2017a, Datasets from groundwaterquality data from the National Water-Quality Assessment Project, January through December 2014 and select qualitycontrol data from May 2012 through December 2014: U.S. Geological Survey data release, accessed March 28, 2018, at https://doi.org/10.5066/F7W0942N.

Arnold, T.L., Bexfield, L.M., Musgrove, M., Lindsey, B.D., Stackelberg, P.E., Barlow, J.R., DeSimone, L.A., Kulongoski, J.T., Kingsbury, J.A., Ayotte, J.D., Fleming, B.J., and Belitz, K., 2017b, Groundwater-quality data from the National Water-Quality Assessment Project, January through December 2014 and select quality-control data from May 2012 through December 2014: U.S. Geological Survey Data Series 1063, 83 p., accessed March 28, 2018, at https://doi.org/10.3133/ds1063.

Arnold, T.L., Bexfield, L.M., Musgrove, M., Stackelberg, P.E., Lindsey, B.D., Barlow, J.R., Kulongoski, J.T., and Belitz, K., 2018a, Datasets from groundwater-quality and select quality-control data from the National Water-Quality Assessment Project, January through December 2015 and previously unpublished data from 2013-2014: U.S. Geological Survey data release, accessed September 4, 2019, at https://doi.org/10.5066/F7XK8DHK.
Arnold, T.L., Bexfield, L.M., Musgrove, M., Stackelberg, P.E., Lindsey, B.D., Kingsbury, J.A., Kulongoski, J.T., and Belitz, K., 2018b, Groundwater-quality and select qualitycontrol data from the National Water-Quality Assessment Project, January through December 2015, and previously unpublished data from 2013 to 2014: U.S. Geological Survey Data Series 1087, 67 p., accessed January 2020 at https://doi.org/10.3133/ds1087.

Arnold, T.L., DeSimone, L.A., Bexfield, L.M., Lindsey, B.D., Barlow, J.R., Kulongoski, J.T., Musgrove, M., Kingsbury, J.A., and Belitz, K., 2016a, Groundwater quality data from the National Water Quality Assessment Project, May 2012 through December 2013: U.S. Geological Survey data release, accessed March 28, 2018, at https://doi.org/ 10.5066/F7HQ3X18.

Arnold, T.L., DeSimone, L.A., Bexfield, L.M., Lindsey, B.D., Barlow, J.R., Kulongoski, J.T., Musgrove, M., Kingsbury, J.A., and Belitz, K., 2016b, Groundwater quality data from the National Water-Quality Assessment Project, May 2012 through December 2013: U.S. Geological Survey Data Series 997, 56 p., accessed March 28, 2018, at https://doi.org/10.3133/ds997.

Arnold, T.L., Sharpe, J.B., Bexfield, L.M., Musgrove, M., Erickson, M.L., Kingsbury, J.A., Degnan, J.R., Tesoriero, A.J., Kulongoski, J.T., and Belitz, K., 2020b, Datasets from groundwater-quality and select quality-control data from the National Water-Quality Assessment Project, January through December 2016, and previously unpublished data from 2013 to 2015: U.S. Geological Survey data release, accessed April 2020 at https://doi.org/10.5066/P9W4RR74.

Kingsbury, J.A., Sharpe, J.B., Bexfield, L.M., Arnold, T.L., Musgrove, M., Erickson, M.L., Degnan, J.R., Tesoriero, A.J., Lindsey, B.D., and Belitz, K., 2020, Datasets of groundwater-quality and select quality-control data from the National Water-Quality Assessment Project, January 2017 through December 2019 (ver. 1.1, January 2021): U.S. Geological Survey data release, https://doi.org/10.5066/ P9XATXV1. 


\section{Appendix 2. Well Depth and Open Interval by Study Network}




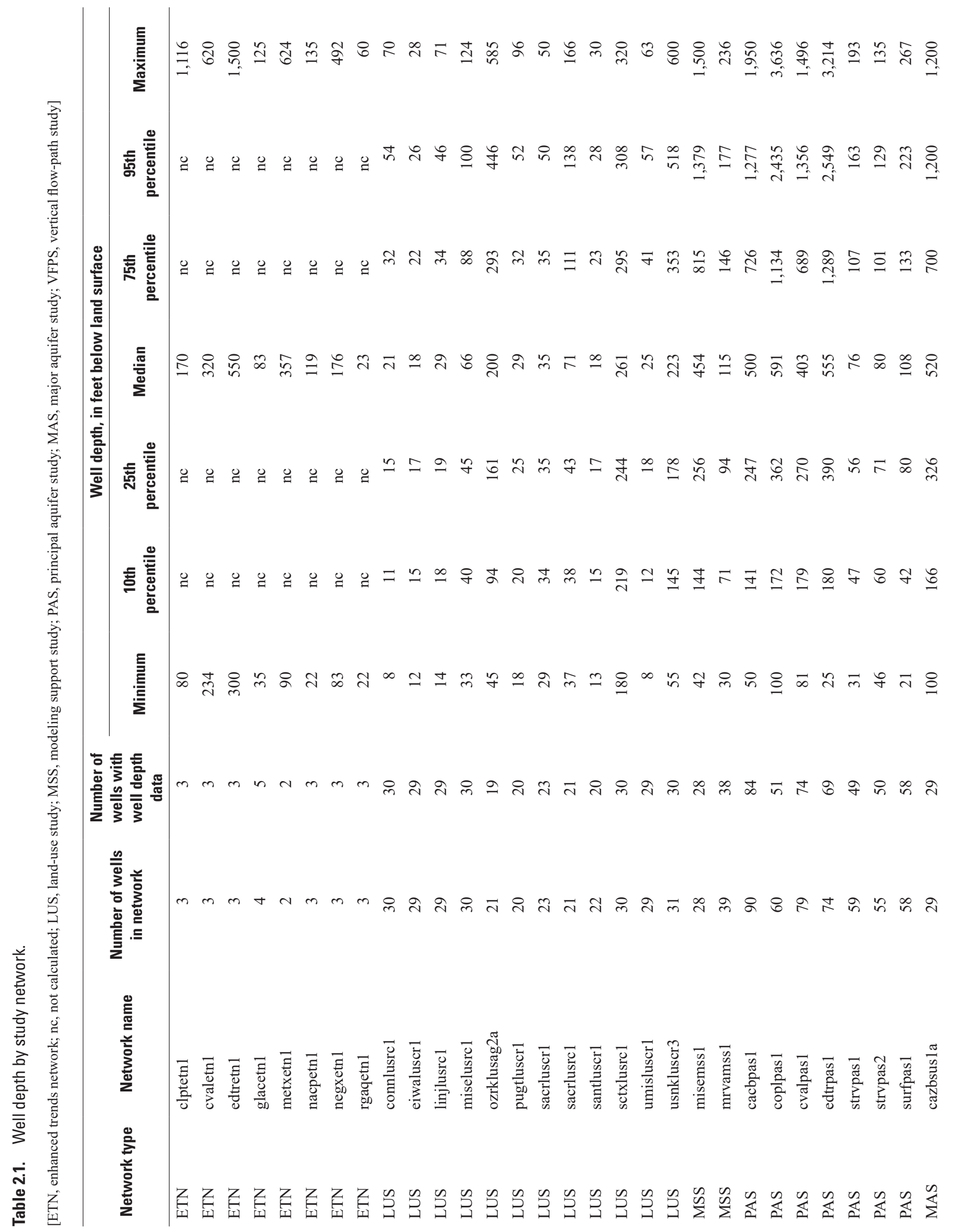




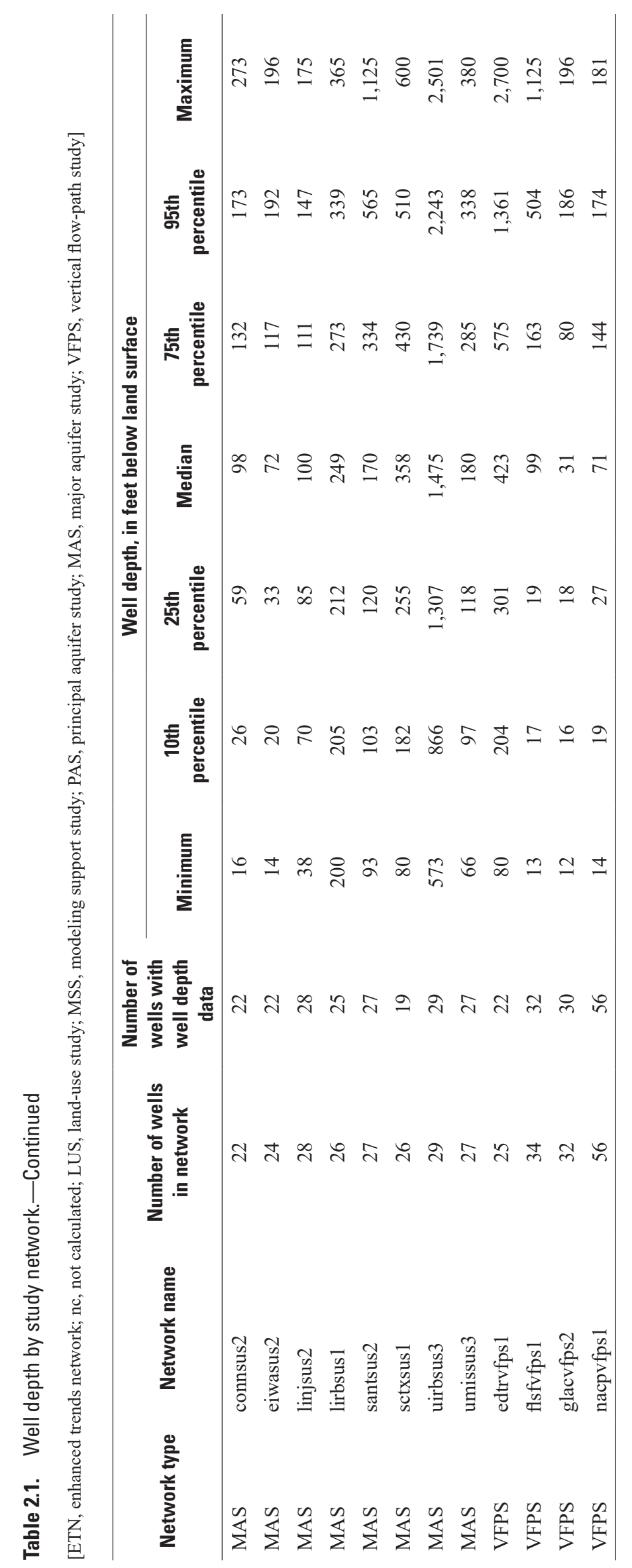


Table 2.2. Length of open interval by study network.

[ETN, enhanced trends network; nc, not calculated; LUS, land-use study; MSS, modeling support study; PAS, principal aquifer study; MAS, major aquifer study; VFPS, vertical flow-path study]

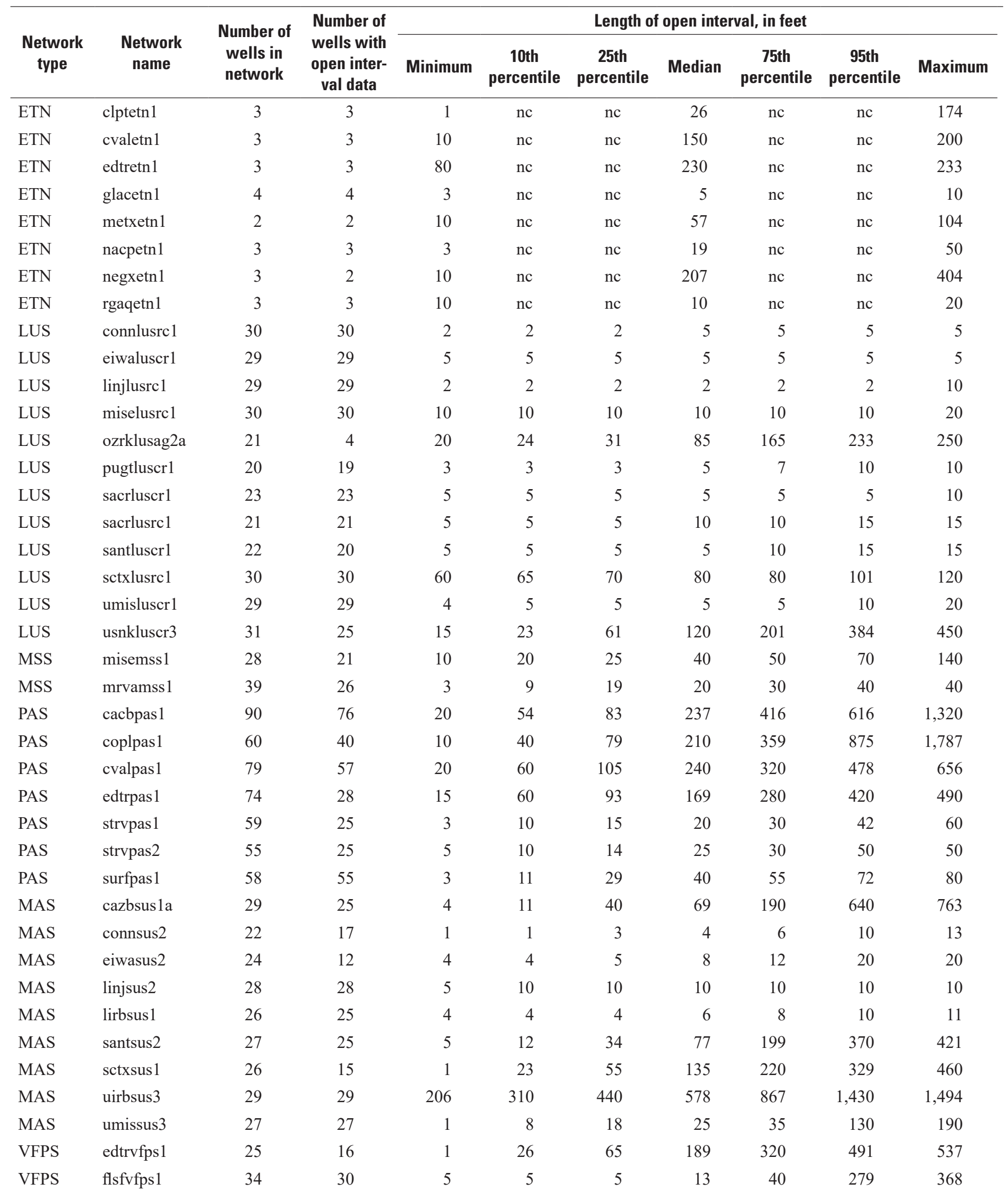


Table 2.2. Length of open interval by study network.-Continued

[ETN, enhanced trends network; nc, not calculated; LUS, land-use study; MSS, modeling support study; PAS, principal aquifer study; MAS, major aquifer study; VFPS, vertical flow-path study]

\begin{tabular}{|c|c|c|c|c|c|c|c|c|c|c|}
\hline \multirow[b]{2}{*}{$\begin{array}{l}\text { Network } \\
\text { type }\end{array}$} & \multirow{2}{*}{$\begin{array}{c}\text { Network } \\
\text { name }\end{array}$} & \multirow{2}{*}{$\begin{array}{l}\text { Number of } \\
\text { wells in } \\
\text { network }\end{array}$} & \multirow{2}{*}{$\begin{array}{c}\text { Number of } \\
\text { wells with } \\
\text { open inter- } \\
\text { val data }\end{array}$} & \multicolumn{7}{|c|}{ Length of open interval, in feet } \\
\hline & & & & Minimum & $\begin{array}{c}\text { 10th } \\
\text { percentile }\end{array}$ & $\begin{array}{c}\text { 25th } \\
\text { percentile }\end{array}$ & Median & $\begin{array}{c}\text { 75th } \\
\text { percentile }\end{array}$ & $\begin{array}{c}\text { 95th } \\
\text { percentile }\end{array}$ & Maximum \\
\hline VFPS & nacpvfps1 & 56 & 55 & 2 & 2 & 2 & 10 & 30 & 40 & 60 \\
\hline
\end{tabular}




\section{Appendix 3. Well Identification Numbers and Reports Containing Sample Results for Wells in the California Coastal Basin Aquifers and Central Valley Aquifer System Principal Aquifer Study Networks}

Table 3.1. Well identification numbers, Groundwater Ambient Monitoring and Assessment study unit, and report with water-quality data for wells in the California Coastal Basin aquifers and Central Valley aquifer system principal aquifer study networks [available for download at https://doi.org/10.3133/ds1136]. 


\section{Appendix 4. High-Frequency Data from Enhanced Trends Networks}

High-frequency data collected at enhanced trends network sites are available from the U.S. Geological Survey National Water Information System (U.S. Geological Survey, 2020) online database (table 4.1). The links in table 4.1 provide access to the high-frequency data on the web. To access the data for the period covered by this report, the user should open the National Water Information System web page at https://doi.org/10.5066/F7P55KJN. The user should then change the begin and end dates to retrieve the data for the period January 1, 2017, to December 31, 2019.

Some of the enhanced trends network sites may have different equipment installed and may collect different parameters than other sites. Additionally, some sites have missing records for various parameters because of equipment failures at various times during the data-collection period.

Table 4.1. Web links to selected data collected at a high frequency from enhanced trends networks.

[See figures 30-31 of this report for locations of enhanced trends networks. NAWQA, National Water-Quality Assessment]

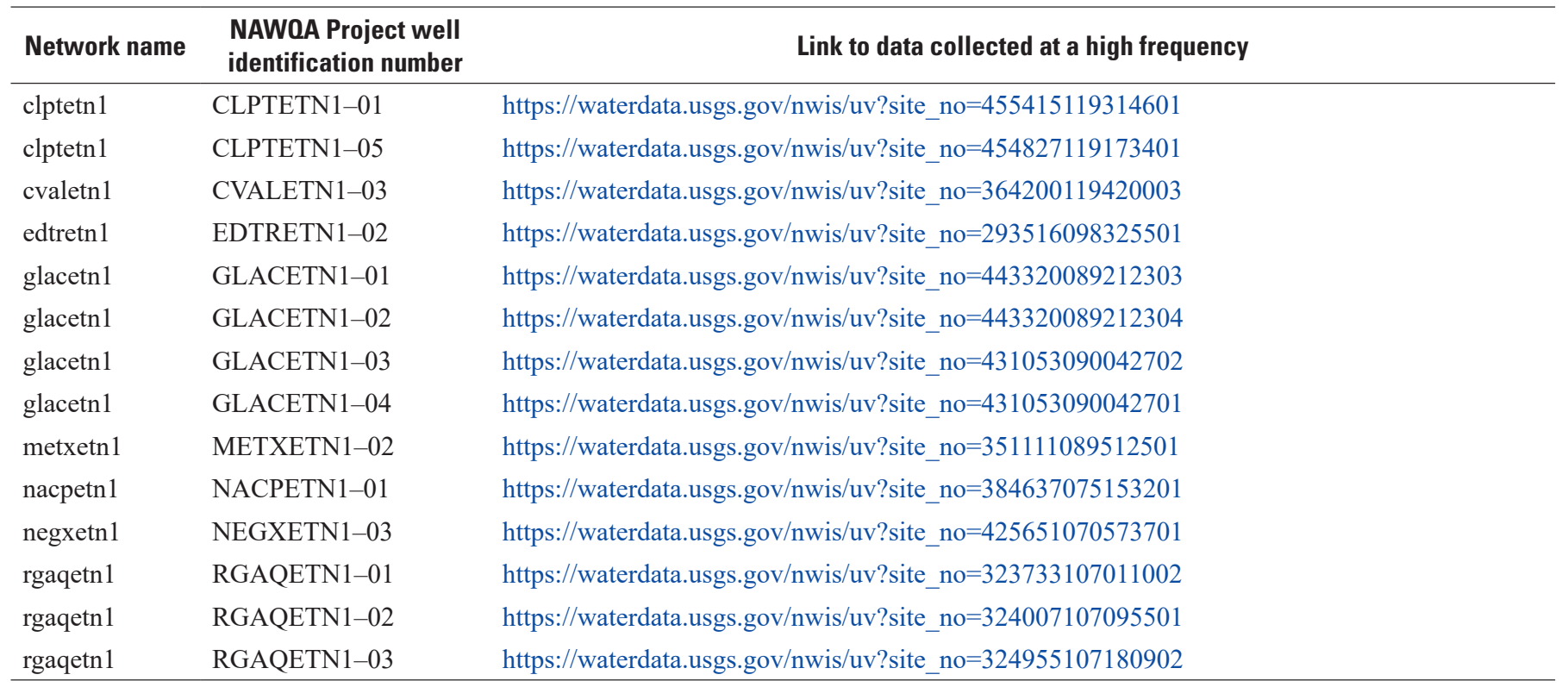

\section{Reference Cited}

U.S. Geological Survey, 2020, USGS water data for the Nation: U.S. Geological Survey National Water Information System database, accessed April 2, 2020, at https://doi.org/ 10.5066/F7P55KJN. 


\section{Appendix 5. Quality-Control Data and Analysis}

\section{Samples}

Quality-control (QC) samples are routinely collected along with the environmental groundwater samples. The third cycle of the National Water-Quality Assessment (NAWQA) groundwater studies began in 2013, but there was a small pilot study in 2012. The third cycle sampling period currently is May 2012-December 2018; this period is hereafter referred to as "the cycle 3 sampling period." Data from the environmental and QC blank and replicate samples from the 2012-13 sampling period were presented in Arnold and others (2016a, b), and data from the 2014 sampling period were presented in Arnold and others (2017a, b); the Arnold and others (2017a, b) publications also presented data for selected spike samples collected in 2012-14. Data from the environmental and QC blank samples from the 2015 sampling period were presented in Arnold and others (2018a, b). Data from the environmental and QC blank, replicate, and spike samples from the 2016 sampling period, along with data from the QC replicate and spike samples from the 2015 sampling period, were presented in Arnold and others (2020a, b). This section of the current report presents a summary of QC samples from the cycle 3 sampling period (May 2012-December 2018). Data for QC samples collected in 2019 for the enhanced trends networks are published in Kingsbury and others (2020) but are not included in the discussion or tables presented in this section. In addition, no QC data and no QC evaluation for pesticide compounds are published in this report because a detailed evaluation of QC samples collected in May 2013-September 2018 for pesticide compounds is presented in Bexfield and others (2020). Finally, data for QC samples collected for microbiological constituents in January 2016-December 2018 are published and discussed in this report.

For all constituents included in the QC evaluation presented in this section of the report, a summary of results from blank samples collected during the sampling period January 2017-December 2018 is provided in table 5.1, and a summary for the cycle 3 sampling period is provided in table 5.2. A summary of replicate samples, an analysis of the variability in detections and concentrations of selected analytes from replicate samples, and a summary of spike samples for the sampling period May 2012-December 2018 are provided in tables 5.3 through 5.10. Data from the QC samples from the January 2017-December 2018 sampling period are presented in tables 5.11-5.19 of Kingsbury and others (2020).

Data users should be aware that method and (or) instrument changes have been implemented during cycle 3 for dissolved organic carbon (DOC) and trace elements. A method validation study for the new DOC method implemented on October 1, 2017, is discussed in National Water Quality Laboratory Technical Memorandum 2018.02 (http://wwwnwql.cr.usgs.gov/tech_memos/nwql.2018-02.pdf, accessed April 20,2020). An instrument validation study for the new trace-element instruments deployed on October 1, 2016, is discussed in National Water Quality Laboratory Technical Memorandum 2018.01 (http://wwwnwql.cr .usgs.gov/tech_memos/nwq1.2018-01.pdf, accessed April 20, 2020). The comparability of results across methods and instrumentation is not examined as part of the QC evaluation presented here because it is addressed by these memoranda.

\section{Blank-Sample Approach}

Blank samples are QC samples that are used to determine if water samples might become contaminated during sample collection, field processing, transport, or laboratory analysis. Blank samples are collected using water that has been prepared to be free of detectable concentrations of the constituents of interest. An equipment blank generally is collected in a controlled environment (such as a laboratory) before field sampling begins and is intended to evaluate the suitability of the equipment and equipment cleaning protocols for the established data-quality requirements. A field blank is subjected to all the same aspects of sample collection, field processing, preservation, transportation, and laboratory handling as an environmental sample and is intended to evaluate the potential for these procedures to be sources of contamination. A source solution blank is a sample of the water used to collect the equipment and field blanks and is intended to verify that the blank water itself has no detectable concentrations of the constituents of interest. Because field blanks are collected under conditions most comparable to conditions affecting environmental samples, these blanks are most directly representative of potential sources of contamination to environmental samples and were the focus of this initial evaluation of blank-sample results.

Results of the initial evaluation of data from field blanks for major and trace elements, nutrients, and volatile organic compounds (VOCs) collected during sampling period of January 2017-December 2018 and the cycle 3 sampling period are presented in this report. About 70 to 75 percent of the field blanks collected for each of these constituents during the cycle 3 sampling period have been associated with groundwater sites that are sampled using a dedicated pump (primarily public-supply and domestic wells), and the rest have been associated with groundwater sites that are sampled using a portable sampling pump (monitoring wells). The objective of this initial evaluation of field blanks was to determine if environmental concentrations of these constituents as reported by the relevant laboratories are suitable for comparison to their corresponding human-health benchmarks 
(HHBs) or to U.S. Environmental Protection Agency secondary maximum contaminant levels (SMCLs) if HHBs have not been established. The HHBs are a set of health-based comparison thresholds that include U.S. Environmental Protection Agency maximum contaminant levels, health-based screening levels (HBSLs), and human-health benchmarks for pesticides. Further evaluation of results for blank samples, such as through methods used by Olsen and others (2010), Bender and others (2011), Fram and others (2012), Davis and others (2014), or Bexfield and others (2020), would be needed to determine if inadvertent contamination of samples with certain constituents would affect the interpretation of environmental concentrations of those constituents for objectives other than those presented in this report.

\section{Blank-Sample Counts}

The total number of blank samples and the number of field blanks collected for groundwater sites differ by analyte group and for constituents within the analyte groups during the 2017-18 sampling period and the cycle 3 sampling period (tables 5.1 and 5.2, respectively). Data for all blank samples from the 2017-18 sampling period are presented in tables 5.11-5.18 of Kingsbury and others (2020). All blank samples collected during the cycle 3 sampling period were analyzed using the corresponding laboratory methods listed in table 2 of Arnold and others (2016a, 2017a, 2018a, 2020b) and Kingsbury and others (2020). Of the 732 VOC blank samples of all types collected during the cycle 3 sampling period (table 5.2), 26 were collected in 2012 or early 2013 and analyzed for an older analytical schedule using purge and trap gas chromatography/mass spectrometry (Gilliom and others, 2006; Zogorski and others, 2006); 706 were collected in 2013-18 and analyzed using the most recent analytical schedule and laboratory methods (purge and trap gas chromatography/mass spectrometry and heated purge and trap gas chromatography/ mass spectrometry). Not included in table 5.1 are sample counts for radiological analytes, for which blank samples were collected starting only in 2018, resulting in only nine field blanks for each analyte. Also not included in table 5.1 are special analytes collected only in selected well networks during the cycle 3 sampling period: arsenic species, perchlorate, and hexavalent chromium (chromium [VI]). In January 2017December 2018, no field blanks were collected for hexavalent chromium, only one was collected for arsenic species, and only two were collected for perchlorate.

Table 5.1. Summary of results for field blanks collected by the National Water-Quality Assessment Project from January 2017 to December 2018.

[DOC, dissolved organic carbon; VOC, volatile organic compound; HHB, human-health benchmark; SMCL, secondary maximum contaminant level]

\begin{tabular}{|c|c|c|c|c|c|}
\hline Type of summary & $\begin{array}{l}\text { Major and } \\
\text { minor } \\
\text { elements }\end{array}$ & $\begin{array}{c}\text { Trace } \\
\text { elements }\end{array}$ & Nutrients and DOC & VOCs & $\begin{array}{l}\text { Microbiological } \\
\text { constituents } 1\end{array}$ \\
\hline Total number of blank samples & 76 & 142 & 66 to 132 & 160 & 44 \\
\hline Number of field blanks & 73 & 72 & 54 to 69 & 61 & 36 \\
\hline Number of constituents analyzed & 10 & 22 & 6 & 85 & 5 \\
\hline $\begin{array}{l}\text { Number of constituents detected in field } \\
\text { blanks }\end{array}$ & 6 & 16 & 5 & 22 & 1 \\
\hline $\begin{array}{l}\text { Number of constituents detected in field } \\
\text { blanks that have an HHB }\end{array}$ & 2 & 14 & 1 & 12 & 0 \\
\hline $\begin{array}{l}\text { Number of constituents detected in field } \\
\text { blanks that have an SMCL }\end{array}$ & 2 & 4 & 0 & 0 & 0 \\
\hline $\begin{array}{l}\text { Largest ratio of the maximum concentra- } \\
\text { tion in a field blank to the corresponding } \\
\text { HHB, in percent }\end{array}$ & 0.35 & 23 & 1.1 & 1.4 & Not applicable \\
\hline
\end{tabular}

1Results for microbiological constituents are for January 2016 to December 2018. 


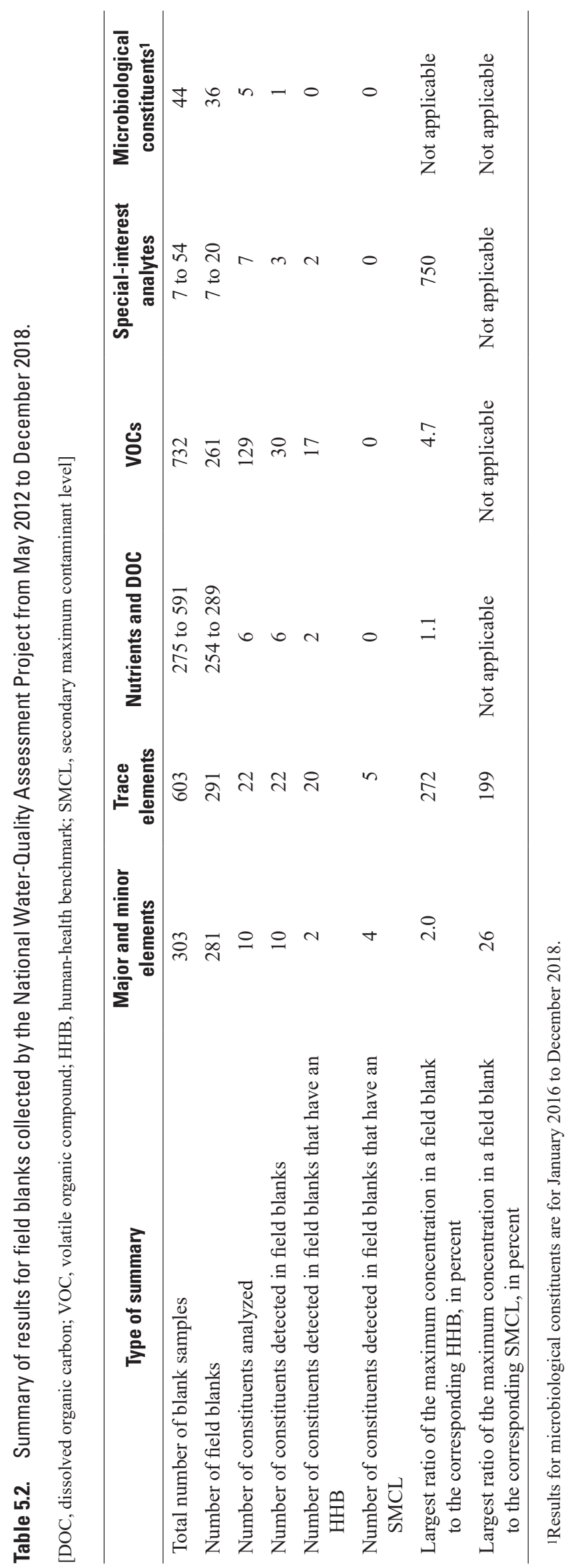




\section{Constituent Concentrations in Blank Samples}

Of the 10 major or minor elements included in laboratory analysis (not including analysis for dissolved-solids concentration), 6 were detected in at least 1 field blank collected in 2017-18 (table 5.1); all 10 elements were detected in at least 1 field blank collected during the cycle 3 sampling period (table 5.2). Two of the major or minor elements detected during the cycle 3 sampling period (fluoride and iron) have HHBs (table 2 of Kingsbury and others, 2020); four (chloride, fluoride, sulfate, and iron) have SMCLs. The maximum concentrations for fluoride and iron in any field blank from the cycle 3 sampling period were each 2.0 percent of their corresponding HHBs. For chloride and sulfate, the maximum concentration in any field blank from the cycle 3 sampling period was less than 1 percent of the corresponding SMCL. For fluoride, the maximum concentration was 3.9 percent of the corresponding SMCL. For iron, the maximum concentration in any field blank from the cycle 3 sampling period was 26 percent of its corresponding SMCL of 300 micrograms per liter $(\mu \mathrm{g} / \mathrm{L})$, reported for an August 2016 sample. Results for blind blanks submitted to the National Water Quality Laboratory (NWQL) to evaluate laboratory data quality indicate a slight high bias for iron during 2016 but no evidence of a laboratory contamination issue (Tedmund Struzeski, U.S. Geological Survey [USGS] Inorganic Blind Sample Project, written commun., 2017 and 2018). Of 280 NAWQA cycle 3 field blanks for iron, the 2 results that exceed 10 percent of the SMCL $(42.0 \mu \mathrm{g} / \mathrm{L}$ and $78.6 \mu \mathrm{g} / \mathrm{L}$ for samples collected in September 2014 and August 2016, respectively) likely reflect isolated events.

Of the 22 trace elements included in laboratory analysis, 16 were detected in at least 1 field blank collected in 2017-18 (table 5.1); all 22 were detected in at least 1 field blank from the cycle 3 sampling period (table 5.2). Of the 22 trace elements detected in field blanks from the cycle 3 sampling period, 20 (aluminum, antimony, arsenic, barium, beryllium, boron, cadmium, chromium, cobalt, copper, lead, manganese, molybdenum, nickel, selenium, silver, strontium, thallium, uranium, and zinc) have HHBs (table 2 of Kingsbury and others, 2020); 5 (aluminum, copper, manganese, silver, and zinc) have SMCLs. For 7 of the 20 detected trace elements with HHBs, the maximum concentration measured in a field blank from the cycle 3 sampling period was less than 1 percent of the corresponding HHB. For nine trace elements (aluminum, antimony, arsenic, beryllium, cadmium, manganese, nickel, thallium, and zinc), the maximum concentration was less than 5 percent of the HHB, and for copper, the maximum concentration was 8.5 percent of the HHB. The maximum concentrations for lead and molybdenum were 15 and 23 percent of their HHBs, respectively, but these likely represent isolated events (with concentrations of $2.3 \mu \mathrm{g} / \mathrm{L}$ in August 2017 for lead and $7.0 \mu \mathrm{g} / \mathrm{L}$ in September 2018 for molybdenum) because all other concentrations were less than 5 percent of the HHB. For cobalt, which was assigned an HHB of $2 \mu \mathrm{g} / \mathrm{L}$ in
2018, concentrations from 10 to 33 percent of the HHB have occurred sporadically for field blanks collected throughout cycle 3 , and a single high concentration of $5.4 \mu \mathrm{g} / \mathrm{L}$ occurred in September 2014. The USGS Office of Water Quality has documented random low-level contamination of water samples with cobalt and manganese from certain capsule filters used by the NAWQA Project and across the USGS from about October 1, 2008, to about September 30, 2014 (USGS Office of Water Quality, written commun., July 1, 2016). Blank samples for cobalt and manganese that were collected for NAWQA during this period were evaluated to determine the possible effects of this contamination on environmental samples, and evaluation results were described in appendix 3 of Arnold and others (2017b). However, one-half of the NAWQA field blanks with cobalt concentrations exceeding 10 percent of the HHB were collected after September 2014 and had no identified source of contamination as of April 2020.

For silver and zinc, the maximum concentration measured in a field blank from the cycle 3 sampling period was less than 1 percent of the corresponding SMCL; for manganese, the maximum concentration was less than 9 percent of the SMCL. For copper, the maximum concentration was 11 percent of the corresponding SMCL of $1,000 \mu \mathrm{g} / \mathrm{L}$, reported for an August 2017 sample; this result likely represents an isolated event because concentrations for all but one other field blank are no more than 5.1 percent of the SMCL. For aluminum, the maximum concentration was nearly 200 percent of the corresponding SMCL of $50 \mu \mathrm{g} / \mathrm{L}$. Results for blind blanks submitted to the NWQL to evaluate laboratory data quality indicate false positive detections of aluminum in blank samples submitted to the laboratory during July and August 2014, August-December 2015, and June 2016 (U.S. Geological Survey, 2020). Investigation of this issue by the NWQL indicated the occurrence of sporadic contamination at concentrations of as much as $63 \mu \mathrm{g} / \mathrm{L}$ from at least July 2014 through December 2015, although the source of contamination and, therefore, the exact magnitude of contamination and the period(s) affected were not established (Tedmund Struzeski, USGS Inorganic Blind Sample Project, written commun., 2015). For NAWQA field blanks collected through the end of December 2018, reported detections of aluminum greater than the laboratory reporting limit occurred in blank samples collected primarily between May 29, 2014, and July 16, 2014; between March 25, 2015, and September 8, 2015; and between April 7, 2016, and August 10, 2016.

Of the five nutrients or groups of nutrients that the laboratory analyzes directly (as opposed to the nutrients with calculated results), four were detected in at least one field blank collected in 2017-18, as was DOC (table 5.1). All five nutrients and DOC were detected in at least one field blank from the cycle 3 sampling period (table 5.2). Two of the nutrients detected in field blanks from the cycle 3 sampling period (nitrite and nitrate) have HHBs (table 2 of Kingsbury and others, 2020); none have SMCLs. For each of the two nutrients with $\mathrm{HHBs}$, the maximum concentration measured in a field blank from the cycle 3 sampling period was no more 
than 1.1 percent of the corresponding threshold. DOC does not have an HHB but was detected in 23 of 54 field blanks collected during $2017-18$ and in 85 of 254 field blanks collected during cycle 3 . Concentrations during cycle 3 ranged from 0.23 to 633 milligrams per liter $(\mathrm{mg} / \mathrm{L})$ and included multiple values greater than $1 \mathrm{mg} / \mathrm{L}$; however, concentrations of this magnitude probably reflect inadequate rinsing of sampling equipment with blank water between use of methanol during the cleaning process and subsequent collection of the blank sample. Therefore, these results likely are not representative of the actual potential for contamination of environmental samples, which are collected only after flushing of sampling equipment with copious quantities of native groundwater.

Blank samples collected in 2012 were analyzed for 85 VOCs, and blank samples collected in 2013 through 2018 were analyzed for a different (but partially overlapping) list of 85 VOCs; the change in laboratory methods and constituent lists resulted in a total of 129 VOCs being included in the overall dataset of blank results. In total, 22 VOCs were detected in at least 1 field blank collected in 2017-18 (table 5.1), and 30 VOCs were detected in at least 1 field blank from the cycle 3 sampling period (table 5.2). A total of 17 compounds detected in field blanks from the cycle 3 sampling period (1,1-dichloroethene, 1,2-dibromo3-chloropropane, 1,2,4-trimethylbenzene, 1,4-dichlorobenzene, benzene, carbon disulfide, cyclohexanone, dichloromethane, ethyl acetate, ethylbenzene, isopropyl alcohol, $m$-xylene plus $p$-xylene, $o$-xylene, styrene, toluene, trichloroethene, and trichloromethane) have HHBs (table 2 of Kingsbury and others, 2020) and none have SMCLs. For 12 of the 17 VOCs with HHBs, the maximum concentration measured in a blank was less than 1 percent of the corresponding HHB threshold; for the remaining 5 VOCs (1,1-dichloroethene, 1,2-dibromo3 -chloropropane, dichloromethane, isopropyl alcohol, and trichloroethene), the maximum concentration was less than 5 percent of the corresponding HHB threshold. Some detections of toluene in field blanks might be the consequence of the presence of toluene in vials used for sample collection; testing of vials has indicated concentrations of as much as about $0.16 \mu \mathrm{g} / \mathrm{L}$ (Jeff McCoy, USGS NWQL, written commun., August 15,2018), which is several orders of magnitude less than the maximum contaminant level.

A few radiological analytes were detected in one or more of the nine field blanks from the cycle 3 sampling period. In two field blanks, alpha radioactivity (30-day count), alpha radioactivity (72-hour count), and polonium-210 each had detections; in one field blank, beta radioactivity (30-day count) and beta radioactivity (72-hour count) each had detections. There were no detections for lead-210 or radium isotopes. Maximum values for the alpha and beta radioactivity analytes were 7 percent or less of their corresponding HHBs; polonium-210 does not have an HHB.

A few of the special analytes collected in only selected well networks were detected in one or more field blanks from the cycle 3 sampling period. The one field blank collected in 2017-18 for arsenic speciation had no detections. Seven field blanks were collected for arsenic speciation during the cycle 3 sampling period. In these 7 field blanks, there were no detections of 3 arsenic species (arsenite, dimethylarsinate, and monomethylarsonate), but arsenate was detected in 1 field blank at a concentration of $1.51 \mu \mathrm{g} / \mathrm{L}$, which is about 15 percent of the HHB of $10 \mu \mathrm{g} / \mathrm{L}$ for total arsenic. Because it is possible that contamination could limit the suitability of arsenate results for comparison to the arsenic HHB, total arsenic results by NWQL laboratory schedule 2710 , which are available for all samples that have arsenate results, should be used for comparison to the HHB. Perchlorate was not detected in either of the 2 field blanks collected during 2017-18 or in any of the 19 total field blanks collected during the cycle 3 sampling period. No hexavalent chromium field blanks were collected during 2017-18, but hexavalent chromium was detected in 2 of the 20 field blanks from the cycle 3 sampling period at $0.2 \mu \mathrm{g} / \mathrm{L}$ (in June 2015) and $0.3 \mu \mathrm{g} / \mathrm{L}$ (in July 2014), the latter of which is 750 percent of the upper cancer HBSL of $0.04 \mu \mathrm{g} / \mathrm{L}$ (which is less than the laboratory reporting level), but only 7.5 percent of the lower cancer HBSL of $4 \mu \mathrm{g} / \mathrm{L}$ and 1.5 percent of the noncancer HBSL of $20 \mu \mathrm{g} / \mathrm{L}$. Corresponding total chromium values typically are reported by the same USGS Trace Metal Laboratory in Boulder, Colorado, that analyzes for hexavalent chromium. Of the 19 samples from the cycle 3 sampling period that had total chromium results reported by this laboratory, 2 field blanks had a detection of total chromium at concentrations of as much as $0.6 \mu \mathrm{g} / \mathrm{L}$, which is 0.6 percent of the HHB of $100 \mu \mathrm{g} / \mathrm{L}$. Therefore, it seems that there is minimal potential for contamination of total chromium from the USGS Trace Metal Laboratory to affect comparison of these values to HHBs.

Blank samples were collected in 2016-18 for five microbiological constituents, which include the concentrations of three fecal-indicator bacteria and the presence of two coliphage viruses. None of the 36 field blanks collected during this period had detections of fecal-indicator bacteria. Of 36 field blanks, 1 indicated the presence of F-specific coliphage, and none indicated the presence of somatic coliphage. Currently, there are no HHBs related to the occurrence of coliphage.

The maximum concentrations of nutrients and VOCs in field blanks from the cycle 3 sampling period are all substantially less than the thresholds used by the NAWQA Project to distinguish between low and moderate concentrations (50 percent of the HHB or SMCL for inorganic constituents and 10 percent of the HHB for organic constituents); therefore, results of the field-blank samples for these constituent groups indicate minimal potential for effects of contamination on the number of groundwater samples that would be classified as having moderate or high concentrations relative to current HHBs or SMCLs. This same conclusion was reached for pesticide compounds by Bexfield and others (2020). For most major, minor, and trace elements, the maximum concentrations in field blanks from the cycle 3 sampling period also are substantially less than the relevant thresholds. Concentrations exceeded 20 percent of the HHB for one field 
blank for molybdenum and exceeded 20 percent of the SMCL for two field blanks for iron, but there do not seem to be any systematic contamination issues that would substantially affect classification of results for these constituents relative to the thresholds (for iron, comparisons to its HHB are largely unaffected because the maximum field-blank concentration is only 2 percent of the HHB). Because data from blind blanks and field blanks indicate that laboratory contamination might have affected aluminum results considerably for some environmental samples from late May 2014 through at least August 2016, aluminum results from this period cannot positively be classified as moderate or high relative to the SMCL of $50 \mu \mathrm{g} / \mathrm{L}$; classifications relative to its much higher HHB of $6,000 \mu \mathrm{g} / \mathrm{L}$ are not affected. For cobalt, based on the sporadic occurrence of concentrations from 10 to 33 percent of the HHB throughout cycle 3 , and a single high concentration of $5.4 \mu \mathrm{g} / \mathrm{L}$, classifications relative to the HHB of $2 \mu \mathrm{g} / \mathrm{L}$ in 2018 cannot be made with high confidence. Finally, hexavalent chromium also cannot positively be classified as moderate or high relative to its lower cancer HBSL because of a laboratory reporting level and field-blank concentrations greater than this threshold, but comparisons to its higher HHBs are not affected. Detections of radiological analytes in the relatively small number of available field blanks are substantially less than the relevant thresholds.

\section{Replicate Sample Approach}

Replicate samples are QC samples that are used to estimate variability of analytical results caused by random measurement error (Mueller and others, 2015). Replicate samples are two or more water samples that are collected, processed, and analyzed in a manner that allows them to be considered identical in composition and analysis (Mueller and others, 2015). Replicate groundwater samples for NAWQA consist of two samples collected one after the other in the field (sequential field replicates).

Replicate samples typically are used to evaluate variability in analyte concentration by estimating standard deviation (SD) as a function of concentration (Mueller and others, 2015). The presence of censored values affects the calculation of these estimates and generally necessitates estimation of the variability in analyte detection as well. One measure of the variability in analyte detection is the mean detection rate for all replicate pairs having at least one detection (Martin, 2002; Mueller and others, 2015). Another measure is the percentage of replicate sets with inconsistent detections, which is calculated as the number of replicate sets with inconsistent detections divided by the total number of replicate sets minus the number of sets with consistent nondetections (Martin, 2002; Mueller and others, 2015). A one-sided upper confidence limit for the percentage of inconsistent replicate sets can be calculated as described by Mueller and others (2015). Multiple approaches are available to estimate the variability of analyte concentrations as a function of concentration. Three of these approaches and the requirements to apply them are described by Mueller and others (2015).
Data and results of the initial evaluation of data from replicate samples for a variety of analytes collected during the cycle 3 sampling period of May 2012 through December 2018 are presented in this appendix. Pesticide compounds are not included here because Bexfield and others (2020) present an evaluation of pesticide replicate samples collected for the NAWQA Project in May 2013 to September 2018. The objective of this initial evaluation of replicate samples was to broadly characterize variability in analyte detection and concentration to explore implications for comparisons of environmental concentrations of analytes as reported by the relevant laboratories with their corresponding HHBs or SMCLs. For example, large variability in analyte detection and (or) concentration near an HHB could reduce confidence in whether or not the reported concentration represents a true exceedance of an HHB in the environment. As part of this evaluation, for analytes that include censored values and have at least 10 replicate pairs not composed of consistent nondetections, the mean detection rate (for all replicate pairs having at least one detection) and the percentage of replicate sets with inconsistent detections were calculated. A piecewise-linear model used by Mueller and Titus (2005) and described by Mueller and others (2015) was used to estimate variability in concentrations for analytes having at least 10 replicate pairs with consistent detections. This two-range model divides concentrations into (1) a low range for which the SD of replicates generally is uniform and the mean SD is used to estimate variability and (2) a high range for which the relative standard deviation (RSD; the ratio, in percent, of SD to mean concentration) generally is uniform and the mean RSD is used to estimate variability. Graphs of SD and RSD against mean concentration are used to select an appropriate boundary concentration between the low and high ranges (Mueller and others, 2015). In some cases, either SD or RSD is uniform throughout the range of available concentrations and, therefore, no boundary is needed.

\section{Replicate Sample Counts}

The total number of replicate samples collected for groundwater sites during cycle 3 varies by analyte group and for constituents within the analyte groups (table 5.3). Data for all replicate samples for the January 2017 through December 2018 sampling period are presented in tables 5.11-5.20 of Kingsbury and others (2020). All cycle 3 replicate samples were analyzed using the corresponding laboratory methods listed in table 2 of Kingsbury and others (2020). Of the 142 cycle 3 VOC replicate samples, 5 were collected in 2012 and analyzed for an older analytical schedule using purge and trap gas chromatography/mass spectrometry (Gilliom and others, 2006; Zogorski and others, 2006). The remaining 137 were collected in 2013-18 and analyzed using the most recent analytical schedule and laboratory methods (purge and trap gas chromatography/mass spectrometry and heated purge and trap gas chromatography/mass spectrometry). 


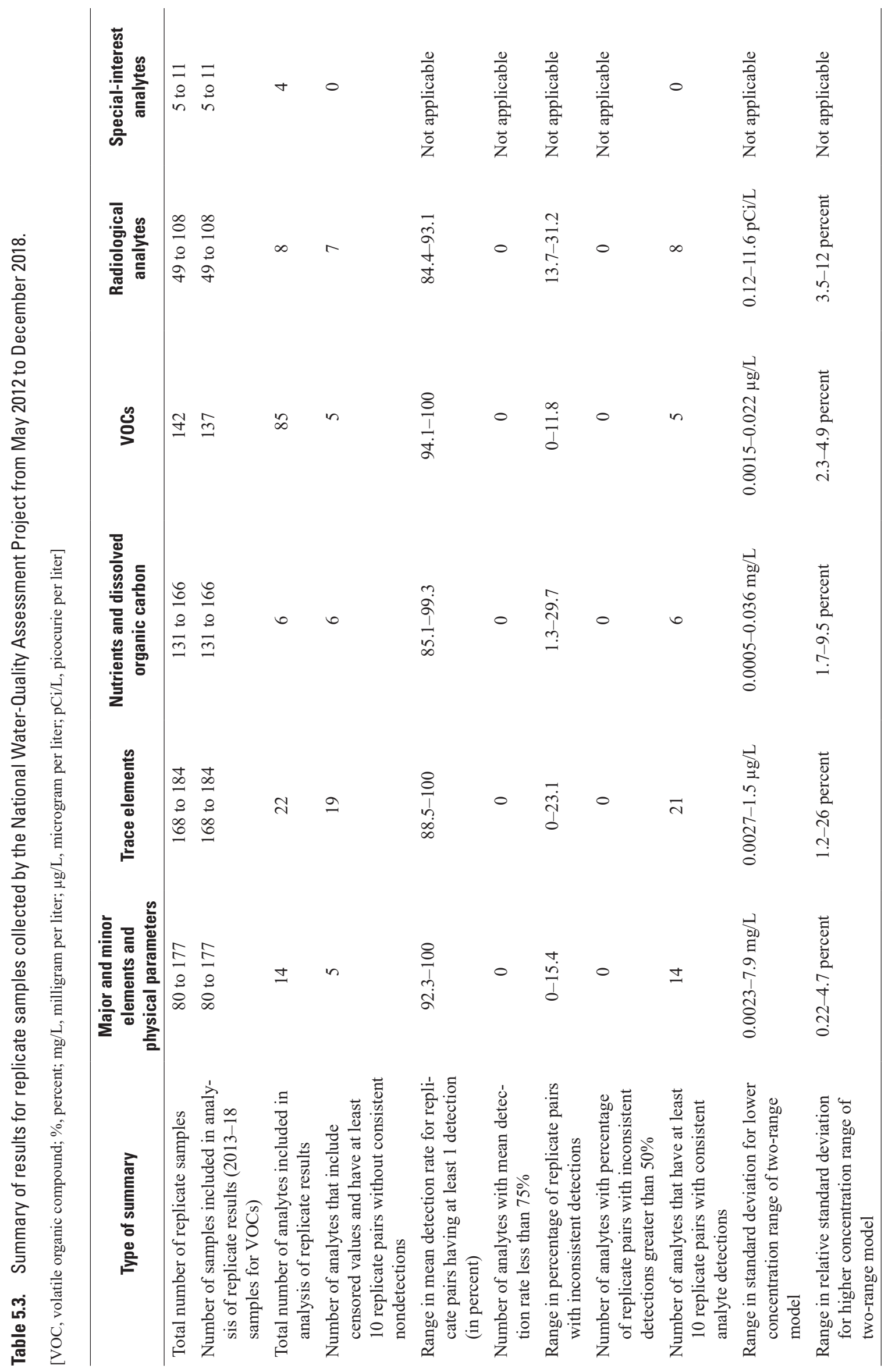




\section{Replicate Sample Results}

Analysis of variability in analyte detection and (or) analyte concentration was attempted for only the subset of analytes that met certain requirements. Analysis of replicate results was not attempted for analyte/method combinations for which fewer than 10 replicate pairs had been analyzed; therefore, VOCs determined with older laboratory methods used for analysis of replicates collected in 2012 were not evaluated for variability. In addition, analysis of variability in analyte detection was completed only for analytes that included censored values and had at least 10 replicate pairs without consistent nondetections (table 5.4). Analysis of analyte concentrations was completed only for analytes that had at least 10 replicate pairs with consistent detections (table 5.5).

Among all constituents for which variability in detection was estimated, the mean detection rate ranged from 84.4 to 100 percent, and the percentage of pairs with inconsistent detections ranged from 0 to 31.2 percent (table 5.4). In his assessment of pesticides, Martin (2002) used a mean detection rate of 75 percent or less or a percentage of inconsistent replicate sets of 50 percent or more to indicate high variability of detection. Using those same criteria, none of the constituents analyzed for this study would be considered to have high variability of detection. Martin (2002) also used a mean detection rate of 90 percent or more or a percentage of inconsistent replicate sets of 25 percent or less to indicate low variability of detection. Under these criteria, the nutrient nitrite and the radiological analytes alpha radioactivity (30-day count), radium-226, and radium-228 do not have low variability of detection but would be considered to have moderate variability. The initial analysis of variability of detection presented here did not include calculation of an upper confidence bound on percentages of inconsistent replicate sets to quantify uncertainty and did not account for changes in variability across concentration ranges. In general, variability of detection is higher at low concentrations and decreases with increasing concentrations (Martin, 2002). More detailed analysis of this type might be needed for the interpretation of environmental concentrations for objectives other than those presented in this report.

For all constituents for which variability in concentration was estimated, the mean SD and (or) RSD determined for specified concentration ranges by means of the two-range model are presented in table 5.5. For major and minor elements and physical parameters, the mean SD at lower or all available concentrations was $0.2 \mathrm{mg} / \mathrm{L}$ or less, except for alkalinity and residue on evaporation (dissolved solids), and the mean RSD at higher concentrations was less than 3.0 percent, except for bromide and iron. For trace elements, the mean SD at lower or all available concentrations was less than $0.3 \mu \mathrm{g} / \mathrm{L}$, except for aluminum and zinc, and the mean RSD at higher concentrations was 6.5 percent or less, except for copper and lead. For nutrients and dissolved organic carbon, the mean SD at lower concentrations was less than $0.04 \mathrm{mg} / \mathrm{L}$, and the mean RSD at higher concentrations was less than 3 percent, except for dissolved organic carbon. For VOCs, only 5 compounds had at least 10 replicate pairs with consistent detections. Mean SDs were calculated for lower concentration ranges for four compounds, and all were $0.022 \mu \mathrm{g} / \mathrm{L}$ or less; only two compounds had enough data to calculate a mean RSD for the upper concentration range, and both values were less than 5 percent. For radiological analytes, the mean SD at lower concentrations was 0.77 picocurie per liter or less, except for radon, and the mean RSD at higher concentrations was 10 percent or less, with the exception of alpha radioactivity (72-hour count).

None of the special-interest analytes collected in only selected well networks had at least 10 replicate pairs without consistent nondetections for a rigorous evaluation of variability. However, the available replicate pairs without consistent nondetections for arsenate (nine pairs) and arsenite (eight pairs) all had detections in both samples of the pair, and the detected concentrations were similar. Dimethylarsinate and monomethylarsenate were not detected in either sample of 10 replicate pairs. Out of 11 sample pairs, perchlorate was not detected in either sample of 3 pairs, was detected in 1 sample of a single pair (at a concentration nearly equivalent to the laboratory reporting level), and was detected in both samples of 7 pairs (at similar concentrations). Out of nine sample pairs, hexavalent chromium was not detected in either sample of three pairs, and had inconsistent detections in three of the six other pairs; concentrations within the three pairs with consistent detections were similar. Out of eight sample pairs for total chromium from the Boulder, Colo., laboratory, chromium was not detected in either sample of two pairs, was detected in one sample of two pairs, and was detected in both samples of four pairs (two of which had similar concentrations between samples). Five replicate samples were analyzed for strontium isotope ratios, for which a nondetection is not a possible result; the isotope ratios within all five sample pairs were identical.

Overall, the available results indicate generally low variability in analyte detection and concentration, meaning that random measurement error has minimal potential to affect the number of groundwater samples that would be classified as having moderate or high concentrations relative to current HHBs or SMCLs. However, further analysis beyond the scope of this initial evaluation of replicate results, such as the calculation of confidence intervals, would be needed to quantify the likely effects of variability for use of the environmental data for specific purposes. 
Table 5.4. Estimated variability in detection of selected analytes based on field replicate samples collected by the U.S. Geological Survey National Water-Quality Assessment Project, May 2012 through December 2018.

[Variability was evaluated only for constituents having censored values and at least 10 replicate pairs without consistent nondetections. N, number of pairs with at least one detection]

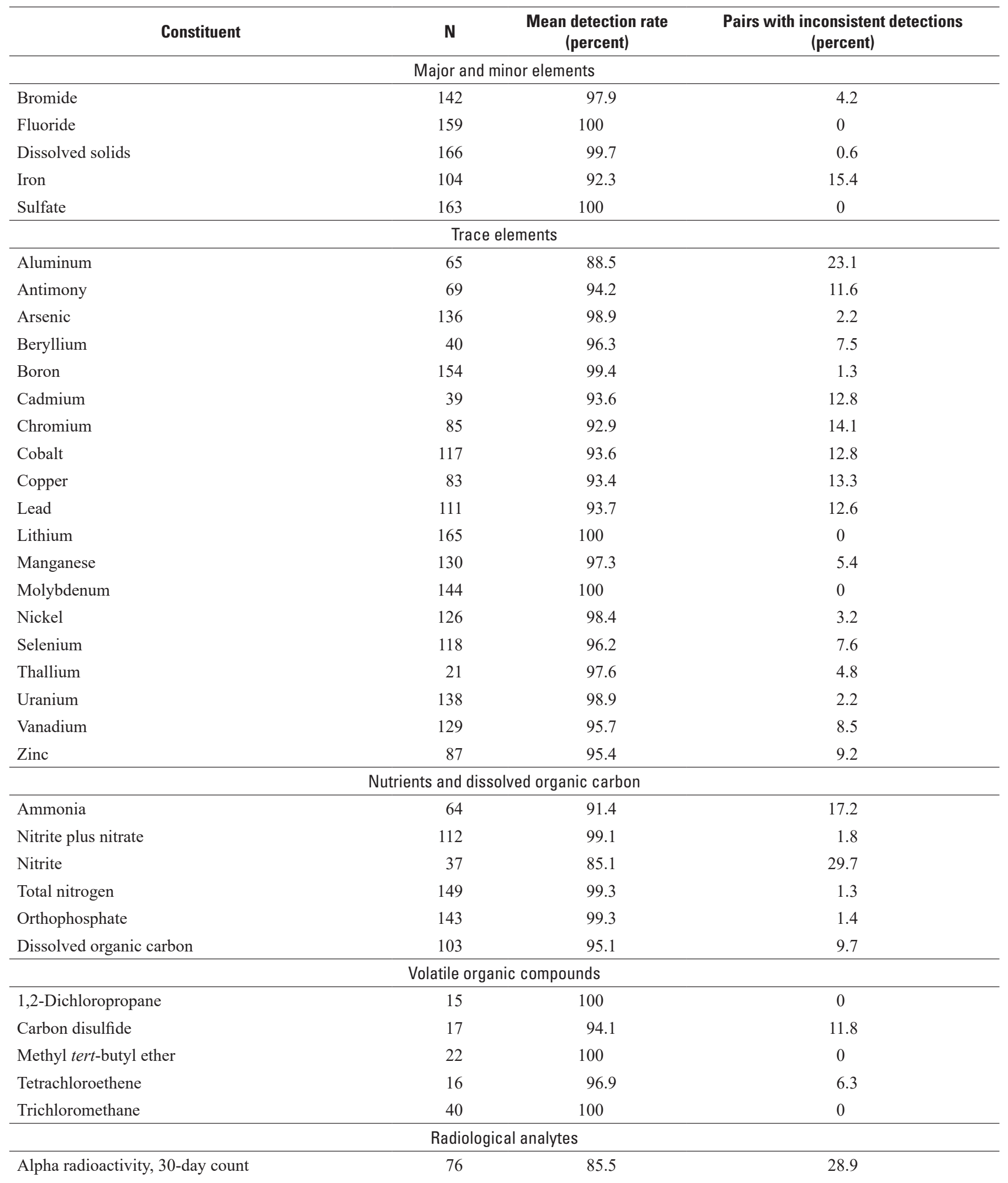


Table 5.4. Estimated variability in detection of selected analytes based on field replicate samples collected by the U.S. Geological Survey National Water-Quality Assessment Project, May 2012 through December 2018.-Continued

[Variability was evaluated only for constituents having censored values and at least 10 replicate pairs without consistent nondetections. N, number of pairs with at least one detection]

\begin{tabular}{lccc}
\hline \multicolumn{1}{c}{ Constituent } & N & $\begin{array}{c}\text { Mean detection rate } \\
\text { (percent) }\end{array}$ & $\begin{array}{c}\text { Pairs with inconsistent detections } \\
\text { (percent) }\end{array}$ \\
\hline Alpha radioactivity, 72-hour count & Radiological analytes-Continued & \\
Beta radioactivity, 30-day count & 90 & 88.3 & 23.3 \\
Beta radioactivity, 72-hour count & 100 & 93.0 & 14.0 \\
Radium-224 & 102 & 93.1 & 13.7 \\
Radium-226 & 78 & 91.7 & 16.7 \\
Radium-228 & 100 & 84.5 & 31.0 \\
\hline
\end{tabular}

\section{Spike Sample Approach}

Spike samples are QC samples that are used to estimate any positive or negative bias that might result from method performance, effects of the sample matrix, and (or) analyte degradation during sample shipment and storage (Mueller and others, 2015). Spike samples are collected by fortifying (spiking) a water sample with known concentrations of analytes. For VOCs, trace elements, and microbiological constituents, NAWQA collects laboratory matrix spikes, meaning that the spike solution is added to an environmental sample at the laboratory. For pesticide compounds and arsenic species, NAWQA collects field matrix spikes, meaning that the spike solution is added to an environmental sample in the field. Both types of spikes estimate recovery bias in an environmental water sample that could be caused by a problem with performance of the laboratory method and (or) by the chemical, physical, or biological characteristics of the water (Mueller and others, 2015). Field matrix spikes also reflect any degradation that might have occurred in an analyte during the period between sample collection and laboratory analysis. Evaluations of recoveries for laboratory matrix spikes for VOCs and trace elements and field matrix spikes for arsenic species are included in this report, but an evaluation of recoveries for field matrix spikes for pesticides is not included here because Bexfield and others (2020) present this type of evaluation for pesticide spike samples collected for the NAWQA Project in May 2013 to September 2018. Microbiological constituents are discussed in terms of whether or not the spiked constituent was determined to be present in the sample during analysis.

The percentage recovery of an analyte in an individual spike sample is calculated by subtracting the concentration of the paired unspiked sample (collected closely in time) from the concentration of the spiked sample, then dividing by the expected concentration (and by the dilution factor, if applicable) and multiplying by 100 . The expected concentration is equal to the concentration of the spike solution times the volume of spike solution added to the sample, divided by the volume of the sample that was spiked. When the laboratory reported that an analyte was not detected in the paired unspiked sample, a concentration of zero was assumed for the purposes of calculating the percentage recovery. For all analytes except microbiological constituents, spike solutions were obtained through the NWQL, which provides the concentration of each analyte included in an individual spike lot. Analytes included in spike solutions were assumed not to have degraded before use of the spike solution, although it is possible that future evaluation of spike sample results might indicate that the assumption is violated for certain spike lots and (or) compounds. For VOCs, the NWQL was assumed to have added 20 microliters of spike solution to a 43-milliliter sample. For trace elements, the NWQL was assumed to have added 6 microliters of spike solution to a 6-milliliter sample. For arsenic species, field crews were assumed to have added 100 microliters of spike solution to an 11.5-milliliter sample. Samples were excluded from analysis of recoveries when there was evidence that they had been collected after chlorination, which can affect the analysis of many compounds. Individual results were excluded from analysis of recoveries when the concentration present for the compound in the unspiked sample exceeded the expected spike concentration because this can result in increased uncertainty in recovery (Shoda and others, 2018). Individual results also were excluded when the spiked concentration was less than the maximum laboratory reporting level for the constituent or when the result was affected by dilution of the sample at the laboratory.

Results of an initial evaluation of recovery data from laboratory matrix spikes for VOCs analyzed under laboratory schedules 4436 (S4436) and 4437 (S4437), from laboratory matrix spikes for trace elements analyzed under laboratory schedule 2710 (S2710), and from field matrix spikes for arsenic species analyzed under laboratory code 3142 (LC3142) during the cycle 3 sampling period are presented in this report (laboratory schedules and codes are listed in table 2 of Kingsbury and others [2020]). An evaluation of presence/absence results for spikes analyzed for microbiological constituents in 2016-18 also is presented. Data for laboratory matrix spikes collected for VOCs and trace elements and field matrix spikes collected for arsenic species in January 2017December 2018 are published in this report, as are data for 
Table 5.5. Estimated variability in concentrations of selected analytes based on field replicate samples collected by the U.S. Geological Survey National Water-Quality Assessment Project, May 2012 through December 2018.

[Variability was evaluated only for constituents having at least 10 replicate pairs with consistent detections. N, number of values in that category; mg/L, milligram per liter; IPT, inflection point titration method; $\mathrm{CaCO}_{3}$, calcium carbonate; SD, standard deviation; $\mu \mathrm{S} / \mathrm{cm}$, microsiemens per centimeter at 25 degrees Celsius; RSD, relative standard deviation; <, less than; >, greater than; $\mu \mathrm{g} / \mathrm{L}$, microgram per liter; $\mathrm{pCi} / \mathrm{L}$, picocurie per liter; $\geq$, greater than or equal to]

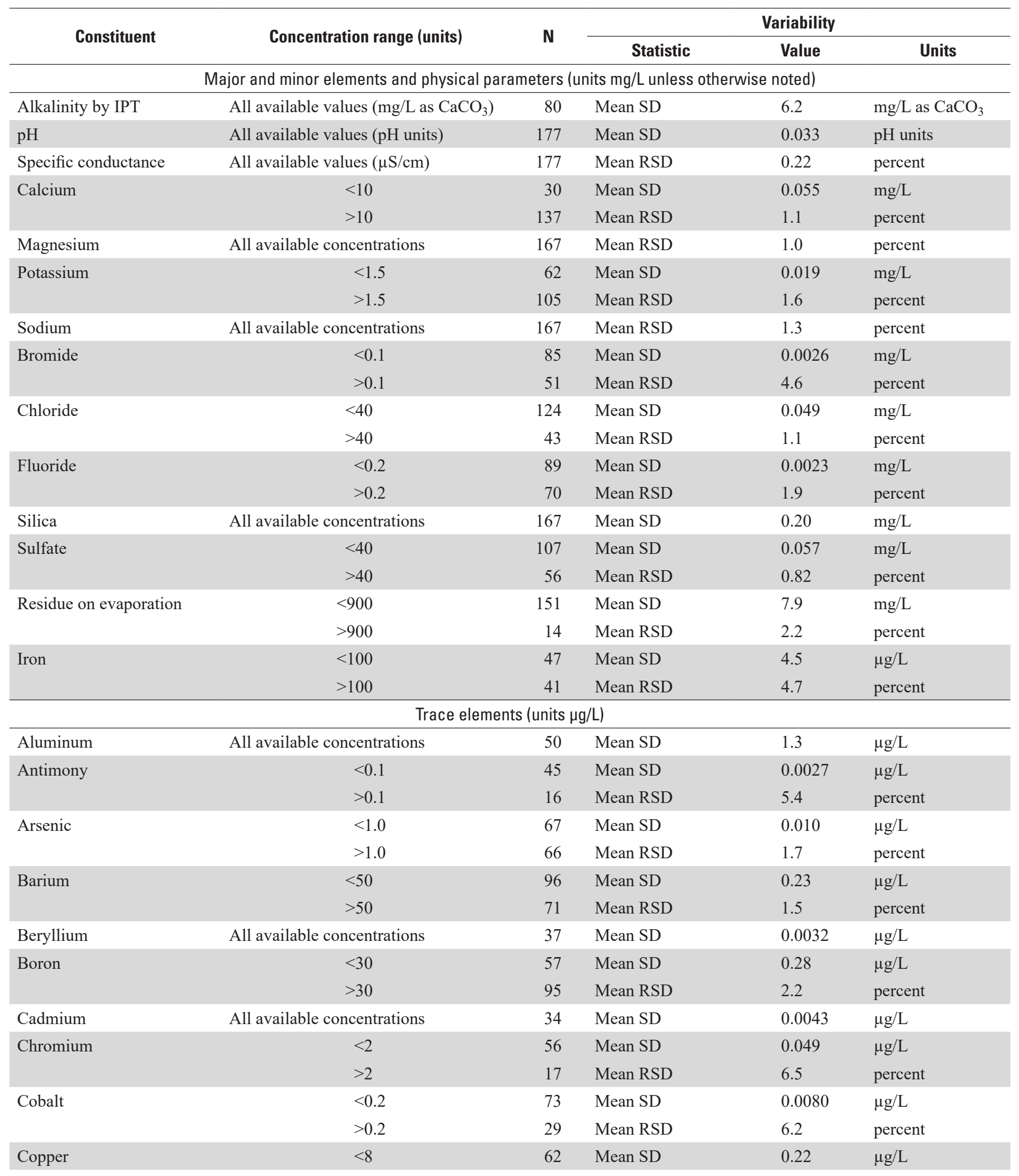


Table 5.5. Estimated variability in concentrations of selected analytes based on field replicate samples collected by the U.S. Geological Survey National Water-Quality Assessment Project, May 2012 through December 2018. - Continued

[Variability was evaluated only for constituents having at least 10 replicate pairs with consistent detections. N, number of values in that category; mg/L, milligram per liter; IPT, inflection point titration method; $\mathrm{CaCO}_{3}$, calcium carbonate; SD, standard deviation; $\mu \mathrm{S} / \mathrm{cm}$, microsiemens per centimeter at 25 degrees Celsius; RSD, relative standard deviation; <, less than; >, greater than; $\mu \mathrm{g} / \mathrm{L}$, microgram per liter; $\mathrm{pCi} / \mathrm{L}$, picocurie per liter; $\geq$, greater than or equal to]

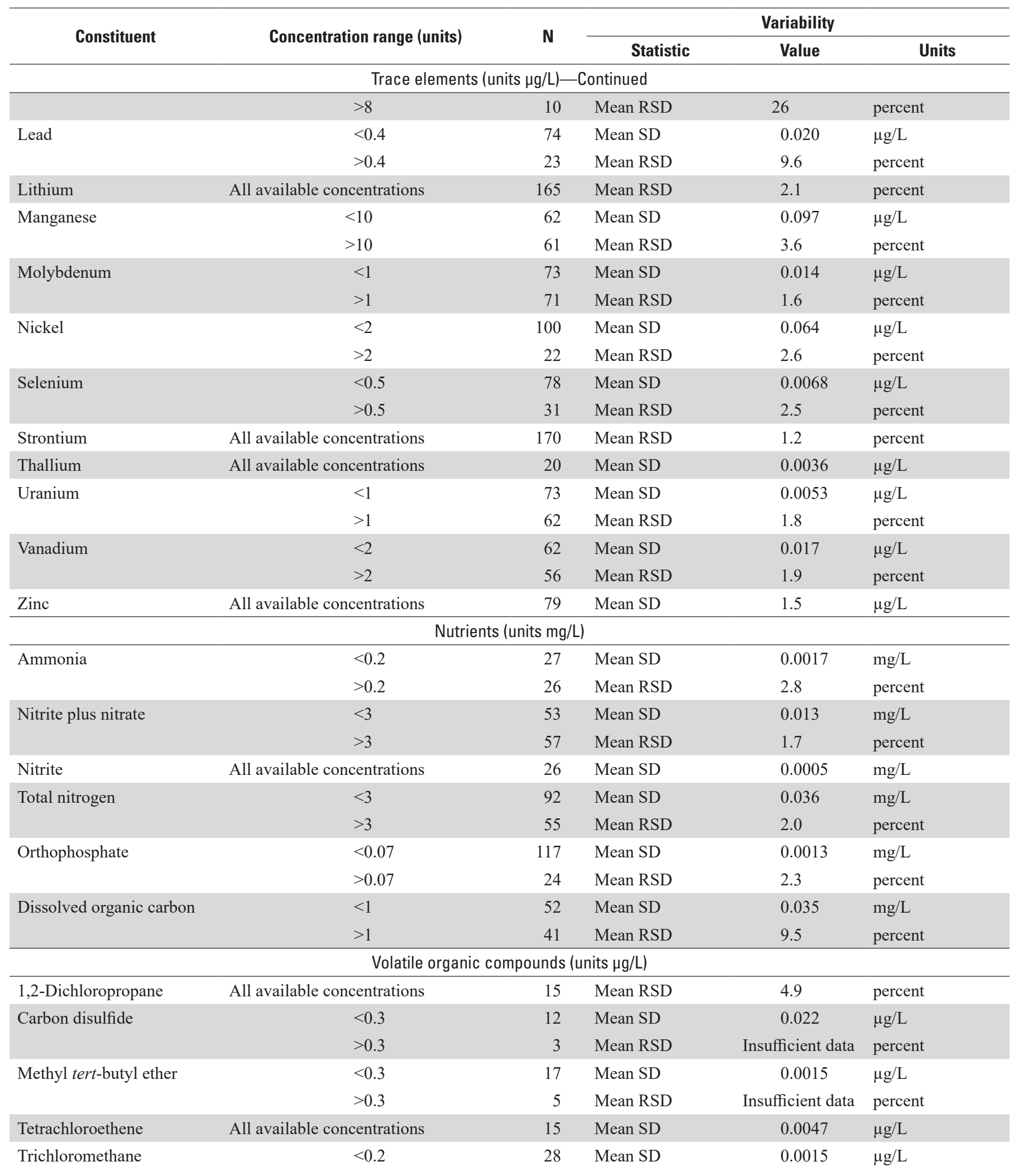


Table 5.5. Estimated variability in concentrations of selected analytes based on field replicate samples collected by the U.S. Geological Survey National Water-Quality Assessment Project, May 2012 through December 2018.—Continued

[Variability was evaluated only for constituents having at least 10 replicate pairs with consistent detections. N, number of values in that category; mg/L, milligram per liter; IPT, inflection point titration method; $\mathrm{CaCO}_{3}$, calcium carbonate; SD, standard deviation; $\mu \mathrm{S} / \mathrm{cm}$, microsiemens per centimeter at 25 degrees Celsius; RSD, relative standard deviation; <, less than; >, greater than; $\mu \mathrm{g} / \mathrm{L}$, microgram per liter; $\mathrm{pCi} / \mathrm{L}$, picocurie per liter; $\geq$, greater than or equal to]

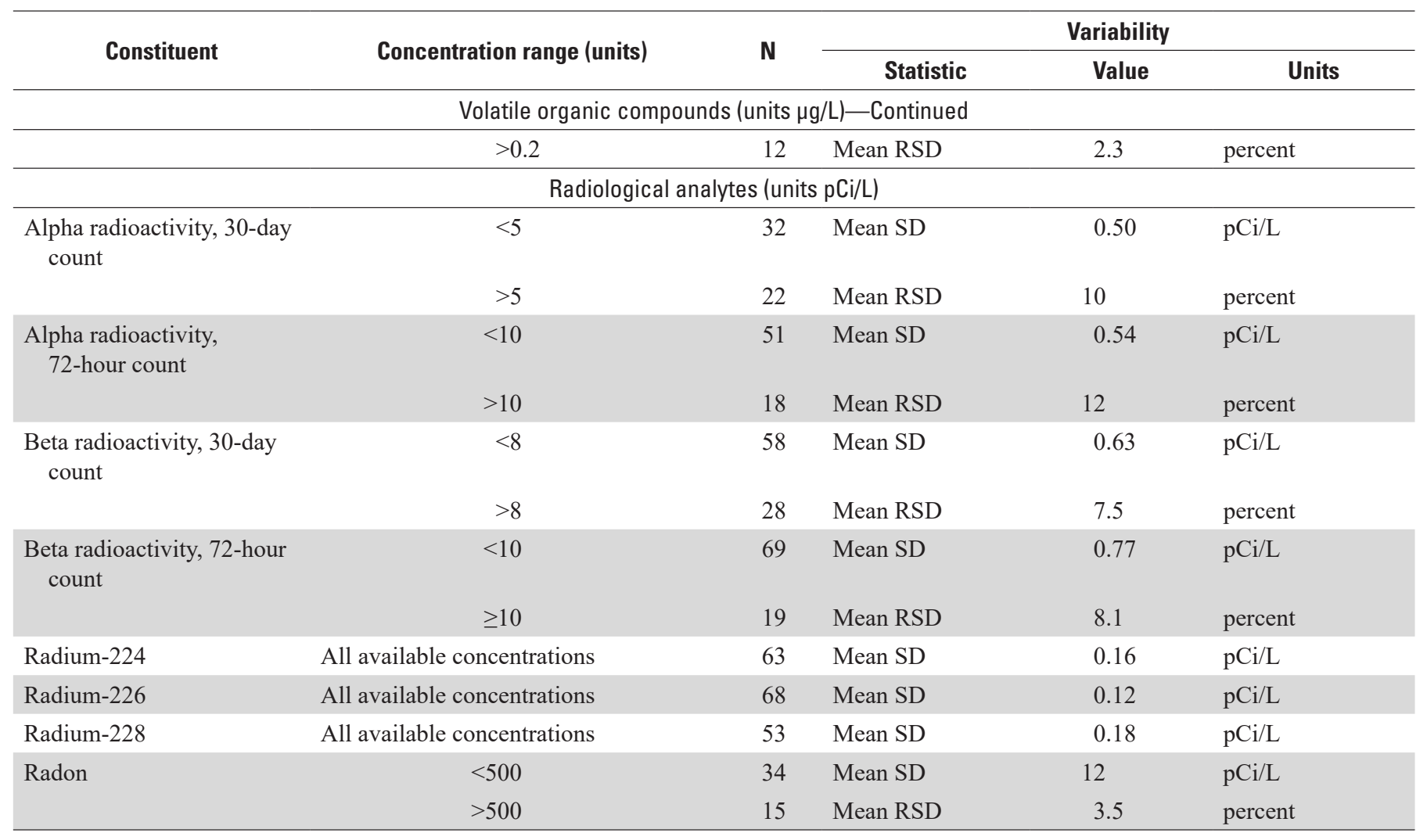

laboratory matrix spikes collected for microbiological constituents in January 2016-December 2018. Data and results of earlier evaluations of recovery data from laboratory matrix spikes collected for VOCs in 2012 under older laboratory schedules 2020 and 4024 and from laboratory matrix spikes collected for VOCs collected in May 2013 through December 2014 for S4436 and S4437 are presented in Arnold and others (2017a, b); data and results of an earlier evaluation of recovery data for field matrix spikes collected for arsenic speciation in 2014 also are presented there. Data for VOC and arsenic speciation spikes collected in January 2015 through December 2016, and an evaluation of VOC and arsenic speciation spike results for cycle 3 up until December 2016, are presented in Arnold and others (2020a, b). Data for laboratory matrix spikes for trace elements only began to be collected in 2017.

The objective of completing an initial evaluation of spike samples was to determine if substantial positive or negative recovery bias exists for any analytes. Substantial positive or negative bias could have implications for comparisons of environmental concentrations of these analytes as reported by the laboratory with their corresponding HHBs. For example, a large negative recovery bias could result in the laboratory reporting a concentration that is substantially less than the concentration actually present in the environment, leading to an incorrect conclusion that the concentration in the environment does not exceed an HHB when it actually does. For the purposes of this initial evaluation of spike samples, a median recovery between 70 and 130 percent is considered acceptable. Further evaluation of results for spike samples would be needed to determine if recovery bias for certain analytes would affect the interpretation of environmental concentrations of those analytes for objectives other than those presented in this report.

\section{Spike Sample Counts}

Between May 2013 and December 2018, a total of 135 laboratory matrix spikes for VOCs by S4436, 138 laboratory matrix spikes for VOCs by S4437, 29 laboratory matrix spikes for trace elements by S2710 (including samples with results that could be adjusted appropriately for dilution when needed), 25 laboratory matrix spikes for microbiological constituents (coliphage presence/absence only), and 12 field matrix spikes for arsenic species were collected for the NAWQA Project (tables 5.6-5.10). Data for VOC, trace element, and arsenic 
species samples from January 2017 through December 2018 are presented in tables 5.13,5.14, and 5.16 of Kingsbury and others (2020), and data for microbiological samples from January 2016 through December 2018 are presented in table 5.15.

\section{Spike Sample Results}

For VOC laboratory matrix spikes collected during cycle 3 for analysis by S4436 or S4437, the median recovery for the 85 individual compounds analyzed (methyl tert-butyl ether is included on both laboratory schedules) ranged from 72.6 to 110.9 percent, and most values were between about 90 and 110 percent (tables 5.6-5.8; table 5.14 of Kingsbury and others [2020]; figs. 5.1 and 5.2), indicating that bias from method performance or effects of the sample matrix generally is relatively small. Therefore, laboratory matrix spike recovery results do not indicate any issues with comparing reported VOC concentrations to their corresponding HHBs.

For the 29 laboratory matrix spikes collected during cycle 3 for analysis by S2710, the median recovery for individual constituents ranged from 82.4 percent for thallium to 111.2 percent for molybdenum (tables 5.6 and 5.9; table 5.13 of Kingsbury and others [2020]; fig. 5.3), indicating that bias from method performance or effects of the sample matrix generally is small. Therefore, laboratory matrix spike recovery results do not indicate any substantial issues with comparing reported trace-element concentrations to their corresponding HHBs.

The 25 laboratory matrix spikes collected in January 2016 through December 2018 for microbiological indicators were analyzed for the presence of F-specific and somatic coliphage, and detections of these constituents were confirmed in all 25 samples (table 5.6; table 5.15 of Kingsbury and others [2020]), indicating no negative bias from method performance or effects of the sample matrix. No HHBs exist for these constituents.

For the 12 arsenic speciation field matrix spikes collected during cycle 3 for analysis by LC3142, median recoveries ranged from 86.5 percent for monomethylarsonate to 91.3 percent for arsenite (tables 5.6 and 5.10; table 5.16 of Kingsbury and others [2020]; fig. 5.4), indicating bias from method performance, effects of the sample matrix, and (or) analyte degradation generally is small but is more likely to be slightly negative than positive. No HHBs exist that are specific to individual arsenic species, although there is an HHB for total arsenic.

Table 5.6. Summary of results for spike samples collected by the National Water-Quality Assessment Project from May 2013 to December 2018.

[VOC, volatile organic compound; HHB, human-health benchmark; --, not applicable]

\begin{tabular}{|c|c|c|c|c|c|}
\hline Type of summary & $\begin{array}{l}\text { VOCs by } \\
\text { schedule } \\
4436\end{array}$ & $\begin{array}{l}\text { VOCs by schedule } \\
4437\end{array}$ & $\begin{array}{l}\text { Trace } \\
\text { elements }\end{array}$ & Arsenic species & $\begin{array}{l}\text { Microbiological } \\
\text { constituents }^{2}\end{array}$ \\
\hline Total number of field spikes & 0 & 0 & 0 & 12 & 0 \\
\hline Total number of laboratory spikes & 135 & 138 & 29 & 0 & 25 \\
\hline Number of constituents analyzed & 49 & 37 & 21 & 4 & 2 \\
\hline $\begin{array}{l}\text { Range of median spike recoveries } \\
\text { (in percent) }\end{array}$ & $72.6-110.9$ & $86.5-107.8$ & $82.5-111.5$ & $86.5-91.3$ & Presence confirmed ${ }^{3}$ \\
\hline $\begin{array}{l}\text { Number of compounds with } \\
\text { median spike recovery less than } \\
70 \text { percent }\end{array}$ & 0 & 0 & 0 & 0 & -- \\
\hline $\begin{array}{l}\text { Number of compounds with } \\
\text { median spike recovery less than } \\
70 \text { percent with a correspond- } \\
\text { ing HHB }\end{array}$ & -- & -- & -- & -- & -- \\
\hline $\begin{array}{l}\text { Number of compounds with } \\
\text { median spike recovery greater } \\
\text { than } 130 \text { percent with a cor- } \\
\text { responding HHB }\end{array}$ & -- & -- & -- & -- & -- \\
\hline
\end{tabular}

${ }_{1}^{1}$ Results for silver were not included in this analysis because the spike concentration was less than the laboratory reporting level of 1 microgram per liter.

2Results for microbiological constituents are for January 2016 to December 2018.

${ }^{3}$ Coliphage spike results indicate presence or absence rather than a concentration; coliphage presence was confirmed in all 34 samples. 


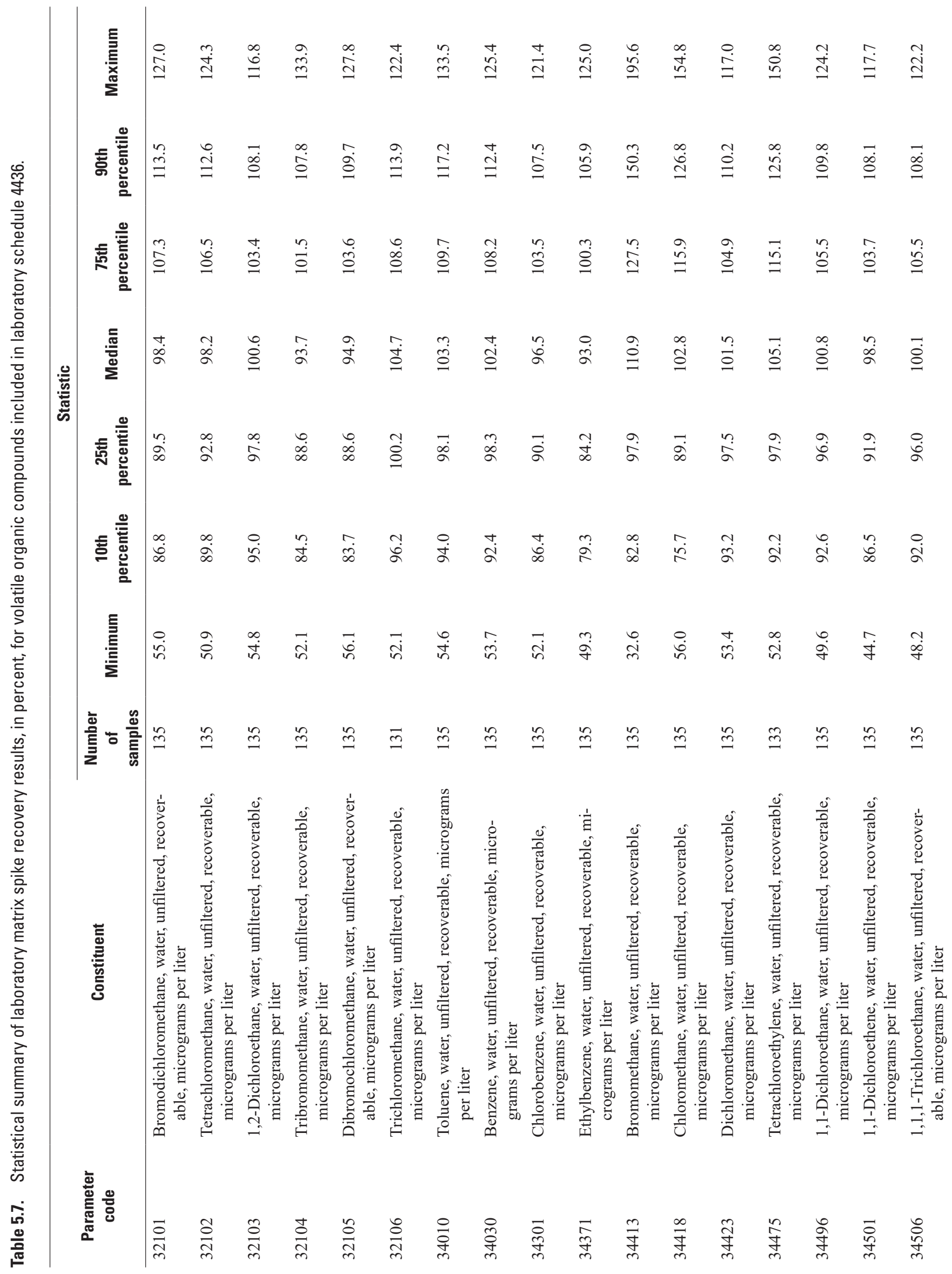




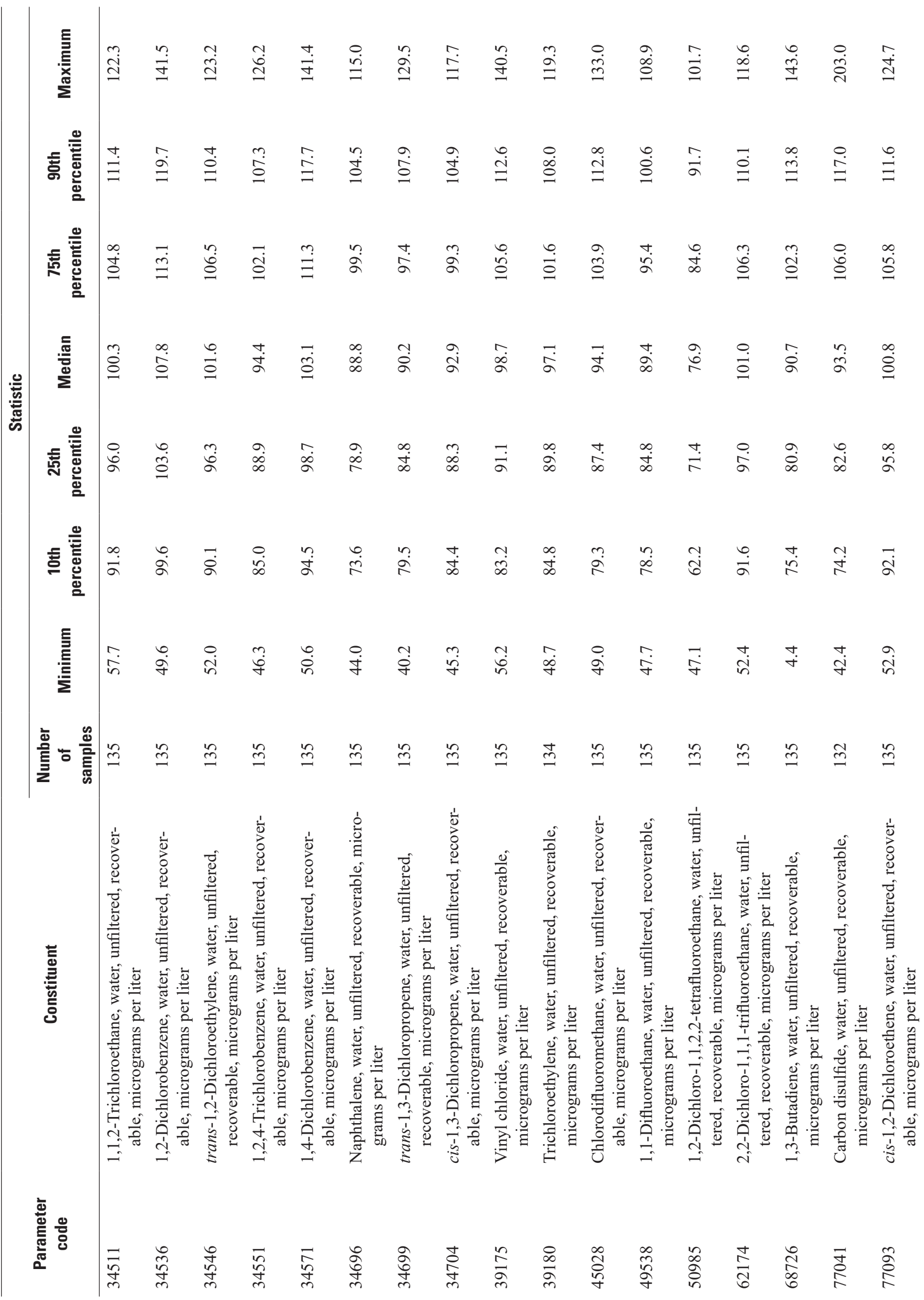




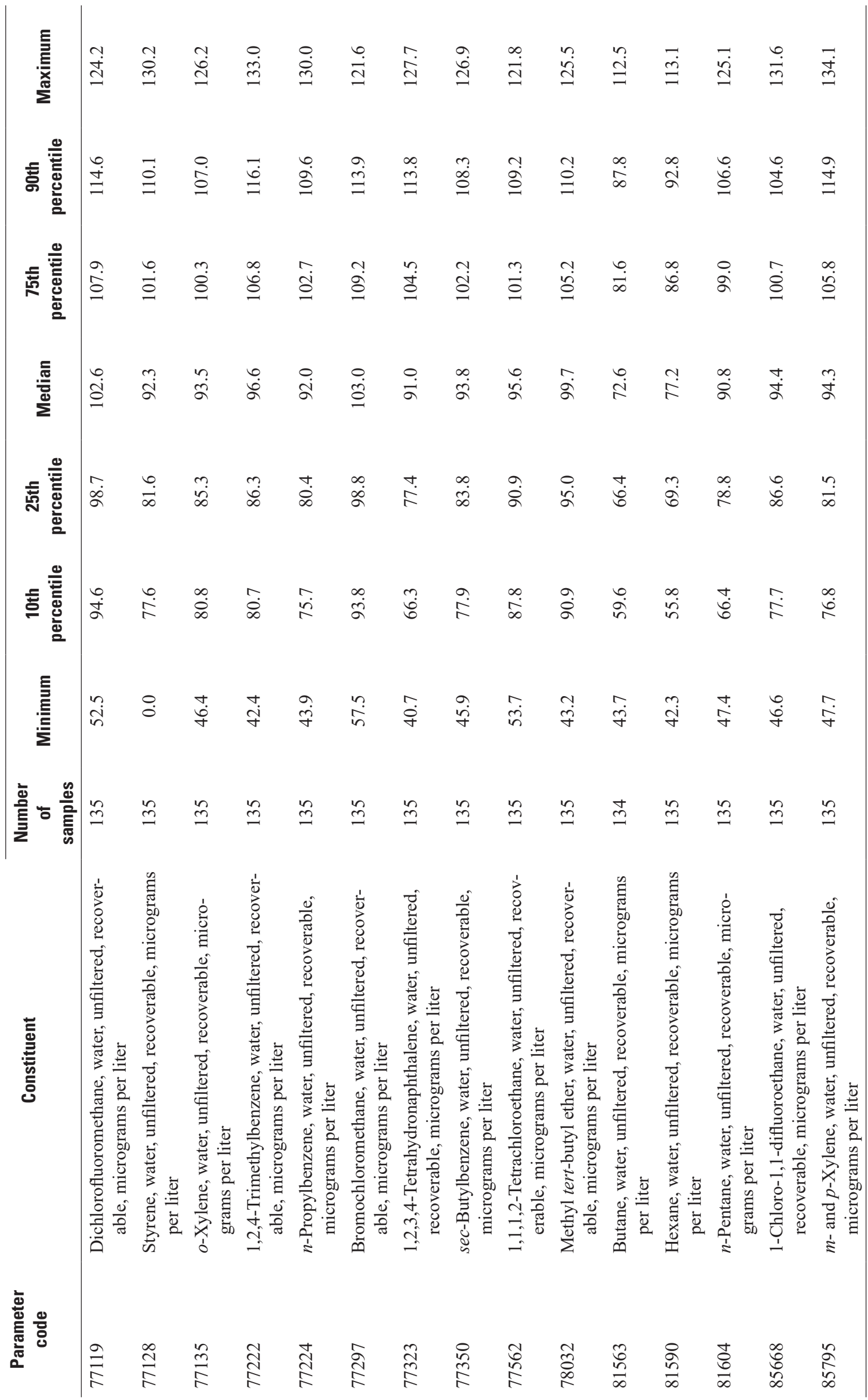


Table 5.8. Statistical summary of laboratory matrix spike recovery results, in percent, for volatile organic compounds included in laboratory schedule 4437.

\begin{tabular}{|c|c|c|c|c|c|c|c|c|c|}
\hline \multirow[b]{2}{*}{$\begin{array}{l}\text { Parameter } \\
\text { code }\end{array}$} & \multirow[b]{2}{*}{ Constituent } & \multicolumn{8}{|c|}{ Statistic } \\
\hline & & $\begin{array}{l}\text { Number } \\
\text { of } \\
\text { samples }\end{array}$ & Minimum & $\begin{array}{c}\text { 10th } \\
\text { percentile }\end{array}$ & $\begin{array}{c}\text { 25th } \\
\text { percentile }\end{array}$ & Median & $\begin{array}{c}\text { 75th } \\
\text { percentile }\end{array}$ & $\begin{array}{c}\text { 90th } \\
\text { percentile }\end{array}$ & Maximum \\
\hline 34386 & $\begin{array}{l}\text { Hexachlorocyclopentadiene, water, } \\
\text { unfiltered, recoverable, micro- } \\
\text { grams per liter }\end{array}$ & 34 & 58.7 & 79.4 & 84.8 & 92.7 & 114.5 & 122.7 & 149.8 \\
\hline 34408 & $\begin{array}{l}\text { Isophorone, water, unfiltered, re- } \\
\text { coverable, micrograms per liter }\end{array}$ & 138 & 0.0 & 72.6 & 83.3 & 96.1 & 111.6 & 128.0 & 137.8 \\
\hline 34447 & $\begin{array}{l}\text { Nitrobenzene, water, unfiltered, } \\
\text { recoverable, micrograms per liter }\end{array}$ & 138 & 40.9 & 76.7 & 85.3 & 91.9 & 101.8 & 117.6 & 133.6 \\
\hline 34541 & $\begin{array}{l}\text { 1,2-Dichloropropane, water, unfil- } \\
\text { tered, recoverable, micrograms } \\
\text { per liter }\end{array}$ & 138 & 68.9 & 91.8 & 96.8 & 100.2 & 104.0 & 108.0 & 120.4 \\
\hline 45013 & $\begin{array}{l}\text { Acetate, isopropyl, water, unfil- } \\
\text { tered, recoverable, micrograms } \\
\text { per liter }\end{array}$ & 138 & 67.6 & 92.9 & 96.7 & 102.4 & 106.5 & 112.6 & 125.4 \\
\hline 45022 & $\begin{array}{l}\text { Acetate, propyl, water, unfiltered, } \\
\text { recoverable, micrograms per liter }\end{array}$ & 138 & 51.8 & 84.4 & 88.3 & 93.6 & 99.0 & 105.6 & 118.2 \\
\hline 68066 & $\begin{array}{l}\text { 1-Methoxy-4-(2-propenyl) ben- } \\
\text { zene, water, unfiltered, recover- } \\
\text { able, micrograms per liter }\end{array}$ & 138 & 0.0 & 72.7 & 80.1 & 86.5 & 96.8 & 110.6 & 130.0 \\
\hline 68728 & $\begin{array}{l}\text { 2-Ethoxyethyl acetate, water, unfil- } \\
\text { tered, recoverable, micrograms } \\
\text { per liter }\end{array}$ & 138 & 63.1 & 81.9 & 95.4 & 106.3 & 118.8 & 125.6 & 138.1 \\
\hline 68729 & $\begin{array}{l}\text { 2-Propen-1-ol, water, unfiltered, } \\
\text { recoverable, micrograms per liter }\end{array}$ & 138 & 0.0 & 86.7 & 95.3 & 103.2 & 113.0 & 118.0 & 137.2 \\
\hline 68730 & $\begin{array}{l}\text { alpha-Terpineol, water, unfiltered, } \\
\text { recoverable, micrograms per liter }\end{array}$ & 138 & 0.0 & 71.5 & 79.1 & 89.8 & 105.3 & 122.9 & 145.1 \\
\hline 68732 & $\begin{array}{l}\text { Butanal, water, unfiltered, recover- } \\
\text { able, micrograms per liter }\end{array}$ & 138 & 69.3 & 88.1 & 91.5 & 98.1 & 105.2 & 113.8 & 126.6 \\
\hline 68733 & $\begin{array}{l}\text { trans-Crotonaldehyde, water, unfil- } \\
\text { tered, recoverable, micrograms } \\
\text { per liter }\end{array}$ & 138 & 0.0 & 88.1 & 93.0 & 97.9 & 101.8 & 108.5 & 118.7 \\
\hline 76997 & $\begin{array}{l}\text { Acetonitrile, water, unfiltered, re- } \\
\text { coverable, micrograms per liter }\end{array}$ & 138 & 47.2 & 90.9 & 99.6 & 107.8 & 118.0 & 124.8 & 142.4 \\
\hline 77015 & $\begin{array}{l}\text { Isopropyl alcohol, water, unfiltered, } \\
\text { recoverable, micrograms per liter }\end{array}$ & 138 & 64.9 & 86.1 & 90.2 & 95.3 & 101.5 & 110.9 & 332.4 \\
\hline 77032 & $\begin{array}{l}\text { Methyl acetate, water, unfiltered, } \\
\text { recoverable, micrograms per liter }\end{array}$ & 138 & 58.1 & 89.8 & 94.9 & 101.6 & 108.2 & 116.7 & 132.0 \\
\hline 77034 & $\begin{array}{l}\text { Butanol, water, unfiltered, recover- } \\
\text { able, micrograms per liter }\end{array}$ & 138 & 62.0 & 87.3 & 93.9 & 98.9 & 105.2 & 111.2 & 120.8 \\
\hline 77035 & $\begin{array}{l}\text { tert-Butyl alcohol, water, unfil- } \\
\text { tered, recoverable, micrograms } \\
\text { per liter }\end{array}$ & 138 & 64.9 & 94.0 & 96.1 & 99.6 & 104.2 & 111.5 & 119.6 \\
\hline 77061 & $\begin{array}{l}n \text {-Pentanal, water, unfiltered, recov- } \\
\text { erable, micrograms per liter }\end{array}$ & 138 & 63.9 & 85.3 & 88.9 & 93.6 & 98.5 & 107.0 & 120.3 \\
\hline 77076 & $\begin{array}{l}\text { 2-Nitropropane, water, unfiltered, } \\
\text { recoverable, micrograms per liter }\end{array}$ & 138 & 64.1 & 89.4 & 93.9 & 97.8 & 102.1 & 106.3 & 117.4 \\
\hline 77097 & $\begin{array}{l}\text { Cyclohexanone, water, unfiltered, } \\
\text { recoverable, micrograms per liter }\end{array}$ & 138 & 64.8 & 86.4 & 91.5 & 97.1 & 104.2 & 111.2 & 168.3 \\
\hline
\end{tabular}


Table 5.8. Statistical summary of laboratory matrix spike recovery results, in percent, for volatile organic compounds included in laboratory schedule 4437.-Continued

\begin{tabular}{|c|c|c|c|c|c|c|c|c|c|}
\hline \multirow[b]{2}{*}{$\begin{array}{l}\text { Parameter } \\
\text { code }\end{array}$} & \multirow[b]{2}{*}{ Constituent } & \multicolumn{8}{|c|}{ Statistic } \\
\hline & & $\begin{array}{c}\text { Number } \\
\text { of } \\
\text { samples }\end{array}$ & Minimum & $\begin{array}{c}\text { 10th } \\
\text { percentile }\end{array}$ & $\begin{array}{c}\text { 25th } \\
\text { percentile }\end{array}$ & Median & $\begin{array}{c}\text { 75th } \\
\text { percentile }\end{array}$ & $\begin{array}{c}\text { 90th } \\
\text { percentile }\end{array}$ & Maximum \\
\hline 77113 & $\begin{array}{l}\text { 2-pentanol, 4-methyl-, water, unfil- } \\
\text { tered, recoverable, micrograms } \\
\text { per liter }\end{array}$ & 138 & 60.1 & 88.6 & 93.1 & 97.2 & 101.1 & 104.3 & 114.4 \\
\hline 77179 & $\begin{array}{l}\text { 2-hexanone, 5-methyl-, water, un- } \\
\text { filtered, recoverable, micrograms } \\
\text { per liter }\end{array}$ & 138 & 60.7 & 88.6 & 93.1 & 99.8 & 105.8 & 110.1 & 128.4 \\
\hline 77201 & $\begin{array}{l}\text { Acetate, isobutyl, water, unfiltered, } \\
\text { recoverable, micrograms per liter }\end{array}$ & 138 & 58.1 & 80.0 & 84.3 & 88.3 & 93.6 & 97.8 & 109.1 \\
\hline 77310 & $\begin{array}{l}\text { 1-Octanol, water, unfiltered, recov- } \\
\text { erable, micrograms per liter }\end{array}$ & 138 & 56.5 & 79.7 & 84.6 & 89.7 & 95.2 & 104.0 & 115.7 \\
\hline 77311 & $\begin{array}{l}\text { Hexanol, 2-ethyl-, water, unfiltered, } \\
\text { recoverable, micrograms per liter }\end{array}$ & 138 & 51.6 & 78.1 & 82.0 & 88.0 & 94.8 & 102.2 & 116.7 \\
\hline 77419 & $\begin{array}{l}\text { 4-heptanone, 2,6-dimethyl-, water, } \\
\text { unfiltered, recoverable, micro- } \\
\text { grams per liter }\end{array}$ & 138 & 53.8 & 81.7 & 85.3 & 91.4 & 99.4 & 108.3 & 132.1 \\
\hline 77443 & $\begin{array}{l}\text { 1,2,3-Trichloropropane, water, un- } \\
\text { filtered, recoverable, micrograms } \\
\text { per liter }\end{array}$ & 137 & 64.1 & 92.2 & 96.6 & 99.0 & 102.7 & 107.1 & 117.2 \\
\hline 77548 & $\begin{array}{l}\text { Chloropicrin, water, unfiltered, } \\
\text { recoverable, micrograms per liter }\end{array}$ & 138 & 15.1 & 82.5 & 93.4 & 103.5 & 114.7 & 124.0 & 198.1 \\
\hline 77651 & $\begin{array}{l}\text { 1,2-Dibromoethane, water, unfil- } \\
\text { tered, recoverable, micrograms } \\
\text { per liter }\end{array}$ & 138 & 64.0 & 92.7 & 96.3 & 99.2 & 103.3 & 106.9 & 120.4 \\
\hline 78032 & $\begin{array}{l}\text { Methyl tert-butyl ether, water, un- } \\
\text { filtered, recoverable, micrograms } \\
\text { per liter }\end{array}$ & 138 & 67.4 & 93.8 & 98.0 & 102.1 & 106.7 & 111.9 & 173.4 \\
\hline 78200 & $\begin{array}{l}\text { Diethylamine, N nitroso-, water, } \\
\text { unfiltered, recoverable, micro- } \\
\text { grams per liter }\end{array}$ & 138 & 65.2 & 81.1 & 88.5 & 101.9 & 114.2 & 126.0 & 143.8 \\
\hline 80336 & $\begin{array}{l}\text { 1,1-Dichloro-2-propanone, water, } \\
\text { unfiltered, recoverable, micro- } \\
\text { grams per liter }\end{array}$ & 138 & 61.5 & 90.0 & 96.1 & 104.2 & 109.3 & 114.4 & 138.7 \\
\hline 81578 & $\begin{array}{l}\text { Dimethoxymethane, water, unfil- } \\
\text { tered, recoverable, micrograms } \\
\text { per liter }\end{array}$ & 138 & 71.5 & 95.5 & 100.2 & 104.6 & 110.8 & 115.7 & 127.7 \\
\hline 81582 & $\begin{array}{l}\text { 1,4-Dioxane, water, unfiltered, } \\
\text { recoverable, micrograms per liter }\end{array}$ & 138 & 28.0 & 87.3 & 92.7 & 96.2 & 100.7 & 104.5 & 114.5 \\
\hline 81583 & $\begin{array}{l}\text { 1,3-Dioxolane, water, unfiltered, } \\
\text { recoverable, micrograms per liter }\end{array}$ & 138 & 61.5 & 86.8 & 95.3 & 101.8 & 107.7 & 113.3 & 131.0 \\
\hline 81585 & $\begin{array}{l}\text { Acetate, ethyl, water, unfiltered, } \\
\text { recoverable, micrograms per liter }\end{array}$ & 138 & 60.7 & 86.2 & 92.4 & 100.3 & 106.3 & 110.6 & 125.8 \\
\hline 82625 & $\begin{array}{l}\text { 1,2-Dibromo-3-chloropropane, } \\
\text { water, unfiltered, recoverable, } \\
\text { micrograms per liter }\end{array}$ & 136 & 61.3 & 86.1 & 91.8 & 96.3 & 101.4 & 108.0 & 122.4 \\
\hline
\end{tabular}



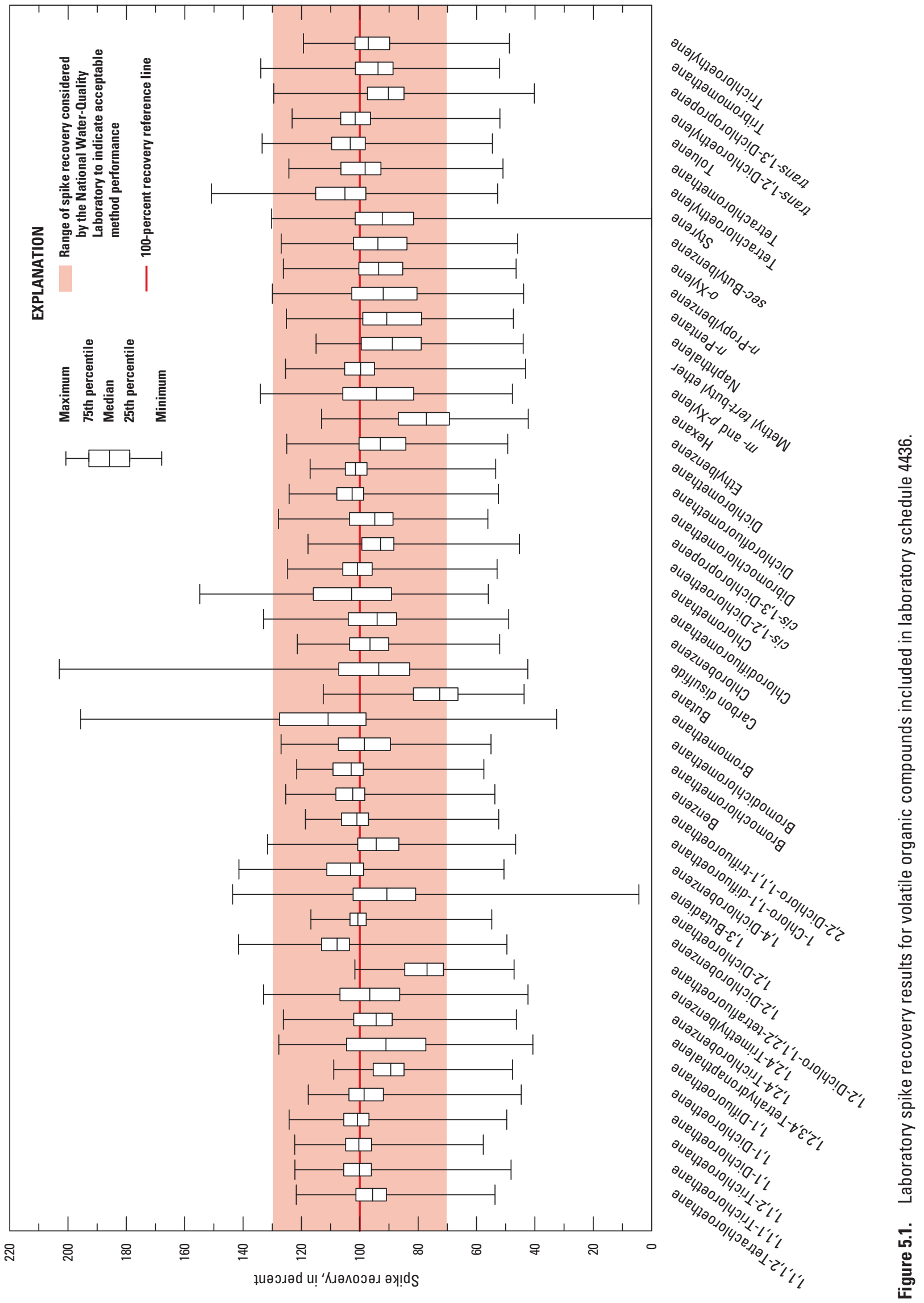

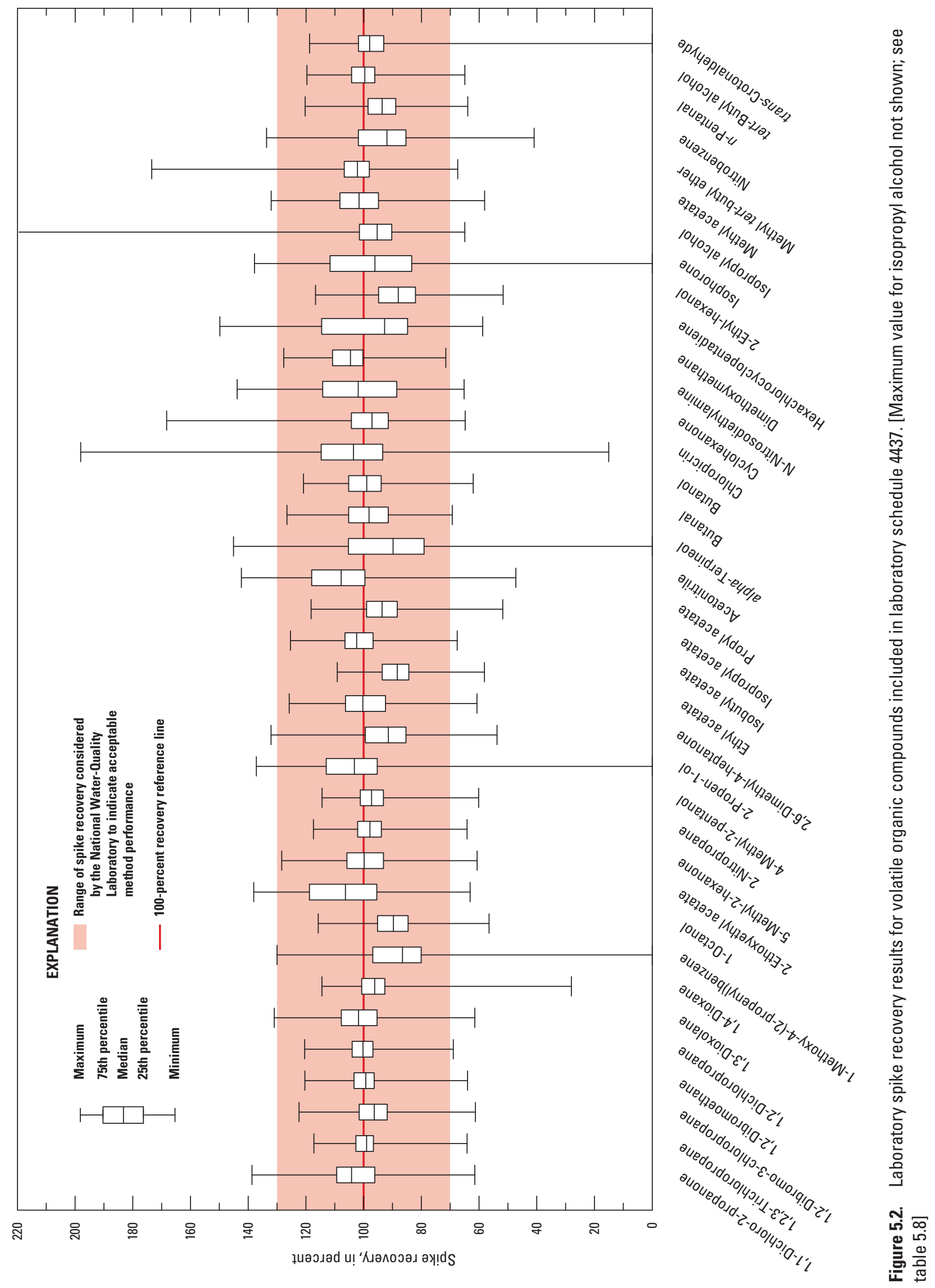
Table 5.9. Statistical summary of laboratory matrix spike recovery results for trace elements included in laboratory schedule 2710.

\begin{tabular}{|c|c|c|c|c|c|c|c|c|c|}
\hline \multirow{2}{*}{$\begin{array}{l}\text { Parameter } \\
\text { code }\end{array}$} & \multirow[b]{2}{*}{ Constituent } & \multicolumn{8}{|c|}{ Statistic } \\
\hline & & $\begin{array}{c}\text { Number of } \\
\text { samples }\end{array}$ & Minimum & $\begin{array}{c}\text { 10th } \\
\text { percentile }\end{array}$ & $\begin{array}{c}\text { 25th } \\
\text { percentile }\end{array}$ & Median & $\begin{array}{c}\text { 75th } \\
\text { percentile }\end{array}$ & $\begin{array}{c}\text { 90th } \\
\text { percentile }\end{array}$ & Maximum \\
\hline 01000 & $\begin{array}{l}\text { Arsenic, water, filtered, } \\
\text { micrograms per liter }\end{array}$ & 20 & 11.6 & 91.4 & 98.6 & 104.1 & 111.3 & 114.3 & 121.6 \\
\hline 01005 & $\begin{array}{l}\text { Barium, water, filtered, } \\
\text { micrograms per liter }\end{array}$ & 18 & 85.8 & 86.9 & 93.6 & 96.3 & 98.9 & 103.8 & 108.7 \\
\hline 01010 & $\begin{array}{l}\text { Beryllium, water, filtered, } \\
\text { micrograms per liter }\end{array}$ & 24 & 71.8 & 83.9 & 86.0 & 93.8 & 98.7 & 102.2 & 112.9 \\
\hline 01020 & $\begin{array}{l}\text { Boron, water, filtered, } \\
\text { micrograms per liter }\end{array}$ & 23 & 37.6 & 72.3 & 81.3 & 87.9 & 94.1 & 104.4 & 113.3 \\
\hline 01025 & $\begin{array}{l}\text { Cadmium, water, filtered, } \\
\text { micrograms per liter }\end{array}$ & 29 & 50.4 & 91.6 & 100.1 & 104.0 & 108.7 & 112.3 & 120.1 \\
\hline 01030 & $\begin{array}{l}\text { Chromium, water, filtered, } \\
\text { micrograms per liter }\end{array}$ & 25 & 50.7 & 79.0 & 91.8 & 106.7 & 110.1 & 117.7 & 120.0 \\
\hline 01035 & $\begin{array}{l}\text { Cobalt, water, filtered, } \\
\text { micrograms per liter }\end{array}$ & 22 & 87.8 & 90.0 & 93.3 & 96.6 & 105.2 & 107.1 & 116.2 \\
\hline 01040 & $\begin{array}{l}\text { Copper, water, filtered, } \\
\text { micrograms per liter }\end{array}$ & 23 & 55.9 & 90.0 & 92.2 & 97.5 & 101.2 & 107.8 & 110.0 \\
\hline 01049 & $\begin{array}{l}\text { Lead, water, filtered, mi- } \\
\text { crograms per liter }\end{array}$ & 25 & 49.2 & 84.6 & 87.6 & 93.4 & 97.0 & 99.8 & 105.8 \\
\hline 01056 & $\begin{array}{l}\text { Manganese, water, filtered, } \\
\text { micrograms per liter }\end{array}$ & 24 & 83.4 & 87.6 & 91.3 & 95.1 & 98.4 & 106.2 & 112.5 \\
\hline 01057 & $\begin{array}{l}\text { Thallium, water, filtered, } \\
\text { micrograms per liter }\end{array}$ & 29 & 0.0 & 73.2 & 80.4 & 82.5 & 87.2 & 96.3 & 107.5 \\
\hline 01060 & $\begin{array}{l}\text { Molybdenum, water, } \\
\text { filtered, micrograms per } \\
\text { liter }\end{array}$ & 20 & 68.9 & 97.5 & 103.4 & 111.5 & 115.5 & 116.9 & 120.8 \\
\hline 01065 & $\begin{array}{l}\text { Nickel, water, filtered, } \\
\text { micrograms per liter }\end{array}$ & 20 & 80.1 & 89.5 & 94.0 & 101.2 & 105.8 & 111.0 & 113.9 \\
\hline 01080 & $\begin{array}{l}\text { Strontium, water, filtered, } \\
\text { micrograms per liter }\end{array}$ & 9 & 93.2 & 93.2 & 103.6 & 106.8 & 107.9 & 112.9 & 112.9 \\
\hline 01085 & $\begin{array}{l}\text { Vanadium, water, filtered, } \\
\text { micrograms per liter }\end{array}$ & 24 & 90.0 & 90.9 & 97.5 & 103.2 & 107.5 & 109.3 & 116.1 \\
\hline 01090 & $\begin{array}{l}\text { Zinc, water, filtered, micro- } \\
\text { grams per liter }\end{array}$ & 20 & 12.8 & 93.4 & 97.4 & 106.5 & 118.2 & 124.0 & 141.6 \\
\hline 01095 & $\begin{array}{l}\text { Antimony, water, filtered, } \\
\text { micrograms per liter }\end{array}$ & 29 & 86.1 & 91.2 & 98.4 & 101.6 & 106.9 & 116.6 & 119.3 \\
\hline 01106 & $\begin{array}{l}\text { Aluminum, water, filtered, } \\
\text { micrograms per liter }\end{array}$ & 25 & 72.6 & 78.9 & 87.6 & 94.1 & 99.3 & 104.0 & 127.1 \\
\hline 01130 & $\begin{array}{l}\text { Lithium, water, filtered, } \\
\text { micrograms per liter }\end{array}$ & 20 & 45.6 & 78.4 & 82.4 & 89.3 & 96.2 & 108.9 & 111.9 \\
\hline 01145 & $\begin{array}{l}\text { Selenium, water, filtered, } \\
\text { micrograms per liter }\end{array}$ & 22 & 86.1 & 96.6 & 103.8 & 110.6 & 115.0 & 118.5 & 122.5 \\
\hline 22703 & $\begin{array}{l}\text { Uranium (natural), water, } \\
\text { filtered, micrograms per } \\
\text { liter }\end{array}$ & 23 & 87.9 & 90.7 & 94.6 & 100.0 & 105.9 & 107.1 & 122.0 \\
\hline
\end{tabular}




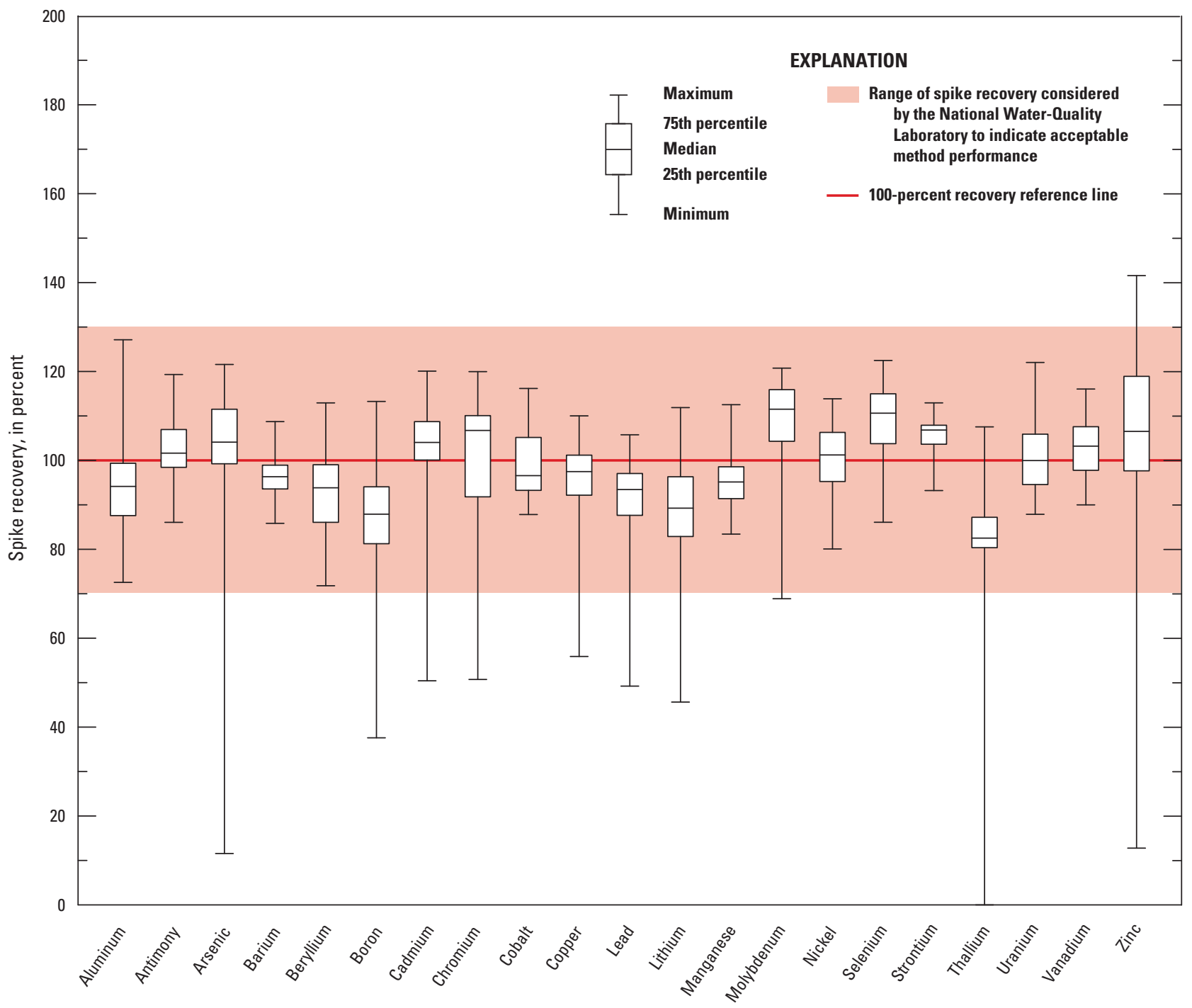

Figure 5.3. Boxplots of laboratory spike recovery results for trace elements included in laboratory schedule 2710. 
Table 5.10. Statistical summary of field matrix spike recovery results for arsenic species analyzed under laboratory code 3142 .

\begin{tabular}{|c|c|c|c|c|c|c|c|c|c|}
\hline \multirow[b]{2}{*}{$\begin{array}{l}\text { Parameter } \\
\text { code }\end{array}$} & \multirow[b]{2}{*}{ Constituent } & \multicolumn{8}{|c|}{ Statistic } \\
\hline & & $\begin{array}{l}\text { Number } \\
\text { of } \\
\text { samples }\end{array}$ & Minimum & $\begin{array}{c}\text { 10th } \\
\text { percentile }\end{array}$ & $\begin{array}{c}\text { 25th } \\
\text { percentile }\end{array}$ & Median & $\begin{array}{c}\text { 75th } \\
\text { percentile }\end{array}$ & $\begin{array}{c}\text { 90th } \\
\text { percentile }\end{array}$ & Maximum \\
\hline 62453 & $\begin{array}{l}\text { Arsenate, water, filtered, } \\
\text { micrograms per liter as } \\
\text { arsenic }\end{array}$ & 9 & 77.3 & 84.6 & 86.7 & 90.0 & 101.1 & 109.4 & 124.7 \\
\hline 62452 & $\begin{array}{l}\text { Arsenite, water, filtered, } \\
\text { micrograms per liter as } \\
\text { arsenic }\end{array}$ & 11 & 60.6 & 83.7 & 85.6 & 91.3 & 107.5 & 110.9 & 111.2 \\
\hline 62455 & $\begin{array}{l}\text { Dimethylarsinate, water, } \\
\text { filtered, recoverable, } \\
\text { micrograms per liter as } \\
\text { arsenic }\end{array}$ & 12 & 0.0 & 64.2 & 82.9 & 90.0 & 93.9 & 98.7 & 100.0 \\
\hline 62454 & $\begin{array}{l}\text { Monomethylarsonate, water, } \\
\text { filtered, recoverable, } \\
\text { micrograms per liter as } \\
\text { arsenic }\end{array}$ & 12 & 70.6 & 81.7 & 83.1 & 86.5 & 97.5 & 102.9 & 107.1 \\
\hline
\end{tabular}

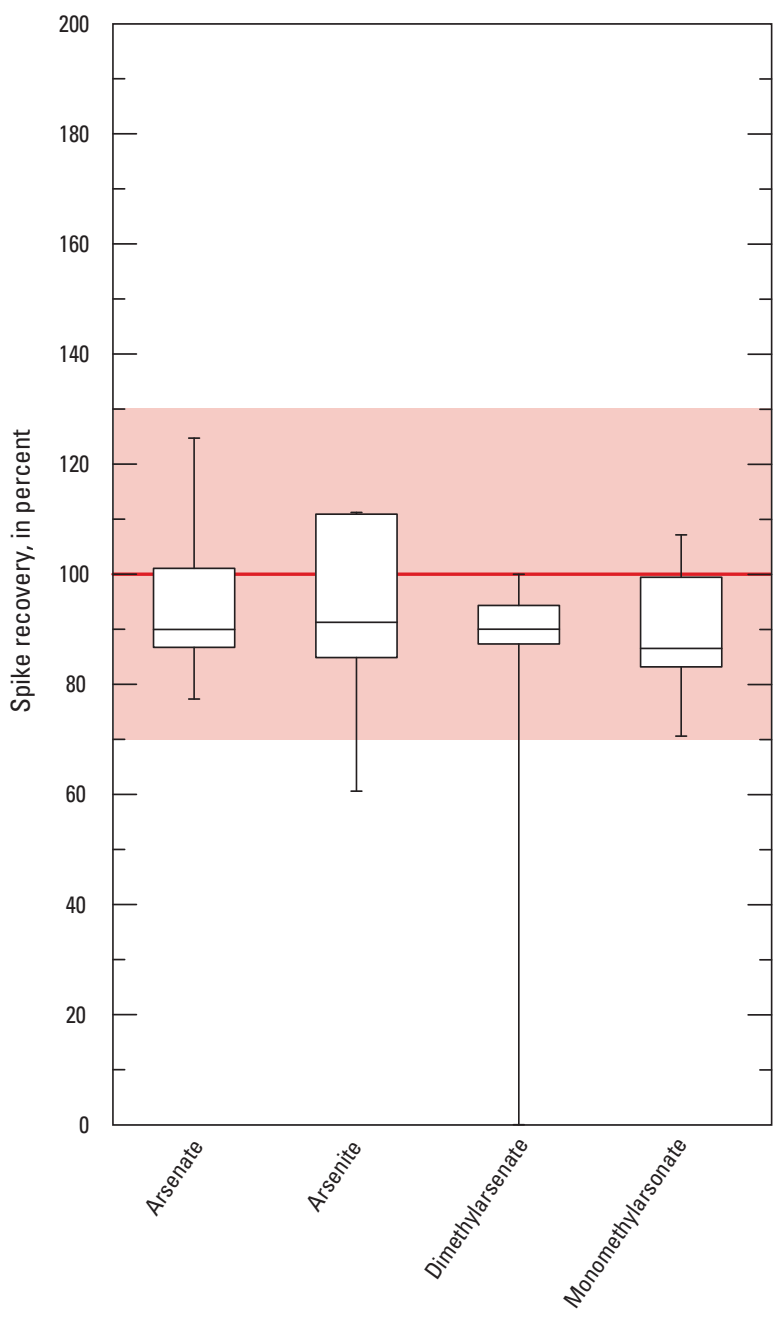

EXPLANATION

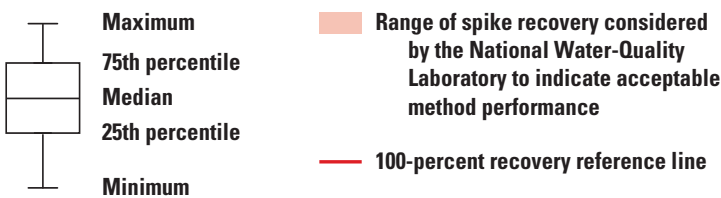

Figure 5.4. Boxplots of field spike recovery results for arsenic speciation by laboratory code 3142. 


\section{References Cited}

Arnold, T.L., Bexfield, L.M., Musgrove, M., Erickson, M.L., Kingsbury, J.A., Degnan, J.R., Tesoriero, A.J., Kulongoski, J.T., and Belitz, K., 2020a, Groundwater-quality and select quality-control data from the National Water-Quality Assessment Project, January through December 2016, and previously unpublished data from 2013 to 2015: U.S. Geological Survey Data Series 1124, 135 p., accessed June 2020 at https://doi.org/10.3133/ds1124.

Arnold, T.L., Bexfield, L.M., Musgrove, M., Stackelberg, P.E., Lindsey, B.D., Barlow, J.R., Kulongoski, J.T., and Belitz, K., 2018a, Datasets from groundwater-quality and select quality-control data from the National Water-Quality Assessment Project, January through December 2015 and previously unpublished data from 2013-2014: U.S. Geological Survey data release, accessed September 4, 2019, at https://doi.org/10.5066/F7XK8DHK.

Arnold, T.L., Bexfield, L.M., Musgrove, M., Stackelberg, P.E., Lindsey, B.D., Kingsbury, J.A., Kulongoski, J.T., and Belitz, K., 2018b, Groundwater-quality and select qualitycontrol data from the National Water-Quality Assessment Project, January through December 2015, and previously unpublished data from 2013 to 2014: U.S. Geological Survey Data Series 1087, 67 p., accessed January 2020 at https://doi.org/10.3133/ds1087.

Arnold, T.L., Bexfield, L.M., Musgrove, M., Lindsey, B.D., Stackelberg, P.E., Barlow, J.R., DeSimone, L.A., Kulongoski, J.T., Kingsbury, J.A., Ayotte, J.D., Fleming, B.J., and Belitz, K., 2017a, Datasets from groundwaterquality data from the National Water-Quality Assessment Project, January through December 2014 and select qualitycontrol data from May 2012 through December 2014: U.S. Geological Survey data release, accessed March 28, 2018, at https://doi.org/10.5066/F7W0942N.

Arnold, T.L., Bexfield, L.M., Musgrove, M., Lindsey, B.D., Stackelberg, P.E., Barlow, J.R., DeSimone, L.A., Kulongoski, J.T., Kingsbury, J.A., Ayotte, J.D., Fleming, B.J., and Belitz, K., 2017b, Groundwater-quality data from the National Water-Quality Assessment Project, January through December 2014 and select quality-control data from May 2012 through December 2014: U.S. Geological Survey Data Series 1063, 83 p., accessed March 28, 2018, at https://doi.org/10.3133/ds1063.

Arnold, T.L., DeSimone, L.A., Bexfield, L.M., Lindsey, B.D., Barlow, J.R., Kulongoski, J.T., Musgrove, M., Kingsbury, J.A., and Belitz, K., 2016a, Groundwater quality data from the National Water Quality Assessment Project, May 2012 through December 2013: U.S. Geological Survey data release, accessed March 28, 2018, at https://doi.org/ 10.5066/F7HQ3X18.
Arnold, T.L., DeSimone, L.A., Bexfield, L.M., Lindsey, B.D., Barlow, J.R., Kulongoski, J.T., Musgrove, M., Kingsbury, J.A., and Belitz, K., 2016b, Groundwater quality data from the National Water-Quality Assessment Project, May 2012 through December 2013: U.S. Geological Survey Data Series 997, 56 p., accessed March 28, 2018, at https://doi.org/10.3133/ds997.

Arnold, T.L., Sharpe, J.B., Bexfield, L.M., Musgrove, M., Erickson, M.L., Kingsbury, J.A., Degnan, J.R., Tesoriero, A.J., Kulongoski, J.T., and Belitz, K., 2020b, Datasets from groundwater-quality and select quality-control data from the National Water-Quality Assessment Project, January through December 2016 and previously unpublished data from 2013-2015: U.S. Geological Survey data release, https://doi.org/10.5066/P9W4RR74.

Bender, D.A., Zogorski, J.S., Mueller, D.K., Rose, D.L., Martin, J.D., and Brenner, C.K., 2011, Quality of volatile organic compound data from groundwater and surface water for the National Water-Quality Assessment Program, October 1996-December 2008: U.S. Geological Survey Scientific Investigations Report 2011-5204, 128 p., accessed January 4, 2016, at https://doi.org/10.3133/ sir20115204.

Bexfield, L.M., Belitz, K., Sandstrom, M.W., Beaty, D., Medalie, L., Lindsey, B.D., and Nowell, L.H., 2020, Quality of pesticide data for groundwater analyzed for the National Water-Quality Assessment Project, 2013-18: U.S. Geological Survey Scientific-Investigations Report 2020-5072, 35 p., accessed September 2020 at https://doi.org/10.3133/sir20205072.

Davis, T.A., Olsen, L.D., Fram, M.S., and Belitz, K., 2014, Updated study reporting levels (SRLs) for trace-element data collected for the California Groundwater Ambient Monitoring and Assessment (GAMA) Priority Basin Project, October 2009-March 2013: U.S. Geological Survey Scientific Investigations Report 2014-5105, 52 p., accessed January 4, 2016, at https://doi.org/10.3133/sir20145105.

Fram, M.S., Olsen, L.D., and Belitz, K., 2012, Evaluation of volatile organic compound (VOC) blank data and application of study reporting levels to groundwater data collected for the California GAMA Priority Basin Project, May 2004 through September 2010: U.S. Geological Survey Scientific Investigations Report 2012-5139, 94 p., accessed January 4, 2016, at https://doi.org/10.3133/sir20125139.

Gilliom, R.J., Barbash, J.E., Crawford, C.G., Hamilton, P.A., and Martin, J.D., Nakagaki, N., Nowell, L.H., Scott, J.C., Stackelberg, P.E., Thelin, G.P., and Wolock, D.M., 2006, The quality of our Nation's waters-Pesticides in the Nation's streams and ground water, 1992-2001: U.S. Geological Survey Circular 1291, 172 p., accessed August 9, 2017, at https://doi.org/10.3133/cir1291. 
Kingsbury, J.A., Sharpe, J.B., Bexfield, L.M., Arnold, T.L., Musgrove, M., Erickson, M.L., Degnan, J.R., Tesoriero, A.J., Lindsey, B.D., and Belitz, K., 2020, Datasets of groundwater-quality and select quality-control data from the National Water-Quality Assessment Project, January 2017 through December 2019 (ver. 1.1, January 2021): U.S. Geological Survey data release, https://doi.org/10.5066/ P9XATXV1.

Martin, J.D., 2002, Variability of pesticide detections and concentrations in field replicate water samples collected for the National Water-Quality Assessment Program, 1992-97: U.S. Geological Survey Water-Resources Investigations Report 2001-4178, 84 p., accessed June 30, 2016, at https://doi.org/10.3133/wri20014178.

Mueller, D.K., Schertz, T.L., Martin, J.D., and Sandstrom, M.W., 2015, Design, analysis, and interpretation of field quality-control data for water-sampling projects: U.S. Geological Survey Techniques and Methods, book 4, chap. C4, 54 p., accessed April 2020 at https://doi.org/10.3133/ tm4C4.

Mueller, D.K., and Titus, C.J., 2005, Quality of nutrient data from streams and ground water sampled during water years 1992-2001: U.S. Geological Survey Scientific Investigations Report 2005-5106, 27 p. [Also available at https://doi.org/10.3133/sir20055106.]

Olsen, L.D., Fram, M.S., and Belitz, K., 2010, Review of trace-element field-blank data collected for the California Groundwater Ambient Monitoring and Assessment (GAMA) Program, May 2004-January 2008: U.S. Geological Survey Scientific Investigations Report 2009-5220, 47 p., accessed January 4, 2016, at https://doi.org/10.3133/sir20095220.

Shoda, M.E., Nowell, L.H., Stone, W.W., Sandstrom, M.W., and Bexfield, L.M., 2018, Data analysis considerations for pesticides determined by National Water Quality Laboratory schedule 2437: U.S. Geological Survey Scientific Investigations Report 2018-5007, 458 p., accessed April 2020 at https://doi.org/10.3133/sir20185007.

U.S. Geological Survey, 2020, USGS water data for the Nation: U.S. Geological Survey National Water Information System database, accessed April 2, 2020, at https://doi.org/ 10.5066/F7P55KJN.

Zogorski, J.S., Carter, J.M., Ivahnenko, T., Lapham, W.W., Moran, M.J., Rowe, B.L., Squillace, P.J., and Toccalino, P.L., 2006, The quality of our Nation's waters - Volatile organic compounds in the Nation's ground water and drinking-water supply wells: U.S. Geological Survey Circular 1292, 101 p., accessed January 4, 2016, at https://doi.org/10.3133/cir1292. 

For more information about this publication, contact:

Director, USGS Lower Mississippi-Gulf Water Science Center 640 Grassmere Park Drive

Nashville, TN 37211

615-837-4799

For additional information, visit: https://www.usgs.gov/centers/ Img-water

Publishing support provided by the

Lafayette and Rolla Publishing Service Centers 


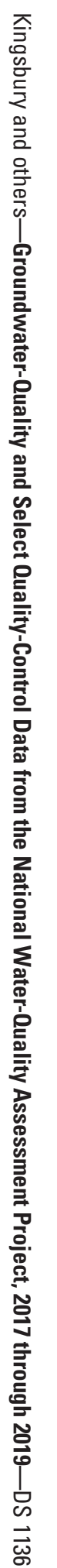

